FACULDADE DE FILOSOFIA, LETRAS E CIÊNCIAS HUMANAS DEPARTAMENTO DE TEORIA LITERÁRIA E LITERATURA COMPARADA

\title{
JUCIMARA TARRICONE
}

Hermenêutica e crítica: o pensamento e a obra de Benedito Nunes

São Paulo 
FACULDADE DE FILOSOFIA, LETRAS E CIÊNCIAS HUMANAS DEPARTAMENTO DE TEORIA LITERÁRIA E LITERATURA COMPARADA

JUCIMARA TARRICONE

Hermenêutica e crítica: o pensamento e a obra de Benedito Nunes

Tese apresentada à Banca Examinadora da Universidade de São Paulo, como exigência parcial para a obtenção do título de Doutora em Teoria Literária e Literatura Comparada.

Orientadora: Prof ${ }^{\mathrm{a}}$. Drª . Aurora Fornoni Bernardini

São Paulo 
FOLHA DE APROVAÇÃO

Jucimara Tarricone

Hermenêutica e crítica: o pensamento e a obra de Benedito Nunes

Tese apresentada à Banca Examinadora da Universidade de São Paulo, como exigência parcial para a obtenção do título de Doutora em Teoria Literária e Literatura Comparada.

Orientadora: Prof ${ }^{\mathrm{a}}$. Dr ${ }^{\mathrm{a}}$. Aurora Fornoni Bernardini

Aprovado em:

Banca Examinadora

Prof. Dr.

Instituição:

Assinatura:

Prof. Dr.

Instituição:

Assinatura:

Prof. Dr.

Instituição:

Assinatura:

Prof. Dr.

Instituição:

Assinatura:

Prof. Dr.

Instituição:

Assinatura: 


\section{AGRADECIMENTOS}

A realização desta tese contou com a ajuda de muitas pessoas. Agradeço, em especial, à Aurora Fornoni Bernardini pela orientação segura e pelo interesse com que acompanhou o percurso do trabalho;

ao casal Maria Sylvia e Benedito Nunes pela maneira acolhedora com que me receberam em Belém e ao Benedito Nunes, em particular, por permitir que pesquisasse em seus arquivos pessoais;

ao Danilo Adolfo Quincozes Morales e à Celeste Henrique Marques de Sousa pela leitura e sugestões precisas feitas no exame de qualificação;

ao Sílvio Augusto de Oliveira Holanda pela gentileza com que me cedeu importante material a respeito da obra de Benedito Nunes;

à Darcy Attanasio T. Ramos e à Elizabeth Rocha Leite pelo apoio, pelas leituras e sugestões e, principalmente, pela amizade com que compartilharam comigo esta caminhada;

ao Sérgio Roberto Montero Aguiar por sua leitura enriquecedora, pelas sugestões bibliográficas e pelo carinho demonstrado em todos estes anos;

à minha “família de Belém”: seu Elói, dona Edite, Andréa, Érica, Carla e Júnior - o amor supera a distância e os laços de sangue;

ao meu irmão Wilson Jr. por estar sempre ao meu lado.

Por fim, quero agradecer muito àqueles a quem devo um olhar mais poético da vida: minha mãe, Cecília Katy; minha irmã, Katia; e meu companheiro de amor, Cassiano Ricardo. 
DEDICATÓRIA

À Cecília Katy, à Katia e ao Cassiano.

Ao meu pai, sempre. 


\section{RESUMO}

TARRICONE, Jucimara. Hermenêutica e crítica: o pensamento e a obra de Benedito Nunes. Tese de Doutorado. Departamento de Teoria Literária e Literatura Comparada, Faculdade de Filosofia, Letras e Ciências Humanas, Universidade de São Paulo. São Paulo, 2007, 311 p.

Este estudo é, no essencial, uma reflexão acerca da produção, do método e da construção da linguagem crítica de Benedito Nunes. Tal crítica é entendida como uma leitura hermenêutica perpassada por um discurso em confrontação filosófica e literária, em que outras vozes, em vários momentos, misturam-se à sua identidade escritural, como as de Nietzsche, de Heidegger, de Ricoeur...

O que se pretende, antes de tudo, é acompanhar os passos da sua hermenêutica, realçar a problemática que ele imprime ao seu texto; qual seja, o repensar crítico das questões do Homem, do Mundo, em um ato de interpretação que, como lembra Foucault, enreda o próprio intérprete e o faz interpretar-se a si mesmo.

Assim, no primeiro capítulo, denominado "Uma incursão à obra e ao pensamento de Benedito Nunes”, a intenção foi a de ressaltar seus principais escritos, a recepção crítica à sua obra e a linha interpretativa em que se move.

O segundo, intitulado “A crítica crítico-reflexiva de Benedito Nunes”, foi dividido em quatro momentos representativos das preponderantes características do seu corpus ensaístico: 1. a crítica definida como tensão entre a escrita dos escritores e a leitura dos críticos; 2. o confronto de idéias estéticas e poéticas; 3. as raízes filosóficas como marcas do discurso teórico-crítico; e 4. o traço da historicização e o uso do ensaio.

Por fim, em "A opacidade crítica: a linguagem na divisa entre o conceitual e a criação de imagens”, a preocupação foi a de pôr em relevo a sua prática de leitura hermenêutica, o modo como tece a sua linguagem crítica, em que se sobressai inscrito, por vezes, o metafórico.

Palavras-Chave: Benedito Nunes, Literatura, Filosofia, Crítica Literária, Hermenêutica. 
This study is essentially a reflection about the critical work of Benedito Nunes, in what regards its language and its method.

Its language is regarded as a hermeneutical reading where the voices of other literary and philosophical authors as Nietzsche, Heidegger, Ricoeur etc. are heard and whose speeches intermingle with the author`s speech.

In what concerns its method, we tried to accompany the steps of Nunes`hermeneutics in order to stress what he aims at with his texts: the critical interpretations of the questions of Man and World which - as Foucault puts it - results in the author making his own interpretation.

In the first chapter , “ An incursion into the work and the thought of Benedito Nunes” we first tried to consider his main texts in accordance with his critical interpretation and to make an exaustive review of his critical reception.

The second chapter “ Benedito Nunes` critical-reflexive criticism” was divided into what we consider the four main characteristics of his essays:1. criticism as a tension between the writing of the authors and the reading of the critics; 2 . the confrontation between aesthetic and poetic ideas; 3 . the philosophical roots of his theorethical-critical speech; 4. the way historicism and essaysm are being used in his work;

And finally, in our last chapter “ Critical opacity: language between concept and image” we wanted to evidentiate the kind of Benedito Nunes`hermeneutical reading and the construction of his critical language where metaphore sometimes emerges in its relevant role.

key words: Benedito Nunes; Literary Theory; Literary Criticism; Hermeneutics; Literature and Philosophy. 


\section{SUMÁRIO}

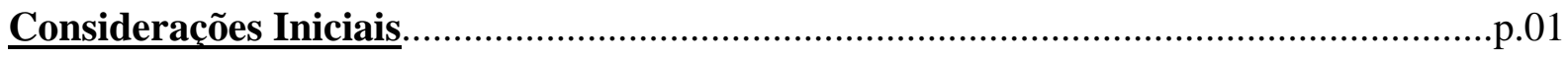

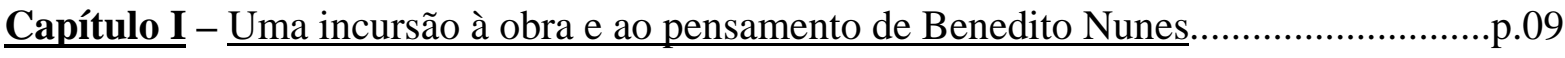

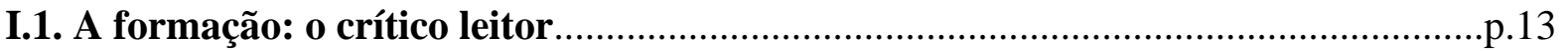

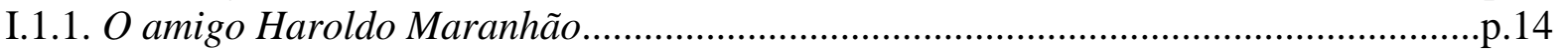

I.1.2. O Suplemento Literário da Folha do Norte..................................................................15

I.1.3. Os poetas do norte: Ruy Barata, João de Jesus Paes Loureiro, Age de Carvalho e

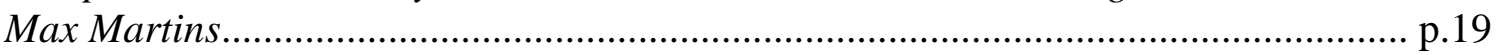

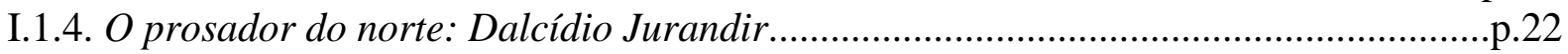

I.1.5. O amigo Mário Faustino.........................................................................................p.23

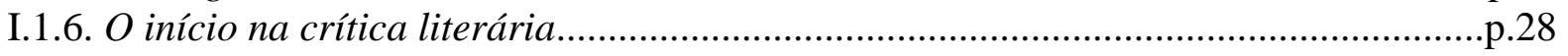

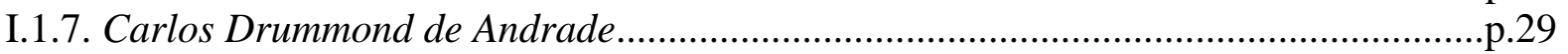

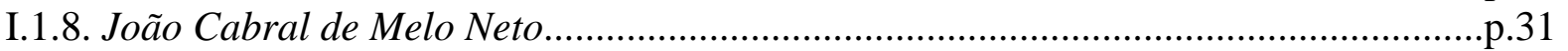

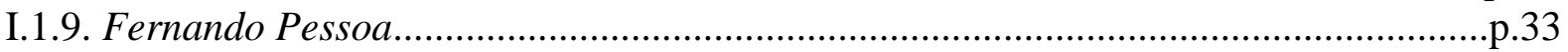

I.1.10. Os poetas Rainer Maria Rilke e T. S. Eliot..................................................................33

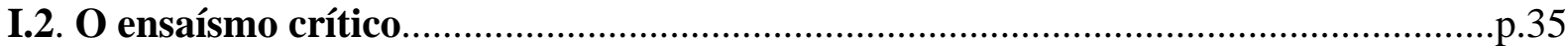

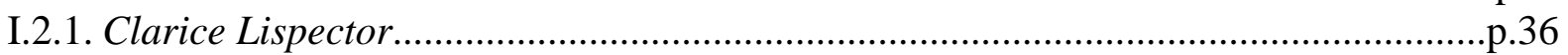

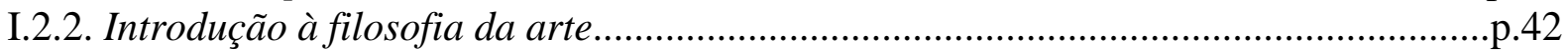

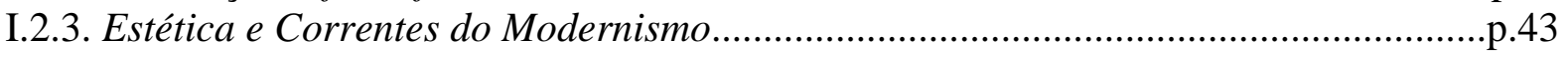

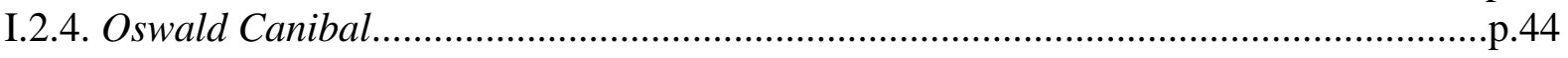

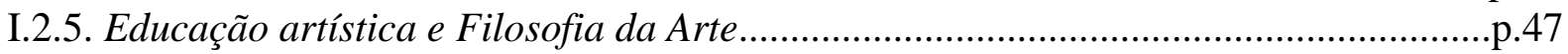

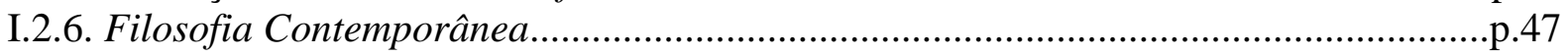

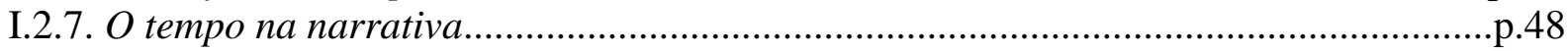

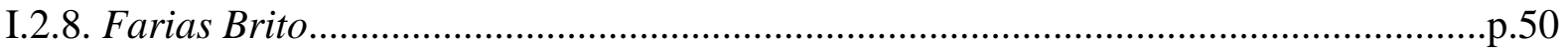

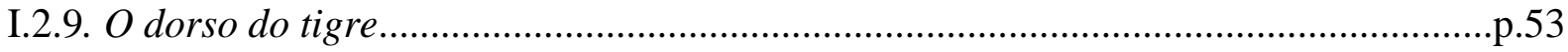

I.2.10. Diretrizes da Filosofia no Renascimento e O universo Filosófico e Ideológico do

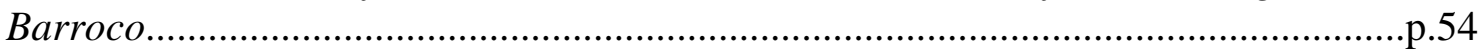

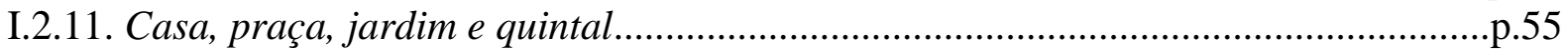

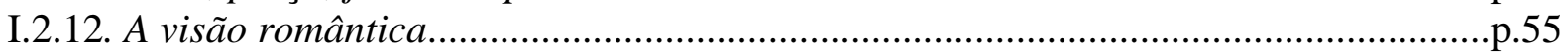

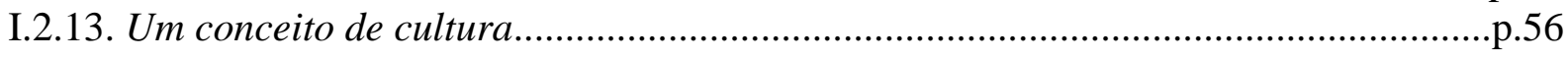

I.3. Outras produções e a recepção à obra de Benedito Nunes................................... p.58

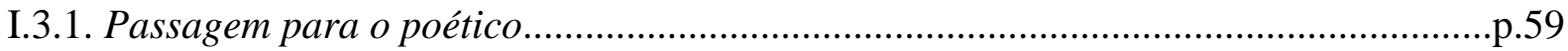

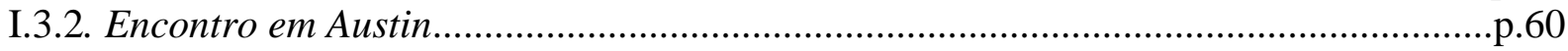

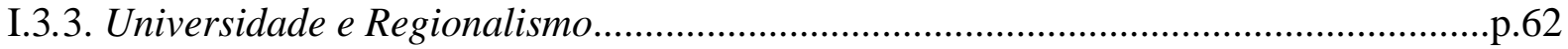

I.3.4. No tempo do niilismo e outros ensaios e Crivo de papel..............................................63

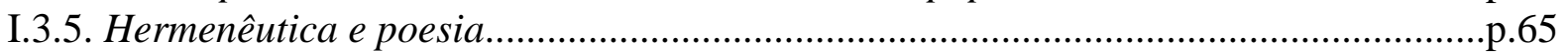

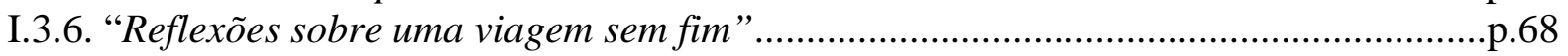

I.3.7. Crônica de duas cidades: Belém e Manaus.....................................................................68

I. 4. Fundamentos do método crítico............................................................................p.70

I.4.1. Breves interfaces do pensamento hermenêutico...........................................................p.73

I.4.2. Hermenêutica e crítica literária: o intérprete Benedito Nunes....................................p.92

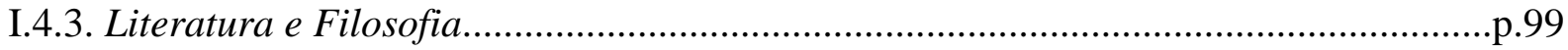

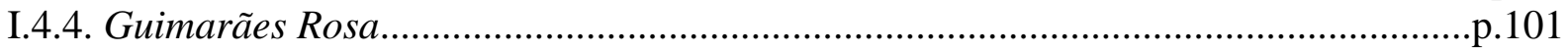


II.1. A questão da leitura e a leitura em questão: tensão entre a escrita dos escritores e a leitura dos críticos.

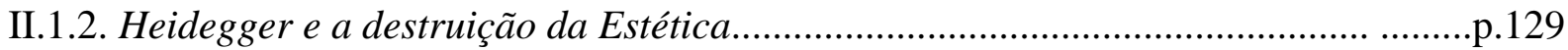

II.1.3. A leitura crítica...............................................................................................p. 130

II.2. O confronto de idéias estéticas e poéticas...........................................................p.135

II.2.1. Diretrizes da historiografia literária e da crítica nacional.....................................p.136

II.2.2. O diálogo crítico de Benedito Nunes.....................................................................p.149

II.3. As raízes filosóficas: marcas do discurso teórico-crítico......................................p.152

II.4. O perfil da linguagem crítica: o traço da historicização e o uso do ensaio............p.160

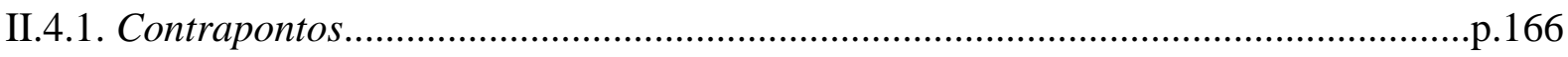

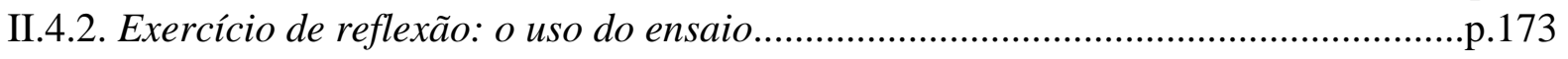

Capítulo III - A opacidade crítica: a linguagem na divisa entre o conceitual e a criação de imagens.

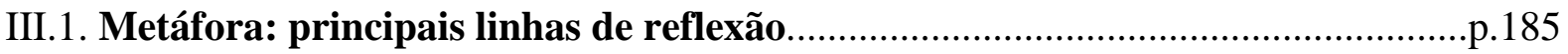

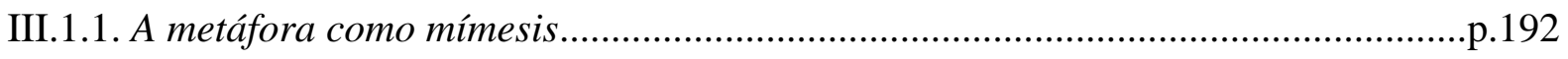

III.1.2. O mundo do texto e o processo interpretativo: a metáfora em cena..........................2.200

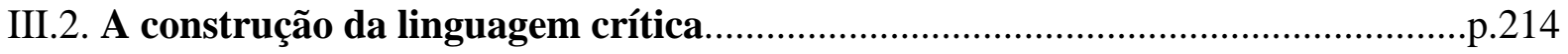

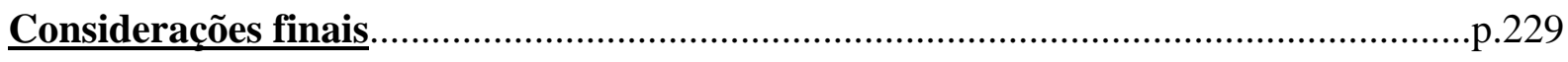

Referências Bibliográficas...................................................................................p.235

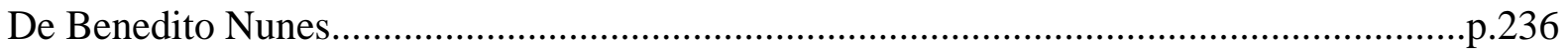

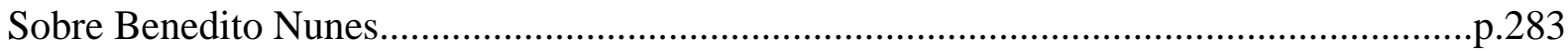

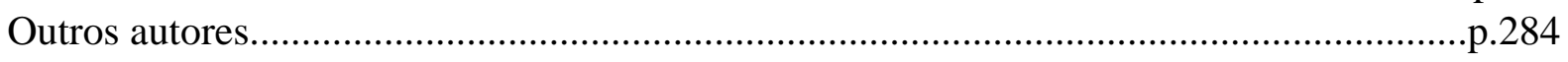




\section{Canção}

a Benedito Nunes

É quando o santo fareja

o mercado com seu nome,

quando

o Quatro, cristo entre somas, lampeja

estiolado em seus antros

e o olho do caos esplende no instante

e o quando-contínuo a narração do tempo

e o quarto perfeito, espaço de quandos

é

tempo de dizer: aqui,

sim,

estou pronto.

(CARVAlHO, Age de. Caveira 41. São Paulo:

Cosac \& Naify; Rio de Janeiro: 7 letras, 2003, p.26) 
Considerações Iniciais 
Benedito Nunes é um nome de referência quando se discute a crítica literária brasileira, em especial, quando se comenta a relação entre a literatura e a filosofia. Inúmeras exposições há acerca desse tema e numerosas são as entrevistas, colóquios, congressos que versam sobre esse ponto da sua obra.

Entretanto, sua vasta bibliografia revela uma abordagem que se abre a outros aspectos, cujas faces de interesses abrangem interrogações da Cultura, da História, da Natureza. São ensaios que contemplam interpretações a respeito da música, do teatro, da religião, do domínio tecnológico, do niilismo dos valores etc.

Tais reflexões são circunscritas a uma leitura hermenêutica, movente na prática prospectiva da pré-compreensão, de caráter circular, inesgotável, que se desdobra em variadas direções. Nessa visada, podem-se encontrar, no seu discurso crítico, vozes que, por vezes, misturam-se à sua identidade escritural, como as de Nietzsche, de Heidegger, de Ricoeur...

O estudo que se segue pretende, antes de tudo, acompanhar os passos da hermenêutica de Benedito Nunes, realçar a problemática que ele imprime ao seu texto; qual seja, o repensar crítico das questões do Homem, do Mundo, em um ato de interpretação que, como lembra Foucault (1967), enreda o próprio intérprete e o faz interpretar-se a si mesmo.

Ainda que a obra de Nunes seja reconhecida no âmbito nacional e internacional, os trabalhos que existem a seu respeito são limitados ao universo da sua crítica literária e de algum livro seu em particular; ou antes, tratam dos autores estudados por ele e, não necessariamente, das especificidades de sua construção analítica.

É o que se verifica, por exemplo, nas seguintes dissertações de mestrado: Alguns aspectos da crítica literária de Benedito Nunes (PUC/RS, 1976), de José Guilherme de Oliveira Castro, a respeito do O dorso do tigre (1969); A filosofia da arte para Benedito Nunes (PUC/RJ, 1978), de Maria Neuza Monteiro, acerca de Introdução à filosofia da arte (1966); Filosofia e ficção: o ser em O drama da linguagem, de Benedito Nunes (UFSC/SC, 2003), de Nilo Carlos Pereira, sobre o princípio do ser na crítica de Nunes, especialmente no livro O drama da linguagem (1989); Perspectivas e possibilidades de aproximação da filosofia e literatura no pensamento de Benedito Nunes (UNICAMP/Campinas, 2003), de Fátima Aparecida Chaguri Oliveira, da área de Educação, voltada à defesa da articulação dos estudos da linguagem literária e filosófica na disciplina de Literatura, com exemplos da crítica de Nunes centrada nos textos de Guimarães Rosa; Diálogos filosóficos com Benedito Nunes 
(UFAM/AM), de Andréa Costa de Andrade, sobre os livros Introdução à filosofia da arte (1966) e Crivo de papel (1998).

Da mesma forma, as resenhas acerca de sua produção, os sites em sua homenagem, ou apresentações de sua obra $^{1}$ não conseguem aclarar ou dar conta da amplitude de seu pensamento.

Da lacuna aberta por essas reflexões é que esta pesquisa nasceu. Na tarefa a que me propus, optei por traçar um panorama de seus textos e discutir pontos-chave da sua escritura. Em outros termos: o que se deseja é pôr em perspectiva a obra de Benedito Nunes, destacar seus temas de interesse, evidenciar seu método de trabalho crítico, sua contribuição à história da crítica literária e demonstrar a relação dialogal e de confrontação que mantém com a literatura e a filosofia.

A escolha de um corpus de trabalho que privilegia tais questões se justifica na medida em que a vasta produção de Benedito Nunes, iniciada na década de 50, expressa, por si só, os diferentes matizes histórico-culturais pelos quais a crítica brasileira atravessou. Isto não significa, contudo, que nomes como Antonio Candido, Luiz Costa Lima, Haroldo de Campos, João Alexandre Barbosa, entre outros, não tenham representado o mesmo papel. Ao longo da pesquisa, a referência a esses pensadores far-se-á necessária para que se estabeleça um debate de idéias e de ângulos de abordagens que, quase sempre diferentes, enriquecem o olhar sobre o literário.

Na verdade, a idéia de um estudo a respeito de Benedito Nunes nasceu da percepção de um diferencial na sua obra; qual seja, a concepção de linguagem que se equilibra na divisa entre o conceitual e a criação de imagens. Além disso, inscrita na tessitura dessa linguagem, há a marca de um diálogo inventivo e profundo entre filosofia e literatura.

Tal articulação, para ele, foi possível desde a Fenomenologia,

graças "à intencionalidade da consciência”, que está para essa posição filosófica de Husserl, como a "vida" está para a Hermenêutica de Dilthey e a "função simbólica" para o pensamento de Cassirer. Seja qual for a espécie que dela derivou (...), pode-se dizer que a "intencionalidade", que levou a Filosofia para o âmbito da existência individual, também a levou para o da experiência literária e artística (NUNES, 1993, p.195).

\footnotetext{
${ }^{1}$ Cf. item I.3. (Outras produções e a recepção à obra de Benedito Nunes), p.58-69.
} 
Na prática de leitura de Benedito Nunes, essas linguagens se intercomunicam e se enobrecem mutuamente: ingressa o poético na filosofia e ingressa o filosófico na poesia, mas sem se igualarem, sem perderem seus traços intrínsecos.

A linguagem, assim, é percebida como constitutiva do próprio pensamento, mas este está preso na "rede de linguagem", como reconhece Nietzsche no Livro do Filósofo (1984) à vontade de "um bando de metáforas, metonímias, de palavras semelhantes e de repetições” (NUNES, 2000a, p.87), contra a qual se rebela.

Nessas condições, é no discurso hermenêutico que a proximidade Filosofia/Literatura opera em grau máximo. Não obstante, para que seja respeitada a extensão de cada disciplina, a relação entre elas se realiza no espaço da crítica, no entendimento das obras.

Para Nunes (2002), refletir filosoficamente é assentar o foco da interpretação em um interesse interdisciplinar, uma vez que a filosofia se compreende como um discurso sobre outros discursos, para os quais também colabora com suas considerações. A abordagem filosófica de uma obra literária, entendida como forma, pode ser investigada, assim, sob três ângulos: a) a linguagem; b) as vinculações da obra com as linhas do pensamento históricofilosófico; e c) "a instância de questionamento que a forma representa, em função de idéias problemáticas, isto é, de idéias que são problemas do e para o pensamento”. (p.205, grifos do autor)

As possíveis questões que surgem neste caminho podem ser formuladas da seguinte maneira: como Nunes realiza a sua leitura hermenêutica? Se a dialogação literatura e filosofia é a marca da sua crítica, quais os princípios e os limites desse intento? Como ele constrói a sua expressão crítica? Neste ponto, pode-se verificar que, como já apontado, a sua linguagem se apresenta no limite entre o conceitual e a criação de imagens. Assim, se há, por vezes, o metafórico inscrito na sua escritura, qual será a sua concepção de metáfora? De que forma a crítica literária de Benedito Nunes parte da metáfora para iniciar um processo interpretativo?

A hipótese, portanto, é que a atividade da crítica, para Nunes, tem como objetivo ressaltar os momentos de repetição, os paradoxos, as inovações sintáticas e sonoras, o ritmo, as inúmeras figuras de linguagem que povoam as obras analisadas para investigá-las em face dos questionamentos histórico-filosóficos e abordá-las de forma a deixar vir à tona reflexões que são confrontações do e para o pensamento. Uma forma de ler que privilegia o instrumental da criação para colocá-lo em relevo. 
A crítica de Nunes, ao compartilhar da criação verbal do poeta/prosador, alia a sensibilidade teórica e a analítica como a de quem concorda, como Ricoeur (1990, p.104), que o mais importante é desvelar a referência do texto, o mundo o qual ela descortina e redescreve. Compreender um texto, portanto, é postar-se perante o mundo da obra, para entendê-lo e, por extensão, entender a si mesmo, já que "toda interpretação envolve (...) uma preliminar e antecipada autocompreensão do intérprete”. (NUNES, 1999, p.57)

A referência própria do texto, ou de segundo grau, conforme o filósofo francês, é onde repousa o campo da metáfora, a estratégia de discurso responsável por permitir à interpretação uma dinâmica de leitura que não procura algo que está por detrás do texto, mas apropria-se das questões abertas pela potência criadora da linguagem poética.

Ao proceder a uma leitura hermenêutica, é o conceito de metáfora, discutido por Ricoeur, que Nunes corrobora nas suas abordagens; tema este que, oportunamente, no capítulo três, será mais bem estudado.

Ao longo da leitura de (com) Benedito Nunes, algumas questões da sua construção crítica serão postas em destaque. Para tanto, dividirei o trabalho em três momentos.

O primeiro, intitulado “Uma incursão à obra e ao pensamento de Benedito Nunes”, apresentarei um mapa da sua produção, explicitarei seus principais temas - por ex. a relação entre a literatura e a filosofia, a concepção de Cultura, de Natureza, de História - bem como realizarei uma leitura dos pensadores e dos escritores por ele examinados na sua ensaística.

É necessário esclarecer que não haverá uma preocupação em traçar um perfil biográfico, embora isto se acenturá, de uma maneira ou de outra, seja por meio das inúmeras entrevistas que existem a seu respeito - e que serão reproduzidas na tese -, seja por fatos e situações que ele próprio, nos seus ensaios, revela. Assim, tentarei sublinhar algumas passagens da vida de Benedito José Viana da Costa Nunes (1929-), como o morar em Belém, o início da crítica no Suplemento Literário Folha do Norte (1946 a 1951), a convivência com os “amigos do Norte”, como o Prof. Francisco Paulo Mendes, Haroldo Maranhão, Mário Faustino, Max Martins, entre outros.

No item "Fundamentos do método crítico" procurarei mostrar alguns conceitos da tradição hermenêutica - a romântica de Schleiermacher e Dilthey; a ontológica de Heidegger e a filosófica de Gadamer; a crítica de Habermas e a fenomenologia hermenêutica de Ricoeur -, para pôr em pauta a contribuição desse método à crítica literária e, mais especificamente, para ressaltar a afinidade de Benedito Nunes com o duplo trabalho da hermenêutica 
pretendida por Ricoeur (1990, p.43): o desdobrar da dinâmica interna do texto e o restaurar do poder de a obra se projetar para fora na representação de um mundo habitado por nós.

No segundo capítulo, denominado “A crítica crítico-reflexiva de Benedito Nunes”, farei um jogo espelhado da hermenêutica: ao tangenciar o discurso de Nunes, ele próprio um empreendimento hermenêutico, comentarei e acrescentarei reflexões diante da possibilidade de outras faces de abordagem.

Selecionarei quatro aspectos do seu corpus ensaístico: a crítica definida como tensão entre a escrita dos escritores e a leitura dos críticos; o confronto de idéias estéticas e poéticas; o discurso teórico-crítico marcado por uma postura filosófica e o procedimento da historicização e o uso constante do ensaio.

As discussões de tais traços obedecerão à linha empregada por Nunes na confecção de seus escritos: em breves excursos, pontuarei histórica e filosoficamente as principais questões e, em seguida, estas serão articuladas com o pensamento do crítico paraense.

Já no último momento, “A opacidade crítica: a linguagem na divisa entre o conceitual e a criação de imagens”, o estudo, no essencial, concentrar-se-á no seu modus operandi, no “como” de sua leitura hermenêutica, de sua construção textual.

Ao revelar a maneira como edifica suas abordagens críticas, a imagem aparecerá junto a problemas que são impasses do e para o pensamento. Estudarei, então, o metafórico inscrito, em muitos momentos, na sua linguagem, com variados exemplos de suas críticas literárias.

Quanto à base teórica do trabalho, trarei à baila a discussão sobre os rumos da crítica em autores/teóricos como o próprio Benedito Nunes, Leyla Perrone-Moisés, João Alexandre Barbosa, Luiz Costa Lima, entre outros. Debaterei sobre o escopo da filosofia, prioritariamente, de Nietzsche, de Heidegger e de Ricoeur, que, de certa forma, são aqueles com quem Nunes tem maiores afinidades.

As referências bibliográficas de e sobre Benedito Nunes, que constam ao fim da tese, foi a mais completa que eu pude preparar, mesmo em meio a tantas falhas, como a ausência de paginação. Aliás, a pesquisa em seu acervo, que ele gentilmente me abriu, revelou que ainda há um trabalho longo para ser realizado, pois faltam muitas referências em recortes de jornais, sem contar que não houve, por parte do próprio autor, uma preocupação em organizar suas publicações. Se há algum mérito nesta tese, é que foi dado um primeiro passo para tal evento. 
Há de se ter claro que este estudo não é simplesmente sobre Benedito Nunes; é sobre certo Benedito Nunes, aquele recortado pela minha leitura, com o qual estabeleci uma interlocução que, tal como seus escritos, está longe de se esgotar.

Reflexões que marcam a tônica de uma pesquisa que pretende, acima de tudo, fazer da experiência da leitura, “particular e momentânea”, um aprendizado da experiência da vida, “geral e cumulativa”, como diria Benedito Nunes (1998, p.175). 
“Cedo entrei (...) no círculo bibliográfico infinito, o único verdadeiro moto perpétuo que conheço. Pela leitura de um só livro, pode-se chegar a todos os outros, com tempo e disposição”.

(Benedito Nunes) 
CAPÍTULO I

Uma incursão à obra e ao pensamento de Benedito Nunes

O próprio Benedito Nunes (1929-) reconhece que foi Clarice Lispector quem mais soube entender o conjunto de sua obra crítica. No texto "Meu caminho na crítica” (2005), ele 
lembra que, após a publicação de O drama da linguagem (1989), a escritora foi emblemática: "Você não é um crítico, mas algo diferente, que não sei o que é”1 (p.289)

Talvez Clarice percebesse que a atividade textual de Nunes também procura "tocar a linguagem”. Talvez o “algo diferente” seja que, para ele, o discurso é sempre múltiplo, carregado de vozes nem sempre harmônicas. Se há muito de uma pulsão “poética” em cada fio de sua escrita, também há o rigor reflexivo que exige do leitor, tal qual um Ulisses cauteloso, uma atenção redobrada, a ponto de não se perder na tessitura de suas palavras, no seu tom meditativo, por vezes pedagógico.

Benedito Nunes é sempre lembrado como o crítico que trouxe à Literatura uma visão filosófica. Ou antes, um pensador que tem se dedicado aos estudos literários. Todavia, sua experiência de leitura de mundo é mais abrangente, pois envolve uma interrogação da Cultura, da Natureza, da História, como questões que suscitam sempre um novo olhar. O passeio por temas tão diversos mostra um constante exercício interpretativo que entende a crítica, tal como Kant já a definiu², indissociável da Filosofia. Neste sentido, a obra literária é, para a Filosofia-crítica, objeto que revela ou desvela suas indagações. A Filosofia e a Literatura aparecem como linguagens intercambiantes, como domínios que se entrelaçam, mas que não se reduzem. O poético desponta na Filosofia, assim como esta se manifesta na poesia. Há a intercomunicação, mas cada qual conserva sua identidade, sua característica.

É dessa rede de associações, desse diálogo, que a qualidade de sua produção se sobressai. São ensaios construídos por uma linguagem acurada, por uma interpretação ${ }^{3}$ cujo método nasce do próprio texto-objeto, legitimado por um gesto hermenêutico que se equilibra entre o conceitual e a criação de imagens espelhadas pela própria obra estudada.

Sua atividade crítica, assim, não se esgota na análise, mas na leitura atenta das relações que a arte, em especial a literatura, estabelece entre a linguagem, o mundo e sua historicidade, nas possibilidades de um pensamento aberto a novos horizontes sobre o procedimento crítico.

Neste sentido, em três momentos particularmente - “Ocaso da literatura ou falência da crítica?” (1999a), “Crítica literária no Brasil, ontem e hoje” (2000) e “Meu caminho na

\footnotetext{
${ }^{1}$ Provavelmente, o livro a que se refere Benedito Nunes deve ser Leitura de Clarice Lispector (1973) e não $O$ drama da linguagem (1989), que é uma edição revista pelo autor daquela obra. O mesmo comentário pode ser conferido no livro Conversas com filósofos brasileiros (2000, p.81-2).

${ }^{2}$ Cf. NUNES, Benedito. "Meu caminho na crítica" (2005), p.289, e "Crítica literária no Brasil, ontem e hoje" (2000), p. 51-2.

${ }^{3}$ A teoria da interpretação fundamentada pela hermenêutica será discutida mais adiante.
} 
crítica” (2005) -, Benedito Nunes reflete sobre a relação crítica-literatura de forma bastante significativa.

São textos que, dado o teor histórico-literário, possibilitam revisitar as diversas tendências da pesquisa nacional e delinear o perfil de um crítico sempre atento às vicissitudes e incertezas que o ato analítico ${ }^{4}$ promove.

No primeiro, trata-se de um artigo, datado de 13 de julho de 1998, que expõe, brevemente, um quadro progressivo e epistemológico do conceito de crítica e uma descrição problematizadora da atual prática literária, responsável por uma recepção interpretativa limitada, muitas vezes, só ao ambiente universitário.

A idéia central, portanto, é mostrar a dupla articulação entre literatura e crítica: esta como exercício de leitura daquela que, por sua vez, só pode existir se for lida. Embora o próprio Nunes reconheça tratar-se de uma afirmação simples, é a maneira como constrói seu cerne argumentativo o aspecto que merece ser comentado, já que transforma esta questãochave em uma imagem que, por si só, traduz um crítico-leitor:

\begin{abstract}
Mas poderá ocorrer, como certos sinais pressagiam, que a literatura venha a perder, algum dia, sua ressonância crítica, se não vier ela própria, também, a definhar, tornando-se, à falta de leitura, um simulacro de si mesma. Um simulacro igual àquele que da bela Helena de Tróia ficara, incólume e fiel a Menelau, resguardada no Egito, segundo nos conta Eurípedes, enquanto a verdadeira teria ido, com Paris, incendiar Îlion, provocando a guerra da Ilíada. (1999a, p.11)
\end{abstract}

Esta passagem será retomada e desenvolvida no parágrafo final do seu texto:

O que, então, fazer com a literatura, não com o simulacro, a belíssima, imediatista e utilitarista Helena, que teria ficado no Egito, mas com a sedutora, a mitopoética Helena, aquela que conflagrou Tróia, que não vive sem crítica e morre sem leitura? (1999a, p.21)

O aparente caráter circular da exposição tem, antes, a função de pôr em relevo aquilo mesmo que já foi evidenciado como proposição nuclear; qual seja, a crítica só persiste como retorno à interpretação de grandes obras literárias, cuja configuração inventiva, marcada por experimentalismos poéticos, demanda estudos e considerações reflexivas.

Para tanto, o procedimento analítico adotado na explanação é um comentário de grau histórico-literário caracterizador do papel da crítica, em geral, e do crítico, em particular, desde a Antigüidade até o século XX. Tais indicações, embora abrangentes, são

\footnotetext{
${ }^{4}$ Dificilmente, nos estudos literários, a crítica é dissociada da análise. Cf. TELES, Gilberto Mendonça. Introdução à crítica histórica. In: Função da crítica (1980), p.26-7.
} 
acompanhadas de observações significativas, em que, mesmo no uso da primeira pessoa do plural, respondem por uma concepção de análise:

Quando avaliamos as obras, nós as vemos sempre de certa perspectiva, que nos
limita e nos ensina as viseiras de nossos juízos de valor. Isso é um excelente ganho
da Hermenêutica e das Estéticas da recepção, como o é, também, o reconhecimento
do caráter mutável dos cânones, que já sabia o semioticista Mukarovski, quando os
vinculou a condições geracionais de idade, de profissão, de classe social e de nação.
(1999a, p.20)

A referência à Hermenêutica, constante deste trecho, merece uma nota à parte que farei posteriormente ${ }^{5}$. Por ora, é preciso enfatizar, ainda com relação a este artigo, que Nunes destaca o desempenho da imprensa, desde a década de 40 até meados de 1970, como "uma das principais caixas de ressonância pública da literatura em nosso país”. (1999a, p.17) Lembra, inclusive, que as primeiras análises de obras como as de João Guimarães Rosa, as de João Cabral de Melo Neto e as de Clarice Lispector nasceram jornalisticamente.

Nomes, como os de Alceu de Amoroso Lima (Tristão de Athayde), de Álvaro Lins, de Wilson Martins, de Afrânio Coutinho, de Sérgio Buarque de Holanda, de Lúcia Miguel Pereira, de Augusto Meyer, de Otto Maria Carpeaux, de Antonio Candido, de Adolfo Casaes Monteiro, de Jorge de Sena, de Franklin de Oliveira e de Euryalo Canabrava, são mencionados como os expoentes que escreviam, assídua ou regularmente, no espaço de jornais como Diário de Notícias, Correio da Manhã, Jornal do Brasil e Estado de S. Paulo ${ }^{6}$.

O ponto curioso é que Nunes não se inseriu nesse ciclo de jornalismo literário, nem tampouco quando fez a mesma referência a este período, inclusive com alusões aos autores já citados, no texto “Crítica literária no Brasil, ontem e hoje” (2000). Sinal, talvez, de modéstia, ou, por outra, de quem quer se poupar de criticar a si próprio. O fato é que suas análises, primeiro no "Suplemento Dominical” do Jornal do Brasil (a partir de 1956) e depois no “Suplemento Literário” do Estado de S. Paulo (a partir de 1959), são exemplos mais do que vivos de como esses veículos contribuíram para recepcionar a literatura.

Aliás, em “Crítica literária no Brasil, ontem e hoje” (2000), Nunes amplia as idéias já expostas em “Ocaso da literatura ou falência da crítica?” (1999a) e constrói um estudo tanto panorâmico quanto intenso sobre as principais linhas teórico-metodológicas da investigação, bem como evidencia suas plurais concepções e seu estatuto de gênero em crise ${ }^{7}$. Novamente,

\footnotetext{
${ }^{5}$ Cf. o item I.4. (Fundamentos do método crítico), p.70.

${ }^{6}$ No capítulo 2, retomarei esse assunto.

7 É interessante apontar que Cláudio Willer, no artigo “Crise da crítica” (Revista Cult, ano V, nํㅜ 49, agosto de 2001), vale-se deste texto para reelaborar esse debate.
} 
há referência a escritores e obras seminais, num arco que se estende desde as principais vertentes no Brasil, com Sílvio Romero e José Veríssimo, até às contemporâneas pesquisas acadêmicas.

Embora igualmente não se autodenomine pertencente a esta ou aquela corrente, é perceptível sua compreensão sobre a crítica como um momento de "tensão entre a escrita dos escritores e a leitura dos críticos" e seu quadro histórico como "o roteiro de uma experiência pessoal da literatura, privilegiando a poesia.” (2000, p.54)

Parece-me oportuno, desta forma, ao margear este roteiro de leitura, comentar sua trajetória crítica, nascida do contato com a imprensa, e matizar algumas considerações sobre o percurso traçado. Percurso este que ele próprio rememora, de forma sumária, em "Meu caminho na crítica” (2005) ${ }^{8}$, texto-guia, permeado de reentrâncias, aberto, como um convite, para acompanhar seu pensamento.

\section{I.1. A formação: o crítico leitor}

O trato com a palavra impressa, em Benedito Nunes, vem desde a adolescência quando, aos 14 anos, em 1943, junto com Haroldo Maranhão, então com 16, publicaram um jornalzinho chamado “O Colegial”, que circulava entre as escolas de Belém.

Haroldo Maranhão (1927-2004), neto do jornalista Paulo Maranhão, proprietário da Folha do Norte, em circulação desde o século XIX, era secretário do vespertino desse jornal. A afinidade literária com Nunes resultou, também naquela época (1943), em uma sociedade chamada "Academia dos Novos", inspirada na Academia Brasileira de Letras, de cunho passadista, em defesa do clássico Parnaso, cuja sede era a casa onde Benedito Nunes morava com a mãe e as tias.

A Belém daquela época pouco conhecia do Modernismo; vivia do precário transporte que a ligava às Metrópoles do Sul e, da passagem pela cidade, em 1927, de Mário de Andrade, assimilou mais os estudos de folclore do poeta paulistano do que os versos “futuristas” de Paulicéia desvairada. Para o então adolescente Benedito Nunes,

isso tudo justifica mas não explica nosso retardamento literário de jovens versejadores acadêmicos. Pois que fundamos nossa própria Academia com poltronas austríacas, lustres, patronos ilustres, posse solene e discurso de recepção. Só

\footnotetext{
${ }^{8}$ Originalmente, este texto foi um depoimento dado por Benedito Nunes durante o III Ciclo de Conferências “Caminhos do crítico”, na Academia Brasileira de Letras, em 17 de maio de 2005.
} 
começaríamos a modernizar-nos depois da morte de Mário de Andrade, em 1945. Max Martins, honra lhe seja feita, antecipou-se a esse processo de geral conversão estética. Bancando o Graça Aranha, gritou Morra a Academia! Numa sessão solene. E saindo espaventosamente da sala, ou do recinto, conforme dizíamos, foi sentar-se no banco público fronteiro à minha casa, sede do silogeu, onde esperou a saída dos confrades para a costumeira badalação em bando pelas ruas da cidade ${ }^{9}$.

A “descoberta” do Modernismo aconteceu em 1946, mesmo ano em que é criado, sob a direção de Haroldo Maranhão, o "Suplemento Literário” como parte integrante da Folha do Norte, inicialmente com o título de "Suplemento Arte-Literatura” e, mais tarde, "Suplemento Artes-Letras”, que vigorou até 1952.

Escreveram, em suas páginas, autores de diferentes regiões, como Carlos Drummond de Andrade, Cecília Meireles, Manuel Bandeira, Murilo Mendes, Ledo Ivo, Marques Rebelo e outros, que se mesclaram aos escritores locais - entre eles, Max Martins, Ruy Barata, Paulo Plínio Abreu, Cauby Cruz, Mário Faustino.

\section{I.1.1. O amigo Haroldo Maranhão}

Haroldo Maranhão e Benedito Nunes travaram uma amizade que perdurou ao longo de sessenta e um anos. Autor de contos, de novelas e de romances, Maranhão foi laureado inúmeras vezes por seus mais de vinte textos publicados, entre eles, o Prêmio Guimarães Rosa 1980, por O Tetraneto Del-Rei (Francisco Alves, 1982); o Prêmio da União Brasileira de Escritores/SP 1981, por A morte de Haroldo Maranhão (GPM Editora, 1981); o Prêmio José Lins do Rego 1982, por Anões (Ed. Marco Zero, 1983); e o Prêmio Vértice da Literatura 1983, Coimbra, Portugal, por A porta mágica (Scipione, 1999).

Se Nunes consagra $O$ dorso do tigre (1969) a ele, em O Tetraneto Del-Rei é a vez de Maranhão homenageá-lo: “(...) Na minha vida, não tive mais que dois amigos. Um é Benedito Nunes, amigo perfeito, para quem estas páginas são também dedicadas” ${ }^{\text {10 }}$. Na contracapa desse livro, encontramos um pequeno comentário de Nunes, cujas observações enaltecem Maranhão pelo uso de uma linguagem inventiva na confluência das duas literaturas, a portuguesa e a brasileira, já que o romance mimetiza o modo de escrever seiscentista.

\footnotetext{
9 NUNES, Benedito. “Max Martins, mestre-aprendiz”. Texto datado de dezembro de 1991, editado como prefácio à obra Não para consolar (Ed. Cejup,1992), de Max Martins, e republicado na revista Asas da palavra - Revista do Curso de Letras do Centro de Ciências Humanas e Educação da UNAMA - Universidade da Amazônia, v.5, n 11, julho de 2000.

${ }^{10}$ MARANHÃO, Haroldo. O Tetraneto Del-Rei. Rio de Janeiro: Francisco Alves, 1982, p.211. (Nota do Autor).
} 
A verve paródica é o estilo que reponta em outras duas obras de Maranhão: Cabelos no Coração (Coleção Verso e Reverso, nº. 2, Rio Fundo Editora, 1990), sobre a vida de Felipe Patroni ${ }^{11}$, e Memorial do fim - a morte de Machado de Assis (Ed. Marco Zero, 1991) ${ }^{12}$, em cuja apresentação Nunes esclarece sobre essa narrativa lúdica: “Machado de Assis morituro, personagem de romance, permanece na órbita de sua própria ficção. Quem morre, superpondo Carolina a Carmo, a bela Fidélia à prestimosa Hilda, é o Conselheiro Ayres, cujo Memorial chega ao último fim”13. Também coube a Benedito Nunes a apresentação do último livro de Haroldo Maranhão, O nariz curvo (2001), coletânea de oito contos editada pela Secretaria Executiva da Cultura em parceria com a imprensa Oficial do Estado do Pará.

Na homenagem que Benedito Nunes escreveu quando da morte de seu amigo, ressaltou que este, por sua criação verbal, foi considerado um “Dom Quixote da linguagem”. Diga-se de passagem, “Dom Quixote” era o nome da famosa Livraria que Haroldo Maranhão abriu um pouco antes de ir ao Rio de Janeiro. Foi, sem dúvida, um lugar marcado por importantes encontros de intelectuais, como o da tarde de autógrafos com o casal Jean-Paul Sartre e Simone de Beauvoir, em 1960, quando da estada deles na capital paraense, antes de seguirem viagem a Cuba.

Embora Belém fosse personagem constante em suas obras, Maranhão foi um autor que “conseguiu ultrapassar a tradicional mediania regionalista do Extremo-Norte do país”14.

\section{I.1.2. O Suplemento Literário da Folha do Norte}

É no “Suplemento Literário” da Folha do Norte que vem a público, de 1946 a 1952, “Confissões do Solitário” - mais de sessenta aforismos, numerados em arábico -, que Benedito Nunes, após a leitura de Nietzsche em espanhol, escreveu. Tais fragmentos, como ele nos explica, põem à prova,

de encontro a um vago neopaganismo neles preconizado, matrizes de minha formação católica, [em que] misturavam conceitos filosóficos e imagens poéticas, sob o foco de uma reflexão céptica, certamente agnóstica, sobre problemas religiosos, morais e estéticos, alimentada pela vária, incessante, quase obsessiva leitura de Homero e Shakespeare, Santayana e Unamuno, Pascal e Walt Whitmann,

\footnotetext{
${ }^{11}$ Participante destacado da luta pela independência na Revolta da Cabanagem (1823-1840); fundador do jornal "O Paraense”, um dos principais instrumentos da causa.

${ }^{12}$ Sobre este livro Cf. TEIXEIRA, Lucilinda Ribeiro. Ecos da memória - Machado de Assis em Haroldo Maranhão. São Paulo: Annablume, 1998.

${ }^{13}$ NUNES, Benedito. Apresentação. In: MARANHÃO, Haroldo. Memorial do fim - a morte de Machado de Assis. São Paulo: Marco Zero, 1991.

${ }^{14}$ NUNES, Benedito. Eu e Haroldo. Encarte, Belém, julho de 2004.
} 
Baudelaire e Goethe, Renan e Gide, Dostoievski e Kant, Anatole France, Eça de Queiroz e Monteiro Lobato (o do Urupês e o do Picapau Amarelo). (2005, p.292)

A tônica do seu "hibridismo crítico" origina-se dessas leituras, oscilantes entre filósofos e literatos, entre reflexão e criação, já que, para ele, a Filosofia e a Literatura são instâncias que se movem de maneira conjunta, mas não-redutíveis. A respeito disto afirmou em “Meu caminho na crítica” (2005):

Não pretendi e nem pretendo aplicar a filosofia, enquanto método uniforme, ao
conhecimento da literatura, nem fazer da literatura um instrumento de ilustração da
filosofia ou uma figuração de verdades filosóficas. Se fosse o caso, teria que recorrer
a determinada filosofia - pois que temos filosofia no plural e não no singular -
passando então a literatura, sob exame crítico, à condição de serva de um método
filosófico. O que nos levaria ao seguinte contra-senso: a filosofia já está implícita na
crítica literária. Sejam quais forem, os métodos da crítica literária sempre têm uma
maneira à priori, por assim dizer filosófica, de conceber e de avaliar o alcance do
texto literário, em função de um fenômeno mais extensivo que o engloba, seja a
linguagem, seja a sociedade, seja a história. (2005, p.292)

Convém lembrar que o estudo da Filosofia foi fruto de um autodidatismo metódico, como o era, em grande parte, a busca pelo conhecimento de muitos outros autores paraenses, desde a época de José Veríssimo, “o melhor e mais competente autodidata dentre os expoentes paraenses das “idéias novas””. (NUNES, 1999b, p.7)

Em breve, mas agudo texto - "Dois mestres e uma só lembrança” (2003) -, Nunes recordou dois de seus professores de História, no ginásio do Colégio Moderno - Arthur Cezar Ferreira Reis e Maria Annunciada Chaves -, também formados pelas leituras que lhes davam o notório saber, não por cursos especializados:

Ele [Arthur Cezar Ferreira Reis] era um afincado leitor, como Maria Annunciada Chaves; ambos possuíam cuidadosas bibliotecas. Tinha eu quinze ou dezesseis anos quando me passou, por empréstimo, Casa Grande \& Senzala: um dos livros brasileiros mais envolventes e mais híbrido, misto de antropologia, história e sociologia, escrito num estilo próprio, inimitável. Como não admirar esses dois professores tão parodoxais, como parodoxais eram os melhores mestres da época: ensinavam da melhor forma, da maneira mais inteligente, hábil, não superficial e compreensível, em bom, claro e límpido português, sem terem tido outra formação específica senão a da leitura sistemática e quotidiana dos livros de suas bibliotecas! Bacharéis em Direito, autoformaram-se professores. Então, o autodidatismo era próspero e feliz, como foi o de Eidorfe Moreira”. (p.7)

Desde os 19 anos, Nunes lecionou Filosofia no curso ginasial, além de História Geral e do Brasil. No entanto, formou-se bacharel em Direto pela Faculdade de Direito do Pará, em 1952: 
Eu tinha um tio que morava em São Paulo, Carlos Alberto Nunes, que era tradutor. Ele estava disposto a me receber em sua casa para eu estudar filosofia na USP. Meu estudo seria custeado por um outro tio, irmão dele, que naquela época era banqueiro. Mas esse meu tio banqueiro faliu. E o que eu ia fazer? Entrar para medicina? Para farmácia? Odontologia? Acabei entrando em direito, onde se ensinava bem teoria do conhecimento. Trabalhávamos muito o livro de Hartmann: Metafísica do conhecimento. Grande parte desse livro era dada no curso de direito. Essa parte foi muito boa, mas o resto eu abominava, principalmente a parte de legislação e de direito positivo. (NUNES, 2000, p.69)

De 1954 a 1960, ministrou aulas de História da Filosofia e Ética, nos cursos de Pedagogia, Ciências Sociais, História e Biblioteconomia na Faculdade de Filosofia, Ciências e Letras da Universidade Federal do Pará ${ }^{15}$, onde se tornou Professor Titular em $1966^{16}$, responsável pelas disciplinas de Introdução à Filosofia, História da Filosofia, Ética e História do Pensamento Filosófico e Científico.

É também notória a sua inclinação ao teatro. Na década de 60, junto com a esposa, Maria Sylvia Nunes ${ }^{17}$, fundou a Escola de Teatro e Dança da Universidade Federal do Pará, onde ministrava aulas de Estética.

A primeira viagem do casal à França, em 1960, deveu-se a essa arte:

Nossa dedicação ao teatro - a Maria Sylvia, sobretudo, dirigia - rendeu uma viagem à França. Ela montou a tragédia "Édipo Rei”, de Sófocles. Fomos com a peça participar de um festival universitário em Santos. Ela ganhou o festival e o prêmio da viagem: em navio, de primeira classe. Eu - que era apenas o "marido da professora” - tive que conseguir dinheiro junto ao Capes para poder viajar. Passamos seis meses na França. Fizemos vários cursos. Ela tinha direito a estágios e a freqüentar vários teatros, inclusive nos ensaios. Íamos a museus... Estudei com o professor Paul Ricoeur, na Sorbonne ${ }^{18}$.

\footnotetext{
${ }^{15}$ Benedito Nunes foi um dos fundadores da Faculdade de Filosofia do Pará, posteriormente encampada pela Universidade Federal do Pará.

${ }^{16}$ Mesmo com a aposentadoria, em 1992, ainda orienta teses e, por vezes, leciona Teoria da Crítica.

${ }^{17}$ Maria Sylvia Nunes criou o Grupo Norte Teatro Escola, em 1957, com o qual organizou um extenso repertório que abrangeu peças de Tchekov, de Sófocles, de Ionesco, de Ibsen, de Sartre, entre outros. Sob sua direção, foi encenada, pela primeira vez no Brasil, Morte e Vida Severina, de João Cabral de Melo Neto, no Teatro do Derby e no Teatro Santa Isabel, em Recife, quando do Primeiro Festival Nacional de Teatros de Estudantes (1958), com música de Waldemar Henrique. Esta montagem possibilitou que João Cabral recebesse o Prêmio de Melhor Autor Teatral daquele ano. Em 1990, fez um ensaio de leitura dramática da mesma peça para os estudantes da classe de Português, de responsabilidade do Professor Rodolfo Franconi, do "Departament Spanish and Portuguese", da Universidade de Vanderbilt, em Nashville, Tenessee. Premiada no Brasil e no exterior, Maria Sylvia Nunes foi professora titular da disciplina "História do Espetáculo", no curso de Formação de Ator da Escola de Teatro do extinto Serviço do Teatro da UFPA.

${ }^{18}$ Entrevista concedida ao jornal O Liberal, Cad. O Cartaz, Belém, 19 de abril de 1998, p.4. No mesmo ano, estuda com Merleau-Ponty no Collège de France.
} 
Por ocasião dos 70 anos de Nunes, José Carlos Castro deixa registrado, em um artigo publicado no jornal $O$ Liberal $^{19}$, as principais atividades acadêmicas do professor paraense ao longo do tempo:

Dirigiu, na UFPA, Seminário de Atualização, ministrou cursos de Aperfeiçoamento
e Atualização para Professores e Alunos, nos mais diversos e importantes temas de
seu domínio cultural. Sob a sua coordenação, fruto de sua amizade, Michel Foucault
ministrou o primeiro curso no Brasil, intitulado "História da Sexualidade”, matéria
do livro que seria editado (1976). Do mesmo modo, ministrou cursos de Pós-
Graduação e Aperfeiçoamento na Universidade de Campinas, São Paulo,
Universidade de Brasília, Universidade Federal do Rio de Janeiro, Universidade
Federal da Paraíba e Universidade Federal do Ceará. No exterior, lecionou e dirigiu
seminários na Université de Haute-Bretagne - Rennes II, na França; na University of
Texas at Austin (EUA); Vanderbilt University, em Nashville (EUA); Universidade
de Stanford (EUA); Universidade de Montreal (Canadá), também em Portugal e
Uruguai.

O "Suplemento" da Folha do Norte significou assim, pode-se dizer, um impulso à sua formação intelectual, uma possibilidade de delinear seu tema investigativo assinalado pela busca de uma articulação entre a imagem e o conceito, como o primeiro longo ensaio que escreve - A morte de Ivan Ilitch-, resultado de leituras de Goethe, Kierkegaard, Rilke, Kafka, Sartre, Paul-Louis Landsberg. ${ }^{20}$ Da mesma forma, as reuniões, quase que diárias, à noite, no Café Central (uma área do Central Hotel), cercado de intelectuais, jornalistas, literatos, contribuíram para a sua identidade cultural.

Nesses encontros, com a presença de Haroldo Maranhão, Mário Faustino, Machado Coelho, Ruy Barata, Paulo Plínio Abreu, Raymundo Moura, Cléo Bernardo, Sílvio Braga e Rui Coutinho, o professor de literatura Francisco Paulo Mendes (1910-1999) era a grande referência como mestre ${ }^{21}$. Foi por meio de suas aulas que Nunes ouviu falar, pela primeira vez, de Clarice Lispector ${ }^{22}$. Também, sob sua influência, na soma de duas gerações diferentes, criou-se um “espírito comum” na forma de perceber, sentir e pensar o real e a literatura:

\footnotetext{
${ }^{19}$ O Liberal, Cad. O Cartaz, Belém, 19 de dezembro de 1999, p. 12-13.

${ }^{20}$ Cf. entrevista feita pelo jornal O Liberal de 19/04/1998 com Benedito Nunes e o livro Conversas com filósofos brasileiros (2000, p.74).

${ }^{21}$ O livro O amigo Chico fazedor de poetas (2001), que Benedito Nunes organizou e do qual fez a introdução, apresenta depoimentos e recordações de pessoas que, como ele, tiveram sua história vinculada à de Francisco Paulo Mendes.

${ }^{22}$ Cf. “Dona Clarice” In: Dois ensaios e duas lembranças (2000), p.43-7. Aliás, em Um sopro de vida (Rio de Janeiro: Nova Fronteira, 1978), Clarice Lispector cita Francisco Paulo Mendes, a quem ela conhece e com quem trava amizade quando da sua estada em Belém, em 1944, para onde o marido, Maury Gurgel Valente, fora enviado como vice-cônsul: “(...) Hoje, entrando em casa, dei um profundíssimo suspiro como se tivesse chegado de longa e difícil jornada. Pessoas desaparecidas. Onde estão? Quando alguém souber delas telefone para a Rádio Tupi. Cadê o desaparecido Francisco Paulo Mendes? Morreu? Me abandonou, achou que eu era muito importante...”(p.145)
} 
Esse espírito comum era o cultivo dos mesmos autores, poetas e filósofos, muito dos quais Mendes apontou para nós. Ele dizia: "Leia Julien Green, leia François Mauriac, ou então leia Rainer Maria Rilke”, pelo qual ele era apaixonado. Então surgiu esse espírito comum que, como todo espírito comum, era um pouco faccioso, pois nós cultivávamos esses autores e detestávamos outros. (...) Naquela época, havia ainda relações que se formavam em torno de mesas de café. O golpe de misericórdia foi dado em 1964, porque todos estavam sob suspeita de ser comunistas. Claro que nós éramos mais de esquerda do que de direita - óbvio! Tínhamos as nossas simpatias, tínhamos amigos comunistas, mas não pertencíamos a nenhum partido, o que fazia parte desse espírito comum. Encontrei uma frase em um livro de Unamuno, que eu usava muito naquela época, corroborando as posições de Mendes, que dizia: "homem de partido, homem partido". E, assim, esse grupo durou muito. Mendes, depois, continuou a debater idéias e expor seus pontos de vista na casa de um amigo mais velho, que não freqüentava o Café Central, Machado Coelho. Essa fase foi muito importante, porque daí começamos a conhecer certos autores, e eu comecei a conhecer certos filósofos como Heidegger, Sartre, Paul Landsberg. (NUNES, 2000a, p.74)

A participação de Benedito Nunes na vida cultural e artística de Belém foi, e ainda é, de extrema importância e, sua obra, ponto de referência da cultura paraense. Nos chamados “anos de chumbo", compartilha da luta por um ideal contrário à política que vigorava. Por este motivo, foi indiciado em um inquérito pelo Coronel Décio Fleury Charmillot, o que contribuiu para que ele viajasse, em 1970, para New York, custeado por uma bolsa de estudos da Guggenheim Foundation.

\section{I.1.3. Os poetas do norte: Ruy Barata, João de Jesus Paes Loureiro, Age de Carvalho e Max Martins}

Por essa época, dois poetas conhecidos de Benedito Nunes também tiveram problemas com a censura política: Ruy Guilherme Barata (1920-1990) e João de Jesus Paes Loureiro (1939-).

O primeiro foi advogado, professor, político (deputado estadual pelo Partido Social Progressista em dois mandatos). Dirigiu o Suplemento Literário de A Província do Pará, no qual Mário Faustino publicou crônicas no estilo de Rubem Braga. Foi professor de Literatura Brasileira da Faculdade de Filosofia, Letras e Artes (mais tarde incorporada à Universidade Federal do Pará). Em 1964, com o golpe militar, foi preso e aposentado compulsoriamente do magistério superior, mas retornou a ministrar aulas após a anistia, em 1979. Parceiro de seu filho, Paulo André Barata, suas canções tornaram-se emblemáticas do repertório paraense. 
Da sua vasta produção, Nunes, no texto "Meus poemas favoritos de ontem \& hoje” (2005), destacou “O nativo de Câncer”, de Antilogia, publicado postumamente em 2000 pela Secult/RGB; e “Ode”, de Linha imaginária, 1951.

No mesmo artigo, Nunes ressaltou um poema, sem título, de $O$ ser aberto (Cejup,1991), de João de Jesus Paes Loureiro. Em razão da sua poesia participativa, da sua forte militância política, Loureiro igualmente foi preso e torturado pela ditadura militar. No final da década de setenta, tornou-se professor da Universidade Federal do Pará e, a partir de 1983, exerceu funções de Secretário Municipal de Educação e Cultura de Belém; Superintendente da Fundação Cultural “Tancredo Neves”; Secretário de Cultura; de Educação; e Presidente do Instituto de Artes do Pará.

Suas Obras reunidas (Escrituras Editora, 1999), composta de quatro volumes, contêm, no primeiro, prefácio de Nunes intitulado “O Nativismo de Paes Loureiro”.

Neste texto, em um primeiro momento, o trabalho de Paes Loureiro foi comentado na linha de intersecção com a poesia e a crítica de Mário Faustino por um projeto poético de debate estético-político. A idéia, que Mário Faustino disseminou na sua coluna no Jornal do Brasil, era a de um poeta com compromisso político, mas com autonomia de sua arte, sem amarrá-la ao domínio das exortações.

Esta questão traduzia em manifestações a necessidade de "novas formas e processos" para o “desenvolvimento e avanço da poesia brasileira”. É assim que, em 1963, Benedito Nunes assinou o Manifesto de Poesia de Vanguarda, junto a nomes como Haroldo e Augusto de Campos, Décio Pignatari, Affonso Ávila, Lais Corrêa de Araújo, Luiz Costa Lima, Pedro Xisto, Roberto Pontual e Affonso Romano de Sant’Anna.

Na segunda fase de Paes Loureiro, Nunes assinalou a dominância de palavrasimagens, fruto da leitura da obra de Mário Faustino, principalmente a "parte posterior de $O$ Homem e sua Hora”. Já a terceira, foi "balizada por uma visão amazônica do mundo, internacionalmente construída, ao encontro do legado da primeira geração modernista paraense”.

Neste sentido, comparou sua matéria verbal, fincada na busca existencial por uma visão amazônica do mundo, ao termo de Mário de Andrade - radicação ("arte de implantar a raiz da arte e da poesia na entidade coletiva nacional") - expresso no "Movimento Modernista” (1942). 
Por fim, notou o nativismo da poesia do escritor, verificável no uso regional da língua portuguesa e no aspecto sexual da natureza. No entanto, concluiu Nunes, a abundante utilização de entidades míticas, “a tipificação das imagens e a ênfase discursiva dos torneios sintáticos expõem a eloqüência ao permanente risco da redundância, em que muitas vezes recai”.

Nos anos oitenta, as reuniões, aos sábados, na casa de Benedito e Maria Sylvia Nunes, em que se encontravam poetas, romancistas, contistas, pintores, músicos, artistas de teatro, professores da universidade, constituíam-se em trocas de experiências, reflexões e divulgação de novos autores.

Foi em uma dessas sessões que Age de Carvalho (1958-), apresentado a Nunes por Francisco Paulo Mendes, conheceu Max Martins (1926-) e, juntos, escreveram a renga A fala entre parênteses (1982), com dedicatória ao casal Nunes. Isto porque, a idéia do livro surgiu de uma sugestão do professor paraense - que escreveu o prefácio intitulado “Jogo marcado” e de Maria Sylvia, com base em um exemplar da renga de Octavio Paz, Edoardo Sanguineti, Charles Tomlinson e Jacques Roubaud, que eles trouxeram como novidade de uma viagem dos EUA.

Age de Carvalho, arquiteto pela Universidade Federal do Pará, trabalha, atualmente, como designer gráfico em Viena, onde reside. Sua primeira obra - Arquitetura dos Ossos (Ed. Falângola/Semec, 1980) - foi indicada ao prêmio-publicação em um concurso da Secretaria de Cultura de Belém, do qual Benedito Nunes participava como jurado. Na coleção Claro Enigma, da Editora Duas Cidades, dirigida por Augusto Massi, editou Pedra-um (1990) e, junto com este, escreveu Móbiles (Ed. 7 Letras, 1998). Caveira 41 (Cosac \& Naif, 2003) e Seleta - Antologia poética (Ed. Paka-Tatu, 2004) são suas últimas obras publicadas no Brasil.

Max da Rocha Martins, autodidata, realizou estudos particulares nas áreas de Literatura, Poesia, Artes e Filosofia. Entre 1946 e 1951 publicou poemas que viriam a fazer parte de O Estranho no Suplemento Literário da Folha do Norte. O estranho (1952), seu primeiro livro de poesia, conquistou o prêmio Frederico Rhonsard, concedido pela Academia Paraense de Letras, e o Santa Helena Magno, pela Secretaria de Educação do Estado do Pará. Trabalhou como noticiarista e secretário de redação do jornal Folha do Norte, de 1962 a 1964. Na década de 80, participou de Leitura de Poemas, com os poetas James Bogan, Age de Carvalho, Vicente Cecim e da Oficina Literária Afrânio Coutinho, com o poeta de Caveira 41 (2003). Fez palestras e leitura de poemas nas universidades de Columbia, St. Louis e Rolla (EUA), em 1987. Exerceu o cargo de diretor da fundação cultural Casa da Linguagem, entre 
1990 e 1994, e recebeu, em 1993, o prêmio de poesia Olavo Bilac, concedido pela Academia Brasileira de Letras, pelo livro Não para Consolar (1992), volume que reúne suas obras e tem prefácio de Benedito Nunes.

Em comemoração aos 80 anos do poeta, Nunes escreveu o texto "Belém de Max Martins” (2006 - inédito) para a palestra na X PAN Amazônica (Feira de livros), realizada em Belém, no dia 17 de setembro de 2006.

\section{I.1.4. O prosador do norte: Dalcídio Jurandir}

A capital paraense é também evocada pela memória do romancista Dalcídio Jurandir (1909-1979) cujos livros - Chove nos campos de Cachoeira (1941), Marajó (1947), Três casas e um rio (1958), Belém do Grão-Pará (1960), Passagem dos Inocentes (1963), Primeira manhã (1967), Ponte do Galo (1971), Chão dos Lobos (1976), Os habitantes (1976) e Ribanceira (1978) - relatam situações, personagens e linguagens pertencentes ao universo de Cachoeira (cidade onde passou sua infância) e ao de Belém (onde viveu até mudar-se para o Rio de Janeiro).

Linha do Parque (1951) é a única narrativa que não pertence ao ciclo do ExtremoNorte, como ele denominou as escrituras acima. Estava o autor ligado ao Partido Comunista, que exigia um compromisso com o realismo socialista, com o qual Dalcídio Jurandir não afinava. "E para não traí-lo [ao Partido], ou trair-se, fez-se outro autor (...) escreveu um livro de aventuras, com personagens heroificados lutando em prol da causa do Partido. O autor é aí uma personalidade literária diferente. Um heterônimo”. (NUNES, 2004a, p.18)

Em 1972, Jurandir recebe o Prêmio Machado de Assis, da Academia Brasileira de Letras, pelo conjunto da sua obra.

Para Benedito Nunes, os romances de Dalcídio Jurandir formam um imenso ciclo amazônico que guarda, no entanto, considerável distância
das experiências regionalistas. São ficções que apresentam uma interiorização muito
grande, cada vez mais densa; são, na verdade, as aventuras de uma experiência
interior. Chego a pensar que o conjunto desses romances formam uma espécie de $\grave{A}$
La Recherche...escrita na Amazônia e que Dalcídio é, um pouco, o nosso Proust ${ }^{23}$.

\footnotetext{
${ }^{23}$ Entrevista a José Castello, O Estado de S. Paulo, Caderno 2, 1983, www.secrel.com.br/poesia/castel06html. (Acesso em $1^{\circ}$ de março de 2003.)
} 
Em um dos textos que escreveu sobre este autor - "Dalcídio Jurandir: as oscilações de um ciclo romanesco" (2004a) $)^{24}$ - ratificou a idéia do seu “ciclo romanesco" ter um parentesco proustiano, pois se caracterizam por apresentar histórias que se subdividem em outras, de forma circular e em longo período temporal, a depender da memória, lembrança de quem narra.

Na reminiscência de Alfredo - alter ego do autor -, presente como figura de ligação dos romances, a poetização da paisagem do Extremo-Norte, bem como a introspecção analítica da personagem afasta o ciclo de Dalcídio Jurandir das "práticas narrativas do romance dos anos 30, como certa constrição do meio ambiente e a tendência objetivista documental, afinada com a herança naturalista”. (NUNES, 2004a, p.17)

Benedito Nunes comentou brevemente, nesta reflexão, cada um dos livros dalcidianos, em especial Belém do Grão-Pará $(1960)^{25}$, exemplo de romance-crônica da Belém dos anos 20 e 30. Pelos olhos do menino Alfredo, a descrição da cidade é recriada poeticamente: o Vero-Peso ganha densidade pictórica, assim como “as ruas sombreadas de mangueiras, o Largo da Pólvora sonolento, com o Teatro da Paz, neoclássico, no meio da verdura, as casas baixas ajaneladas, de corredor ou puxadinha, os sobrados revestidos de azulejos que brilham ao sol”. (idem)

Ao final, retomou o pensamento, anteriormente citado, de como cada romance de Dalcídio Jurandir apresenta a memória dos que o antecedeu, memória-lembrança proustiana, “que é sempre recordação da infância, se não for sonho de juventude”. (NUNES, 2004a, p.21)

\section{I.1.5. O amigo Mário Faustino}

Acima citei Mário Faustino (1930-1962). É preciso que se diga que a primeira aproximação entre eles ocorreu em 1947, no dia três de novembro, na primeira e única sessão da ABDE, Associação Brasileira de Escritores, fundada por Haroldo Maranhão (seu primeiro e único presidente) e por Ruy Barata.

Mário Faustino, naquele momento, publicava crônicas no "Suplemento" editado semanalmente pelo jornal A Província do Pará, dirigido por Frederico Barata. Mais tarde,

\footnotetext{
${ }^{24}$ Este texto é originalmente a palestra proferida quando da inauguração do Instituto Dalcídio Jurandir, na Fundação Casa de Rui Barbosa - Rio de Janeiro/RJ, em julho de 2003. Foi reeditado recentemente em Dalcídio Jurandir - romancista da Amazônia. Organização de Benedito Nunes, Ruy Pereira e Soraia R. Pereira. Belém: SECULT; Rio de Janeiro: Fundação Casa de Rui Barbosa/Instituto Dalcídio Jurandir, 2006, p.245-51.

${ }^{25}$ A mais recente edição é de 2004, resultado de uma parceria da Editora da Universidade Federal do Pará e da Casa de Rui Barbosa. Benedito Nunes escreve e assina a contracapa do livro.
} 
tornou-se chefe de redação da Folha do Norte. O vínculo entre eles, que se seguiu durante longos anos, foi registrado por Nunes em diversos momentos, como em um pequeno texto intitulado “Meu amigo Mário”, do livro Dois ensaios e duas lembranças (2000b):

\begin{abstract}
Não saberia dizer como se firmou entre nós o pacto da amizade. Na Belém de trezentos mil habitantes, pós-Segunda Guerra Mundial, havia, apesar do calor, clima para longas caminhadas a pé, para passeios nos velhos bondes, que seriam os últimos ou nos novos ônibus, que então começaram a circular, e para demoradas conversas nas casas de um e de outro, que se prolongavam nos cafés, sobre os livros que líamos. De caminhada a caminhada, de leitura a leitura, tornamo-nos íntimos, fraternais amigos: visitávamos-nos mutuamente sem hora marcada. (p.39)
\end{abstract}

Em Mário Faustino: uma biografia, de Lilia Silvestre Chaves (Belém: Secult; IAP; APL, 2004), a amizade que une os dois escritores está presente de modo intenso, narrada basicamente como duas biografias que se entrelaçam, seja por meio da descrição das correspondências que eles trocavam, seja no relato constante que Nunes faz à autora, e que lhe serve de guia para tecer sua obra, seja pelo momento específico "Meu amigo Mário" (o mesmo título do texto de Nunes), que Chaves retoma para contar a vida de Mário Faustino até 1956, quando este, então, parte para o Rio de Janeiro.

O livro tem o prefácio escrito por Benedito Nunes que, a princípio, questiona o fato de este ser sobre a biografia de Faustino e não sobre um estudo crítico do autor. No entanto, reconhece que é "impossível escrever a vida de um poeta, sem que o conhecimento de sua obra não passe a primeiro plano. Principalmente quando se trata de um poeta como Mário Faustino, para quem poesia e vida deveriam correr paralelas”.

Segundo Nunes (2000a, p.76), foi Mário Faustino quem lhe mostrou a necessidade de escrever com clareza: "Quando eu mandava os artigos para o Jornal do Brasil, ele dizia: 'Ótimo, ninguém escreve coisas tão importantes. Mas é muito tortuoso, é preciso tornar as idéias claras"”.

Trabalharam juntos, no início da década de 50, na Superintendência do Plano de Valorização Econômica da Amazônia (SPVEA): Nunes como Chefe de Setor e Faustino, Redator, em um cargo hierarquicamente subordinado a ele.

Ainda com Haroldo Maranhão, tentaram fundar, em 1948, a revista literária Encontro, que só teve um número, apesar de impressos cerca de 500 exemplares. Conta-nos Nunes que, em Belém, ele e Mário Faustino fizeram a impressão da Revista e mandaram para Haroldo Maranhão, que se encontrava no Rio de Janeiro; este, porém, não gostou e vetou a sua distribuição. 
A primeira crítica de Nunes com relação ao trabalho de Faustino ${ }^{26}$ aconteceu em um artigo no "Suplemento Arte-Literatura" da Folha do Norte de 31 de dezembro de 1950. Sob o pseudônimo João Afonso, comentou a antologia “Dez poetas paraenses”, que havia sido publicada no domingo anterior. Em tal análise, teceu observações pouco elogiosas ao seu amigo e a ele próprio com relação aos poemas que produzia naquele momento: “os achados puramente casuais não representam uma conquista definitiva na vida do poeta. É o que nos sugere a poesia do Sr. Benedito Nunes (...) mostrando-se quase inteiramente desprovido do manejo da técnica do verso”. (Folha do Norte, 31 de dez., 1950, p.1 e 3)

Depois, publicou na mesma Folha, em 14 de janeiro, “Considerações sobre A Peste”, em que assina Benedito Nunes e coloca, entre parênteses, o pseudônimo, para revelar quem era João Afonso. Aliás, no ano seguinte, em fevereiro de 1952, o mesmo artigo foi transcrito na revista Norte (1951-1952), dirigida por ele, Max Martins e Orlando Costa, cuja edição resumiu-se a três números de periodicidade bimestral. Além do texto sobre o livro de Albert Camus, Nunes escreveu “As idéias do Existencialismo”, denso ensaio sobre o pensamento de Sartre; para ele, autor em que a relação entre Filosofia e Literatura apresenta-se de forma extrema ${ }^{27}$.

Após a morte de Mário Faustino, em 1962, foi publicada, no ano seguinte, na Revista Invenção - Arte de Vanguarda, um artigo de Benedito Nunes intitulado "O projeto de Mário Faustino”, junto a uma série de homenagens de poetas e amigos do autor de Vida toda Linguagem.

Em 1966, Nunes organizou e fez o prefácio de Poesia de Mário Faustino (Ed. Civilização Brasileira), volume póstumo de Faustino, que reunia poemas inéditos e outros disseminados em jornais de Belém e do Rio de Janeiro. Faustino editou apenas um único livro - O Homem e sua Hora - , em 1955, mas deixou uma extensa obra composta de contos, crônicas, impressões de viagem, artigos, ensaios jornalísticos e críticos.

A poesia de Mário Faustino recebeu, em um primeiro momento, influência de Baudelaire, Rimbaud, Rilke, Lorca, Cecília Meireles, Fernando Pessoa, Saint-John Perse, até ser tocada pelos poetas de língua inglesa contemporânea: T. S. Eliot, e.e. cummings, Hart Crane, Dylan Thomas e Ezra Pound, de quem se tornou discípulo e divulgador de suas reflexões sobre crítica.

\footnotetext{
${ }^{26}$ Cf. Mário Faustino: uma biografia, de Lilia Silvestre Chaves (Belém: Secult; IAP; APL, 2004), p.165 a 173.

${ }^{27}$ Cf. "Meu caminho na crítica” (2005, p.300).
} 
O Homem e sua Hora, ao lado de Luta Corporal (1954), de Ferreira Gullar, e Duas Águas (1956), de João Cabral de Melo Neto, pode ser incorporada, segundo Nunes (1986, p.19), no distinto elenco da alta produção poética da década de 50:

As composições líricas em ritmos e disposição estróficas diferentes - de preferência o decassílabo, a canção e o soneto - deste livro de 1955, a que o poema-título de 236 versos, O Homem e sua Hora, serve de fecho, tematizam os grandes contrastes espirituais, éticos e religiosos da existência, projetando-os ora num plano mítico, ora num plano cultural histórico, através de imagens opostas e recorrentes - solares e noturnas, marítimas, telúricas, ctonicas e atmosféricas - de fecundidade e esterilidade, de mudança e permanência, perecimento e ressurreição, vida e morte, temporalidade e eternidade - interligadas por uma cadeia de alusões, tanto bíblicas (sacrifício de Isaac, Crucificação, traição de Judas, David e Saul, São Sebastião) quanto clássico-humanísticas (heróis, poetas, deuses, semideuses e obras da literatura greco-latina, principalmente a Eneida e os poemas Homéricos). (NUNES, 1986a, p.22 - grifo do autor)

Mais que poeta-crítico, Mário Faustino era crítico-poeta. Isto porque,

segundo a tradição literária ocidental, a expressão "poeta-crítico", inversa e complementar à de “crítico-poeta”, aponta para três estilos de prática do poema: a de arte poética, a de fabricação da poesia, no sentido de criação verbal, trabalhosa, agônica, e a de renovação ou criação de novas formas poemáticas. Mário Faustino adotou-os nas três fases - e tão curtas formas que mais apropriado seria chamá-las de momentos - em que podemos dividir o desenvolvimento de sua poesia: $\mathrm{O}$ momento de $O$ homem e sua Hora, o intermediário, dos poemas ditos 'experimentais', e o final, dos ‘fragmentos’. (NUNES, 2002b, p.49)

Sua página, denominada "Poesia-Experiência”, do “Suplemento Dominical” do Jornal do Brasil (1956-1958), representou um momento singular na ensaística brasileira, em que a teoria e a prática poéticas eram discutidas e refletidas sob o lema "Repetir para aprender, criar para renovar”. Em 1977, pela Editora Perspectiva, Benedito Nunes organizou e escreveu a introdução de Poesia-Experiência, com ensaios e artigos do referido espaço. Também pela Fundação Casa de Jorge Amado, com apresentação de Nunes, Evolução da poesia brasileira (1993) concentra os principais textos da série “Poesia-Experiência”.

Nos anos de 1985 e 2000, mais duas coletâneas de poemas de Faustino saem com a organização de Nunes, respectivamente: Mário Faustino: poesia completa e poesia traduzida (São Paulo: Max Limonad) e Melhores poemas de Mário Faustino (São Paulo: Global).

Importante lembrar da conferência pronunciada por Benedito Nunes - A obra Poética e a Crítica de Mário Faustino -, em 28 de maio de 1985, no Conselho Estadual de Cultura do Pará, sobre os 30 anos do surgimento de O Homem e sua Hora, impresso depois, em 1986, com um adendo rememorativo sobre o poeta. 
Desde 2002, Maria Eugenia Boaventura, professora da UNICAMP, pesquisa e organiza, pela Companhia das Letras, a obra de Faustino com a colaboração de Nunes, que guarda o acervo do poeta.

Os livros de Mário Faustino encontram-se dispostos no mezanino da Torre, biblioteca de Nunes mais antiga e que lhe serve também de escritório, construída na parte externa da casa. As pastas que pertenceram ao escritor ficam na Bicom I (Biblioteca Complementar). Aliás, os incontáveis volumes pertencentes a Nunes situam-se nas diversas “Bicons” - são cinco -; na verdade, extensões da Biblioteca Central, localizada dentro da casa, no lado esquerdo, onde o professor Benedito Nunes organiza também sua coleção de CDs e de vídeos.

Perguntado sobre quantos livros possuía, respondeu:

Não posso precisar-lhe quantos livros tenho. O último catálogo que tentei organizar data de meus vinte anos. Convencido de que era uma prática sorvedoura de tempo, deixei, desde então, de contabilizar minha biblioteca. Trato dela sozinho, seu forte é Filosofia e Literatura quase em partes iguais. Só uma concessão à burocracia: procuro manter, a duras penas, um registro de empréstimos; saídas não são raras para estudantes e colegas. Algumas, infelizmente, tornam-se atestados de óbito: inúmeras as reposições que tenho feito. Pelo que disse até aqui, já se adivinhou quanto tempo levei para juntar esses livros, que somados aos de Maria Sylvia e Angelita, ocupam mais de quatro compartimentos da casa. Tem a biblioteca mais do que a minha idade, porque surgiu antes de mim. Sou seu funcionário único, e até agora pude controlá-la impecavelmente. É certo que lhe impus uma ordem pessoal; sei onde encontrar cada livro de acordo com o assunto (História da Filosofia, Filosofia da Ciência, Religião, Psicologia, Crítica Literária, Romances Brasileiros, Romances Estrangeiros, Poesia e assim por diante). Não trago a biblioteca na memória. Ela é, de certo modo, a minha memória, feita de perdas, lembranças e recuperações. Gostaria de recuperar alguns dos meus antigos hóspedes, como certas obras da Coleção Terramarear (Mowgli, o menino lobo, Jacala, o crocodilo, de Kipling; Tarzan, o Rei das Selvas, de Edgar Rice Burroughs; Pinocchio, de Colodi) ou a Poesia de Manuel Bandeira editada pela Casa do Estudante do Brasil. Não sofro da obsessão de querer renovar o alumbramento da primeira leitura, embora persista a nostalgia da experiência passada. Cada qual tem o paraíso perdido que merece. $\mathrm{O}$ meu é livresco. Se fosse rico compraria a Bibliothèque de la Plêiade inteira, todos os volumes da Coleção Budé e dos clássicos Loeb; também colecionaria edições de Shakespeare assim como os novos-ricos colecionam santos barrocos. Mas longe estou do tradicional bibliófilo, com gosto de edições raras, à busca de obras finamente encadernadas ou de luxo. No entanto, o livro, instrumento de trabalho para riscar e anotar, adquire a meus olhos identidade física, com sua capa, o cheiro do papel, o formato, a posição da estante. Nesse ponto pareço-me com D. Pedro II, para quem cada livro era um estimulante dos sentidos da vista, do tato e do olfato. Assim é que os guardo na memória, catálogo único, compulsado onde quer que esteja. Os mais valiosos são os que melhor me servem, me ajudam, me acompanham: Fragmente der Vorsokratiker, de Hermann Diels; Kant completo, 13 vols., na Edição de 1921 da Academia de Berlim; Fichte, também completo, em 6 vols., Edição de 1922; Schopenhauer, idem, em 6 vols. Reclam; História da Filosofia, de Uberweg, 4 volumes, Berlin, 1906; Suma teológica, 16 vols. Latim/Francês, 1853 (presente de Chico Mendes); La Philosophie de la Nature de JDel.de Sales, Paris, 1804, 10 vols. (obtido numa troca com Machado Coelho); os 
livros de poesia (Pound, Dylan Thomas, Cummings etc.), que pertenceram a Mário Faustino $^{28}$.

O primeiro volume de Mário Faustino preparado pela Companhia das Letras traz a reedição de $O$ Homem e sua Hora, com um texto de Benedito Nunes intitulado “A poesia de meu amigo Mário” e um comentário na contracapa. De Anchieta aos concretos (2003) e Artesanatos de poesia (2004) completam, até o momento, a coleção.

\section{I.1.6. O início na crítica literária}

Necessário se faz assinalar que Nunes iniciou-se não como crítico, mas como poeta ${ }^{29}$. Tentou escrever um romance, segundo ele, espelhado em Menino de engenho, de José Lins do Rego, mas este não avançou do segundo capítulo ${ }^{30}$. Foi o mestre Francisco Paulo Mendes quem o encaminhou para o ensaio. “A Estréia de um Poeta”, publicado em 1952, no jornal Folha do Norte, sobre o livro de Max Martins, O estranho, marcou seu início na crítica literária, depois, conforme declarou, “de haver abandonado, por lúcida e acertada decisão, a arte poética”. (NUNES, 2000c, p.21) ${ }^{31}$

Em tal artigo, ao aproximar Max Martins do Drummond anterior a Alguma poesia, Brejo das almas e José fez observações contrárias à linguagem modernista, fragmentada, ao ritmo não-formal dos versos. Desta forma, ao sublinhar problemas na poesia do autor paraense acabava por acoimar também o poeta mineiro. No prefácio ${ }^{32}$ ao livro Não para consolar (Ed. Cejup, 1992), de Max Martins, Nunes retificou sua leitura e assumiu criticar a própria crítica. Esta nova postura analítica ocorreu, no entanto, devido a dois fatores que cooperaram para o desenvolvimento da poesia de Max Martins: a publicação de O Homem e sua hora (1955), de Mário Faustino, e o encontro intelectual com Robert Stock, o "Homem da Matinha”.

Em diversos momentos (como nesse prefácio ao livro de Max Martins), bem como em entrevistas, Benedito Nunes contou sobre a convivência com esse americano, que apareceu

\footnotetext{
${ }^{28}$ Entrevista concedida ao jornalista Lúcio Flávio Pinto para o jornal A Província do Pará, de 26 de maio de 1991. Também há um impresso desta denominado "Um roteiro dos livros de um sábio paraense", editado pela Universidade Federal do Pará também em 1991.

${ }^{29}$ Há poemas seus publicados, por exemplo, na antologia “Dez poetas paraenses”. In: Folha do Norte, Pará, 24 de dezembro de 1950.

${ }^{30}$ Cf. "Meu caminho na crítica” (2005, p.289).

${ }^{31}$ Cf. nota da p.14.

${ }^{32}$ Ibid.
} 
em Belém por volta de 1951 e se instalou, com a mulher e a filha, no bairro da Matinha, em um barraco de chão batido, coberto de palha. Sua subsistência era custeada pelas aulas particulares de inglês, mas seu tempo era dedicado quase que exclusivamente à poesia.

Teve alguns poemas traduzidos por Mário Faustino e publicados no número três da Revista Norte. Conforme relatou Nunes,

\begin{abstract}
da parte de Bob a lição poética sempre trazia uma contraparte ética: a moral empenhada à poesia como valor principal norteando o exercício da arte feito prática de vida, solitária e ascética, acima do ideal burguês de vitória sobre o mundo, o poeta como oposto de self-made-man, auto-suficiente e dominador; ao contrário daquele que 'vence na vida', está inteiramente entregue ao 'craft or sullen art' (ofício ou arte severa) do verso de Dylan Thomas. A vitória do poeta seria fracasso aos olhos do mundo para o romântico Homem ou Santo Homem da Matinha, que eu voltaria a encontrar em 1970, já em New York, free-lancer em publicidade e ainda pobre, depois de haver publicado seu primeiro livro, (Covenants, Trident Press, New York, 1967), com poemas dedicados a Ruy Barata, a outros amigos de Belém e à memória de Mário Faustino, morto em 1962. (NUNES, 2000c, p. 22-3)
\end{abstract}

Quanto a Drummond, o crítico paraense recusara, na verdade, a piada modernista, que, porém, reconheceu depois, já havia no Drummond anterior A rosa do povo e redimiu-se por não ter percebido a "permeabilidade da linguagem moderna ao cômico, ao burlesco, ao bufo, ao ‘drolático’ (o vocabulário de Guimarães Rosa)”. (NUNES, 2000c, p.24)

\title{
I.1.7. Carlos Drummond de Andrade
}

A comprovada eficácia da linguagem drummondiana foi ressaltada depois em diversos momentos; por exemplo, no ensaio “Carlos Drummond: a morte absoluta”, publicado na Revista da Biblioteca Mário de Andrade (jan./dez.2002/2003) e em um texto intitulado “Drummond, poeta anglo-francês”. (NUNES, 2002d) ${ }^{33}$

No primeiro, Nunes comentou que a morte, para o poeta mineiro, é um índice de inconformismo e de resistência ética, cujo desagrado acontece porque, além de mortais, somos e vivemos "morituros", em um ciclo eterno que gira e liga os vivos e os mortos: “antecipadamente derrotados, porém humanamente inconformados, a sentença que de nada informa ao ser executada”. (p.29 - grifo do autor)

Com relação ao artigo, “Drummond, poeta anglo-francês” (2002d), o crítico paraense lembrou que Mário Faustino, na década de 50, ao transpor o poema "Estância” de Drummond

\footnotetext{
33 Originalmente, este texto é um artigo publicado no jornal O Estado de S. Paulo, São Paulo, 02 de setembro de 1973, Suplemento Literário, p.01.
} 
para o inglês, mostrou que a poesia deste, por suas potencialidades universais em ritmo, significações e imagens, poderia perdurar em qualquer outra língua. É também nesta época que Robert Stock verteu, para a língua inglesa, uma série de poemas de Drummond, publicados mais tarde em diversas revistas norte-americanas.

Benedito Nunes comentou igualmente a versão para o francês da obra do poeta mineiro feita por Jean-Michel Massa, mesmo autor que, em tese de Doctorat d'état, defendida na Faculté de Lettres et Sciences Humaines de Poitiers em 1969, escreveu sobre a biografia de Machado de Assis ${ }^{34}$. Em considerações referentes ao trabalho de Massa, Nunes refletiu sobre a questão poética, de modo a revisitar o diálogo Fedro, de Platão, com base na citação de Massa acerca da poesia de Drummond ("Sa poésie est au contraire un antidote, un poison, un repoussoir aussi” - Apud. NUNES, 2002d, p. 36):

Mas toda grande poesia não destila um veneno, que é, ao mesmo tempo, antídoto e
remédio? Não é o poeta e, sobretudo um poeta que conhece o poder de recusa e de
desprezo da palavra escrita, aquele que assume a função do pharmacon, no sentido
platônico - aquele que cura quando envenena e que envenena quando cura?
Antídotos, venenos e contrastadores, elementos da poesia drummondiana, também
se encontram entre os símplices da farmacopéia machadiana, e em ambas para
compor a substância, ora tóxica ora curativa, do humor (NUNES, 2002d, p.36 -
grifo do autor)

O humor drummondiano apareceu novamente como tema de um pequeno ensaio “Aceitação da noite” - do livro Crivo de papel (1998). Em diálogo, no primeiro parágrafo, com o texto de Antonio Candido - "Inquietudes na poesia de Drummond"35 - sublinha que o tom irônico do autor de "Poemas de sete faces" é o contraponto à “dificuldade de ser" do sujeito-lírico. Deste mote, teceu uma análise percuciente, de modo a ressaltar que o trágico e o jocoso se entrelaçam na composição poética de Drummond, em especial nos versos de “Cantilena prévia”36, de A falta que ama (Boitempo I).

O mesmo comentário pode ser conferido em "Meu caminho na crítica” (2005, p.9), em que ressaltou a associação “do pathos trágico da desindividuação dionisíaca com o

\footnotetext{
${ }^{34}$ Cf. MASSA, Jean-Michel. A juventude de Machado de Assis (1839-1970) - Ensaio de biografia intelectual trad. Marco Aurélio de Moura Matos. Rio de Janeiro: Civilização Brasileira, 1971.

${ }^{35}$ Cf. Vários escritos. $2^{\text {a }}$ ed. São Paulo: Livraria Duas Cidades, 1977, p.93-122.

36 "Don don dorondondon/É o Castelo de Drummmond/que vai à penhora.//Don don dorondondon/É a soberba de Dummond/que vai-se embora./Don don dorondondon/É o prazo de Drummond/que termina agora.//É o prazo de Drummond/que ainda não termina./Din din Resta uma resina.//Din din Resta uma farinha/de substantivo, infra-som/de voz, na voz de Drummond?//Don don don/O morto Drummond/sorri à lembrança/de estar morto (don)/alva não-consciência/(din) de maior ciência.//Dindon dorondin din/O que sabe agora/não o diz Drummond.//Sabe para si./Sabe por si só./Sabe só, sem som./É de rinfonfon./É sem cor nem tom./É completo.É bom.”(ANDRADE, Carlos Drummond de. Boitempo \& A falta que ama. 2ªd. Rio de Janeiro: Sabiá, 1973, p.177-8)
} 
entendimento sarcástico da finitude humana”, como resultado do humor que, no poeta mineiro, apareceu consubstanciado à reflexão.

\title{
1.1.8. João Cabral de Melo Neto
}

A relação reflexiva, aliás, que aproxima a Poesia da Filosofia, de acordo com Benedito Nunes (2000; 2005), nunca é direta e, sim, transversal, como na obra de João Cabral de Melo Neto.

No autor pernambucano, Nunes também observou a faceta do humor de A Educação pela pedra (1966) e apontou as intenções da sátira e da ironia nos versos que despontam amargos, objetivos, a denunciarem o absurdo das situações, da existência. Em "A máquina do poema”, no Dorso do tigre (1976), considerou que a aparente indiferença com que Cabral fala das coisas, reforça a tendência ao sarcasmo, a uma verve impiedosa:

\begin{abstract}
Esse indiferentismo no revolvimento das coisas, no descrever os seus avessos e enfatizar os seus contrastes, assinalado por Bérgson em "Le Rire", tem, como bem viu o nosso João Ribeiro, um fundo sentimental, que a "evidência obtida pela aniquilação" neutraliza intelectualmente. O humor de João Cabral conhece todas as asperezas da sinceridade intelectual. Passando pelo grotesco, que lhe dá a tônica para a impiedade da sátira, chega ele a proporcionar-nos aquele extremo da amargura virulenta em Swift, que o absurdo instiga, e à luz do qual tudo se torna sério e risível ao mesmo tempo. (p.272)
\end{abstract}

Tal interpretação igualmente foi defendida em João Cabral de Melo Neto (Ed. Vozes, $1974^{37}$, p.166 a 171), livro em que Benedito Nunes apresentou uma pesquisa exaustiva sobre o poeta, com nota biográfica, antologia dos principais textos, bibliografia de e sobre Cabral e uma introdução crítica que analisou, além dos poemas, o ensaio “Joan Miró”, a conferência “Poesia e Composição - A inspiração e o trabalho de arte”, apresentada por Cabral no Clube de Poesia de São Paulo (1952) e a tese "Da função moderna da poesia", feita para o Congresso Internacional de Escritores, por ocasião do IV Centenário de São Paulo.

Neste estudo, o percurso da poesia de Cabral foi revisitado pelo ângulo de uma fenomenologia que explorou cada teia de versos, sem esgotá-la, e permitiu perceber o lado esquivo do lirismo do escritor pernambucano, seu elevado domínio reflexivo na elaboração poética e as influências do tom prosaico de Drummond, da plasticidade de Joaquim Cardozo e do visionarismo de Murilo Mendes. (p.33)

\footnotetext{
${ }^{37}$ Esta obra é parte da Coleção Poetas Modernos do Brasil/1, orientação e coordenação de Affonso Ávila. A $1^{\text {a }}$ Ed. é de 1971; no prelo, uma nova edição, revista e ampliada, sairá pela Editora da Universidade Federal de Brasília.
} 
No artigo “João Cabral: Filosofia e Poesia” (Colóquio Letras, n¹57/158, jul/dez 2000), cujos apontamentos críticos foram reescritos em "Meu Caminho na crítica” (2005), Benedito Nunes condensou o processo da poética cabralina em três pontos: o primeiro, desde Pedra do Sono (1942), é o resultado de um "trabalho de arte", de ascese que dispensa o psicologismo com a utilização de substantivos concretos e séries temáticas, a partir de Duas águas (1956), que cria um léxico comparativo.

O segundo, a transferência de qualitativos das coisas humanas para as naturais, e viceversa, por um processo contínuo de vocábulos-imagens que se sucedem nos versos descritivos. No poema “O vento no canavial”, por exemplo, o canavial é apresentado como "um mar sem navios, / papel em branco de escrita”, (...) “como um grande lençol/sem dobras e sem bainha"38.

Por fim, notou que, na poesia de Cabral, a linguagem busca um real perceptível, longe de qualquer introspecção; por isso é didática, “congregando lições de inconformismo numa pedagogia da palavra ou numa educação pela pedra”. (NUNES, 2005, p.9)

Interessante destacar que, entre as questões que Nunes fez a João Cabral de Melo Neto, publicadas nos Cadernos de Literatura Brasileira (Instituto Moreira Salles, 1996), ao citar o poema "Coisas de cabeceira” ${ }^{\text {,39 }}$, vislumbrou certo traço memorialístico, proustiano, na poesia cabralina.

Semelhante observação foi descrita em “João Cabral: Filosofia e Poesia” (Colóquio Letras, $n^{\circ} 157 / 158$, julho/dezembro, 2000) e retomada em “Meu caminho na crítica” (2005). Nestes textos, enfatizou que, em A Escola das Facas, Agrestes e Crime na Calle Relator, a recorrente tematização do tempo pelo poeta é o resultado do movimento "de ida e volta dos nomes às imagens e das imagens às coisas” (2000, p.41) e da marca da materialidade espacial ou plástica das imagens em analogia com o espaço da pintura ou da escultura.

\footnotetext{
${ }^{38}$ MELO NETO, João Cabral de. Obra Completa. Rio de Janeiro: Ed. Nova Aguilar S.A ., 1995, p.150.

${ }^{39}$ COISAS DE CABECEIRA, RECIFE "Diversas coisas se alinham na memória/numa prateleira com o rótulo: Recife./Coisas como de cabeceira da memória,/a um tempo coisas e no próprio índice;/e pois que em índice: densas, recortadas,/bem legíveis, em suas formas simples." COISAS DE CABECEIRA, SEVILHA "Diversas coisas se alinham na memória/numa prateleira com o rótulo: Sevilha. Coisas, se na origem apenas expressões/de cigano dali; mas claras e concisas/a um ponto de se condensarem em coisas,/bem concretas, em suas formas nítidas.” (MELO NETO, João Cabral de. Obra Completa. Rio de Janeiro: Ed. Nova Aguilar S.A ., 1995, p.337 e p.344.)
} 


\subsubsection{Fernando Pessoa}

O racionalismo de João Cabral de Melo Neto possui, segundo Nunes (1974, p.18), pontos em comum com o de Fernando Pessoa, pois, em ambos, a obra poética é sempre exterior, reporta-se ao destinatário, ao Outro.

Não obstante, para o poeta português, no convívio com o Outro, o permanente desdobra-se em diferentes linguagens - Alberto Caeiro, Ricardo Reis, Álvaro de Campos, Bernardo Soares - e é um modo de se estabelecer um diálogo consigo e com o mundo para tentar configurar plausíveis formas de existência, por meio das quais há uma trama entre o subjetivo e o objetivo, a sensibilidade e o pensamento. (NUNES, 1976, p.220)

Em diversos momentos, como O dorso do tigre (1976), e variados artigos, por exemplo, "Poesia e filosofia na obra de Fernando Pessoa” (Colóquio Letras, $n^{\circ}$ 20, julho, 1974), Benedito Nunes assinalou que o fingir pessoano, artifício estético, conduz à criação de novas perspectivas de ser e de perceber o mundo. Assim, a expressão pessoana "fingir é conhecer-se" mostra que o "fingimento interessa ao poeta enquanto poeta, isto é, enquanto agente da poiesis, que cria ou dá forma na linguagem a uma possibilidade de ser. Esta é a sua liberdade e a sua verdade”. (NUNES, 1974, p.31)

Pessoa será mencionado, também, em “Meu caminho na crítica” (2005) como o autor que mais “brincou” (p.7) com o místico e com o mito. Sob as máscaras ou heterônimos, foi quem mais se aproximou, de modo lúdico, da Filosofia e, em especial, da Metafísica, pois, na criação artística, o fingimento é um índice que traz à tona o problema do conhecimento, do ser, das nossas verdades. Verdades que são ilusões, “mentiras vitais nietzschianas” (NUNES, 1974, p.30), já que o conhecimento é fictício.

\section{I.1.10. Os poetas Rainer Maria Rilke e T. S. Eliot}

As relações transversais entre poesia e filosofia também foram estudadas, particularmente, em dois poetas estrangeiros: Rainer Maria Rilke e T. S. Eliot. Ambos são comentados brevemente no texto "Meu caminho na crítica" (2005).

Para o professor paraense, tanto em Rilke quanto em Eliot, a filosofia aproxima-se da mística e a linguagem poética deles é entendida como "gnose intuitiva do real”. (2005, p.299)

Em O livro das horas (1899), o autor alemão concebe Deus dependente do homem, como já o considerava Meister Eckhardt, místico medieval. Este aspecto será aprofundado em 
Os cadernos de Malte Laurids Brigge (1910), juntamente com a compreensão da morte como “experiência vivida e amadurecida em cada homem”. (idem)

O Anjo, mensageiro do divino, articularia essas questões, de maneiras diferentes, mas com o mesmo propósito de concentrar no verso um peso existencial, em que, por meio dele, a poesia e a vida possam ser unidas. Tal vínculo possibilitaria ao poeta e ao leitor chegar a um estado de contemplação.

As elegias, noturnos musicais, com as quais o Anjo convive, diferenciam-se da morte, cujo traço característico é o do desconhecido, do estranho, do inóspito, da perda da habitação humana, dos desejos e do amor. Nas dez elegias, demarcadas por um tema - "o amor, a morte, o herói, a amante, os saltimbancos e os animais” - sobressaem imagens, "como mundo, espaço, destino e aberto”, próximas aos conceitos fundamentais das filosofias da existência. "Dentre eles, o aberto, correspondente ao termo conceptual Erschlossenheit (interstício, passagem) em Ser e tempo de Heidegger”. (idem)

Na obra de T. S. Eliot, a transversalidade da filosofia com a literatura ocorre, especialmente, no conjunto de "Waste Land", fragmentos morais e espirituais do mundo moderno, e de "Four Quartets”, composições filosófico-religiosas, síntese de "heranças mítica e mística do Oriente e do Ocidente”. (2005, p.300)

Esses poemas incorporam pensamentos de Heráclito, de São João da Cruz, de Platão, de Santo Agostinho, do Tao te King e do Bhagavad-Gita, em um emaranhado de culturas e de gerações. O escritor, para além de sua memória individual, apela para os vivos e para os mortos.

\footnotetext{
Nosso nascimento é uma espécie de morte. Morremos com os que agonizam e nascemos com os que morrem. A poesia constitui a cadeia dessa experiência letal. E é, ao mesmo tempo, a poesia que libera o homem da morte graças à função da memória, correlata ao circuito da História interligando passado, presente e futuro a uma parcela de eternidade conquistada em cada época. (NUNES, 2005, p.300)
}

Sobre T. S. Eliot pode-se destacar o texto de Benedito Nunes “A poesia confluente”, proferido no ciclo de conferências Poetas que pensaram o mundo, concebido pela Artepensamento em 2003, e realizado nos Centros Culturais Banco do Brasil (CCBBs) do Rio de Janeiro, de São Paulo e de Brasília. Em Curitiba, aconteceu no SESC da Esquina.

A reflexão foi publicada em 2005, em livro do mesmo nome do evento, organizado por Adauto Novaes. Nunes dedicou-a à memória de Angelita Silva, sua cunhada, tradutora dos “Four Quartets”. 
Em A terra desolada e Quatro quartetos foram ressaltadas as influências tanto ocidentais quanto orientais que o autor inglês recebeu, bem como realçada a matéria poética utilizada, fruto da "experiência dos sábios, santos e filósofos, (...) porque pretende fazer mais do que uma antropologia: quer escrever a justificação do homem, ou seja, uma antropodicéia”. (2005b, p.278)

A linguagem poética em Eliot, segundo o professor paraense, é "força de convergência”, em cuja órbita gravita o mito, a religião e a filosofia, em um confrontar-se que leva à dispersividade e ao fragmentarismo.

No mundo eliotiano, a História é também “expressão temporal da eternidade”. O além histórico é o ponto de encontro do temporal com o intemporal, marca da incidência da concepção platônica e agostiniana, intrínseca à sua poesia. Poesia esta em que lateja um "pensamento indagador, filosófico, dramatizando a existência individual e histórica interrogada”. (2005b, p.288)

\section{I.2. O ensaísmo crítico}

Em 1956, Benedito Nunes publicou, nos dias 5 e 12 de agosto, no "Suplemento Dominical” do Jornal do Brasil, um ensaio sobre o livro de Mário Faustino, O Homem e sua Hora (1955). O sucesso dessa analítica valeu um convite, da parte do então diretor do "Suplemento", Reinaldo Jardim, e por insistência do próprio Faustino, para que Nunes escrevesse regularmente para esse periódico. Mais tarde, Décio de Almeida Prado o levaria para as páginas do "Suplemento Literário" do Estado de S. Paulo, fomentado por autores ligados à Revista Clima $^{40}$, cuja estréia ocorreu em 31 de outubro de 1959, com um artigo intitulado "Panorama Cultural de 1959". Além desses, sua escrita se tornaria constante no Suplemento Literário de Minas Gerais ${ }^{41}$, criado por Murilo Rubião, por volta de 1965, e no jornal A Província do Pará ${ }^{42}$.

\footnotetext{
${ }^{40}$ Entre eles, Antonio Candido, responsável pela criação e pelo projeto do "Suplemento Literário”. Com relação à Revista Clima Cf. PONTES, Heloísa. Destinos mistos: o grupo Clima no sistema cultural paulista (19401968). São Paulo/USP: Tese de Doutorado, 1996.

${ }^{41}$ O prestígio deste Suplemento, que contava com jovens escritores e artistas plásticos chamados de "Geração Suplemento", pode ser conferido em WERNECK, Humberto. O destino da rapaziada: jornalistas e escritores em Minas Gerais. São Paulo: Cia das Letras, 1992.

${ }^{42}$ Cf. Bibliografia de Benedito Nunes.
} 
Esses Suplementos ${ }^{43}$ foram, sem dúvida, designativos da importância da chamada crítica jornalística $^{44}$. No hebdomadário do Rio de Janeiro, Nunes foi responsável pela seção de Filosofia, em que procurou apresentar as grandes linhas do pensamento moderno e contemporâneo e as possíveis influências gregas nas suas origens. Nesse espaço, houve a exposição da Fenomenologia de Husserl e a pretensão de discutir diferentes concepções do filosófico. Tais contrapontos também foram matérias de seus escritos no "Suplemento Literário” de O Estado de S. Paulo, bem como reflexões sobre a poética de, entre outros, Fernando Pessoa, João Guimarães Rosa, Clarice Lispector e João Cabral de Melo Neto.

Atualmente, o jornalismo literário é visto, por ele, com certa descrença, como afirmou em entrevista ao Caderno 2, do Estado de S. Paulo (1986), e no livro Conversas com filósofos brasileiros (2000a, p.77):

(...) Mais do que ver diferenças entre eles, eu tendo a ver diferenças entre esses dois suplementos e os suplementos atuais, mesmo em relação àqueles que surgiram logo depois. A distância é muito grande, hoje em dia obriga-se a escrever tantas páginas e tantas linhas sobre "fulano de tal". É quase uma resenha, uma recensão - como dizem os portugueses. Enquanto que, naquela época, o Jornal do Brasil, por exemplo, publicava artigos enormes, de dez, doze, até quinze páginas. O Estado de S. Paulo também, mas era muito mais norteado pelo Décio, que gostava de fazer edições temáticas. Certa vez, fez uma edição sobre Kafka, e pediu para cada qual escrever sobre um aspecto da obra desse autor - foi muito interessante. Havia uma liberdade na imprensa, que aceitava até mesmo matérias que não eram encomendadas. Se eu tinha escrito na gaveta, podia mandar para um desses jornais. O Jornal do Brasil publicava "Poesia e experiência", e outras seções, em páginas inteiras. Havia também uma seção chamada "Livro de ensaio", que era uma página grande subdividida em pequenas seções, como se fossem páginas de um livro. A intenção do jornal era que seus leitores recortassem essa página e fizessem um caderno. Uma vez escrevi um trabalho que foi publicado em cinco páginas inteiras, sobre um assunto que hoje é inabsorvível: o pensamento de Sócrates.

\section{I.2.1. Clarice Lispector}

Em decorrência de seu trabalho na imprensa, publicou seu primeiro livro - $O$ mundo de Clarice Lispector (1966), editado em Manaus com prefácio de Arthur Cézar Ferreira Reis -, reunião de artigos restritos a quatro obras da autora: Perto do coração selvagem (2a.

\footnotetext{
${ }^{43}$ A respeito da importância histórica e cultural do "Suplemento Dominical" do Jornal do Brasil Cf. CHAVES, Lilia Silvestre, Mário Faustino: uma biografia. Belém: Secult; IAP; APL, 2004, p.249-263. Sobre o "Suplemento Literário" d' O Estado de S. Paulo Cf. WEINHARDT, Marilene. O suplemento literário d' O Estado de S.Paulo -1956-1967: subsídios para a história da crítica literária do Brasil. Brasília: Minc, Instituto Nacional do Livro, 1987, 2 volumes; e LORENZETTI, Elizabeth de Souza. Do artístico ao jornalístico: vida e morte de um Suplemento - Suplemento Literário de O Estado de S. Paulo (1956 a 1974). São Paulo/USP: Dissertação de Mestrado, 2002.

${ }^{44}$ No artigo “Ocaso da literatura ou falência da crítica?” (1999a, p.16), Benedito Nunes cita, ao falar da crítica jornalística, o reviewer de Afrânio Coutinho. No caso, trata-se da distinção que este fazia entre o crítico "profissional especializado na análise, interpretação e julgamento da obra de arte literária, não pertencente a nenhum tempo determinado porque é sempre sua contemporânea" e o "reviewer", "jornalista, trabalhando sobre um tipo específico de notícia, o livro do momento”. Cf. Da crítica e da nova crítica, p. 76.
} 
Edição, 1963, Livraria Francisco Alves), Laços de família (1960, Francisco Alves), A maçã no escuro (1961, Francisco Alves) e A paixão segundo G. H. (1964, Editora do Autor). Esses mesmos textos foram editados, mais tarde, sob o título "O mundo imaginário de Clarice Lispector” na obra O dorso do tigre de 1969.

Em “Dona Clarice”45, de Dois ensaios e duas lembranças (2000b), Nunes explicou que principiou a leitura da escrita de Lispector pelos contos de Laços de Família (1960). No entanto, foi com A paixão segundo G. H. (1964), que "os laços da sedução literária e filosófica a ela me amarraram”. (p.43)

Para ele, interessava, naquele momento,

focalizar tão-somente certos temas e situações, constantes em Clarice Lispector, e que podem ser melhor compreendidos à luz de categorias comuns à filosofia da existência. Trata-se de uma recomposição temática do mundo de Clarice Lispector, a partir dos dados fundamentais que nos forneceram aqueles temas e situações. Preocupamo-nos mais em caracterizar a atitude criadora da romancista, e a concepção-do-mundo, marcadamente existencial, que com essa atitude se relaciona, do que em analisar a estrutura da criação literária propriamente dita. (Nunes, 1966, p.11-2)

Entre o livro de estréia e o posterior, Leituras de Clarice Lispector (em 1973, da coleção Escritores de Hoje da Editora Quíron de Nelly Novaes Coelho), corrigiu-se do que chamou de exagerada “dose da náusea sartriana”46 (NUNES, 2000b, p.44), e, junto com $O$ drama da Linguagem (Ática, 1989), a relação entre Filosofia e Literatura tornou-se mais nítida, como explicou no ensaio "Filosofia e Literatura” do livro No tempo do niilismo e outros ensaios (1993):

(...) o primeiro risco a evitar é a busca de conceitos instrumentais na filosofia para o exercício de uma pretensa Crítica Filosófica, que tentaria estudar a obra como a ilustração de verdades gerais. No primeiro estudo que escrevi sobre Clarice Lispector caí na sedutora armadilha dessa Crítica redutora, cujos passos exegéticos, muito esquemáticos, partem de uma analogia. Sobressaem nos contos e romances dessa autora graus de reflexividade dos personagens, que se enquadram nas categorias existenciais de mundo, inter-subjetividade conflitante e náusea. Logo, bastaria elaborar a analogia para extrair da narrativa de Clarice Lispector uma conceptualística existencial ou, mais particularmente, existencialista. Assim, nesse primeiro estudo, intitulado $O$ mundo de Clarice Lispector, apresentei a ficção da romancista de A paixão segundo $G$. $H$. como uma ilustração do pensamento sartriano. Eis o parco rendimento - ou rendimento nulo? - da Crítica desenvolvida como paráfrase filosófica. A ficção mesma da romancista, com seus procedimentos peculiares, da construção dos personagens ao aparato de sua linguagem, segundo a ligação característica entre a história e o discurso que nessa ficção se efetua - tudo isso, que é propriamente literário, era como que suprimido e eliminado em proveito

\footnotetext{
45 A amizade com Clarice Lispector é apresentada com extrema delicadeza nesse texto, em que os fatos da memória são revividos e expostos de modo a privilegiar a oralidade, o tom de confissão.

${ }^{46}$ Luiz Costa Lima, em Por que literatura? (1969, p.108), já apontava uma interpretação divergente de Nunes quanto à questão da náusea sartreana.
} 
do "substrato filosófico" da narrativa. Nos estudos posteriores, pude, felizmente, corrigir essa distorção, sob o foco prioritário da narrativa literária ajustado ao primado da consciência individual que marca o plano da criação mimética em Clarice Lispector. O "substrato filosófico" não é, de modo algum, independente desse plano. (p.197-8 - grifos do autor)

A obra de Clarice Lispector mereceu por parte de Nunes uma atenção constante. Além de conferências, congressos, palestras ${ }^{47}$, foi coordenador da edição crítica de $A$ paixão segundo G. $H .^{48}$ e responsável por inúmeros artigos; entre eles, pode-se destacar “A paixão de Clarice Lispector” (1982) ${ }^{49}$, “A paixão de Clarice Lispector” (1987) - texto com o mesmo nome, mas abordagem diferente -; “A narração desarvorada” (2004), que ampliou as reflexões expostas em “Clarice Lispector ou o naufrágio da introspecção” (1989a) e “Os destroços da introspecção” (1998b).

No primeiro texto, Nunes destacou o papel do livro A hora da estrela (1977), de Clarice Lispector, como aquele que possui o traço direcional do processo de criação com base no qual se pode estabelecer a unidade de coesão dos outros escritos em uma só obra.

Em A hora da estrela, o emaranhado de três histórias - o da moça nordestina (Macabéa), a do narrador interposto (Rodrigo S. M.) e a da própria narrativa - mistura-se a um novo agente narrador: a própria autora que, ao retirar a máscara de romancista, se assume como personagem.

\footnotetext{
${ }^{47}$ A mais recente aconteceu na III FLIP - Festa Literária Internacional de Parati - em 07 de julho de 2005. Clarice Lispector foi a autora homenageada no evento e Benedito Nunes participou de uma mesa de debates composta por Marina Colassanti e Vilma Arêas, com mediação de Lícia Manzo. Nunes comentou sobre uma das questões que a própria Clarice se colocava: o porquê e para que narrar e ressaltou que escrever, para ela, era como se fosse um tormento - daí a busca pelo silêncio - e uma condenação.

${ }^{48}$ Paris/Brasília/Florianópolis: Association Archives de La Littérature Latino-Américaine, des Caraibes et Africaine du XX Siècles/Conselho Nacional de Desenvolvimento Científico e Tecnológico CNPq/UNESCO/Editora da Universidade de Santa Catarina, 1988. Na verdade, segundo ele, "uma edição atípica, porque não havia originais do livro. (...) Infelizmente, eles estão perdidos, ao que parece para sempre. Tentei localizá-lo nos arquivos da extinta Sabiá, que primeiro editou o livro, mas não tive sorte. Têm um destino enigmático. A Clarice talvez tenha, não digo que motivado isso, mas pelo menos ajudado nesse desaparecimento. Ela foi uma escritora que não tinha grande estima pelos originais. Uma vez o texto publicado, não se interessava mais pelo que tinha escrito. (...) Para compensar, a Casa de Rui Barbosa me ofereceu para consulta os originais de um conto de Clarice, 'A Bela e a Fera', um dos últimos que escreveu. Nós o reproduzimos na edição crítica de G. H. e pudemos assim mostrar a maneira entrecortada de escrever que Clarice cultivava. É como se ela escrevesse por fulgurações. O confronto do original com o texto definitivo mostra com muita clareza esses movimentos dentro de sua escrita". (Entrevista a José Castello, O Estado de S. Paulo, Caderno 2, 1983, www.secrel.com.br/jpoesia/castel06.html. Acesso em $1^{\circ}$ de março de 2003).

${ }^{49}$ Este texto foi uma conferência pronunciada por Nunes por ocasião do $10^{\circ}$ Aniversário do Conselho Estadual de Cultura de Belém. Foi publicado no Suplemento Cultural do Diário Oficial de Belém, Pará, em 22 de fevereiro de 1982.
} 
Ao analisar essa questão do narrador e da narrativa, Nunes acabou por fazer uma reflexão sobre o romance e os limites da ficção contemporânea, da qual a escritura clariceana se tornou um exemplo.

Segundo ele, em Clarice há sempre as indagações: por que narrar? O que narrar? Como e para que narrar? Tais interrogações são as mesmas do narrador, que fundamenta a ficção ao integrá-las à sua matéria ${ }^{50}$.

São as possíveis respostas a essas questões a tônica do seu artigo. Com relação à primeira pergunta, Nunes explica que o porquê narrar nunca é puro. Sempre inseparável de um propósito expressivo, o que impele o dizer em Clarice Lispector se desata do imperativo de contar histórias, do ethos propriamente dito, que origina o novelesco. A intenção do dizer exige da escritora uma nova lírica no uso da linguagem.

Perto do coração selvagem (1944), O lustre (1946) e A cidade sitiada (1949), seus primeiros romances, já não são novelescos, assim como os seus últimos textos - Água Viva (1973) e A hora da estrela (1977) - negam a forma tradicional do romance do século passado. Seus contos, quase sempre sem enredos, tornam-se impossíveis de serem recontados, já que perderam a oralidade da fábula: “a história que encerram, encerra-se por sua vez numa experiência subjetiva”. (1982, p.4)

São narrativas compostas de pequenos momentos, experiências constitutivas do “tempo vivido da duração”, mas que permitem vislumbrar uma "célula do novelesco”, da qual se origina uma espécie de "narrativa proteiforme”, de improviso, como em Água Viva. Nesta obra, os temas do tempo, da morte e de Deus ocorrem semelhante à variação musical; ora se associam ora se modificam.

A pergunta - o que narrar? - encontra sua solução ao considerar-se essa circunstância extrema:

Não há matéria privilegiada para o narrador: galinha ou ovo, olhar de fera, moça nordestina ou raiz de árvore tudo pode entrar na substância impura da ficção. Ela é história que se desdobra em histórias, comentário reflexivo, visão indagadora ou meditação visual detida nas coisas, tentando captar-lhes o modo de ser para inscrevê-las na matéria fugidia da palavra escrita, e tornando-se um jogo da linguagem praticado com a seriedade de uma especulação intelectual. (1982, p.5)

\footnotetext{
${ }^{50}$ Essas mesmas questões são revistas no texto “A resposta de Clarice”. In: Clarice Lispector: a hora da estrela. [curadoria de Ferreira Gullar e Julia Peregrino] São Paulo: Museu da Língua Portuguesa, 2007, p.54/55;56/57;58/59. [Catálogo da exposição realizada em São Paulo, de 24 de abril a 2 de setembro de 2007].
} 
O “jogo de linguagem” a que se refere tem o sentido poético de movimento das palavras, sem o objetivo da comunicação propriamente dita. Entre o significante e o significado abre-se um hiato de silêncio; ponto contemplativo, indizível, um convite para que o leitor possa ter uma postura receptiva diante do objeto sobre o qual se explora. Clarice Lispector, nos seus romances, busca atingir esse intervalo de silêncio, do qual $A$ maçã no escuro (1961) é um exemplo ímpar.

Tudo pode, pois, ser narrado, mas se sabe que é para o inenarrável que tudo termina. Assim, a questão “como narrar?” pode ser respondida pelo "improviso verbal”, pelo “exercício existencial” revelador de uma linguagem despojada, sem a preocupação de um estilo, tal qual A paixão segundo $G$. $H$. Nesta, a busca pela limpidez do verbo conduz a sua escrita ao uso da palavra crua, seca, árida.

Neste ponto, “para que narrar?” serve para pôr em relevo a "tessitura do viver”, para defender a natureza humana contra a qualidade de alienação que a sociedade lhe impôs, para clamar "ao cerne da existência - eis a ética do romance e do conto, ao mesmo tempo finalidade estética da ficção”. (p.6)

A ficção só cumpre essa função quando se origina de uma escrita transgressora em um contato único e singular com a realidade por meio da linguagem.

Na visão de Nunes, o escrever de Clarice pode ser comparado a um pescador que "lança o anzol de suas frases entre as coisas fugidias” (p.6). Nesta pescaria, não há vitória; o ato da escrita, de "finalidade sem fim", culmina com o fracasso da linguagem. No entanto, sua escrita possui a força da paixão, da paixão pela linguagem em que a vida de Clarice Lispector se resumiu.

Aliás, a paixão pela linguagem, a "força da escrita”, termo que Nunes acrescentou de "força de leitura"51, de Barthes, é o cerne do texto "A paixão de Clarice Lispector” de 1987. Para ele, A paixão segundo G. H. (1964), de Clarice Lispector, é uma obra passional, em que a autora "mergulha em veios arqueológicos, em camadas afetivas culturalmente soterradas da sensibilidade humana”. (p.269)

O ensaio foi dividido em três partes: na primeira, comentou acerca das questões históricas e culturais da paixão. Depois, dissertou sobre o conjunto dos escritos de Clarice Lispector para, por fim, investigar particularmente o livro de 1964. Nesta investida,

\footnotetext{
${ }^{51}$ Cf. BARTHES, Roland. Bruissement de la langue (Essais Critiques, IV). Paris: Seuil, 1984, p.323.
} 
aproximou a "paixão da escrita”, que se sobressai em A paixão segundo G. H. (1964), a Grande Sertão: veredas (1956), de João Guimarães Rosa.

Em ambas, há o tema do erotismo: no de Guimarães, no entanto, o amor é entendido como Agapé e Charitas cristãos. Há uma forma épica de narrativa, na procura de Deus por Riobaldo. O romanesco, especialmente o mito do pacto com o Diabo, une-se à ação e sobrepõe-se ao místico. O amor em conflito de Riobaldo por Diadorim e Otacília desvenda o sagrado.

No livro de Lispector, o romanesco reúne-se ao místico pela "introspecção vertiginosa”, pelos sentimentos contraditórios. O sagrado é desvendado por um só "amor conflitivo".

Na visão de Nunes, “a paixão de Riobaldo não é a de Guimarães Rosa, mas, sob a paixão de G. H., estremece, transfundida, a paixão de Clarice Lispector”. (p.279)

As duas obras, por trajetórias distintas, ofereceram ao leitor “momentos de verdade”. A paixão de G. H. complementar-se-á em A hora da estrela (1977), na proximidade da narradora com Macabéa. Esta identificação, este novo “momento de verdade”, faz a paixão de Clarice Lispector tornar-se compaixão; o pathos solitário, simpatia como "padecimento comum”: a união in extremis da narradora com a anônima personagem nordestina.

Já no estudo de “A narração desarvorada” (2004b), ressalta-se uma análise minuciosa das principais criações artísticas clariceanas, que Nunes dividiu por fases de recepção. A primeira, iniciou-se com Perto do coração selvagem (1943), romance cujo conhecimento da publicação ficou restrito aos críticos e escritores. Os contos de Laços de família (1960) marcaram a chamada segunda fase, já com uma maior aceitação nos meios universitários, o que provocou interesse para outros textos da autora: O lustre (1946), A cidade sitiada (1949) e A maçã no escuro (1961). O terceiro momento decorreu da surpresa causada pela A paixão segundo G. H. (1964) e, em particular, de dois livros - A hora da estrela (1977) e Um sopro de vida (publicado postumamente em 1978). Nestas produções resumiram-se os principais elementos norteadores da escritura de Lispector: “(...) o singular processo criador, centrado na experiência interior, na introspecção, nos estados da consciência individual”. (NUNES, 2004b, p.292)

Ao comentar essas ficções, destacou a inusitada construção narrativa, o fio desconcertante da composição dos personagens, o intenso fluxo verbal que abole a distinção entre prosa e poesia. 
Em “Meu caminho na crítica” (2005, p.296) retomou as observações feitas à narração de A paixão segundo G. H. (1964) para mostrar que, neste texto, há uma “contra-filosofia”, uma vez que o que está em jogo é o limite extremo da linguagem, a consciência aguda do ato da escrita como o conflito entre palavra e coisa, o silêncio como resultado desse embate. Assim, o mostrar se sobrepõe ao dizer, o silêncio às palavras, a intuição à frase. O poético, entrelaçado ao místico, "tal como Wittgenstein o entendia" ${ }^{2}$, expõe o fracasso da linguagem e exibe o indizível como expressão.

\section{I.2.2. Introdução à filosofia da arte}

É em virtude também de sua participação no Suplemento de O Estado de S. Paulo que Antonio Candido, então coordenador da Coleção Buriti, solicitou a Nunes contribuir com esta coletânea. Surgiram, assim, dois livros dedicados exclusivamente à filosofia: 1966, vol.7, Introdução à filosofia da arte e, em 1967, vol.18, A filosofia contemporânea. De 1967 é também Farias Brito, da Coleção Nossos Clássicos, da Agir.

A obra Introdução à filosofia da arte, que teve uma segunda reimpressão em 1989, constituiu-se em um primeiro estudo mais sistemático sobre o pensamento estético, revisitado do ponto de vista histórico-teórico, cultural e filosófico. Com esta abordagem analisou criticamente o fenômeno artístico e destacou o papel da Filosofia da Arte como reflexão, cuja finalidade é justificar a existência e o valor da Arte.

Foram expostas, assim, as principais tendências sobre as experiências estéticas de Platão a Aristóteles; de Plotino a São Tomás de Aquino; passando pelo fundador desta disciplina, Alexander Gottlieb Baumgarten; pela Crítica do juízo (1790), de Kant; pelas cartas Sobre a educação estética da humanidade, de Schiller; pelo idealismo de Schelling e Hegel; pelo intuitivismo voluntarista de Schopenhauer e Nietzsche; pelo intuitivismo vitalista de Bergson; pela filosofia das formas simbólicas, de Ernst Cassirer; pela teoria de Benedetto Croce; pelo naturalismo de Hippolyte Taine; pelo marxismo. Por fim, comentou sobre a perspectiva de uma revisão dos pressupostos históricos da Estética tradicional na investigação de Max Bense, na fenomenologia de Husserl, na analítica existencial de Heidegger, na teoria dos signos de William Morris e na filosofia da linguagem de Ludwig Wittgenstein. (1989, p.118-125)

52 Para o Wittgenstein do Tractatus, "sobre aquilo de que não se pode falar, deve-se calar". Cf. WITTGENSTEIN, L. Tractatus lógico-philosophicus. Trad. Luiz H.L. dos Santos. São Paulo: Edusp, 1994, p.281. 
Ainda no campo da Estética, outros trabalhos podem ser mencionados como contribuições às idéias sobre a essência e o papel da Arte: "Estética e Correntes do Modernismo” (1975) que, de certa forma, dialoga com "Educação artística e Filosofia da Arte” (1976) e “O pensamento estético no Brasil” (1978).

Quanto a este último, sua amplitude, inclusive como ensaio-base de "Historiografia literária do Brasil” [Crivo de papel (1998)], permite rever quais são os liames entre a Crítica, a Estética e, em particular, a historiografia. Serão, assim, retomados no segundo momento do trabalho, a fim de que sejam discutidos de forma mais pertinente.

\section{I.2.3. Estética e Correntes do Modernismo}

Em "Estética e Correntes do Modernismo”, o autor paraense delimitou o estudo sobre a Estética do Modernismo de 1922 a 1930. A palavra estética, no texto, apareceu empregada ora como especulação acerca das “condições da sensibilidade artística”, ora como “juízo de valor acerca da natureza e da função da arte, inclusive sob o aspecto particular de procedimentos e técnicas”. (p.39) A poesia é o foco central, pois nela vigoraram as renovações literárias e artísticas do movimento; renovações estas, que podem ser consideradas díspares e contraditórias, entrelaçadas que estão por correntes como o esteticismo metafísico de Graça Aranha, o Manifesto Pau-Brasil, o Verdeamarelo, o grupo espiritualista de Festa e a Antropofagia.

Após breve comentário dos ismos do começo do século XX - Futurismo, Expressionismo, Cubismo, Dadá e Surrealismo - que influenciaram direta ou indiretamente os nossos modernistas - os aspectos da estética moderna foram debatidos em três planos: dos valores estéticos propriamente ditos (suspensão do belo como princípio e ideal regulador); da obra de arte como tal, que ganha autonomia e perde em transcendência; dos procedimentos ou técnicas, como a justaposição ou montagem, em que elementos heterogêneos se relacionam sem conexões diretas entre si.

Em seqüência, analisou os trabalhos de Mário de Andrade e de Oswald de Andrade (p.45), importantes como perspectiva central do Modernismo, cujo trajeto prático e teórico de Paulicéia Desvairada e seu "Prefácio Interessantíssimo" a Pau-Brasil e seu Manifesto precursor, realizou o processo de transformação histórica das artes sob o prisma da estética moderna. 
Mário de Andrade, sobretudo com o "Prefácio”, foi o precursor da primeira linguagem da moderna poesia brasileira. Sua postura, próxima às idéias da vanguarda em geral e às de L'Esprit Nouveau, em particular, ajudou a definir os princípios estéticos que se ligaram à época moderna: o verso livre, a rima livre e a vitória do dicionário, a substituição da ordem intelectual pela ordem do subconsciente, a rapidez, a síntese e o polifonismo. (p.47)

A perspectiva estética central do Modernismo (p.50) pode ser resumida pela poética marioandradina, como imagens-choque, sintaxe interruptiva, dissonância do verso, que a obra de Oswald de Andrade, principalmente após Memórias Sentimentais de João Miramar (1924), complementou.

Tal aspecto, no Pau-Brasil, associado a uma interpretação da cultura brasileira, “constituiu um elemento de diferenciação das diversas tendências do movimento” (p.53); um processo de distinção ideológica do nosso modernismo de que a Antropofagia compartilhou. O Manifesto Antropófogo (1928), de Oswald de Andrade, em diálogo com a rebeldia surrealista, elaborou uma visão crítica da sociedade brasileira, “dentro da qual a arte constitui o veículo da revolta individual a serviço da transformação da vida e dos seus valores morais e políticos”. (p.53)

A antropofagia oswaldiana, apenas realçada neste ensaio, foi analisada de forma mais contundente por Nunes no livro Oswald canibal (1979).

\section{I.2.4. Oswald Canibal}

De saída, Nunes relembrou que as obras de Mário e de Oswald de Andrade, elas próprias consideradas uma vanguarda, dialogaram com os escritos representativos das correntes da Europa, apesar de suas variantes atitudes receptivas às mensagens teóricas e estéticas das “metrópoles européias”:

Numa visão global da vanguarda de 22, pode-se dizer que o grau de receptividade e de respostas a esses estímulos e mensagens esteve condicionado aos diferentes momentos da dialética interna do Modernismo, segundo a ordem de seus problemas estéticos, sociais e políticos. (NUNES, 1979, p.9)

O antropofagismo constituiu-se como um exemplo de tais momentos, discutido por Haroldo de Campos ${ }^{53}$ e por Heitor Martins ${ }^{54}$, autor contra o qual Nunes argumenta.

\footnotetext{
${ }^{53}$ Cf. CAMPOS, Haroldo. Uma poética da radicalidade. In: Poesia de Oswald de Andrade. São Paulo: Difusão Européia do Livro, p.50.
} 
Primeiro ressaltou, porém, a concordância com Martins quanto à identificação das linhas da antropofagia aos movimentos do Futurismo, Dadaísmo e Surrealismo. Também assentiu quanto à descrição que o ensaísta de Canibais Europeus e Antropófogos Brasileiros fez da importância da viagem à Paris de Oswald de Andrade, em que este procurou embeberse das obras literárias, do convívio com autores locais e com o “espírito inquieto” das vanguardas.

Essa “experiência por participação” (p.11), trazida para o nosso Modernismo, ajudou a disseminar a renovação artística, em um ambiente de rebeldia e de atrito criado conjuntamente pelos manifestos futuristas, pela teorização cubista e pelo humor do dada.

Foi Blaise Cendrars quem exerceu influência obre Oswald e o ajudou a entrar em contato com “a comunidade vanguardista de Paris”. É possível que este tenha conhecido o “Manifeste Cannibale”, de Picabia. O canibal pode ser descrito como uma imagem forte, onírica, de impulsos agressivos contra a “má-consciência burguesa” (p.13), já citada por Nietzsche - pensador que marcou a formação intelectual de Oswald - antes de Freud. Para Oswald de Andrade, o canibalismo, "semáfora” da condição humana, fincou-se no entrecruzamento da Natureza com a Cultura.

Encontra-se aí o ponto de divergência de Nunes com Martins. Enquanto este reduziu a antropofagia de 1928 a uma mera divulgação do canibalismo europeu, aquele propagou que Oswald de Andrade não copiou os canibais da Europa, bem como negou a explicação causalista dada por Heitor Martins para o aparecimento do canibalismo oswaldiano.

Neste sentido, Nunes apontou a incongruência de uma história da literatura que não leva em consideração que as influências, “quando profícuas, equivalem a um sistema de confluências, dentro do processo comunicativo que se chama história da literatura ${ }^{55 » .(p .15)}$

A imagem do canibal faz parte de um repertório comum; saber como e quanto Oswald aproveitou das experiências vanguardistas da época foi o que levou Nunes a dividir sua reflexão em três momentos: no primeiro, situou Oswald de Andrade e sua obra diante dos signos da primitividade; em seguida, mostrou que o Manifesto Pau-Brasil (1924) e o Antropófago (1928) são peças-chave da poética oswaldiana e da própria dialética do

\footnotetext{
${ }^{54}$ Cf. MARTINS, Heitor. Canibais Europeus e Antropófagos Brasileiros (Introdução ao estudo das origens da antropofagia), I e II. In: Minas Gerais, Suplemento Literário, Belo Horizonte, 9 e 16 de nov. de 1968.

${ }^{55}$ No texto "Historiografia literária do Brasil”, em Crivo de Papel (1998), Nunes retoma esta questão e a discute mais amplamente. Irei comentá-la no segundo capítulo.
} 
Modernismo. Por fim, discutiu o Modernismo brasileiro da fase da receptividade ao espírito das vanguardas européias que o caracterizou.

Na sua análise, Nunes expôs a atitude antropofágica oswaldiana como desmistificação da história escrita, oposição ao nacionalismo tradicional, como repúdio à sociedade patriarcal e “devoração” cultural dos conceitos europeus:

O inconformista Oswald, apegado à antropofagia, por ele formulada em 1928 no Manifesto, e reformulada em 1950 em A Crise da Filosofia Messiânica - inquieto Oswald que escolheu o Matriarcado, não poderia tratar da marcha das utopias, sem que o seu próprio pensamento não se fizesse utópico para acompanhá-la. (p.77)

Ainda sobre Oswald de Andrade, é relevante lembrar a resenha ${ }^{56}$ de Nunes à obra Ponta de lança (2004c). Tal livro reuniu artigos e ensaios polêmicos do autor de Marco zero, escritos entre 1943 e 1944, no calor da guerra. Desde 1930, ao assumir uma posição política marxista, Oswald afastou-se da experiência antropofágica, mas “conservara a rebeldia intelectual e a pureza do libertarismo, que depois o levariam de volta a essa experiência”. (p.7)

A “contramarcha” de suas idéias apareceu nos textos “Destino da técnica” e “Aqui foi o Sul que venceu”, sobre os quais o crítico paraense apontou contradição no pensamento oswaldiano, pois, como marxista, "seria herético confiar, como ele confia, no espontaneísmo regenerador da técnica, guindada à função de agente dialético puro, absorvendo e eliminando a função messiânica do proletariado”. (p.11)

Já em “Sobre o romance”, elogiou a reflexão que Oswald faz sobre a progressão do gênero, distante de uma deturpada crítica ideológica, pronta a separar o romance burguês do proletariado.

Com relação ao Modernismo, Oswald o relacionou com 1789: a Semana de Arte Moderna e a economia cafeeira, nos séculos XIX e XX, seriam episódios políticos de uma evolução histórica, como a conspiração de Vila Rica para a economia do ouro, no século XVIII.

Semelhante comparação, notou o professor do Pará, Mário de Andrade havia feito em “O movimento modernista”, nos Aspectos da literatura brasileira (s/d): o espírito romântico relacionou-se com a Inconfidência Mineira, assim como o espírito modernista, com a revolução de 1930.

\footnotetext{
${ }^{56}$ Publicada em O Estado de S. Paulo, São Paulo, 21 de novembro de 1971, Suplemento Literário, p.1 e como prefácio em ANDRADE, Oswald. Ponta de Lança, 5ª ed. São Paulo: Ed. Globo, 2004.
} 


\title{
I.2.5. Educação artística e Filosofia da Arte
}

Com relação à “Educação artística e Filosofia da Arte” (1976), Nunes discorreu sobre o valor da educação artística entendida como pertencente de fato e de direito à Filosofia da Arte. De fato, porque a Filosofia da Arte defronta-se com problemas pedagógicos aos quais se percebe ligada por um vínculo histórico antigo, originário; de direito, pois há no conceito de educação artística uma abrangência da natureza e do valor da arte.

A idéia defendida foi a de que a educação artística estaria compreendida em uma concepção adjetiva de arte, cuja função seria a de transmitir a experiência artística de forma a influir na formação do indivíduo ao integrá-lo a um ideal de cultura.

Para tal projeto, rememorou a conceituação de arte desde a filosofia grega até o século XX e realçou temas como “poiesis”, “mimese”, “juízo estético”, “experiência estética”, arte como “jogo formador e formativo". Neste sentido, entendeu o

\begin{abstract}
exercício da arte, adjetivamente concebida e praticada, uma espécie de ação extensiva e profunda que, ultrapassando o plano do mero cultivo das formas, do aprendizado de uma tradição ou da realização artística propriamente dita, alcance, à custa dos poderes despotenciados da poiesis que Platão temia, a eficácia de uma paideia. (NUNES, 1976, s/p.- grifos do autor)
\end{abstract}

\section{I.2.6. Filosofia Contemporânea}

O livro Filosofia contemporânea, escrito em 1967, foi tecido com a intenção de divulgar as várias modalidades do pensar hodierno. A última edição, revista e atualizada, data de 2004 e acrescenta um estudo sobre o Estruturalismo como método abrangente das ciências humanas, da noção de estrutura, e sobre a Hermenêutica nas suas diferentes concepções.

A expressão “filosofia contemporânea” refere-se: à trajetória de uma reflexão filosófica, esboçada ainda no século XIX, com o aparecimento de novas tendências; à herança ao pensamento moderno das idéias de Kant, Hegel e Marx; e aos autores extemporâneos às suas épocas - Kierkegaard e Nietzsche.

Neste caminho, abordou, ainda, o Realismo e o Pragmatismo de Peirce, William James e John Dewey. Na sua visão, esta última doutrina, apesar de esgotada como princípio, apresenta atitudes compatíveis com a filosofia contemporânea, como a primazia da ação sobre o conhecimento e a valorização da experiência humana.

Da contribuição de Bergson como pensador atual, enfatizou pontos essenciais que entrelaçam as filosofias da vida, a fenomenologia e as correntes existenciais: 1. a correlação 
entre intuição e reflexão, contrárias ao espírito de sistema; 2. a filosofia baseada na experiência concreta do ser humano; 3. a importância da vida interior, da consciência; 4. o tempo como eixo de uma nova metafísica, não-cartesiana.

Em seguida, tratou do historicismo de Dilthey, da Fenomenologia de Edmund Husserl, da Percepção de Maurice Merleau-Ponty e das Ontologias de Heidegger e Sartre.

Heidegger e a questão do ser, a analítica do Dasein, as filosofias da existência, a filosofia científica e o pensamento de Wittgenstein mereceram um longo capítulo. Heidegger e Wittgenstein são comentados de forma mais aguda, em um pensar que se confunde com as reflexões propostas pelos autores. Para Nunes, os dois são os filósofos de sua preferência ${ }^{57}$.

Em “Novas Correntes”, destacou o Estruturalismo e a noção de Estrutura, ao revisitar a antropologia de Claude Lévi-Strauss e a psicologia de Jean Piaget. A Hermenêutica de Gadamer, a Arqueologia e Hermenêutica de Michel Foucault e a Fenomenologia e Hermenêutica de Paul Ricoeur, na sua discussão sobre a narrativa, discurso e tempo, são resultados de ensaios já publicados que, neste livro, ganharam contornos mais definidos.

Os textos sobre Ricoeur, por exemplo, encontram-se em Narrativa, ficção e história (1988), com organização de Dirce Côrtes Riedel, resultado das exposições, comentários e debates orais do “Colóquio Narrativa: Ficção e História”, realizado de 25 a 27 de novembro de 1987, e promovido pelo Setor de Literatura Brasileira do Departamento VI do Instituto de Letras da UERJ.

Após a exposição de Benedito Nunes, denominada "Narrativa Histórica e narrativa ficcional”, houve as observações de Bento Prado Júnior com “A narrativa na psicanálise, entre a história e a ficção”, que acrescentou ao trabalho do professor paraense um aporte sobre a idéia de narrativa com vistas à interpretação psicanalítica, necessária para examinar as considerações de Nunes e de Ricoeur a respeito da interpenetração entre a narrativa histórica e a ficcional.

\section{I.2.7. O tempo na narrativa}

\footnotetext{
${ }^{57}$ Cf. entrevista feita por Tatiana Ferreira. Site www.ufpa.br/beiradorio/arquivo/beira27/notiacias/noticias6.htm. Acesso 17 de janeiro de 2005.
} 
Vale lembrar, também, a obra O tempo na narrativa (1995), assentada sobre a discussão fenomenológica do processo de narrar e da experiência temporal, com apoio na conceituação de Ricoeur sobre o enredo, reinterpretado à luz da idéia aristotélica de mímeses.

O mesmo tema serviu de análise em Filosofia contemporânea (2004), assim como a explanação que Nunes fez de Temps et récit (Paris, Seuil, t. I,1983; t. II, 1984; t. III, 1985), de Paul Ricoeur, a principal referência norteadora do ensaio de 1995:

\begin{abstract}
a narrativa, como forma de linguagem, é um equivalente simbólico da ação e do tempo humano correlato. Essa função simbólica alcançaria o seu maior grau de complexidade nos romances que tematizam o tempo, narram 'coisas do tempo'. Neles, as variações da ação, interiorizadas nuns, mítica ou historicamente amplificadas noutros, corresponderiam às variações imaginárias das relações temporais. Essas variações imaginárias, no mundo da obra, que reconfigura o mundo real, implicam um desvendamento das modalidades do tempo humano, como as que devemos ao romance moderno, de Proust a Guimarães Rosa, de Thomas Mann a Alejo Carpentier. (p.77-8)
\end{abstract}

Em O tempo na narrativa (1995), Nunes dirigiu-se ao leitor em vários momentos em um estilo machadiano, ao mesmo tempo didático e irreverente, e utilizou, como fio condutor de sua exposição, A montanha mágica, de Thomas Mann, para fundamentar suas ponderações sobre o tempo nas suas variadas modalidades narrativas.

O estudo abrangeu, também, da teoria dos gêneros clássicos de Lessing à concepção de um tempo plural, baseado na experiência de acontecimentos internos ou externos, na cultura, na vida social e histórica (p.23); do tempo do discurso e da história como técnicas narrativas à dinâmica do ato de ler (Iser), que caracteriza a dimensão do tempo fictício; dos tempos verbais na narrativa (Harald Weinrich) às correntes de pensamento filosóficas (Bergson, Husserl, Heidegger) próximas da literatura (p.56-72). Já no livro Tempo e História (1992), com organização de Adauto Novaes, em que diferentes autores refletem sobre a questão expressa no título, Benedito Nunes contribuiu com o texto “Experiências do tempo". Neste, teceu considerações sobre o ser temporal do homem, no pensamento de Heidegger em Ser e tempo, e discorreu sobre a questão da historicidade e da história como ciência, integrada à do tempo.

“Tempo e História”, por outro lado, é um subitem do capítulo "Fenomenologia e Hermenêutica - Ricoeur”, de Filosofia contemporânea (2004). Neste, o fato histórico é visto em uma amarra com um quase-enredo, quase-personagem e quase-acontecimento, que mantêm a "História ligada à narrativa, com a qual não pode romper inteiramente". O tempo 
histórico, ajustado ao tempo cósmico e ao tempo vivido, "replica, poeticamente, à semelhança da Ficção, uma aporia da temporalidade”. (p.207)

Ainda sobre a questão do tempo, Benedito Nunes é o responsável pelo discurso "O tempo dividido: Cosmos e História”, e pela Coordenação do Ciclo de Preleções A Crise do pensamento, realizado pelo Núcleo de Arte - NUAR - da Universidade Federal do Pará, em junho de 1993. Os textos produzidos foram, depois, organizados por ele e saíram, com edição da UFPA, em 1994.

Em “O tempo dividido: Cosmos e História” estudou as diversas categorias de temporalidade, com base na experiência prática, e considerou a relação entre tempo e história algo singular na identificação da gênese e do declínio das idéias de progresso e revolução, essenciais à consciência histórica moderna.

\section{I.2.8. Farias Brito}

O livro Farias Brito, da Coleção Nossos Clássicos, da Agir, reunião de trechos escolhidos das principais obras do filósofo cearense, completou, junto com Introdução à filosofia da arte e Filosofia contemporânea, suas publicações referentes à filosofia lançadas no ano de 1967.

Antes, havia publicado, na Revista do Livro (1964), um artigo em que já comentava as reflexões propostas pelo professor do Colégio Pedro II à investigação filosófica do seu tempo. Reflexões estas, porém, que careciam de uma “problemática objetiva, ligada às solicitações da realidade nacional (...) e que lhe propiciassem as vivências de que necessitava para a sua interpretação do Universo”. (p.149)

Não obstante, Nunes reconheceu nele seriedade, dedicação e capacidade de divulgação das correntes e tendências filosóficas da época. A edição de 1967 complementa e ajuda a entender as idéias defendidas por Farias Brito.

Benedito Nunes dividiu sua Apresentação de Farias Brito (1967) em dois momentos: no primeiro, explanou a situação histórica e localizou o pensamento de Farias Brito na geração dos primeiros anos da República no Brasil, quando novas idéias surgiram em confronto com antigas posições. Foram nas primeiras manifestações da literatura regionalista e em concordâncias com o bergsonismo, neotomismo, correntes vindas da Europa, que surgiu um espiritualismo "polêmico e inquieto, que reage às tendências anti-religiosas da Filosofia” 
(p.7-8) do século XIX. Contra as "doutrinas de dissolução” (materialismo e positivismo) ${ }^{58}$, a postura de Farias Brito, questionador da Escola do Recife, encontraria consonância com vozes como as de Jackson de Figueiredo, Alceu Amoroso Lima, Tasso da Silveira, Nestor Victor.

Para o autor da Finalidade do Mundo, a degradação moral e a desordem política da época tinham como responsáveis os relativistas e os materialistas, que esvaziaram o sentido metafísico e religioso do pensamento. À filosofia, pois, caberia resgatar uma integração do saber que combinasse os valores da ciência, da moral e da poesia, esta entendida em uma concepção ampla de ideal artístico.

No segundo, denominado "Estudo Crítico”, Nunes analisou suas principais obras e o conceito-chave de suas intenções expresso em uma "filosofia como atividade permanente do espírito”. (p.8)

Tal acepção, unida com o problema da finalidade do mundo, foram temas desenvolvidos por Farias Brito na trilogia escrita de 1895 a 1905 (Estudos de Filosofia e teleologia naturalista). A idéia da “filosofia como atividade permanente do espírito" seria mantida em $O$ mundo interior (1914), última fase de suas reflexões, e em Ensaio sobre o conhecimento, síntese final do seu trabalho, que não chegou a terminar.

Este "encadeamento circular de conceitos" proporcionou ao "pensamento de Farias Brito, tão dispersivo e hesitante quanto prolixo e retórico por vezes, certa unidade teórica” (p.10), que lhe garantiu traços de universalidade e de fundamentação racional.

Os primeiros ensaios, iniciados em 1895 com a publicação de Finalidade do mundo, tinham como objeto de investigação a filosofia moderna. Na segunda parte desta obra (1899), examinou a filosofia dogmática e da associação. Em $O$ mundo como atividade intelectual (1905), terceira e última parte, estudou a “consciência filosófica contemporânea”, em que enfocou a crise das teorias modernas como "a idéia do eterno retorno de Nietzsche e a filosofia crítica de Kant”. (p.12) Na Base física do espírito, ensaio de um conjunto de estudos originados de A Verdade como regra das ações, abordou as tendências e correntes da psicologia, do seu princípio às escolas experimentais de Tetens, Weber, Fechner e Wundt.

Para Benedito Nunes, Farias Brito viveu uma “curiosa contradição”: rejeitou uma religião organizada, no entanto, “entendia que é a falta de religião no pensamento moderno o vácuo histórico por onde irrompeu a crise social, superável pela ação de uma idéia

\footnotetext{
${ }^{58}$ A respeito da posição de Farias Brito, Cf. “O pensamento estético no Brasil” (1978, p.98-108).
} 
essencialmente religiosa, capaz de impregnar as almas, e de restabelecer, com a ordem social, o princípio da finalidade do mundo”. (p.12)

Apontou, ainda, lacunas na formação do filósofo do início do século, reveladas pela maneira como expunha os sistemas da filosofia moderna: Hegel foi visto superficialmente e Marx, indiretamente. De Nietzsche destacou, apenas, o conceito de eterno retorno. Não obstante, ele estudou, de forma mais profunda, Spencer, Haeckel, Comte, Büchner, Descartes e Spinoza. A filosofia bergsoniana foi assimilada em $O$ mundo interior, o que bastaria para “demonstrar a competência de Farias Brito como expositor, e, dentro das limitações do meio brasileiro, onde só recentemente Dilthey e Husserl começaram a ser conhecidos, a franca atualização de suas leituras filosóficas”. (p.15)

Na visão de Nunes, Farias Brito soube promover uma autêntica reflexão, o que lhe conferiu importância e significação para o Brasil e o consagrou como o "pioneiro da cultura filosófica entre nós”. (p.16)

De 1902 a 1909, Farias Brito viveu no Pará, onde, em 1903, tornou-se professor de Filosofia do Direito na então recém-criada Faculdade de Direito do Pará. Em sua homenagem, em 1973, a Universidade Federal do Pará deu seu nome à série reservada à publicação de obras de Filosofia e Psicologia, dentro da “Coleção Amazônica”.

É nesta “Coleção Amazônica” - série Farias Brito - que apareceram os Diálogos de Platão, com coordenação de Benedito Nunes e tradução direta do grego por seu tio, Carlos Alberto Nunes. São quatorze estudos, com uma Introdução Geral, a Marginalia, espécie de roteiro para conhecer o pensamento platônico e uma prévia de leitura de seus Diálogos.

No prefácio da $1^{\mathrm{a}}$ edição, Nunes ressaltou o ineditismo tanto da tradução, a primeira no Brasil, quanto ao fato de ser uma iniciativa de uma Universidade do Norte.

O trabalho do meu tio era monumental: ele escrevia à mão, datilografava e encadernava. Eu tenho todos os cadernos. Precisava de uma disciplina muito grande para realizar isso. Antes ele traduziu a Odisséia e a Ilíada de Homero, de que Mário Faustino gostava muito. Meu tio foi um dos meus grandes fornecedores de livros. Quase todo mês eu recebia um pacote de livros vindo de São Paulo, com romances, livros de filosofia. Por exemplo: a edição de 1921, que tenho de Kant, de Berlim, foi presente dele. A edição original de Schelling também. À la recherche du temps perdu, de Proust, na edição da Gallimard do tempo da Guerra, feita no Canadá em doze volumes, foi ele também que me forneceu.

Mas ele era engraçado, um pouco arcaizante. Ele sabia muito a respeito de Platão, de Antiguidade em geral, mas não prezava literatura moderna. Até os dramas que ele escrevia eram em versos. Eu não gostava, e ele sabia disso. A minha entrada no modernismo foi para valer. (NUNES, 2000a, p.73) 


\section{I.2.9. $O$ dorso do tigre}

Os laços da Literatura e da Filosofia seriam amarrados, em 1969, com a reunião de artigos publicados não só no órgão paulista, mas também nos periódicos Comentário, Revista do Livro e Suplemento Literário de Minas Gerais, entre 1962 e 1967, que compõem o livro $O$ dorso do tigre ${ }^{59}$, cuja segunda e última edição data de 1976.

Nesta coletânea, o exercício crítico expôs um diálogo com o pensamento de Heidegger, em travessia para o poético, em textos cuja dimensão reflexiva apontou para um arrazoar filosófico como forma de pensamento em jogo com o limite paradoxal e absurdo da existência (1976, p.11-25); a sua superação, que se iniciou com o sistema de Hegel, reinterpretado por Marx (p.17-25); a questão das utopias, entendidas como ucronias (p.27-35).

Singular debate foi promovido com a revisitação do conceito de metafilosofia, de Lefebvre (p.37-49), e de sua acepção de praxis (movimento da atividade produtora) em consonância com a poiesis (atividade criadora) e mimesis (reverso da praxis, conservação das estruturas, inércia após todo ato de criação), que corrigiu a razão dialética e estabeleceu vínculos com Sartre em La critique de la raison dialectique (1960).

O sentido da obra de arte para além da Estética, que se desenvolveu em A origem da Obra de Arte, de Heidegger (p.51-7), é complementado com o ensaio "Os círculos de Heidegger” (p.79-87), em que os pressupostos teóricos do pensador alemão, com base em Ser e Tempo, foram rediscutidos.

A ontologia de Heidegger, como ontologia da linguagem, também foi revista quando da aproximação da arqueologia das Ciências Humanas de Foucault (p.59-78), tal como é apresentada em Les Mots et les Choses (1966).

Nos estudos literários, destacou-se uma analítica de acentuado traço filosófico das obras de Clarice Lispector, Guimarães Rosa, Fernando Pessoa e João Cabral de Melo Neto sobre as quais, com exceção de Rosa, já comentei brevemente, mas que serão retomadas em momento oportuno.

\footnotetext{
${ }^{59}$ Em artigo do site da Revista Entrelivros, $O$ dorso do tigre é considerado um dos dez livros mais importantes da história literária brasileira. Cf. MUSSE, Ricardo. "A literatura brasileira em dez livros - do Barroco ao Modernismo, obras perfazem toda a história literária no país”. In: www.revistaentrelivros.com.br - Acesso em 10 de julho de 2006.
} 


\section{I.2.10. Diretrizes da Filosofia no Renascimento e $O$ universo Filosófico e Ideológico do}

\section{Barroco}

É também com base na filosofia que se sobressaem, por exemplo, os ensaios sobre o Renascimento - “Diretrizes da Filosofia no Renascimento” (1978b) -, e sobre o Barroco “O universo Filosófico e Ideológico do Barroco” (1983) ${ }^{60}$.

O primeiro é o resultado de um Ciclo de Conferências promovido pelo Museu Nacional de Belas-Artes (16 de junho a 18 de agosto de 1977). Após deliberar sobre o pensamento medieval e o seu processo de rompimento, Nunes traçou as linhas gerais da concepção renascentista do mundo, nascidas de tendências filosóficas adversas e de diretrizes diferentes que se complementam e que espelham as polaridades e os contrastes do próprio Renascimento.

Desta forma, examinou a relação do Renascimento com o Humanismo e com a criação artística, além de analisar o pensar filosófico da Renascença nos diversos domínios: da lógica à metafísica, da epistemologia à ética e à estética e da visão da Natureza como "totalidade espraiada no espaço infinito”. (NUNES, 1978b, p.76)

Quanto ao Barroco, dissertou sobre os seus desdobramentos histórico-ideológicos, a esfera artística - pintura, escultura, literatura - e o pensar filosófico em ressonância com a modernidade.

Em um texto mais recente - "Um triunfo Barroco na Selva Amazônica. Os Tristes, Brutos Índios de Vieira ou um Missionário Aturdido” (2000e) -, comentou sobre o Sermão da Epifania, do Padre Antônio Vieira, que o discursou, em Lisboa, no dia 6 de janeiro de 1662, após ter sido expulso do Pará. Nesse, Vieira comparou a missão dos missionários, que caminharam do Oriente para o Ocidente, “como a seguir a mesma ofuscante estrela dos Magos"; e a dos jesuítas, que foram, "sob o fulgor da imperial estrela das conquistas portuguesas” (p.23), ao Brasil adentro, ao encontro das gentes do Novo Mundo para evangelizá-las.

No Sermão, Vieira dirigiu-se aos índios com qualificativos como "bruto”, “vil”, talvez "num momento de irritação diante das dificuldades que se opunham ao seu apostolado mormente as que decorriam do forçoso aprendizado, sem livros, de tantas línguas, sem cujo conhecimento estar-lhe-ia vedado o acesso à alma indígena”. (p.24)

\footnotetext{
${ }^{60}$ Republicado em No tempo do Niilismo e outros ensaios, 1993, p.118-28.
} 
Para Nunes, Vieira não poderia qualificar de natural a sociedade indígena, a menos que se antecipasse aos Iluministas; nem poderia aceitar que a evangelização fosse uma tirania, “pondo à prova o entendimento e a memória dos índios. Entendimento e memória que não eram deficientes, como pensava Vieira”. (p.28)

Em seu exercício reflexivo, Nunes investiga, com igual rigor, a História, a Natureza e a Cultura.

Aliás, segundo Jean-François Nordmann (1999), a historicização é “um procedimento ou talvez o procedimento essencial do entendimento hermenêutico em Benedito Nunes”. (p.425) Em variados textos, esta representa uma via metodológica e filosófica essencial na compreensão das questões discutidas e "gera uma consciência viva da relatividade, da contingência, e, mais radicalmente, da facticidade e da arbitrariedade de nossas formas de encontrar e vivenciar o mundo”. (p.425)

\section{I.2.11. Casa, praça, jardim e quintal.}

A visão histórica do público e do privado e de seus correspondentes espaciais - a casa, o jardim e a praça -, foi o tema de um breve artigo intitulado "Casa, praça, jardim e quintal” (1994).

Em diálogo com o estudo de Nelson Saldanha, O Jardim e a Praça (um estudo sobre o privado e o público na vida social e histórica), Nunes fomentou a discussão sobre a crise da casa, da praça e do jardim, como a crise do mundo moderno.

O fio narrativo-dissertativo textual remontou desde o principio erat hortus bíblico à poesia de Manuel Bandeira - umas das “poucas tentativas, até agora, de definição do quintal nas letras brasileiras” (p.262) - de modo a passar pela agora grega; pela estética de Kant, para quem “o jardim é antes de tudo um quadro da natureza viva” (p.258); pela arte dos jardins na Estética de Hegel; e pelo clássico Raízes do Brasil (1982) de Sérgio Buarque de Holanda.

\section{I.2.12. A visão romântica}

O princípio histórico foi, igualmente, o foco do ensaio “A visão romântica” (1985). Seu ponto de partida foi a distinção entre o eixo psicológico e o histórico, implícitos no conceito de Romantismo; o primeiro, entendido como uma maneira de sensibilidade, e o segundo, como um movimento literário e artístico datado. 
A categoria psicológica, considerada como universal, traz o caráter da inquietude, da insatisfação permanente, do conflito interiorizado. Tais características, impressas nas artes, adquirem uma conduta espiritual definitiva e traduzem uma forma ou concepção do mundo. Concepção esta que afastou, do universo cultural, a literatura e a arte para transformá-las em instância singular de uma só atividade poética, "supra-ordenadora das correlações significativas da cultura, concomitantemente ligada à afirmação do indivíduo ao conhecimento da Natureza”. (p.53)

Segundo Nunes, o Romantismo pode ser entendido como uma reunião de correntes, até certo ponto autônomas, ligadas às diversas tradições nacionais.

A alemã (a partir de 1796) foi a primeira a possuir uma amplitude crítica e histórica da palavra romântico; a fortuna teórica desta passa a conotar um "estado da poesia e uma atitude em relação à literatura”. (p.52) Esta vertente originou-se de uma geração posterior ao Sturm und Drang, no clima universitário de Iena, no mesmo momento do Idealismo pós-Kantiano, em que se localizaram a metafísica do Espírito de Fichte e a metafísica da Natureza de Schelling. A escola alemã foi ligada ao classicismo de Weimar (Goethe e Schiller), à problemática schilleriana da poesia ingênua dos antigos e à da poesia sentimental dos modernos.

A visão romântica do mundo deve ser vista em separado da filosofia do Romantismo, calcada nos sistemas idealistas e nas doutrinas posteriores a Kant, com inclusão da teologia sentimental de Schleiermacher e o realismo mágico de Novalis. (p.52) Como fenômeno da história literária e da evolução das artes, ela pode ser “considerada como visão de época” (p.53), dependente do contexto sociohistórico e cultural determinado.

Conforme Nunes, as idéias da visão romântica do mundo originaram-se da oposição às do Iluminismo. Neste ponto, ao cotejá-las, em um panorama prismático, ele abordou as tendências “dispersas” e "heterogêneas” que se encontram na visão romântica.

\section{I.2.13. Um conceito de cultura}

Em 1973, na chamada “aula magna”, pronunciada no início dos cursos da Universidade Federal do Pará, o professor paraense trouxe à tona a reflexão sobre "Um conceito de Cultura”. Mais tarde, em 2004, esta produção seria publicada pelo Conselho Estadual de Cultura do Pará. 
Em tal alocução, explicou que o tema foi suscitado em razão da reforma universitária da época, que orientou a implementação do ciclo básico comum a todos os cursos. Este, assim, garantia uma maior flexibilidade curricular e destinava-se a "suprir as insuficiências de preparo intelectual do estudante recém-admitido, [para] orientá-lo na escolha da carreira (...) e 'propiciar elementos de cultura geral indispensáveis à plena formação individual e social do aluno"”. (2004d, p.5)

Com base nestas considerações, delimitou sua exposição na tentativa de responder a duas questões: o que é cultura geral? De que modo esta contribui para a formação individual e social? O conceito de cultura, circunscrito nestas indagações, foi pensado com o apoio do ensaio de T. S. Eliot, de 1948, intitulado Notes towards the definition of culture. Ao sintetizálo, Nunes seguiu três direções: a) a acepção individual; b) a social; c) a histórica.

No primeiro sentido, a cultura corresponde ao "equipamento mental do indivíduo (...), posse intelectual, moral ou religiosa, que se alia à personalidade do sujeito”. (p.7) A definição também abrange a etimologia - colere/cultivar - da palavra, o “cultivo” do indivíduo, seu modo de ser. Esses aspectos são denominados “eixo subjetivo”.

A social e a histórica equivalem ao eixo objetivo. Na “acepção social”, a cultura significa a herança transmitida de geração a geração, partilhada pelos indivíduos em conformidade com o dinamismo do grupo ou das classes sociais a que se vinculam.

A terceira concepção, a “histórica”, representa a expressão intelectual, artística e moral de uma determinada civilização ou de um povo no decorrer de sua história. Ligada ao processo histórico, a cultura é dependente de uma transmissão ou acumulação de valores, formas de pensamento, técnicas e normas entre unidades históricas de mesma filiação.

Os três enfoques - individual, social e histórico - compõem uma só idéia, que é ampliada pelo conceito antropológico de cultura, já que a Antropologia faz desta "um fenômeno co-extensivo à sociedade humana, qualquer que seja o grau ou estágio de adiantamento material desta”. (p.9)

A Antropologia confirma que, pela forma de pensamento e linguagem, o homem é igual em toda a parte e diferente pelo modo como "estatui sistemas normativos reguladores de suas relações com os outros e com a Natureza”. (p.22) Civilizados e selvagens tornam-se comuns, porquanto criam mitos, artes e conhecimento. 
Um sintoma da crise da cultura advém da cisão no projeto da vida intelectual. Crise que pode ser resumida pela dessacralização de conceitos e que leva à sociedade massificada, à individualização, às influências das mass media.

A perspectiva de cultura geral expressa na origem de um humanismo alargado, na aproximação do espírito não-utilitarista dos primitivos às tendências tradicionais da civilização do Ocidente, contribui para afastar três falácias: de que a Arte não é pensamento; de que a Ciência é todo conhecimento; de que o conhecimento é eticamente neutro.

No novo humanismo, o homem deixa de ser escravo da Natureza para ser o seu próprio “vigilante guardião”.

A cultura passa a significar, assim, na convergência das artes, ciências, letras, e técnicas - características da cultura geral -, “cultivar, habitar, tomar conta, criar e preservar”. (p.24)

\section{I.3. Outras produções e a recepção à obra de Benedito Nunes}

Em entrevista concedida um pouco antes de falecer ao jornal Folha de S. Paulo, Caderno Mais! (14 de setembro de 2003, p.8-11), Haroldo de Campos (1929-2004) comentou sobre os críticos contemporâneos a ele e os mais recentes. Assim se referiu a Benedito Nunes:

(...) O Benedito Nunes e o Gerd Bornheim [morto em 2002] são dois casos que têm certos pontos de contato, de filósofos que fazem crítica e a fazem muito bem. Com muitas armas de conhecimento e sensibilidade. (...) Benedito Nunes, que também, em certos aspectos, é um...Heideggeriano. Benedito já se dedicou mais a outros aspectos literários. À Clarice Lispector, por exemplo, da qual, parece, é um dos mais argutos estudiosos. Ao João Cabral, ao Guimarães Rosa... Enfim, é uma pessoa que tem se dedicado, ao lado de sua formação de filósofo, ao estudo literário, o que é raro no ambiente brasileiro, em que, sobretudo, nas universidades - sobretudo na USP, graças a um certo tipo de inclinação que surgiu na evolução dos seus participantes do departamento -, a literatura sempre esteve à margem, não é? Enquanto, por exemplo, na filosofia francesa, Sartre desde logo sempre se ocupou da literatura e da literatura de vanguarda. Não esquecer, por exemplo, o Sartre escrevendo sobre Faulkner, o Derrida escrevendo sobre Francis Ponge, o Foucault escrevendo sobre o Roussel, um surrealista extremamente marginal que ele interpreta de uma forma extremamente sofisticada, de maneira muito fina, não é? Um homem que faz um livro a partir de anagramas. Enquanto aqui nossos filósofos eram especializados em determinadas angulações e raramente passava...(p.11)

Alguns anos antes, em 1981, Haroldo de Campos e Benedito Nunes achavam-se em Austin, como professores visitantes em um mesmo programa de Literatura Brasileira na 
Universidade do Texas. Nunes, mais tarde, narrou este fato em um texto intitulado "Encontro em Austin” (1991)

Em tal encontro, Nunes fez para Haroldo de Campos a leitura do livro, então em andamento, Passagem para o poético (Filosofia e Poesia em Heidegger), especialmente os capítulos referentes à concepção heideggeriana da linguagem e da poesia, em “Aus einem Gesprach von der Sprache” (“De uma conversação da linguagem”), cujo assunto já era conhecido do poeta e ensaísta paulistano.

\section{I.3.1. Passagem para o poético}

É importante ressaltar que, com Passagem para o poético (1986), Benedito Nunes conquistou o Prêmio Jabuti em 1987, ofertado pela Câmara Brasileira do Livro. Neste ensaio, o pensamento de Heidegger foi revisto e interpretado de modo singular em três momentos: “A caminho de Ser e Tempo", em que comenta o contexto biográfico-histórico-político do filósofo alemão, o problema e a questão do ser, o confronto com a Fenomenologia de Husserl e a acepção de Dasein como “ente que compreende o ser, (...) na sua existência, com que está concernido enquanto possibilidade sua, de ser ou de não ser ele próprio, e a partir da qual se compreende.” (1992 [2 ed.], p.68)

Em “Do ser ao tempo”, apresentou um estudo sobre a analítica do Dasein e os conceitos de Angústia, Liberdade, Temporalidade e Historicidade, aspectos revisitados e discutidos por uma leitura imanente da obra de Heidegger.

Na última parte, “Do tempo ao ser”, mostrou o embate da concepção heideggeriana, na primeira fase, com as filosofias da existência, o Kantismo e o sistema de Hegel; e, na chamada segunda fase, com os pré-socráticos, a poesia de Hölderlin e a obra de Nietzsche.

O vínculo entre pensamento e linguagem, a “viragem” responsável pela passagem do filosófico para o poético, a "prática meditante”, como ligação do sentido do ser à obra de arte, são linhas interpretativas que Nunes desenvolveu para, no final, retomar o vocábulo Dasein:

Quase impronunciado depois da viragem, é esse conceito-chave, ao qual talvez conviesse chamar de idéia, na acepção hegeliana do termo, tal a multiplicidade de relações que ele enfaixa - conceito vazado pela imagem de luz, antes de receber o nome de clareira -, que permite rebater o pensar meditativo sobre a Ontologia fundamental e entender o primeiro Heidegger por intermédio do segundo. Antecipando-se na compreensão do ser inerente ao Dasein da qual partiu o primeiro, a diferença, a verdade do ser, que se essencializa na linguagem, onde se dá a juntura

61 Este mesmo artigo foi publicado em MOTTA, Leda Tenório (org.). Céu acima. São Paulo: Perspectiva/FAPESP, 2005, livro editado em homenagem a Haroldo de Campos. 
do ser e do tempo como Ereignis, ao qual chegou o segundo, já predispunha a Ontologia fundamental a tornar-se um pensar poético (dichtend Denken), capaz de escutar o apelo utópico que do canto se desprende quando, na poesia, “é alto e régio o pensamento...”(1992 [2 ed.], p.293)

Da conversa com Haroldo de Campos sobre este livro, Nunes imaginou que o seu interlocutor pudesse continuar o diálogo iniciado com algum ensaio a respeito. Não obstante, Haroldo de Campos concretizou a discussão com o poema "Aisthesis, Kharis: Iki - Koan (glosa heideggeriana para Benedito Nunes)", de "Austinéia desvairada”, inserido em A educação dos cinco sentidos (1985).

\title{
I.3.2. Encontro em Austin
}

É a reflexão sobre esse "poema-comentário”, o cerne do texto "Encontro em Austin” (1991). Ei-lo:

\author{
"se heidegger tivesse olhado \\ para o ideograma \\ enquanto escutava o discípulo \\ japonês \\ (como pound olhou para ming ( ) sollua \\ com o olho cubista de gaudier-brzeska \\ depois de dar ouvido a fenollosa) \\ teria visto a cerejeira cereja koto ba ( ) \\ das ding dingt \\ florchameja \\ no espaço indecidível \\ da palavra \\ i k i” (p.150-1)
}

Para o crítico paraense, este texto representa a complexa problemática da linguagem, a incapacidade do filósofo em entender o significado da palavra iki, por não ter olhado para o 
ideograma no momento em que o discípulo palestrava acerca de sua acepção. Não olhou, porque o ouvir, o escutar, predominou sobre o ver como postura assumida relativamente ao dizer da linguagem.

Toda a filosofia de Heidegger, na sua etapa final uma recusa à filosofia em nome de uma hermenêutica da linguagem, enquanto interpretação do ser como único objeto do pensamento, baseou-se efetivamente num escutar, numa auscultação da palavra escrita, dos textos fundamentais de poetas e filósofos. (p.151)

O início de “Aus einem Gesprach von der Sprache - Zwischen einem Japaner und einem Fragenden” (“De uma conversação da fala - entre um Japonês e um Inquiridor”), alude ao diálogo que Heidegger manteve com o professor Tezuka, da Universidade Imperial de Tóquio, na década de 50, quando este o visitou. Um dos temas debatidos foi a expansão da técnica, que poderia descaracterizar a cultura do Extremo-Oriente, e a procura, por TezuKa, de aplicar a estética, já repensada fenomenologicamente, ao estudo da arte de seu país.

Na visão de Nunes, ambos poderiam entender que o significado de iki, "graça”, a kharis grega, para o japonês a “verdade da arte, é independente da estética”, e koto ba pétalas de flores brotadas da graça -, é, para o filósofo alemão, “a verdade da mesma linguagem, independentemente da lingüística, e incompatível com o idioma da metafísica que nos deu 'Sprache, glosa, língua e linguagem'”. (p.152)

Tal verdade, na raiz do poético, é o que a "linguagem diz mostrando ou o que ela mostra dizendo”, síntese hermenêutica da poesia do pensamento: só se mostra no dizer essencial para quem sabe “ouvi-lo quando ausculta a palavra”. (p.152)

No poema de Haroldo de Campos, há certa crítica a essa poesia do pensamento conforme formulada, pois, para ele, a "poesia do pensamento" apóia-se na metáfora, no uso de vocábulos gráficos, nos compassos de versos rítmico-semânticos, entre o som e o sentido, entre o semiótico e o semântico, na busca pelo “pré-categorial”, pelo “pré-reflexivo”, pela corporeidade e espacialidade do verbo.

Já para Heidegger, a escuta da palavra não a envolve na qualidade de signo. Há uma recusa à dualidade do significado e do significante, como "sombra metafísica do ente”, o que coloca em dúvida o metafórico ${ }^{62}$.

Quando ele [Heidegger] diz que 'o metafórico só existe no interior da metafísica', está concedendo demais à metafísica - esquecido de tudo o que o pensamento dos pré-socráticos deve à metáfora - e concedendo pouco à metáfora, como se

\footnotetext{
${ }^{62}$ Voltarei a esse assunto no terceiro capítulo.
} 
esquecesse que ele é o ato próprio da linguagem, a sua energia, para dizê-lo com Humboldt, ou o princípio do seu jogo, para dizê-lo com Wittgenstein. (p.152)

A aporia da prática meditante do filósofo acontece, pois, ao fazer falar a linguagem: ao eliminar a constituição simbólica da linguagem, ele elimina, também, a metalinguagem.

Heidegger não admitiria a reflexão assentada no “jogo da linguagem”. Jogo este que Haroldo de Campos faz ao aproximar poesia e pensamento, ou "poesia e filosofia”, se voltarmos ao título - “Aisthesis, Kharis: iki”: “(...) a ironia do comentário se prolonga na ironia da História: as duas matrizes gregas, a profana aisthesis e a kharis sacral, são postas em correspondência com iki, que as sintetiza”. (p.153)

No autor e ensaísta paulistano, a poesia do pensamento completa-se pelo pensamento da poesia, analisado histórica e criticamente.

Assim como Haroldo de Campos, outros poetas mantiveram diálogo com Nunes e o homenagearam em diferentes ocasiões, tais como Max Martins e Age de Carvalho. Um dos tributos mais relevantes que recebeu foi quando, em 1996, tornou-se Professor Emérito da Universidade Federal do Pará; o reitor, na ocasião, era o professor Marcos Ximenes Ponte.

Dois anos depois, houve uma festa da entrega do título, na sessão da Assembléia Universitária, em 30 de novembro de 1998, solicitada pelo então reitor Cristóvam Wanderlei Picanço Diniz. Na ocasião, a série de reverências à sua trajetória pessoal e profissional foi finalizada com um CD-ROM comemorativo - produzido no Laboratório “Graça Brüseke”, do Sistema de Informação da Amazônia Brasileira (INFORMAM) -, site na internet, executado por Ana Cláudia Gomes do INFORMAM ${ }^{63}$, e um livro denominado Benedictus, editado pela jornalista Ana Diniz. As séries de depoimentos ali assentados comentam da importância não só do acadêmico, mas da pessoa Benedito Nunes.

\section{I.3.3. Universidade e Regionalismo}

No ano seguinte, em abril de 1999, chamado para a aula inaugural do semestre, palestrou sobre o tema “Universidade e Regionalismo". Neste texto, foram registradas reflexões sobre a fase pré-universitária dos estudos da região Amazônica e a identidade da Universidade Federal do Pará, resultado dessa localização.

\footnotetext{
${ }^{63}$ Desde 2006, Benedito Nunes também possui uma comunidade no Orkut, feita por seus admiradores.
} 
Foi exposta a importância de uma intelligentsia, formada por médicos, advogados, professores sem formação acadêmica especializada, mas cujo autodidatismo proporcionou a criação de uma cultura erudita, “sem a qual nossa Universidade não teria existido”. (1999b, p.12)

Em seguida, comentou histórico-cultural e criticamente a região como referencial científico, literário e o regionalismo visto como perspectiva orientadora da criação artística e do conhecimento da realidade. Destacaram-se José Veríssimo e Inglês de Sousa, escritores nortistas, que produziram a “imaginária atmosfera de ambiências locais”. (p.8)

Ainda nesta aula inaugural, ponderou sobre a crise das Universidades perante o aparato tecnológico e o que chamou de "compensações”: a prática da interdisciplinariedade e a publicação de revistas e livros. (p.15)

Ainda é relevante lembrar que, em 1998, recebeu o Prêmio Multicultural promovido pelo jornal O Estado de S. Paulo. Nas inúmeras entrevistas que concedeu no momento, comentou o livro lançado naquele ano - Crivo de papel -, resultado da união de ensaios de Filosofia e Literatura, coletânea nos moldes de No tempo do niilismo e outros ensaios (1993). Em 1999, ganhou também o Prêmio Ministério da Cultura/Funarte.

A respeito de Crivo de papel, destaca-se a resenha crítica feita por Jean-François Nordmann (1999). Nesta, o então professor visitante da Universidade Estadual do Rio de Janeiro, teceu considerações sobre este trabalho, em particular, e a crítica desempenhada por Nunes, em geral.

\section{I.3.4. No tempo do niilismo e outros ensaios e Crivo de papel}

Em Crivo de papel, os estudos dedicados à literatura de João Guimarães Rosa, de Paul Valéry e de Carlos Drummond de Andrade estão ao lado de uma preleção sobre a historiografia literária brasileira, de uma análise sobre a tradição teológica da Filosofia e de seu questionamento do niilismo contemporâneo; da relação da música com a literatura, da reflexão sobre a ética da leitura...

Tal amplitude de temas foi articulada em uma abordagem em confronto com outros pensamentos e com uma prática de leitura cuja escolha pelo ensaio, pela variedade e diversidade de registros, tons e "timbres de estilo", caracterizaram uma escritura de rara acuidade crítica. 
Para Jean-François Nordmann (1999, p.424), esta obra de Benedito Nunes -

tecelagem de escritas próprias e de reescritas de leituras - não tem uma mera superfície homogênea e lisa, mas apresenta voluminosidades, texturas e densidades múltiplas: trata-se, na verdade, de uma espécie de pele sensível e vivente, capaz de exercer multidirecionalmente sua função analítica e hermenêutica.

Cada texto mereceu, por parte de Nordmann, um exame cuidadoso, às vezes em comparação com o No tempo do niilismo e outros ensaios (1993). A dimensão poéticofilosófica, que desponta em cada investigação produzida por Nunes, foi ressaltada como uma interessante "sensibilidade”, pois permite uma “espécie de alegria” (p.426) no trabalho da escrita, na qual o pensamento se funde à linguagem.

Esta natural qualidade de seus textos tem sido comentada, igualmente, por outros autores interessados em pôr em relevo a postura analítica de Benedito Nunes. Postura esta marcada por um novo modo de pensar o poético, o filosófico; por um constante desdobramento de uma interpretação singular, resultado de uma experiência de leitura indissociável da experiência de vida. (Nunes, 1998, p.175)

Surgem, assim, trabalhos referentes a essas questões, como as dissertações de mestrado Alguns aspectos da crítica literária de Benedito Nunes (PUC/RS, 1976), de José Guilherme de Oliveira Castro, a respeito do O dorso do tigre (1969); A filosofia da arte para Benedito Nunes (PUC/RJ, 1978), de Maria Neuza Monteiro, acerca de Introdução à Filosofia da arte (1966); Filosofia e ficção: o ser em O drama da linguagem, de Benedito Nunes (UFSC/SC, 2003), de Nilo Carlos Pereira, sobre o princípio do ser na crítica de Nunes, especificamente no livro $O$ drama da linguagem (1989); Perspectivas e possibilidades de aproximação da filosofia e literatura no pensamento de Benedito Nunes (UNICAMP/Campinas, 2003) de Fátima Aparecida Chaguri Oliveira, da área de Educação, voltada na defesa da articulação dos estudos da linguagem literária e filosófica na disciplina de Literatura, com exemplos da crítica de Nunes a respeito dos textos de Guimarães Rosa; Diálogos filosóficos com Benedito Nunes (UFAM/AM), de Andréa Costa de Andrade, sobre os livros Introdução à filosofia da arte (1966) e Crivo de papel (1998).

Ainda com relação às resenhas críticas, gostaria de enfatizar, especialmente, uma reflexão que reitera o horizonte crítico de Nunes: “O trabalho da hermenêutica - Benedito Nunes examina laços entre poesia e filosofia” (2000), de Franklin Leopoldo e Silva.

O interessante desse estudo, que nasceu a respeito do livro Hermenêutica e Poesia - o pensamento poético (1999), foi deixar registrado, em breves observações, a tarefa 
hermenêutica que Nunes empreendeu ao fomentar um diálogo entre a poesia e a filosofia, “considerando a distância aberta na linguagem e a proximidade do ser que a habita”. (SILVA, 2000, p.6)

Para Silva, Benedito Nunes soube compreender os laços que separam e aproximam poesia e filosofia e, mais do que acompanhar o pensamento de Heidegger acerca dessa relação, soube construir um pensar “conjuntamente (...), tirar proveito daquilo que a interrogação irradia como possibilidade de um novo questionamento, que abala velhas respostas com a força da radicalidade de outras perguntas”. (2000, p.6)

\section{I.3.5. Hermenêutica e poesia}

Hermenêutica e poesia é a reunião de escritos organizados pela professora Maria José Campos, com base nas aulas ministradas por Nunes, de novembro a dezembro de 1994, na Faculdade de Filosofia e Ciências Humanas da Universidade Federal de Minas Gerais.

O principal enfoque destas exposições foi a “dialogação” heideggeriana com a poesia, “dialogação” esta já presente em outros momentos, como em "Hermenêutica e poesia”, texto de No tempo do niilismo e outros ensaios (1993) e "Poética do pensamento", originalmente uma conferência apresentada no Ciclo Arte/Pensamento (Funarte, Rio de Janeiro/São Paulo, maio/junho de 1994), depois publicada em Artepensamento (1994), com organização de Adauto Novaes, e em Crivo de papel (1998).

Nesse livro, a relação filosofia e poesia foi discutida como uma confrontação no campo do pensamento, para o qual buscou apoio em uma citação de Juan de Mairena, heterônimo de Antonio Machado: "Há homens, dizia meu mestre, que vão da poética à filosofia; outros que vão da filosofia à poética. O inevitável é ir de um ao outro, nisto como em tudo”. (MAIRENA apud NUNES, 1999, p.14)

Em seguida, observou esse paralelo na tradição clássica, em que houve um relacionamento unilateral e a filosofia passou a valorizar a poesia sob o interesse cognoscitivo. No século XVIII, assinalou a idéia de mímesis e, no Romantismo, a ligação desse movimento com o idealismo germânico na procura de uma síntese entre a filosofia e a poesia.

Ressaltou, porém, que a trama entre essa articulação só encontrará dialogação no Heidegger da "segunda fase”. Esse trato dialogal levaria a um pensamento poético, ou, a uma 
poesia-pensante. Voltou-se, então, ao comentário de Heidegger a um hino de Hölderlin (p.19) em “O que significa pensar?”, e propôs que só se passasse a discutir essa dialogação após recapitular a reflexão heideggeriana a partir de Ser e Tempo (1927). Nesta obra, dois motivos acenaram para esse diálogo: a primazia da interpretação sobre o conhecimento teórico e o desvio da noção clássica de verdade.

No capítulo dedicado a "filosofias da vida", enfocou as noções de compreensão e de vivência, em Dilthey, e, na Fenomenologia, de Husserl, procurou mostrar como desta derivou uma fenomenologia hermenêutica ou uma hermenêutica fenomenológica. Desenvolveu, então, como esta serviu de método à Analítica do Dasein e, por conseqüência, de suporte a uma Ontologia Fundamental.

Na Analítica, distinguiu as principais linhas da constituição do Dasein, como a noção de temporalidade, de que derivou a qualidade do próprio Dasein, isto é, do ser humano como temporal e da compreensão do ser, que se apóia na temporalidade. (p.66)

Ao focalizar a interpretação, entendeu-a unida pelo discurso, que é a "articulação significacional da compreensão” (p.75). A compreensão é produzida por meio do discurso, mas não limitada pela relação predicativa. Nessa primeira noção do interpretar, “a característica mais proeminente é a sua circularidade: não interpretamos sem haver antes compreendido. Há uma compreensão prévia que toda interpretação exige”. (p.76)

Da interpretação e do discurso partiu para discutir a noção de verdade como caráter derivado da proposição relativa à interpretação. Em Ser e Tempo, a verdade remete à abertura, “iluminação do Dasein em seu estado de ser-aí, de ser-no-mundo”. (p.84) Encontrase não na proposição, mas no Dasein. Trata-se da verdade como a-létheia, como sentido de não-ocultamento, de des-velamento.

Em seguida, mostrou, porém, que as afirmações “o Dasein é verdadeiro, ele está na verdade” (p.84) se contradizem. O Heidegger da "segunda fase” irá dizer, então, que a verdade não é do Dasein, mas do próprio Ser, concepção com que trabalha em A Origem da Obra de Arte.

“A Origem da Obra de Arte” (cap. VIII), na qual foi apresentada a meditação heideggeriana sobre o quadro de Van Gogh - representação das botas de um camponês -, constituiu, segundo Silva (2000), o núcleo central desse estudo, já que “o autor tece considerações compactas, mas elucidativas, acerca das implicações existenciais da relação entre a obra e o espectador”. (p.6) 
Na seqüência, o crítico paraense comentou sobre como a Hermenêutica, da "fase" que Heidegger denomina "viragem" (kebre), desembocou na destruição da história da Ontologia e na destruição da própria Estética.

Por sua vez, "O niilismo e o pensamento poético"- releitura de Nietzsche por meio de Heidegger $^{64}$-, foi reproduzido, depois, em um número especial da Revista PZZ - Arte, Política e Cultura (ano II, n 3, abril/maio de 2006), de Belém do Pará, em homenagem ao professor paraense.

Por fim, conclui que "a dialogação da filosofia com a poesia, ou do pensamento com a poesia, é uma confrontação, mas com a extensão que a poesia toma como poíesis, como habitar poético". (p.160) Diálogo lançado ao futuro, "sob o resguardo da serenidade...”.

Esse debate aberto por Nunes na construção de sua analítica, oscilante entre um "pensar poético" e um "poetar pensante" (SILVA, 2000, p.6), desdobrou-se em uma reflexão, intitulada "Filosofia e literatura", de Abrahão Costa Andrade, cujo exame foi apontar a contribuição do pensamento do professor do Norte no exercício da investigação teórico-crítica de hoje.

"Filosofia e literatura”, a princípio, foi objeto da conferência apresentada na Semana de Filosofia da Universidade Federal do Rio Grande do Norte, em outubro de 2002, publicada depois no livro Angústia da concisão - ensaios de filosofia e crítica literária (2003), do mesmo autor.

Na sua exposição, Abrahão Costa Andrade revisitou a experiência de leitura de Nunes no seu processo de harmonização entre os procedimentos literários e a indagação reflexiva, representada, por exemplo, na sua análise de Grande sertão: veredas (1956), de Guimarães Rosa.

Para Andrade (2003, p.171), "relacionando filosofia e literatura, nosso Autor, mais do que crítico literário, preconiza um modo de pensar todo próprio, o qual poderíamos chamar uma filosofia da Inquietação".

\footnotetext{
${ }^{64}$ Cf. também sobre esta questão o livro O Nietzsche de Heidegger (2000), de Benedito Nunes. Ernani Chaves, no prefácio, ressalta as qualidades dessa releitura: "[Benedito Nunes] Munido não só de seu profundo conhecimento de Heidegger, mas também de uma sólida questão de ordem filosófica, que abre o texto - 'Como se entrosam e se diferenciam as filosofias? ' - e que se complementa com uma outra, mais fundamental, creio, aos olhos do autor, que é a da 'identidade filosófica', assistimos a mais um momento de tentativa de elucidação do lugar e do papel de Nietzsche no pensamento de Heidegger. Questão crucial, porque repõe, mais uma vez, aquela que parece ser a mais fundamental de toda a filosofia após Hegel: a da possibilidade da sua superação". (p.11-2)
} 
Não menos inquietante é o conto "Reflexões sobre uma viagem sem fim” (1992), que Milton Hatoum dedicou a Benedito Nunes.

\title{
I.3.6. “Reflexões sobre uma viagem sem fim”
}

Na criação do escritor amazonense, o personagem Felix Delatour é um professor bretão, circunspecto, morador de um sobrado de Manaus, e que sofre de uma doença, o gigantismo, que o mantém em certo isolamento. No seu exílio forçado, ministra aulas de francês, mas “o que lhe interessava eram as viagens, as muitas viagens que fizera durante a vida”. (p.62)

Além do “isolamento”, são as viagens o ponto de aproximação de Felix Delatour e Benedito Nunes. Também para este, a “viagem (...), além de tornar o ser humano mais silencioso, depura o seu olhar. A voz do verdadeiro viajante ecoa no rio silencioso do tempo”. (p.63)

Entretanto, Nunes retorna sempre a Belém, porto de origem:

\begin{abstract}
não me sinto isolado em Belém do Pará simplesmente porque sou um homem que gosta do isolamento. No Pará tenho muitas relações, muitos amigos, é bom dizer. Mas conservo também, é verdade, a distância e a calma que, para mim, são condições fundamentais para o trabalho intelectual. Vivo sim em um certo isolamento que não deve ser confundido, no entanto, com insulamento. Não estou incomunicável e não é uma fuga. A distância geográfica, ao contrário, me proporciona um refúgio, para o qual posso sempre retornar em segurança. Mas não sou uma planta nativa, presa definitivamente à floresta. Talvez por isso eu entenda a região amazônica sem precisar do apoio dos localismos. Prefiro falar, por exemplo, em uma literatura "da Amazônia" e não em literatura "amazônica”, denominação que inclui uma perspectiva regionalista. Ao falar em literatura "da Amazônia”, estou me referindo apenas a uma origem, uma procedência e nada além disso. ${ }^{65}$
\end{abstract}

\section{I.3.7. Crônica de duas cidades: Belém e Manaus}

A Belém de Benedito Nunes e o universo da Manaus de Milton Hatoum são lugares/imagens que os autores compartilharam em Crônica de duas cidades: Belém e Manaus (2006), livro dividido em duas partes: “Pará, capital Belém” e “Amazonas, capital Manaus”. São memórias que se diferenciaram pelo traçado da recordação: histórica, calcada na lembrança e no testemunho artístico-cultural, em Benedito Nunes; e em tom de confissão, em um emaranhado entre a história da cidade e a narrativa pessoal de Milton Hatoum.

Assim iniciou o crítico paraense:

\footnotetext{
${ }^{65}$ Entrevista a José Castello, O Estado de S. Paulo, Caderno 2, 1983, www.secrel.com.br/jpoesia/castel06.html. (Acesso em $1^{\circ}$ de março de 2003).
} 
Tento, finalmente, pagar uma velha dívida minha com Belém, tema deste trabalho. O débito é também para uma geração daqueles que puderam vivê-la entre 1940 e 1960, muitos dos quais já se foram, quando ainda era uma cidade amável. Traço apenas, como num desenho à mão livre, o meu retrato de Belém, valendo-me das boas fontes hoje disponíveis. (2006, p.11)

Seguiu-se, depois, um relato que se estendeu em arco do século XVII, com Padre Vieira, Landi e La Condamine, a Belém de hoje, que Fábio Castro ${ }^{66}$ chama de "cidade sebastiana, cidade que alimenta o desejo da volta dos tempos de Ouro, como um novo sebastianismo, que aguardasse o retorno de um Dom Sebastião morto no Alcacer-quibir da borracha, nas águas do Amazonas”. (NUNES, 2006, p.39)

$\mathrm{Na}$ fronteira entre o texto descritivo e o crítico, discorreu sobre as lutas de Independência, o ciclo da borracha e a mão-de-obra de extração - primeiro, a dos indígenas; depois, a dos nordestinos -, e de como houve na cidade, depois do influxo de estrangeiros, “tantos ricos no meio de tanta pobreza”. (p.21)

A face artístico-cultural da antiga Belém foi delineada por meio da evocação da música - da modinha ao clássico -, das óperas encenadas no Theatro da Paz, ou da commedia dell'arte, que representava o teatro popular. No Largo da Pólvora, o Montmartre paraense, encontravam-se os cafés e até um Moulin Rouge local. Era da belle-époque: "na expressão deliciosa de Haroldo de Campos, a mim pessoalmente endereçada certa vez, Belém do Pará tornava-se Belém de Paris”. (NUNES, 2006, p.32)

No recontar das tradições, dos costumes belenenses, Nunes citou a importância dos jornais diários, que, além de fomentar a discussão ideológica, estimularam a prática do jornalismo literário, revigorado em 1946, com o Suplemento da Folha do Norte, no qual iniciou seu ensaísmo crítico.

No capítulo "Fisiognomonia, imagens” elegeu e comentou quatro ícones urbanos de Belém: Largo de Nazaré, local da festa do Círio; Grande Hotel; Bosque Municipal; e a casa comercial Paris n`América. Os dois primeiros, só o conhecemos por meio da literatura e da fotografia. Como expressão e memória da cidade, esses ícones correm o risco de apagamento.

Conclui, portanto, o cronista: “a ser isso verdade, Belém estaria sob a ameaça de perder a sua própria identidade histórica e cultural”. (NUNES, 2006, p.41)

\footnotetext{
${ }^{66}$ Cf. CASTRO, Fabio Fonseca de. A cidade sebastiana: era da borracha, memória e melancolia numa capital da periferia da modernidade. Brasília, 1995. Dissertação (mestrado em Comunicação e Cultura) - Faculdade de Comunicação, Universidade de Brasília.
} 


\section{I.4. Fundamentos do método crítico}

Como consideração prévia, neste momento, interessa-me apenas salientar a natureza multifacetada da crítica literária ${ }^{67}$ e focalizar um método em particular, a hermenêutica - linha interpretativa na qual se move Benedito Nunes. Após um breve panorama sobre a tradição dessa corrente filosófica, comentar-se-á como o intérprete paraense, legitimado como hermeneuta, entende o ato crítico.

Antes, pode-se lembrar Antonio Candido (1981, p.32) ao nos mostrar que, por vezes, na função analítica, é possível aproximar o julgamento pessoal e o instrumental objetivo:

Toda crítica viva - isto é, que empenha a personalidade do crítico e intervém na sensibilidade do leitor - parte de uma impressão para chegar a um juízo, e a história não foge a esta contingência. Isto não significa, porém, impressionismo nem dogmatismo, pois entre as duas pontas se interpõe algo que constitui a seara própria do crítico, dando validade a seu esforço e seriedade ao seu propósito: o trabalho construtivo da pesquisa, informação, exegese.

Em um sentido amplo, a característica da crítica contemporânea ${ }^{68}$ revela-se como um novo gênero análogo à obra que analisa, isto é, um discurso crítico tão poético-ficcional quanto o texto que lhe serviu como base de exame ${ }^{69}$. Em resposta a uma literatura que se interroga enquanto linguagem, que possui em si a metalinguagem, a crítica torna-se, ela mesma, inventiva ${ }^{70}$.

Nesta perspectiva, Gerd Bornheim (2000, p.44) vislumbra o paradoxo em que essa vive: se a obra de arte já não se reduz à condição de um objeto, à mercê de um resultado analítico, o exercício crítico torna-se autônomo, “a concorrer de certo modo com a criatividade da própria arte”. Se a literatura põe em questão o seu sentido e a sua forma, a investigação já não pode operar apenas como função avaliativa, julgadora, mas ser também, leitura e escrita ${ }^{71}$.

\footnotetext{
${ }^{67}$ No capítulo 2, voltarei a essa questão.

${ }^{68} \mathrm{O}$ adjetivo contemporâneo, ou melhor, o conceito de contemporaneidade, tem suscitado impasses e polêmicas. No entanto, parece-me que João Alexandre Barbosa (1990, p.68) responde bem a esta questão ao propor discutir a evolução da crítica literária não em um sentido cronológico, como indicado por Alceu Amoroso Lima (1959), nem como a síntese realizada por Wilson Martins (2002), mas como marcada pela tensão entre análise formal e interpretação histórica.

${ }^{69}$ Esta tendência crítica encontra procedência em textos como os de Baudelaire, de Sartre, de Walter Benjamin, para citar os casos mais conhecidos. No caso deste último autor, Cf. o livro de Márcio Seligmann-Silva, Ler o livro do mundo - Walter Benjamin: Romantismo e crítica literária. São Paulo: Ed. Iluminuras, 1999.

${ }^{70}$ Cf. Leyla Perrone-Moisés, Texto, Crítica, Escritura. São Paulo: Martins Fontes, 2005. Originalmente Tese de Livre Docência em 1975; depois, pela primeira vez, publicada em 1978 pela Ática, a autora, neste livro, reflete sobre a questão da "crítica escritura”, que é conseqüência do entrelaçamento entre crítica e criação, e apresenta, como exemplos, Maurice Blanchot, Michel Butor e Roland Barthes.

${ }^{71}$ Cf. Roland Barthes, Essais critiques. Paris, Seuil, 1964 e Critique et vérité. Paris, Seuil, 1966. Há uma tradução, deste último livro, realizada por Leyla Perrone-Moiséis e publicada pela Perspectiva em 2003.
} 
Por outro lado, é interessante lembrar que Afrânio Coutinho (1978, p.92) questiona esta posição, pois, para ele, a crítica é uma

atividade reflexiva, a matéria-prima sobre que atua é a literatura, o fenômeno literário, expresso pelos diversos gêneros. Por isso que ela incide sua mirada indagadora sobre os gêneros, deduziu-se abusivamente que ela é também gênero. Como se a ciência que estuda as flores com elas se confundisse. A crítica literária tem por meta o estudo da literatura, dos gêneros, mas não é um deles.

Ao propor uma autonomia ao ato crítico, defende um método científico, de rigor reflexivo e intelectual na produção crítica.

Já Luiz Costa Lima (1980, p.113-114) indica uma ênfase na relação obra/leitor como estímulo para um imergir na historicidade do objeto literário, pois pleteia a "não-transparência entre experiência estética e juízo sobre o poético”. Isto é, visa ao desenvolvimento de uma atividade crítica capaz de mostrar a lógica de um objeto experimentado como estético, sem recorrer a um discurso de cunho científico ou ficcional:

A única maneira, em síntese, que encontro de justificar a função do crítico consiste
em convertê-la em função crítica, qualquer que seja o meio, universitário ou
jornalístico, onde se exerça. E isso contra os irracionalismos, seja o dos cientistas
(...) seja o dos humanistas, que parecem pensar que, mais do que idéia, o homem é
emoção. Contra eles, porque ambos terminam por justificar os regimes "de
segurança" e as ditaduras "benfeitoras".

De qualquer forma, os posicionamentos divergentes sobre a crítica, aqui apenas esboçados, apontam para as diferentes abordagens que ela suscita. Benedito Nunes escreveu, especialmente, sobre o período dos anos 50, tanto no texto "Ocaso da literatura ou falência da crítica?” (1999a) quanto em “Crítica literária no Brasil, ontem e hoje” (2000), e citou, como exemplo, o Segundo Congresso Brasileiro de Crítica e História Literária, em 1961, realizado pela Faculdade de Filosofia e Letras de Assis, palco de exposições das diferentes correntes que vigoravam entre nós.

\section{Como lembrou o professor paraense, a década de 50 é um}

novo momento de tensão entre a leitura crítica (...) enriquecida com a atividade de poetas-críticos - Mário Faustino, Décio Pignatari, Augusto de Campos, Haroldo de Campos, Ferreira Gullar e Mário Chamie - e a escrita dos escritores, abalada e fecundada com a publicação de Grande sertão: veredas (1956), de Guimarães Rosa, Duas águas (1956), de João Cabral de Melo Neto, e Laços de família (1960), de Clarice Lispector. (2000, p.61)

Da mesma forma, João Alexandre Barbosa (1990, p.69), no texto "Forma e história na crítica brasileira de 1870-1950”, situou este período como de ruptura, localizado, segundo ele, 
criava a necessidade de uma tal ruptura. Neste sentido, há extrema coerência naquilo que se produz e publica no Brasil nos anos cinqüenta; de um lado, por exemplo, estão as obras de João Guimarães Rosa e João Cabral de Melo Neto que passam a exigir da crítica, tanto na prosa da ficção quanto na poesia (e é do mesmo ano, 1956, o aparecimento de Grande sertão: veredas e Duas águas) mecanismos de apreensão mais refinados analiticamente para que a interpretação possa ser mais do que tautológica; e, de outro, está a defesa e ilustração de uma crítica sob a influência quer do close reading - técnica de esmiuçamento textual fornecida pelo New Criticism anglo-americano - quer, da estilística, seja a de origem germânica, em que sobressaem os ensaios de Leo Spitzer, Vossler ou Auerbach, seja a espanhola de Dámaso Alonso, Amado Alonso ou Carlos Bousoño.

Sem dúvida, esta década fundamentou a fase áurea da nossa crítica, veiculada, principalmente, pelo jornal, meio de que se serviu o exercício reflexivo desde as primeiras manifestações nos oitocentos ${ }^{72}$.

A crítica jornalística, na qual, como vimos, Nunes se iniciou, permite revisitar as variadas linhas de recepção que marcaram e, ainda hoje, marcam, a leitura dos textos literários. São tendências modelares de uma tradição analítica que, grosso modo, podem ser divididas em: a) ensaios, cuja relação com o literário é mais cientificista, preso a normas; b) outras que operam com uma visão mais criativa, ao privilegiar um olhar mais acurado para a natureza do poético e na busca de uma linguagem investigativa própria; e c) críticas que tentam alcançar um discurso único, nem cientificista nem ficcionista.

É nesse sentido que caminham obras pontuais sobre o ofício crítico, caracterizadas por retratarem diferentes olhares literários ${ }^{73}$. Da mesma forma, pode-se falar em métodos de interpretação que implicam, como afirma João Alexandre Barbosa (1980, p.20), “rigor na disposição do aprendizado crítico inserto em sua análise, não surgindo a todo o momento, como os andaimes não surgem para sempre nos edifícios terminados”. Métodos como "filtros fotográficos” (SEGRE, 1974, p.17) cuja função pode ser a de acentuar ou a de atenuar o objeto fotografado.

Com relação a esse tema, aliás, Haroldo de Campos, em texto sobre Luiz Costa Lima $^{74}$, observou que a importância de se compreender o que seja a crítica, por parte do leitor,

\footnotetext{
${ }^{72}$ Cf. o livro de Sérgio Micelli, Poder, sexo e letras na República Velha. São Paulo: Perspectiva, 1977, que aborda o papel da imprensa no século XIX, e História da imprensa no Brasil, de Nelson Werneck Sodré. Rio de Janeiro: Graal, 1978.

${ }^{73}$ Podem-se citar, como exemplos, livros como o de Salete de Almeida Cara - A recepção crítica: o momento parnasiano-simbolista no Brasil. São Paulo: Ática, 1983 -; o de Flora Süssekind - Papéis colados. Rio de Janeiro: Ed. UFRJ, 2002 -; e o de João Luiz Lafetá - 1930: a crítica e o modernismo. São Paulo: Ed. 34, 2000 -, entre outros.

${ }^{74}$ CAMPOS, Haroldo. “O lugar de Luiz Costa Lima”. In: LIMA, Luiz Costa. Vida e mimesis. São Paulo: Ed.34, p.9-13.
} 
e deste conseguir discernir sobre a escolha teórica do autor e do uso de seus métodos, torna o ato de ler mais favorável, “uma vez que a eleição do método (da meta-linguagem) não é inocente, mas, ao invés, afeta o recorte e a interpretação das produções literárias que constituem a linguagem-objeto submetida ao crivo do analista”75.

Para Benedito Nunes (2000, p.62), seja qual for a atividade judicativa, a maneira do fazer crítico se move sempre filosoficamente: "não há crítica sem perspectiva filosófica: a compreensão literária, ato do sujeito, implica uma forma singular de conhecimento, logicamente escudado e constituído pelo método próprio de que se utiliza”.

A tarefa hermenêutica a que se propõe tem como principal atividade uma dinâmica de interpretação cujo deslocamento se apresenta na confluência entre aquilo que a obra revela e a nossa apreensão do seu sentido. Neste caminho, o método hermenêutico fundamenta-se no transitar dessa dualidade, possível apenas na “abertura” da obra à profundidade interpretativa, isto é, “abertura” do sujeito manifestada pela inquietude da arte, razão do movimento e do encontro hermenêutico.

\section{I.4.1. Breves interfaces do pensamento hermenêutico}

De um modo geral, a Hermenêutica ${ }^{76}$ (ou arte da interpretação) possui um largo rastro histórico, cujo desenvolvimento suscitou diferentes vertentes e posições face ao problema da interpretação.

Suas fontes estendem-se da época clássica, quando se procurava entender a epopéia homérica, às concepções medievais, por meio de uma hermenêutica teológica preocupada com os sentidos dos textos sagrados.

Assim, tanto como função dos comentaristas de Homero quanto como dos escolásticos, a hermenêutica antiga assentava sua atividade na distinção entre o sentido literal (gramatical) e o figurado (alegórico) das palavras.

Embora desde a Antigüidade o exercício da interpretação seja notório, o vocábulo Hermenêutica aparece como título de obra somente em 1654 - Hermeneutica sacra sive

\footnotetext{
${ }^{75}$ Ibid, p. 9, grifos do autor. O conceito de metalinguagem aí exposto, porém, encerra ampla discussão. Cf. PORTELLA, Eduardo. Teoria da comunicação literária. Rio de Janeiro: Tempo Brasileiro, 1976, p.50-4.

${ }^{76}$ Vale lembrar que o verbo hermeneuein é dizer, explicar e traduzir. Cf. PALMER, Richard. Hermenêtica. Trad. Maria Luísa Ribeiro. Lisboa: Edições 70, 2006.
} 
methodus exponendarum sacrarum litterarum, de J. Dannhauser -, data marcante da diferença entre a hermenêutica teológico-filosófica e a jurídica ${ }^{77}$.

Com a Reforma, o método alegórico é condenado, pois se tenta um retorno às fontes dos textos sem uma alegorização religiosa. Não obstante, este embate não impediu que o desenvolvimento da hermenêutica continuasse ligado a um projeto da Religião, mesmo com a busca de uma consciência metodológica incumbida de apreender objetivamente a letra do texto.

Costa Lima (2002, p.66) destaca o caráter desse momento como o de uma hermenêutica de ordem mais lógico-filosófica, ainda que, até o século XVIII, esta disciplina se conservasse fragmentada, dependente da teologia e da filologia e realçada apenas por meio da gramática e da retórica antigas.

Com Friedrich D. E. Schleiermacher (1768-1834), no Romantismo, a hermenêutica alcança um destaque outro, porquanto este lhe imprime um tratamento mais sistematizado, preocupado em instituir uma metodologia científica da interpretação, ao dotá-la de uma forma mais geral por meio do conceito de compreensão ${ }^{78}$.

A Schleiermacher interessava como o conhecimento se instituía, quais as razões e o método do processo de interpretação. Sua hermenêutica, portanto, nasce desse esforço para promover a exegese e a filologia a uma “Kunstlehre, vale dizer, de uma 'tecnologia' que não se limita mais a uma simples coleção de operações desarticuladas”. (RICOEUR, 1990, p.20)

Restabelecida no domínio filosófico, base não só para a teologia, mas também para todas as ciências históricas, ele argumenta que a arte de compreender conecta-se com a arte de falar e com a de pensar. (SCHLEIERMACHER, 2003, p.15) A compreensão é, dessa forma, considerada como reconstituição histórica e divinatória dos elementos objetivos e subjetivos de um discurso falado ou escrito.

Sabe-se que Schleiermacher nunca escreveu um tratado propriamente dito sobre hermenêutica; o que temos são notas e comentários elaborados para seus cursos universitários. Nos apontamentos de 1809/10, o autor deixou registrados dois tipos de interpretação: a gramatical, objetiva; e a técnica, subjetiva. (SCHLEIERMACHER, 2003, p.69)

\footnotetext{
${ }^{77}$ Cf. LIMA, Luiz Costa. Hermenêutica e abordagem literária. In: Teoria da literatura em suas fontes. Rio de Janeiro: Civilização Brasileira, 2002, p.65.

${ }^{78}$ Neste sentido, Ricoeur aponta o quanto a hermenêutica tem como horizonte próximo o kantismo. Cf. RICOEUR, Paul. Du texte à l' action: essais d'herméneutique II. Paris: Seuil, 1986, p.78 e Interpretação e ideologias. Rio de Janeiro: Francisco Alves, 1990, p.20.
} 
A primeira refere-se aos componentes do discurso ao incidir sobre os caracteres lingüísticos do autor. É também chamada de negativa, porque aponta para os limites da interpretação, pois poderá haver erros ao se tentar buscar o sentido das palavras. Já na técnica, em que ocorre propriamente o projeto de uma hermenêutica, a interpretação dirige-se para a compreensão do uso individual e particularizado da língua pelo escritor. Na busca por abarcar a subjetividade, a linguagem fica à mercê da individualidade. É positiva exatamente por desejar atingir o ato de pensamento de quem produz o discurso.

A interpretação técnica é igualmente chamada de psicológica e envolve dois métodos: o divinatório e o comparativo. Naquele, procura-se apreender o individual diretamente; neste, busca-se primeiro compreender a obra como geral e depois descobrir sua singularidade por meio da atividade de comparação e contraste.

Em ambos vigora a idéia da circularidade: na gramatical, o processo circular ocorre entre parte e todo; na técnica, entre obra e autor: "gramatical. Impossível sem a técnica. Técnica. Impossível sem a gramatical. Pois, por onde conheço eu o homem senão apenas através de seu discurso, tanto mais que em referência a este discurso?” (SCHLEIERMACHER, 2003, p.93)

Como síntese, pode-se afirmar que o filósofo romântico, ao realçar o aspecto metodológico da hermenêutica, de maneira implícita ressaltou o surgimento das ciências humanas. Ao destacar o psicológico, pôs em relevo a aparição do indivíduo, já em evidência com o advento da ordem burguesa e, ao enfatizar sua autonomia, privilegiou o caráter contemplativo da especulação.

No âmbito da análise da literatura, duas correntes ligam-se à linha interpretativa de Schleiermacher: as chamadas práticas imanentistas, responsáveis por tentar apreender objetivamente o significado do texto, sem levar em conta o interesse da atuação e escolha do próprio analista; e a estilística, caracterizada por sublinhar o uso efetivo da linguagem. Ou melhor, verificar os modos de expressão específicos de um artista, de um gênero ou de uma época ${ }^{79}$.

As práticas imanentistas, por sua vez, vinculam-se a uma crítica fenomenológica ${ }^{80}$, derivada do método elaborado por Edmund Husserl (1859-1938). Husserl discutiu e

\footnotetext{
${ }^{79}$ Acerca da estilística Cf. WELLEK, René \& WARREN, Austin. Estilo e estilística. In: Teoria da literatura e metodologia dos estudos literários. Trad. Luis Carlos Borges. São Paulo: Martins Fontes, 2003, p.226-243.

${ }^{80}$ Sobre a crítica fenomenológica Cf. RAMOS, Maria Luiza. Fenomenologia da obra literária. Rio de Janeiro: Forense, 1969 e BORDINI, Maria da Glória. Fenomenologia e teoria literária. São Paulo: EDUSP, 1990.
} 
desenvolveu as noções de fenômeno de Kant (1724-1808) e Hegel (1770-1831). Para ele, não há fenômeno incognoscível e a consciência possui uma essência diferente da dos fenômenos, cujo princípio é a intencionalidade: a consciência existe dirigindo-se para algo. Fenômeno é eidos, essência, as significações ideais. Portanto, Fenomenologia ${ }^{81}$ é a descrição de um conjunto de fenômenos, ou essências, ou significações tais como se manifestam no tempo e no espaço, em oposição às leis abstratas e fixas desses fenômenos. Cabe a essa ciência restabelecer a filosofia ao seu início, por uma ação de redução (epoché), que dirige o pensamento ao campo das vivências intencionais como os primeiros dados absolutos. A importância recai no sentido, na rede de significações que envolvem os objetos percebidos.

Aplicados ao estudo da obra literária, os pressupostos da fenomenologia foram empregados por Roman Ingarden e pela chamada Escola de Genebra (décadas de 40 e 50), cujos representantes são: o belga Georges Poulet, os críticos suíços Jean Starobinski e Jean Rousset; o francês Jean Pierre Richard; o alemão Emil Staiger e o crítico americano J. Hillis Miller.

Já na estilística, podem-se citar, na Alemanha, Vossler e Leo Spitzer; na Itália, F. de Sanctis e Benedeto Croce; na Espanha, Amado e Dámaso Alonso; e, na França, Charles Bally, J. Marouzeau, M. Cressot, P. Guiraud e M. Riffaterre.

Leo Spitzer (1887-1960) ${ }^{82}$, por exemplo, cita Schleiermacher ao propor uma leitura circular cujo movimento é o ir e vir do todo às partes e das partes ao todo ${ }^{83}$ : só se pode apreender o detalhe em função do todo e qualquer compreensão do particular pressupõe a apreensão do conjunto.

Além de Schleiermacher, as concepções de Spitzer articulam-se com as de Wilhelm Dilthey (1833-1911), que amplia o sentido de uma hermenêutica universal, sem dispensar o psicológico, ao domínio do conhecimento histórico. Histórico, por sua vez, é entendido como referência às visões do mundo com base em um conceito de vivência (Erlebnis), fundamentado nas três funções anímicas - afetividade, inteligência e vontade -, que determinam a nossa relação com o mundo, "imprimindo direção ao conhecimento teórico e à atividade prática”. (NUNES, 1999, p.44)

\footnotetext{
81 Pode-se citar, entre a vasta bibliografia sobre o assunto, o livro: DARTIGUES, André. O que é a fenomenologia? Trad. Maria José J. G. de Almeida. São Paulo: Centauro, 2002.

${ }^{82}$ Cf. SPITZER, Leo. Lingüística e Historia Literaria. Madrid: Ed. Gredos, 1968, p.40.

83 Com relação à leitura circular realizada por Spitzer Cf. BOSI, Alfredo. Sobre alguns modos de ler poesia: memórias e reflexões. In: Leitura de poesia (org.). São Paulo: Ática, p.14-18.
} 
Ao lado do histórico, Dilthey, para contrapor o positivismo, tentou conceder às ciências do espírito uma metodologia e uma epistemologia tão significantes quanto às das ciências da natureza. Neste sentido, pôs em oposição a explicação da natureza e a compreensão da história ${ }^{84}$.

Para ele, a compreensão é intuída como um processo em que se busca conhecer a vida psíquica e as suas manifestações fixadas por escrito. Assim, o intérprete, ao procurar objetivamente a compreensão dos textos, “deverá vivenciar a intencionalidade autoral e, com ela, a sua posição em um mundo, o do autor, que em princípio é distinto do seu”. (COSTA LIMA, 2002, p.67 - grifo do autor)

Essa idéia de intencionalidade aí exposta é fruto da aproximação que Dilthey teve com Husserl $^{85}$, por ocasião em que este concebia o psiquismo pela qualidade de dirigir-se a um sentido capaz de ser identificado. O psiquismo em si mesmo não pode ser alcançado, porém pode-se perceber aquilo a que ele visa, o correspondente objetivo e idêntico no qual o psiquismo se supera. O conceito da intencionalidade e do traço idêntico do objeto intencional possibilitou a Dilthey reforçar a sua noção de estrutura psíquica pela de significação.

Gadamer (2002, p.345), no entanto, aponta que, diferente de Husserl, para quem o significado resultava de investigações lógicas, para Dilthey, o significado não é uma noção lógica, mas é compreendido como expressão da vida ${ }^{86}$.

Benedito Nunes (1999, p.50) lembra-nos, ainda, de que Dilthey realça a superioridade da poesia sobre todas as artes, pois somente esta "pela capacidade de abrir o conhecimento da realidade não imediata, sobre a base da experiência da vida alargada por uma consciência do sentido do que acontece, abriga uma visão-de-mundo”.

Na visão poética do mundo, este acontecer se traduz em símbolo que, na relação com a religião e com a filosofia, reflete as conexões vitais de uma época na própria obra, independente do gênero a qual pertence. Novalis, Hölderlin, Schiller e Goethe foram os escritores românticos sobre os quais o filósofo alemão se debruçou, já que considerava a poesia o “triunfo da hermenêutica”. (GADAMER, 2002, p.351)

\footnotetext{
${ }^{84}$ Ricoeur, em "A tarefa Hermenêutica”, vai apontar o quanto essa dissociação foi prejudicial para a própria concepção de hermenêutica. Cf. RICOEUR, Paul. Interpretação e ideologias. Rio de Janeiro: Francisco Alves, 1990, p.17.

${ }^{85}$ Cf. RICOEUR, Paul. Interpretação e ideologias. Rio de Janeiro: Francisco Alves, 1990, p.26.

${ }^{86}$ Gadamer, mais adiante, observa que, se Dilthey qualifica a vida como um fato básico da história, não estabelece diferenças precisas com o conceito hegeliano de espírito. Cf. GADAMER, Hans-G. Verdade e Método. $4^{\mathrm{a}}$ ed. Trad. Flávio Paulo Meurer. Rio de Janeiro: Vozes, 2002, p.348-9.
} 
Se a hermenêutica de Dilthey centra a compreensão na transferência a outrem, interessada não propriamente naquilo que o texto anuncia, mas naquele em que nele se expressa, em Martin Heidegger (1889-1976), o tema da compreensão desvincula-se do diálogo com o outro, porquanto os fundamentos do problema ontológico necessitam ser descobertos ao lado da relação do ser com o mundo.

Diferentemente de Schleiermacher e Dilthey, a linha heideggeriana, em Sein und Zeit (1927), põe em dúvida a legitimidade da interpretação autoral, o que abala não só o psicologismo, mas também o objetivismo desejado pelo historicismo. Os acontecimentos históricos, pois, já não ocorrem na consciência dos contemporâneos, já que o ato de compreender e de interpretar não são, necessariamente, de ordem intelectual, posto que se funde com o próprio cerne da existência, o Dasein.

O Dasein não é um sujeito para quem existe um objeto, mas um ser no ser; é um lugar onde a questão do ser se manifesta. A compreensão do ser é o que diferencia o homem como Dasein, ou seja, como aquele ente que existe para compreender o ser e, por isso, pode interpretar a si mesmo e ao mundo.

Heidegger questiona a hermenêutica entendida como epistemologia, a fim de procurar esclarecer as suas condições ontológicas. A teoria do conhecimento é, assim, “transformada por uma interrogação que a precede e que versa sobre o modo como um ser encontra o ser, antes mesmo de se opô-lo como um objeto que faça face a um sujeito”. (RICOEUR, 1990, p.30)

A ontologia, por sua vez, "só é possível como fenomenologia”. (HEIDEGGER, 2002, p.66) O sentido metodológico da descrição fenomenológica é a interpretação. Deste modo, a fenomenologia do Dasein é "hermenêutica no sentido originário da palavra em que se designa o ofício de interpretar”. (p.68) Há, assim, em Heidegger, o exercer de uma prática hermenêutica fenomenológica, ou, fenomenologia hermenêutica.

Fenomenologia e Hermenêutica, segundo Nunes (1999, p. 54), podem cruzar-se se a essência de um ente for “a compreensão do sentido desse mesmo ente”. Na fenomenologia reinterpretada, a intencionalidade já não é mais, como foi para Husserl, qualidade essencial da consciência, mas o trajeto para o ser compreendido, para o ser pré-descoberto, do qual a consciência é o ponto de abertura. Ao estabelecer como tema de investigação filosófica a vida fáctica, Heidegger assinala-á como hermenêutica fenomenológica da facticidade, isto é, do Dasein. 
Com efeito, em Sein und Zeit (1927), a questão sobre o sentido do ser como tema nuclear da obra prioriza a problemática da interpretação sobre o conhecimento teórico. Este resulta da interpretação como experiência incontornável do homem como ser-no-mundo.

Portanto, não há interpretação sem prévia compreensão do sentido daquilo que nos dispomos a entender:

\begin{abstract}
Na compreensão, a pre-sença projeta seu ser para possibilidades. Esse ser para possibilidades, constitutivo da compreensão, é um poder-ser que repercute sobre a pre-sença as possibilidades enquanto aberturas. O projetar da compreensão possui a possibilidade própria de se elaborar em formas. Chamamos de interpretação essa elaboração. Nela, a compreensão se apropria do que compreende. Na interpretação, a compreensão se torna ela mesma e não outra coisa. A interpretação se funda existencialmente na compreensão e não vice-versa. Interpretar não é tomar conhecimento de que se compreendeu, mas elaborar as possibilidades projetadas na compreensão. (HEIDEGGER, 2002, p.204 - grifo do autor)
\end{abstract}

Tal como Schleiermacher e Dilthey reconheceram, a hermenêutica pressupõe um movimento circular. Em Heidegger, envolve o princípio da contextualidade, isto é, a correlação no texto entre o sentido das partes e o sentido do todo; não podemos interpretar algo sem haver antes compreendido. Em outras palavras: ao interpretar, ligamos, por meio do discurso, o que compreendemos, e o que compreendemos, neste momento, compreendemo-lo no tempo, tanto de maneira prospectiva quanto retrospectiva, sob um passado que permanece no presente e no futuro que naquele se projeta. Pode-se dizer, assim, que o círculo hermenêutico é temporal, histórico e discursivo.

O discurso é definido, pois, como articulação do compreender, como o "fundamento ontológico-existencial da linguagem” (HEIDEGGER, 2002, p.219), concebido sempre em uma interpretação. A compreensão é produzida por meio do discurso, mas não limitada pela relação predicativa. O discurso articula a compreensibilidade e possibilita a interpretação, porque é para ele que se desloca a práxis da qual se origina o sentido. É, porquanto, o fenômeno “de que a linguagem é a instância ôntico-empírica”. (NUNES, 1992, p.173)

A linguagem é entendida como "pronunciamento do discurso". (HEIDEGGER, 2002, p.219) A fala e a linguagem se encontram implicadas no discurso, de que o ouvir e o silenciar são suas possibilidades. Por isso, “a primeira determinação do dizer não é o falar, mas o par escutar-calar-se. Ainda aqui, Heidegger toma a contrapartida da maneira ordinária e, mesmo, lingüística, de situar no primeiro plano a operação de falar (locução, interlocução)”. (RICOEUR, 1990, p.35) 
Não há interesse em produzir a palavra, mas em recebê-la, já que o ouvir é característico do discurso. A escuta, pois, constrói a relação primordial da palavra com a abertura ao mundo e ao outro.

A abertura, da qual a noção de compreensão não pode ser separada, é o des-velamento (alétheia) do ente que se efetiva no Dasein. Ela constitui, desse modo, a esfera do desvelamento, de onde a verdade se manifesta. O lugar da verdade, assim, não é a proposição, mas o Dasein, de cujo traço descobridor procede.

Não obstante, na chamada segunda fase, Heidegger irá afirmar que a verdade não é do Dasein, mas do próprio ser. É sob este conceito que escreverá, por exemplo, A origem da obra de arte $(1935)^{87}$.

Nesta conferência, em que aparece a idéia de que a obra de arte tem origem na verdade como alétheia, a atitude hermenêutica da compreensão do ser recai nas descrições do quadro As botas de Van Gogh e do templo grego de Posêidon, em Paestum. Juntamente com Hölderlin e a essência da poesia (1936), estes textos, representativos do momento da História do ser, estendem o debate da “destruição” da História da Ontologia em uma “destruição da Estética”, cujo desenrolar será comentado na segunda parte deste estudo.

Em tal fase, também, a reflexão hermenêutica heideggeriana recai na linguagem dos textos de poetas como Hölderlin, Rilke, Stephan George e Trakl, a fim de, nesta dialogação com a poesia, escutar neles “a fala de um saber que não é o da Filosofia”. (NUNES, 1993, p.81)

A linguagem tem aí o sentido de "limiar de toda experiência artística” (NUNES, 1992, p.260), entendida como aceno para o ser com que o pensamento se corresponde, por meio de palavras essenciais nos pensadores e dos temas principais nos poetas. O poético e o lingüístico se entrelaçam e busca-se a poiesis da linguagem e a linguagem da poesia.

A dominância da voz da Poesia, sem negar a da Filosofia, confere ao hermeneuta a tarefa de auscultá-la sem traduzi-la em conceitos, de ressaltar sua condição pré-categorial, pré-simbólica e pré-objetiva. Desse modo, o intérprete é convidado “ao esforço de parodiar o

\footnotetext{
${ }^{87}$ Neste mesmo período, Walter Benjamin, pertencente à chamada Hermenêutica crítica, também se volta para a arte como tema de reflexão no texto "A obra de arte na era de sua reprodutibilidade técnica" (1936). Lucchesi (2005, p.73-4) aponta que, ainda que diferentes quanto às perspectivas políticas, em ambos o problema da temporalidade surge no tocante às relações entre arte, tempo e verdade. Cf. LUCCHESI, Ivo. Walter Benjamin e as questões da arte sob o olhar da hipermodernidade. In: Revista Comum. Rio de Janeiro, vol.11, n²5, dezembro de 2005, p.57 a 91. A respeito da possível aproximação entre Martin Heidegger e Walter Benjamin CF. BENJAMIN, Andrew e OSBORNE, Peter (orgs.). A filosofia de Walter Benjamin: destruição e experiência. Trad. de Maria Luiza X. de A. Borges. Rio de Janeiro: Jorge Zahar Editor, 1997.
} 
texto, e de interpretar a poesia com a poesia. A hermenêutica da poesia seria sempre poética”. (NUNES, 1993, p.95)

A reflexão sobre a obra de arte, à luz de uma hermenêutica filosófica, tem destaque igualmente em Wahrheit und Methode (1960), de Hans-Georg Gadamer (1900-2004), porquanto a experiência da arte serve como ponto de partida para o estudo do fenômeno da compreensão.

Na esteira de Heidegger, de quem assimila o conceito de compreensão como o modo de ser da própria presença (Dasein), Gadamer assim define sua hermenêutica no prefácio à $2^{\mathrm{a}}$ edição:

O sentido de minhas investigações não é, em todo caso, o de dar uma teoria geral da
interpretação e uma doutrina diferencial de seus métodos (...), mas procurar o
comum de todas as maneiras de compreender e mostrar que a compreensão jamais é
um comportamento subjetivo frente a um "objeto" dado, mas frente à história
efeitual, e isto significa, pertence ao ser daquilo que é compreendido. (2002, p.18-9)

Para o filósofo de Heidelberg, a hermenêutica se enraíza na experiência geral do cotidiano, interessado que está em mostrar como o fenômeno da compreensão opõe-se a qualquer tentativa de ser representado como um método científico, pois o que se enfatiza é o momento de sua aplicação. Aplicação diz respeito ao modo de explicar como a compreensão acontece e não como aplicação de conceitos ou teorias a uma ocorrência prática.

Sua pesquisa, assim, caracteriza-se por ser mais do que um procedimento analítico ou uma crítica do método. É, antes, “uma investigação (Inquire, Untersuchen) acerca dos pressupostos e do exercício da interpretação em geral”. (NUNES, 2004, p.169-170)

Para isso, perfaz um caminho em que discute a noção metódico-historicista da experiência humana, cônscio da natureza finita e da temporalidade do existir. Procura, ainda, esclarecer o sentido e a verdade filosófica sem os impasses da ciência, o que traz uma autonomia da filosofia entendida como hermenêutica não-ideológica. Tal autonomia “conquista-se na interdependência e exige, por isso, um reconhecimento do caráter eminentemente questionante, dialógico ou preconceptual de toda a compreensão”. (SILVA, 1995, p.8) A universalidade do problema hermenêutico ${ }^{88}$, decorrente daí, remete a uma experiência que se institui como questão constante, sobre a qual o pensamento se volta, sem as amarras das articulações teóricas ou ideológicas cientificistas.

\footnotetext{
${ }^{88}$ Veremos, mais adiante, o contraponto de Jürgen Habermas à universalidade pretendida pela hermenêutica filosófica de Gadamer.
} 
Neste contexto, desenvolve não uma doutrina de métodos das ciências do espírito, mas a possibilidade de um consenso sobre o que são estas ciências, para além de sua autoconsciência metódica, e o que as unem ao conjunto da nossa experiência de mundo.

Ao buscar e indagar a experiência da verdade, à frente do domínio da metodologia científica, ele debate sobre os três modos de experiência: da filosofia, da arte, da história. São estes, e não a ciência, que constituem para o autor os temas da sua reflexão.

Com este fim, recorre ao conceito de efeitos da história ${ }^{89}$, a fim de legitimar que estes resistem à sua cientifização. Por efeitos da história, como atuante em todo compreender da tradição, entende-se a permanência do significado, dos valores de textos passados no presente.

Esta releitura do passado com base no seu efeito no presente, em uma "fusão de horizontes”, mostra que o compreender é sempre dependente da pré-compreensão, anterior ao indivíduo e co-presente com o seu tempo. O conceito de horizonte já havia sido usado filosoficamente desde Nietzsche e Husserl. Gadamer (2002, p.452) o retoma e o explica como o "âmbito de visão que abarca e encerra tudo o que é visível a partir de um determinado ponto". Este conceito relaciona-se com o da situação que se "caracteriza pelo fato de não nos encontrarmos diante dela e, portanto, não podemos ter um saber objetivo dela”. (p.451)

Para Gadamer, ter horizontes representa poder ver para além do que está próximo de nós e saber elaborar a situação hermenêutica de modo a obter o horizonte de indagação correto para as questões que se apresentam frente à tradição. Isto equivale a reelaborar nossas preconcepções e pressuposições, da mesma forma que fazemos quando predispomos a participar de um diálogo. Compreender o passado pode ser associado a compreender outra pessoa. Em uma "consciência historicamente efetuada”, se pôr no lugar de outra pessoa não significa desconsiderar a si próprio; assim como interpretar o passado só é possível em vista do próprio presente.

O horizonte do presente não se forma pois à margem do passado. Nem mesmo existe um horizonte do presente por si mesmo, assim como não existem horizontes históricos a serem ganhos. Antes, compreender é sempre o processo de fusão desses horizontes presumivelmente dados por si mesmos. Nós conhecemos a força dessa fusão sobretudo de tempos mais antigos e de sua relação para consigo mesmos e com suas origens. A fusão se dá constantemente na vigência da tradição, pois nela o velho e o novo crescem sempre juntos para uma validez vital, sem que um e outro cheguem a se destacar explicitamente por si mesmos. (GADAMER, 2002, p.457 grifo do autor)

\footnotetext{
89 Adotarei, para ser coerente com o autor estudado, a tradução de Wirkungsgeschichte por “efeito da história”, usada por Benedito Nunes em Filosofia Contemporânea (2004, p.169-173).
} 
Na primeira parte de Wahrheit und Methode, a obra de arte será lida como exemplo “muito qualificado da compreensão. A arte não é mero objeto da consciência histórica, no entanto, a sua compreensão co-implica sempre uma mediação histórica”. (GADAMER, 2002, p.264)

Sob este ângulo, a experiência da arte, juntamente com a da tradição histórica, abrange um conceito de conhecimento e de verdade que revela o fenômeno da hemenêutica em toda a sua pertinência.

Esclarecida, assim, a oposição que a obra de arte apresenta ao objetivismo científico, Gadamer (2002, p.263) afirma que a "estética deve subordinar-se à hermenêutica” (grifo do autor). Subordinação esta que confere à hemenêutica uma amplitude além da consciência estética ${ }^{90}$.

Ainda no espaço desta primeira seção, ressalta-se a comparação da obra de arte com o jogo. Em outras palavras: o jogo é o "próprio modo de ser da obra de arte”. (GADAMER, 2002, p.174)

No discorrer de seus argumentos, destaca-se a observação de que a maneira de ser do jogo está em sua própria representação. Ou seja, seu modo de ser é o seu próprio alcance. De igual forma, o modo de ser da obra de arte "está em sua apresentação efetiva, não havendo, pois, sentido distinguir-se, por exemplo, a partitura musical e sua apresentação em um concerto.” (COSTA LIMA, 2002, p.77)

Na sua idéia de representação artística e de jogo há tanto um reconhecimento quanto uma descoberta, cujo receptor é sempre exigido, mesmo quando ocasionalmente não esteja presente, pela própria natureza ontológica da obra de arte. (GADAMER, 2002, p.187)

Este ponto, em que o papel do receptor é refletido, impulsionou o estudo da chamada Estética da Recepção e do Efeito, representadas por Hans Robert Jauss (1921-1997) e Wolfgang Iser (1926-2007), respectivamente.

De como estas vertentes se apropriaram ou refutaram o pensamento de Gadamer, será comentado, de modo sucinto, mais à frente. Por ora, é preciso ilustrar a segunda parte de Wahrheit und Methode, considerada a mais relevante por alguns pensadores ${ }^{91}$.

\footnotetext{
${ }^{90}$ Sobre esta questão e a experiência hermenêutica, vale Cf. VATTIMO, Gianni. "Ermeneutica e nichilismo”. In: La fine della modernità. Italy: Garzanti Editore, 1999, p.121-137.

${ }^{91}$ Cf. COSTA LIMA, Luiz. Hermenêutica e abordagem literária. In: Teoria da literatura em suas fontes. Rio de Janeiro: Civilização Brasileira, 2002, p.81; e RICOEUR, Paul. Interpretação e ideologias. Rio de Janeiro: Francisco Alves, 1990, p.104.
} 
O eixo da reflexão, neste momento, recai para a teoria da consciência histórica, mas, antes, o filósofo alemão trava um longo percurso que vai do romantismo, com Schleiermacher e da epistemologia das ciências do espírito, com Dilthey, à transposição ontológica, com Heidegger.

É discutida, ainda, a filosofia hermenêutica por meio da idéia de preconceito (Vormeinung), da tradição e da autoridade.

\begin{abstract}
A compreensão somente alcança sua verdadeira possibilidade, quando as opiniões prévias, com as quais ela inicia, não são arbitrárias. Por isso faz sentido que o intérprete não se dirija aos textos diretamente, a partir da opinião prévia que lhe subjaz, mas que examine tais opiniões quanto à sua legitimação, isto é, quanto à sua origem e validez. (GADAMER, 2002, p.403)
\end{abstract}

Ou seja, a interpretação é parcial, historicamente marcada e, ao intérprete, é vetado conhecer o em si da obra. É necessário deixar que o texto fale:

\begin{abstract}
Quem quer compreender um texto, em princípio, [deve estar] disposto a deixar que ele diga alguma coisa por si. Por isso, uma consciência formada hermeneuticamente tem que se mostrar receptiva, desde o princípio, para a alteridade do texto. Mas essa receptividade não pressupõe nem "neutralidade" com relação à coisa nem tampouco auto-anulamento, mas inclui à apropriação das próprias opiniões prévias e preconceitos, apropriação que se destaca destes. (GADAMER, 2002, p.405)
\end{abstract}

Se, nesse desenvolvimento, está presente o pensamento heideggeriano, é com base também em Heidegger que Gadamer desenvolve a crítica à tradição iluminista. O Iluminismo concebe o preconceito como negativo, “como resultante da oposição em abstrato da razão, privilegiada, face à autoridade, elemento que deveria ser ultrapassado”. (COSTA LIMA, 2002, p.82)

Gadamer inverte tal raciocínio e torna legítima a autoridade e os preconceitos advindos dela, bem como, defende que a tradição se revela no comportamento históricohermenêutico.

Para ele, suprimir o preconceito é impossível, não só porque há uma instância crítica que, a priori, pode validá-lo, mas também porque, diante dele, é plausível construir uma relação positiva com o objeto da compreensão.

Desse modo, para ele, compreender é sempre entender de outra forma o objeto compreendido. O significado de um discurso se determina por meio das convenções e valores que formam o preconceito internalizado pelos “sujeitos históricos. Uma época distinta carrega consigo, portanto, uma forma nova de compreender os produtos doutra época.” (COSTA LIMA, 2002, p.84) 
Neste sentido, a alteridade presente no ato de compreender é resultado das diferenças históricas e não individuais. Com esta assertiva, Gadamer elimina a idéia de individualização, defendida na vertente psicológica de Schleiermacher-Dilthey. A distância temporal, assim, é condição necessária para que o objeto compreendido seja revisto e questionado sem o mesmo preconceito de seus contemporâneos.

Em toda compreensão, por conseguinte, há a presença do efeito da história. Um texto gera efeitos e conseqüências que o autor não percebe ou não pode perceber, mas que determinam aquela situação hermenêutica diante da qual o receptor interpreta a obra.

\begin{abstract}
A consciência histórica tem de se conscientizar de que, na suposta imediatez com que se orienta para a obra ou para a tradição, está sempre em jogo esse outro questionamento [a história efeitual], ainda que de uma maneira despercebida e, por conseqüência, incontrolada. Quando procuramos compreender um fenômeno histórico a partir da distância histórica que determina nossa situação hermenêutica como um todo, encontramo-nos sempre sob os efeitos dessa história efeitual. (GADAMER, 2002, 449)
\end{abstract}

Outro aspecto que pode ser destacado da hermenêutica filosófica de Gadamer é a lógica da pergunta e da resposta. Seu ponto de partida é a afirmativa de Collingwood, segundo o qual só se compreende um texto quando já se compreendeu a pergunta da qual ele foi a resposta: "um texto só é compreendido no seu sentido quando se alcançou o horizonte do perguntar, que como tal contém necessariamente também outras respostas possíveis.” (GADAMER, 2002, p.544)

Vale lembrar que os conceitos de pré-compreensão e da tradição, base para a consciência histórica, estão entrelaçados pela linguagem, "na verdade o pressuposto por excelência, no qual repousa a singular universalidade do processo hermenêutico”. (NUNES, 2004, p.170)

A linguagem, dessa maneira, é tema de ampla exposição na terceira parte de Wahrheit und Methode, analisada no aspecto da conversação, da poesia e da interpretação. Em tais casos, ressalta-se a sua estrutura especulativa, “que consiste não em ser cópia de algo que está dado de modo fixo, mas um vir-à-fala, onde se anuncia um todo de sentido”. Sentido que aponta para uma construção universal-ontológica: “o ser que pode ser compreendido é linguagem”. (GADAMER, 2002, p.686-7 - grifo do autor)

Na intenção primeira de um breve panorama sobre a hermenêutica, faz-se necessário comentar a influência de Gadamer na reflexão de Hans Robert Jauss e Wolfgang Iser, referidos anteriormente. 
A Estética da Recepção e a do Efeito ${ }^{92}$ surgem na Universidade de Konstanz, de onde, em 1967, Jauss publica sua aula inaugural denominada “A história da literatura como provocação à ciência da literatura” e, Iser, em 1970, a reflexão “A estrutura apelativa do texto".

A recepção e o efeito estético formam os preceitos nucleares da Estética da Recepção e se aproximam, porque ambas as metas partem do princípio de que a obra literária só existe quando motivada pelo leitor. No entanto, divergem quanto ao método: o histórico-sociológico se refere à primeira, e o teorético-textual, ao segundo.

Em outras palavras, a teoria da recepção está ancorada na recepção histórico-literária das obras; a do efeito, na "relação dialética entre texto, leitor e sua interação. (...) É chamado de efeito estético porque - apesar de ser motivado pelo texto - requer do leitor atividades imaginativas e perceptivas, a fim de obrigá-lo a diferenciar suas próprias atitudes”. (ISER, 1996, p.16)

A estética da recepção, desenvolvida por Jauss, tem como objetivo, assim, criar um novo tipo de história literária, centralizada na literatura interpretada pelos seus vários momentos de recepção histórica. Seu interesse reside na maneira como a obra é ou deveria ser recebida.

Já o efeito estético, defendido por Iser, tem por horizonte tanto a interação entre texto e contexto quanto entre texto e leitor. O texto é compreendido como em processo e, por conseguinte, a interpretação da literatura visa: à função, que os textos realizam em contextos; à comunicação, por meio da qual eles difundem experiências que, apesar de não-familiares, são, contudo, compreensíveis; e à assimilação, segundo a qual se comprovam a "perfiguração da recepção” do texto, bem como as competências do leitor por ela instigadas.

Para Iser, a concepção de leitor implícito destaca as estruturas de efeitos do texto, cujos atos de compreensão relacionam o receptor a ele. O leitor implícito "não tem uma existência real, pois ele materializa o conjunto das pre-orientações que um texto ficcional oferece como condição de recepção a seus leitores possíveis”. (ISER, 1996, p.73) Iser tem como empenho, portanto, perceber o efeito, o contato que se estabelece entre um texto

\footnotetext{
${ }^{92}$ Vale lembrar que estas vertentes influenciaram Ricoeur na composição de sua fenomenologia da leitura. Cf. Temps et récit. T.III. Paris: Seuil, 1985.
} 
literário, possuidor de um horizonte aberto, de vazios ${ }^{93}$, e o leitor, cuja função será a de encontrar pontos de indeterminação, para preenchê-los com seu próprio imaginário.

Diga-se de passagem, é mais notória a difusão das idéias de Gadamer em Jauss do que em Iser. Isto porque Jauss, ao elaborar sua hermenêutica literária, privilegia a investigação histórica e liga-se à tradição da hermenêutica como teoria da compreensão. Na sua pesquisa, aparecem explicitamente alguns conceitos gadamerianos, já sublinhados, como o de horizonte de expectativas, responsável pelo restabelecimento da obra com o público; a lógica da pergunta e da resposta, que possibilita o diálogo entre o texto e a sua época e entre o texto do passado e o leitor do presente, da qual procede a fusão de horizontes; e a consciência dos efeitos da história, em que as repercussões da obra do passado agem sobre o sujeito e determinam sua interpretação.

Segundo Jauss, a hermenêutica literária deve desenvolver duas tarefas: de um lado, “aclarar o processo atual em que se concretizam o efeito e o significado do texto para o leitor contemporâneo e, de outro, reconstruir o processo histórico pelo qual o texto é sempre recebido e interpretado diferentemente, por leitores de tempos diversos”. (JAUSS, 2001, p.46)

Sua hermenêutica, para tanto, privilegia três fases: a de compreensão do texto, derivada da percepção estética e integrada à experiência primeira de leitura; a de interpretação, quando se restabelece, no horizonte da experiência do leitor, o sentido do texto; e a da aplicação, ocorrida quando as interpretações prévias são elaboradas e medida a história de seus efeitos.

Apesar da relevância do pensamento de Gadamer no desenvolvimento metodológico da Estética da Recepção e do Efeito, tanto Jauss quanto Iser afastaram-se do seu ex-professor, dado o ontocentrismo e o especulativismo com que a hermenêutica filosófica se construiu. Tal ontocentrismo "leva o autor [de Wahrheit und Methode] à parodoxal caracterização atemporal do clássico, ao desdém pela pesquisa histórica concreta, ao abandono de qualquer preocupação metodológica e à hipertrofia idealística do papel da linguagem”. (COSTA LIMA, 2002, p.90)

\footnotetext{
93 A questão dos vazios no texto literário já havia sido examinada por R. Ingarden. W. Iser, no entanto, ao mesmo tempo em que reconhece a influência do pensador polonês nas suas reflexões, mostra que dele também se afastou para conceber a sua teoria. Cf. ISER, W. A interação do texto com o leitor. In: JAUSS, Hans Robert et al. A literatura e o leitor. Textos de Estética da Recepção. $2^{\mathrm{a}}$ ed. Seleção, tradução e introdução de Luiz Costa Lima. Rio de Janeiro: Paz e Terra, 2001, p.102-106.
} 
Da mesma forma, contra a hermenêutica das tradições defendida por Gadamer, Jürgen Habermas (1929-) propõe uma hermenêutica crítica. De maneira sumária, pode-se afirmar que este observa a não-pertinência da afirmação gadameriana da universalidade hermenêutica, por exemplo, na idealização da linguagem como legitimadora de um status quo, de um padrão comum. Habermas defende, neste caso, o instrumental psicanalítico como questionador da suposta normalidade da comunicação cotidiana.

As oposições, aliás, entre as linhas do pensamento de Gadamer e Habermas, são resumidamente apresentadas por Paul Ricoeur (1913-2005), em Interpretação e ideologias (1990, p.119-120). De um lado, há a defesa de uma noção de preconceito; tradição cultural; a não-compreensão como empecilho interno à compreensão; e a tarefa hermenêutica sobre uma ontologia fundada no “diálogo que somos nós”. De outro, o desenvolvimento do conceito de interesse, de bases marxistas, reinterpretado por Lukács e pela Escola de Frankfurt; os apelos às ciências sociais críticas, diretamente empregadas contra as reificações institucionais; a criação de uma teoria das ideologias; e o chamado ideal regulador de uma comunicação ilimitada e incoercível que nos direciona a partir do futuro.

No entanto, Ricoeur acredita em uma “zona de recobrimento”, uma síntese dialética entre as antinomias desses autores. Seu objetivo é superar a alternativa entre a consciência hermenêutica de Gadamer e a consciência crítica de Habermas, em uma conciliação criativa das tradições e da crítica das ideologias. Para isso, elabora uma reflexão cujo intuito é “integrar a criticada consciência falsa na hermenêutica e conferir à crítica das ideologias uma dimensão meta-hermenêutica”. (JAPIASSU In: RICOEUR, 1990, p.12)

O projeto hermenêutico de Ricoeur tem, pois, a intenção de propor uma nova configuração à problemática hermenêutica, entendida como a "teoria das operações da compreensão em sua relação com a interpretação dos textos. A idéia diretriz será, assim, a da efetuação do discurso como texto”. (RICOEUR, 1990, p.17)

A sua noção de texto, por exemplo, esclarece a aporia hermenêutica da divisão diltheydiana entre explicar e compreender, porquanto postula uma complementaridade dessas duas posições, uma articulação dialética. Esta vinculação entre explicar e compreender aponta como Ricoeur ultrapassou a oposição entre verdade e ciência ou método da hermenêutica de Gadamer e efetua a mediação mútua de filosofia e ciências sem prejudicar a autonomia dos campos respectivos. 
Por compreensão, Ricoeur (1986, p.37) entende "la capacité de reprendre en soi-même le travail de structuration du texte et par explication l'opération de second degré greffée sur cette compréhension”.

Neste sentido, define a interpretação por esta mesma dialética da compreensão e da explicação no patamar do "sentido" imanente ao texto. Ao deslocar o eixo da interpretação da subjetividade para o mundo, subordina a intenção do autor ao referente do texto.

A hermenêutica, assim, edifica-se na tarefa de reconstruir o sentido, que pertence à estruturação da obra, e restituir a referência, cuja caracterização permite a esta lançar-se fora de si mesma para gerar um mundo:

\begin{abstract}
O sentido de um texto não está por detrás do texto, mas à sua frente. Não é algo de oculto, mas algo de descoberto. O que importa compreender não é a situação inicial do discurso, mas o que aponta para um mundo possível, graças à referência não ostensiva do texto. A compreensão tem menos do que nunca a ver com o autor e a sua situação. Procura apreender as posições de mundo descortinadas pela referência do texto. Compreender um texto é seguir o seu movimento do sentido para a referência: do que ele diz para aquilo de que fala. (RICOEUR, 2000, p.99)
\end{abstract}

Texto, ou linguagem como discurso, apresenta uma independência que modifica e intensifica a natureza intersubjetiva do diálogo: a escrita absorve a significação dos atos de linguagem, o dito ou "noema” do dizer. A intenção do autor só pode ser esclarecida por meio da interpretação, mas um texto possui sua própria autonomia em relação a ele. Com a compreensão de um texto projeta-se um mundo, ou novos aspectos do nosso ser-no-mundo. A subjetividade do leitor é igualmente operação de leitura: “se comprendre, c'est se comprende devant le texte et recevoir de lui les conditions d'un soi autre que le moi qui vient à la lecture”. (RICOEUR, 1986, p.36 - grifo do autor)

A questão principal, dessa forma, não é perceber, sob o texto, a intenção subjetiva do seu autor, mas assinalar, diante dele, o mundo que ele descortina: “ce qui est à interpréter, dans un texte, c'est une proposition de monde, le projet d'un monde que je pourrais habiter et où je pourrais projeter mes possibles les plus propres”. (RICOEUR, 1986, p.58)

O texto literário, ao deixar pendente a referência de primeiro grau, característica do discurso corriqueiro, emancipa uma referência de segundo grau, em que o mundo é manifestado como um panorama de nossa vida e do nosso projeto. Esta nova referência, para além da vida cotidiana, alcança o seu pleno desenvolvimento apenas nas obras de ficção e de poesia e constitui, segundo o filósofo francês, o problema hermenêutico fundamental. 
A reflexão teórica de Ricoeur parte, é importante assinalar, de uma revisão da hermenêutica romântica de Schleiermacher e Dilthey, da renúncia da subjetividade e do idealismo da fenomenologia de Husserl, ao aprofundamento de uma hermenêutica fenomenológica, a exemplo do que Heidegger, em Sein und Zeit (1927), e Gadamer, em Wahrheit und Methode (1960), já haviam realizados.

Seus primeiros trabalhos, aliás, são dedicados à obra de Husserl, mas, reconhece ${ }^{94}$, seguiu uma evolução de método: de uma fenomenologia eidética, desenvolvida em Le Volontaire et L'Involuntaire (1950); da hermenêutica do símbolo, em La symbolique du mal (1960) e De L'interprétation. Essai des interprétations. Essai d'herméneutique (1969); a uma hermenêutica sobre a linguagem, a partir de La métaphore vive (1975) e Temps et Récit (1983).

O método adotado de aproximação entre a Fenomenologia e a Hermenêutica, para ele, obedece às duas teses: 1 . Fenomenologia e Hermenêutica só se relacionam se o idealismo da fenomenologia husserliana se submeter à sua crítica pela hermenêutica; e 2. Para além da simples oposição, “il y a, entre phénoménologie et herméneutique, une appartenance mutuelle...” (RICOEUR, 1986, p.44) A Hermenêutica estabelece-se sobre uma base fenomenológica e a Fenomenologia só alcança o seu projeto filosófico ao usar a interpretação da Hermenêutica.

Para Benedito Nunes (2004, p.201), este empreendimento teórico de Ricoeur é compatível "com a redução que a Fenomenologia hermenêutica sempre pratica, dos conceitos e categorias às formas elementares da experiência vivida, à trama do mundo-da-vida (Lebenswelt), solo comum da poesia e das construções científicas”.

Com as ciências humanas, Ricoeur estabelece uma relação interdisciplinar, haja vista seu diálogo crítico com o Estruturalismo, a Psicanálise de Freud, a Filosofia da Linguagem, a Semiótica e a Semântica, presentes nas suas obras.

Não obstante, o salto fenomenológico hermenêutico de Ricoeur (1986, p.8), segundo ele, a sua contribuição pessoal, é o tema da distanciação, instância crítica com que realiza todas as operações de pensamento que destacam a interpretação.

A distanciação, “le correctif dialectique de celui d' appartenance” ou “d' une relation de distance qui oscille entre l'éloignement et la proximité”, possibilita que a crítica das

\footnotetext{
94 Cf. "Phénoménologie et herméneutique: em venant de Husserl”. In: Du texte à l' action - essais d' hermenéutique II, p.43.
} 
ideologias possa ser "incorporée, comme un segment objectif et explicatif, dans le projet d' élargir et de restaurer la communication et la compréhension de soi”. (RICOEUR, 1986, p.57) Este procedimento de distanciação crítica sustenta a dialética da proximidade e da distância no interior da interpretação.

À distanciação, que liberta o texto da relação com o autor e o subtrai às dissimulações da realidade cotidiana, responde-se o ato do sujeito chamado apropriação, pelo qual este objeta ao sentido e à referência propostos pelo texto. “Approprier, c'est faire que ce qui était étranger devient propre". (RICOEUR, 1986, p.60) É a oferta de mundo exposta pelo texto que é apropriada, segundo a superação da subjetividade ou “desapropriação” de si mesmo. Ao apropriar-se do sentido e da referência do texto, o sujeito distancia-se criticamente das próprias convicções e remonta “aux 'variations imaginatives’ sur le réel que la littérature de fiction et de poésie, plus que toute autre forme de discours, engendre”. (p.60)

Na concepção de Ricoeur, o mundo do texto não é, portanto, o da linguagem corriqueira; ele promove uma distanciação do real consigo mesmo. Neste sentido, é por meio da distanciação que a ficção gera uma nova apreensão da realidade: pela ficção, pela poesia, ampliam-se inovadoras possibilidades de ser-no-mundo; ficção e poesia miram o ser, já não sob a feição do ser-dado, mas sob a feição do poder-ser.

Ao pontuar a colaboração de Ricoeur a uma teoria filosófica da interpretação, é necessário lembrar que as suas investigações sobre a teoria do texto ligada à da ação geram novas contribuições ao campo do pensamento histórico e social-político. Sua preocupação passa, igualmente, pela abordagem da reciprocidade entre narratividade e temporalidade. A característica temporal da experiência, como referente comum da história e da ficção, constitui-se, para ele, em um problema único, que envolve a ficção, a história e o tempo.

Na sua análise hermenêutica sobre a linguagem, o papel desempenhado pela metáfora também ganha uma nova releitura: já não interessa mais a forma da metáfora (como foi para a retórica), nem tampouco o seu sentido (como para a semântica), mas a sua referência. A metáfora incide, desta forma, no domínio de redescrever a realidade, "o que acarreta a necessidade de uma tomada de consciência quanto à pluralidade dos modos de discurso e quanto à especificidade do discurso filosófico”. (JAPIASSU In: RICOEUR, 1990, p.9)

Por ora, deixo implicitamente em suspenso mais alguns aspectos da sua teoria sobre o texto. No momento oportuno, as condições de leitura de uma obra, que a reflexão ricoeuriana promove, serão retomadas, a fim de se discutir a instância crítica da interpretação. 
Enfim, estabelecidos alguns conceitos da tradição hermenêutica, ainda que breves, gostaria de retomar o objetivo de tal esforço. Da hermenêutica romântica de Schleiermacher e Dilthey; da ontológica de Heidegger e da filosófica de Gadamer; da crítica de Habermas e da fenomenologia hermenêutica de Ricoeur, o que está em pauta é a contribuição da leitura hermenêutica à crítica literária.

Com efeito, os critérios selecionados para esta questão privilegiaram distinguir, de cada autor estudado, os aspectos que pudessem elucidar, além das diferenças perceptíveis entre eles, aqueles cuja característica lançasse luz à problemática da interpretação literária.

É certa que a pretensão não foi seguir rigorosamente cada noção ou linha argumentativa dos filósofos escolhidos. Não obstante, cada observação posta em relevo se notabilizou por destacar uma postura digna de acentuar como se efetua o tratamento da compreensão do texto.

A intenção, pois, foi edificar um arcabouço teórico para poder se discutir, com maior solidez, como Benedito Nunes se inscreve como intérprete hermenêutico. Não se trata, no entanto, de afirmar que o professor paraense segue esta ou aquela vertente. Trata-se, antes, de verificar que, “o que separa o intérprete do leitor é a tênue película da consciência crítica e histórica, que une, por sua vez, o intérprete ao chamado crítico literário”. (NUNES, 1986, p.80)

Tal consciência crítica e histórica é o que qualifica Nunes como crítico nas suas investigações sobre o objeto literário. Todavia, cumpre esclarecer quais as implicações desta atitude nas suas análises. Ou melhor: como se realiza a sua leitura hermenêutica?

\section{I.4.2. Hermenêutica e crítica literária: o intérprete Benedito Nunes}

O texto de Nunes - "O trabalho da interpretação e a figura do intérprete na literatura” (1986) - permite-nos apresentar sucintamente algumas de suas reflexões sobre a atividade do crítico.

Com o objetivo de comentar a exposição de Alfredo Bosi, denominada "A interpretação da obra literária” (1986), ocorrida na $2^{\text {a }}$ Bienal Nestlé de Literatura ${ }^{95}$, Nunes parte de uma questão primeira e essencial: por que interpretar? Esta pergunta, no entanto, nos diz ele, transporta-nos para um problema maior: a relação opaca entre significação e

\footnotetext{
${ }^{95}$ Cf. PROENÇA FILHO, Domício (org.). Literatura brasileira: ensaios - Criação, Interpretação e Leitura do Texto Literário. Vol.II. $2^{\mathrm{a}}$ Bienal Nestlé de Literatura Brasileira. São Paulo: Norte, 1986.
} 
linguagem; isto é, o contato indireto e arbitrário que, como sabemos, ocorre entre palavra e coisa.

A interpretação surge, assim, como resposta imprescindível “à contingência do caráter simbólico da linguagem”. (NUNES, 1986, p.74) Coextensiva a este preceito, a Hermenêutica, como exegese textual, move-se na busca de aclarar o possível sentido atado à escrita, já que, para dizer como Foucault (1975, p.5), suspeita-se que “a linguagem não diz exatamente o que diz”.

Conforme Benedito Nunes, para que haja uma boa análise literária é preciso que o intérprete se movimente dentro do círculo hermenêutico, com base em uma leitura prospectiva que o faça apreender retrospectivamente o processo formativo da obra.

Neste sentido, descreve a problemática que se desenha ao adotar este ângulo de análise: 1. o confronto do intérprete com o texto, desdobrado em três questões: técnica, histórica e estética e 2. a completude dessa prática, isto é, a verificação da correspondência significativa interna da obra à característica histórica da qual deriva e na qual se reintroduz como produto cultural.

A questão técnica refere-se ao procedimento hermenêutico da interpretação, o deslocamento da parte para o todo e do todo para a parte. Para que isto se efetue, no entanto, é preciso que o crítico já tenha uma pré-compreensão do texto. À medida que a interpretação se torna mais profunda, a concepção prévia, advinda da primeira leitura, altera-se. Isto porque, a “tendência da interpretação é aliviar as projeções do próprio intérprete para que ele se conforme àquilo que Gadamer chama de a ‘coisa' do texto - a 'coisa' que o texto pode dizer, em diferentes situações, para diferentes leitores-intérpretes”. (NUNES, 1986, p.96)

É no diálogo estabelecido entre o hermeneuta e o texto, no intercurso dialético tal qual a lógica da pergunta e da resposta gadameriana ${ }^{96}$, que o trabalho interpretativo delineia sua forma: o intérprete questiona o texto, mas é por ele também questionado.

Como expôs Foucault, em Nietzsche, Freud e Marx (1975, p.18), na hermenêutica moderna, fundada por estes autores ${ }^{97}$, o ato interpretativo, ao envolver o próprio intérprete,

\footnotetext{
${ }^{96}$ Cf. GADAMER, Hans-G. Verdade e Método. $4{ }^{\mathrm{a}}$ ed. Trad. Flávio Paulo Meurer. Rio de Janeiro: Vozes, 2002, p.544-556.

${ }_{97}$ Benedito Nunes, em Crivo de papel (1998, p.88), ao comentar este texto de Foucault, acrescenta o filósofo Heidegger ao lado de Nietzsche, Freud e Marx, já que em Sein und Zeit (1927) a questão da interpretação aparece como o problema maior do pensamento.
} 
tende a alongar-se ilimitadamente, à ausência de um fundamento último. Em razão disto, o intérprete, ao realizar esse ato, ao mesmo tempo em que interpreta o texto, se interpreta.

Na poesia de João Cabral de Melo Neto, por exemplo, Nunes nos lembra que as palavras “pedra”, “secura”, “deserto”, temáticas integrantes da poética cabralina, oferecem uma probabilidade de primeira leitura, já que o trabalho interpretativo tenta rastrear esses temas a fim de ajustar, em um embate dialógico, as imagens, as analogias, os enunciados lógicos à perspectiva do lirismo de Cabral. Contudo, a interrogação do texto só acontece se houver um vínculo deste com o hermeneuta capaz de determinar a interpelação. No poeta pernambucano, em particular, e em outros autores do modernismo, em geral, o crítico Nunes aponta esse liame em razão da nova construção do fazer literário impresso por eles, o que exigiu uma posição também inovadora da crítica.

A prática de uma compreensão antecipada supõe observar que, apesar da distância temporal, o sentido preliminar de um texto encontra-se presente nele próprio, como veículo transmissor da tradição, como fonte de elemento comum do discurso e do experimento lingüístico da representação da fala fixada na escrita, que desencadeia uma leitura comparativa à situação atual.

A essa questão histórica do exercício interpretativo, o professor paraense exemplificaa ao comentar a tragédia Édipo Rei, de Sófocles: “o sentido do texto é sempre o mesmo, pois que a ele retorno pela leitura, e sempre diferente, pois que se desencobre ao encontro de minha situação, nos limites da perspectiva cultural e histórica que ela me impõe, e que me possibilita compreendê-lo”. (NUNES, 1986, p.78)

Neste contexto, a compreensão é produtiva, porquanto imponho à dialética da pergunta e da resposta, em favor de minha própria historicidade, a interpretação como meio de descobrir o sentido do texto. Todavia, a ligação da obra ao hermeneuta não se abre apenas mediante a consciência histórica. Para uma abertura do caminho hermenêutico é necessária ressalvar a questão estética, correspondente à questão histórica, mas sem um grau de primazia de uma em relação à outra. A função estética, de cunho perceptual ou sensível, mobiliza os planos imaginativos e conceituais, que garantem o ingresso e o transporte do sentido nas obras literárias.

A experiência estética ${ }^{98}$, segundo Jauss (1979, p.46), não nasce da compreensão e interpretação do significado de uma obra ou pela reorganização do objetivo de seu autor. A

\footnotetext{
${ }^{98}$ No capítulo posterior, retomarei esta questão.
} 
experiência primeira de uma obra de arte efetua-se na reciprocidade com seu efeito estético: o fruir desinteressado suscita um novo interesse, que reprojeta a imaginação e movimenta a compreensão dos textos. Tal resultado possibilita ao receptor/intérprete observar a significação do mundo e da realidade circunscrita pela interpretação.

Neste aspecto, a relevância estética é a "relevância da forma como forma simbólica e o assinalamento do modo de existência da obra literária como discurso ficcional. A prática interpretativa não pode desaperceber-se do caráter ficto daquilo que compreende”. (NUNES, 1986, p.79)

Essa prática, envolta em uma completude cognoscitiva, anteriormente referida, aponta para a incongruência que parece existir entre o objeto ficcional do discurso literário e a suposta ligação com o real de suas enunciações.

No debate a esta questão, Benedito Nunes acompanha as reflexões desenvolvidas por Ricoeur em “A função Hermenêutica do Distanciamento”, constante de Interpretação e Ideologias. (1990, p.43-59)

Aliás, embora Nunes reconheça ter com Heidegger maior afinidade ${ }^{99}$, é com o filósofo francês que o arcabouço do crítico literário se faz mais próximo.

No ensaio referido acima, Ricoeur propõe encontrar uma solução para a antinomia defendida por Gadamer entre distanciamento alienante e experiência de pertença, discutidas nas três esferas da experiência hermenêutica, em Wahrheit und Methode (1960): estética, histórica e da linguagem - as quais explanei concisamente no item anterior.

Por distanciamento alienante entende-se a postura com base na qual é plausível a objetivação que impera nas ciências do espírito ou ciências humanas. Tal distanciamento, no entanto, ao se determinar o estatuto científico das ciências é, ao mesmo tempo, a destruição da relação essencial que nos faz pertencer e participar da realidade histórica da qual pretendemos construir em objeto. Neste sentido, ocorre a escolha subjacente ao título gadameriano, Verdade e Método: ou "praticamos a atitude metodológica, mas perdemos a densidade ontológica da realidade estudada, ou então praticamos a atitude de verdade, e somos forçados a renunciar à objetividade das ciências humanas”. (RICOEUR, 1990, p.43)

Ricoeur recusa esta alternativa e propõe ultrapassá-la ao introduzir a idéia de texto; para ele, uma noção positiva e produtora do distanciamento. O texto se define, dessa forma,

\footnotetext{
${ }^{99}$ Cf. "Meu caminho na crítica” (2005, p.300), por exemplo.
} 
como um paradigma do distanciamento na comunicação e revelador da própria historicidade da experiência humana, isto é, uma comunicação na e pela distância.

Sob este enfoque, cinco critérios, conjuntamente, constituem a textualidade: a efetuação da linguagem como discurso; a efetuação do discurso como obra estruturada; a relação da fala com a escrita no discurso e nas obras de discurso; a obra de discurso como projeção de um mundo; e o discurso e a obra de discurso como mediação da compreensão de si. (Cf. RICOEUR, 1990, p.44)

Benedito Nunes compartilha dessas mesmas características formadoras dos pressupostos da hermenêutica ricoeuriana. Por conseguinte, ao comentá-las, põem-se em relevo os traços formadores do ato interpretativo do professor paraense.

Na primeira parte desse estudo, descrevi, substancialmente, os principais pontos sobre os quais o pensamento de Ricoeur se consolida. Ressaltarei, agora, somente aqueles que se referem mais de perto à natureza da interpretação do texto.

De saída, Ricoeur afirma que a escrita não se constitui como a problemática única do texto; logo, não há como aproximar texto e escrita. É a dialética da fala e da escrita que promove um problema hermenêutico; dialética esta, construída sobre a de distanciamento anterior à oposição da escrita à fala, pertencente ao discurso oral. Desta forma, é no próprio discurso que se encontra a raiz de todas as dialéticas ulteriores. Entre a realização da linguagem como discurso e a dialética da fala e da escrita, há a efetuação do discurso como obra estruturada.

A objetivação da linguagem, nas obras de discurso, institui o requisito mais imediato da inscrição do discurso na escrita. A literatura é composta de obras escritas, conseqüentemente, de obras. Assim, o trinômio discurso-obra-escrita e o projeto de um mundo, o mundo da obra, fundamentam o cerne hermenêutico para o pensador francês.

Na sua teoria do texto, o discurso é definido como evento. Nesta assertiva, Ricoeur dialoga com o lingüísta francês Émile Benveniste ${ }^{100}$, para quem a lingüística do discurso e a da língua se erguem sobre unidades diferentes. No caso desta, o "signo" (de acepção fonológica e lexical) é o seu apoio; naquela, a frase é o esteio do discurso e comporta a dialética do evento e do sentido (ou significação).

${ }^{100}$ Cf. BENVENISTE, E. Problèmes de linguistique générale. Paris: Gallimard, 1976. 
O evento se realiza temporalmente e no presente, é, portanto, diferente da língua, que é virtual e fora do tempo. Com Benveniste, Ricoeur cita a "instância do discurso" para assinalar o irromper do próprio discurso como evento. Como o traço principal da frase é o predicado e não o sujeito, o discurso reporta-se a seu locutor, por meio de indicadores, como os pronomes pessoais. Neste caso, a "instância do discurso" é auto-referencial e o evento liga-se à pessoa daquele que fala; isto é, o evento versa no fato de alguém falar, exprimir-se ao pedir a palavra.

Como discurso é sempre discurso sobre algo e alude ao mundo que deseja representar, o evento, neste sentido, é o aparecer da linguagem de um mundo por intermédio do discurso. Se é no discurso que há trocas de mensagens, então o discurso possui, além do mundo, o outro, um interlocutor ao qual se endereça. O evento, assim, é o fenômeno temporal desse intercâmbio, a instauração do diálogo, que pode prorrogar-se ou cessar-se.

Essas características do discurso como evento, em conjunto, só despontam no percurso de efetuação da língua em discurso, na atualização de nossa competência lingüística em performance.

No entanto, se todo discurso se efetua como um evento, todo o discurso é compreendido como significação. Tal significação refere-se ao conteúdo proposicional. A articulação do evento com o sentido constitui a base do problema hermenêutico. A língua, ao incidir sobre o discurso, ultrapassa-se como sistema e executa-se como evento. Da mesma maneira, ao entrar no processo da compreensão, o discurso se ultrapassa, como evento, na significação: “essa ultrapassagem do evento na significação é típica do discurso enquanto tal. Revela a intencionalidade mesma da linguagem, a relação, nela, do noema com a noese”. (RICOEUR, 1990, p.47) Se a linguagem é uma ação significante, é exatamente em virtude dessa ultrapassagem do evento na significação.

Após a teoria dos atos da fala ${ }^{101}$, o noema do dizer não se pode desprender do seu momento ilocutório e perlocutório, já que estes dois aspectos intensificam a dimensão de ato do discurso oral e conservam-se unidos no conceito de significação.

Ricoeur assevera, no entanto, que, sem um exame específico da escrita, uma teoria do discurso não é uma teoria do texto. Um texto escrito é uma maneira de discurso, um discurso sob o modo de inscrição. Logo, as características de um discurso são também as do texto.

\footnotetext{
${ }^{101}$ Cf. AUSTIN, J.L. How to do things with words. Cambridge: Harvard University Press, 1975. e SEARLE, J.R. Speech-acts, an essay in the philosophy of language. Cambridge: Cambridge V.P., 1970.
} 
A concepção de evento lingüístico se localiza, antes, em uma série de polaridades dialéticas reunidas no duplo princípio de evento e significação e de sentido e referência. Tais polaridades dialéticas permitem afirmar que não se devem excluir da Hermenêutica as noções de intenção e diálogo, mas devem libertá-las da unilateralidade de um conceito não-dialético de discurso.

Se na semântica a frase é a primeira e última instância, na Hermenêutica é o texto, sobretudo o literário, que merece maior atenção e requer um olhar especial à referência. Para Ricoeur, além da estrutura e do sentido da obra, é preciso interpretar o mundo, que é a sua denotação. A Hermenêutica é a teoria que ajusta a circulação da estrutura da obra para o seu mundo. A referência, que não se restringe à obra científica - como quer Frege ${ }^{102}$-, atinge a obra literária e é delineada de um grau outro, diferente da linguagem corriqueira do discurso descritivo.

Especificamente na reflexão "O trabalho da interpretação e a figura do intérprete na literatura” (1986), Benedito Nunes centra a exposição na dimensão referencial da obra de ficção e de poesia, interessado que está em responder o problema, antes referido, da relação significativa interna da obra ao real.

O discurso tem a pretensão de representar o real; a escrita tenta distanciar-se dele ou desrealizá-lo. Pelo discurso, a linguagem projeta a forma de um mundo; pela escrita, a enunciação do discurso introduz-se no aspecto fictício de representação. Contudo, não há discurso “de tal forma fictício que não vá ao encontro da realidade, embora em outro nível, mais fundamental que aquele que atinge o discurso descritivo, constatativo, didático, que chamamos de linguagem ordinária”. (RICOEUR, 1990, p.56)

É no jogo dialético entre discurso e escrita no processo de estruturação da obra, que os textos literários efetuam uma nova espécie de referencialidade capaz de apontar para o ser-nomundo inscrito diante do texto.

Deste modo, interpretar uma obra é descortinar o mundo a que ela se refere, o mundo que se abre por meio da linguagem para os mecanismos gerais da existência humana, "tais como a tonalidade afetiva ou disposição anímica, a apropriação projetiva do mundo e a intersubjetividade”. (NUNES, 1986, p. 81)

${ }^{102}$ Cf. FREGE, G. Écrits logiques et philosophiques. Paris: Seuil, 1971. 
Tais mecanismos possibilitam a circulação da vida cultural e histórica no texto; circulação de mundo projetado na obra, do qual o leitor interage, posto que o texto só se transforma em obra no intercâmbio com este.

Estas observações retomam o limiar da pergunta formulada no final do primeiro item: como Nunes realiza a sua leitura hermenêutica? Realiza-a quando procura a verdade da obra $^{103}$ impressa como ficção; quando examina seu modus operandi, o seu como, revelador dessa verdade.

Realiza-a quando traduz para o discurso reflexivo o discurso dos textos literários, os sinais de natureza humana que eles carregam, manifestações de nós próprios e do mundo.

Esta tradução transforma o hermeneuta em "copartícipe da criação poética e do conhecimento teórico, a meio caminho das ciências humanas e da poesia - se é que ele também não está entre a poesia e a filosofia”. (NUNES, 1986, p.81)

Poesia e Filosofia são os dois campos em que se move, como já se assinalou, a crítica literária de Benedito Nunes. Crítica esta que perfaz, pelo ensaio, pelo mergulho além da superfície textual, o caminho hermenêutico. Tal caminho aspira percorrer o duplo trabalho da hermenêutica pretendida por Ricoeur (1990, p.43): desdobrar a dinâmica interna do texto e restaurar o poder de a obra se projetar para fora na representação de um mundo habitado por nós.

\section{I.4.3. Literatura e Filosofia}

A questão que Nunes se coloca diante dessas disciplinas abrange, antes de tudo, um repensar sobre o lugar da Literatura e da Filosofia dentro das Ciências Humanas. Tal debate já se iniciara desde a crise da metafísica - colocada em foco pela primeira vez na Crítica da Razão Pura (1781), de Kant, - e ao “aparecimento da Literatura” como linguagem singular, a qual se refere Foucault em Les mots et les choses (1966), ao comentar a organização das ciências humanas.

De fato, o que as aproxima é que, ambas, são obras de linguagem. Existem, portanto, apenas no modo operativo e poético, na acepção da palavra grega poiesis. No entanto, como obras de linguagem colocadas em ação, possibilitam distinguir o real para além do fenômeno imediato, empírico.

\footnotetext{
${ }^{103}$ Cf. BENJAMIN, Walter. "Les affinités électives” de Goethe. In : Oeuvres I - Mythe et violence. Paris: Les Lettres Nouvelles, Denoël, 1971, p.161-260.
} 
Na prática de leitura de Benedito Nunes, essas linguagens se intercomunicam e se enobrecem mutuamente: ingressa o poético na filosofia e ingressa o filosófico na poesia, mas sem igualar-se, sem perderem seus traços intrínsecos. Pode-se dizer que os limites entre a filosofia e a literatura são porosos, mas a filosofia não tem a última palavra.

Esse intercâmbio, não obstante, tem precedentes históricos e culturais que remontam à Antigüidade, marcados por confrontos e polêmicas. No texto "Filosofia e Literatura", constante em No tempo do niilismo e outros ensaios (1993), por exemplo, Nunes rememora a tradição desse diálogo, o que seria ocioso recapitular aqui.

No entanto, é preciso ressaltar a importância da Fenomenologia, em que, segundo ele, os laços da Filosofia e da Literatura se estreitam com mais vigor, em razão da intencionalidade que, ao deslocar a Filosofia para o campo da existência individual, também a deslocou para o da experiência literária e artística.

Dessa intencionalidade, ou da natureza que dela derivou, é marcante no pensamento do crítico paraense a chamada prática meditante, em Heidegger; a função desrealizante da consciência, em Sartre; e a experiência perceptiva do mundo em Merleau-Ponty, que serão comentadas mais à frente.

De qualquer modo, a poesia põe em relevo o tom indagador, no momento mesmo que a filosofia também caminha em direção ao poético. É desta forma que, lembra Nunes (1999a), autores como Fernando Pessoa, Rainer Maria Rilke, Paul Valéry buscam, no registro filosófico, a investigação do sentido da linguagem. Igualmente, filósofos como Heidegger, Sartre, Merleau-Ponty, Gaston Bachelard, Michel Foucault, Paul Ricoeur aprendem, com os poetas, os limites da palavra e a aporia do discurso.

Se, nessa ligação recíproca, a Filosofia utiliza a obra literária como tal objeto de sua indagação, a obra literária, por outro lado, "reverte sobre a Filosofia, da qual, ela, obra, se faz, como poética, a instância concreta, reveladora (ou desveladora) das originariamente abstratas indagações filosóficas”. (NUNES, 2005, p.295)

A Literatura sugere um método, a Filosofia pode corroborá-lo ou não; assim como a obra estudada igualmente pode oferecer uma luz ao filosófico.

A literatura é objeto de conhecimento filosófico porque é uma forma simbólica, porque há um domínio do simbólico, a que se atém o pensamento - ponto de convergência e de divergência da filosofia com a linguagem: o domínio do sentido das proposições, tal como especificado por Gilles Deleuze, em sua Logique du Sens". (NUNES, 2002, p.204) 
Neste sentido, uma possível Ciência da Literatura só poderia ser estabelecida quando da "competência” da Filosofia em lidar diretamente com o poético, da poiesis, da Dichtung intrínseca às formações verbais.

Por certo, o diálogo da Literatura com a Filosofia só se efetua no plano da Crítica, no entendimento interpretativo das obras. A Filosofia responsável por esse diálogo é a Filosofia Hermenêutica, a qual, por sua vez, “já opera com a noção de texto, que toma por pressuposto”. (NUNES, 1993, p.197)

Todavia, nesse caminho, há de se evitar o risco da dependência da obra à perspectiva hermenêutica do método filosófico, ou do risco, segundo Wellek \& Warren (2003, p.138), de se converter o texto literário em um "tratado filosófico".

Para Nunes (2002), refletir filosoficamente é assentar o foco da interpretação em um interesse interdisciplinar, uma vez que a filosofia se compreende como um discurso sobre outros discursos, para os quais também colabora com suas considerações. A abordagem filosófica de uma obra literária, entendida como forma, pode ser investigada, assim, sob três ângulos: a) a linguagem; b) as vinculações da obra com as linhas do pensamento históricofilosófico; c) "a instância de questionamento que a forma representa, em função de idéias problemáticas, isto é, de idéias que são problemas do e para o pensamento”. (p.205, grifos do autor)

\section{I.4.4. Guimarães Rosa}

Estes aspectos foram estudados, por exemplo, em Grande sertão: veredas, de Guimarães Rosa, em texto apresentado na conferência Literatura-Filosofia, no II Encontro Nacional de Professores de Literatura na Pontifícia Universidade Católica do Rio de Janeiro, em 1975, - publicado, depois, no Caderno 28 da PUC/RJ, em 1976. O mesmo ensaio consta do livro Teoria da literatura em suas fontes, vol. 1, com organização de Luiz Costa Lima cuja primeira edição é de 1975 - e serviu também como ilustração em "Meu caminho na crítica” (2005), quando se referiu ao romance roseano.

Ao seguir sucessivamente as três perspectivas citadas acima, Nunes mostrou que é possível ler a obra de Rosa, ao mesmo tempo, como Literatura e como Filosofia - relações que se enfatizam pela História. Tal História (e a temporalidade nela grafada) é revelada pelas 
formas de linguagem, as "formas simples" - examinadas por André Jolles ${ }^{104}$-, anteriores à "história da literatura, mas nela incidindo, na medida em que serviram de suporte ao desenvolvimento das eruditas”. (2002, p.206) A Lenda, a Saga, o Mito e a adivinhação (Charada ou Enigma), o Caso e a Sentença, o Conto e o Memorial são criados, fabricados e interpretados pela cultura. Não obstante, “tudo o que é criado, fabricado e interpretado é denominado pela linguagem” (p.206) - linguagem que, segundo Heidegger, é o alicerce da historicidade.

No “romance polimórfico” de Guimarães Rosa, encontramos na forma o caso, a adivinha ou enigma e a sentença. Presentes no tecido narrativo, pontuam “dúvidas” filosóficas, como o mito do pacto com o Demônio, "que cria, entre pergunta e resposta, um objeto de conhecimento absoluto”. (p.208) Esse mito modula a textura épica do romance, “do ciclo de aventuras narradas” e é "indissociável da indagação sobre a existência do Demônio, do mal em si, e de seu oposto, Deus - contraponto a que incessantemente se retorna”. (p.210)

Na urdidura da narração, os elementos épicos e míticos da linguagem encontram pontos de articulação com “determinadas linhas do pensamento histórico-filosófico”. (p.212) Desse diálogo, a reflexividade da narração, do discurso, entretece metáforas, "que são topoi do pensamento”, disseminadas em um discurso pontuado por traços conceituais de Heráclito, Agostinho, Plotino e a tradição hermética. Todavia,

\begin{abstract}
nem uma das linhas do pensamento histórico-filosófico - a neoplatônica, a agostiniana, a heraclitiana, e até mesmo a gnóstica, que nos pode sugerir a idéia da alma absoluta -, nem uma dessas linhas, que se entrançam à reflexividade tensa, enfaixa a perspectiva do narrador e do romance, reaberta a cada passo pelo dinamismo e pela mutabilidade da própria narração. (p.213)
\end{abstract}

A reflexão de Riobaldo, além dos topoi, introduz um terceiro termo, o Sertão-Mundo, meio dos opostos extremos - Deus e o Diabo -, que os une como faces complementares de uma mesma "realidade problemática”. (p.214)

Para Nunes, essa "realidade problemática”, o Sertão como espaço errático, no qual o homem se perde e se acha, “corresponde ao repetido motivo, que alenta a reflexão, do viver perigoso”. (p.214)

Na experiência/processo de leitura, caminhamos do epos ao mito; este, subordinado à indagação reflexiva que o "neutralizou”, nos leva a um ethos, "inquietação ética ou ética da inquietação".

${ }^{104}$ Cf. JOLLES, André. Formas simples. Trad. Álvaro Cabral. São Paulo: Cultrix, 1976. 
Nesse ponto, a filosofia é chamada “a nos servir de guia”, termo que Walter Benjamin usou quando da ponderação sobre as Afinidades Eletivas, de Goethe ${ }^{105}$. Filosofia como “instância de questionamento”, como abertura à questão do tempo, no qual a existência adquire densidade em seu ethos da inquietude:

\begin{abstract}
Os três tempos - o passado, o presente e o futuro - formam um só tempo que se distende, um só processo de temporalização, que conflui com o processo da própria narrativa. As carências do narrar - e a sua forçosa necessidade -, as carências desse contar dificultoso de Riobaldo, se desdizendo, depondo em falso, procurando o essencial e encontrando o acidental, dando o verdadeiro como plausível; todo esse contar ansioso do narrador em busca de si mesmo, que é contudo a única maneira que lhe permite ver e saber, alcançar a matéria vertente na retaguarda dos fatos, dar formato à vida, reunir e coligir o possível e o impossível, retraçar a ação e compreendê-la; toda essa penúria e toda essa força do narrar depende do tempo como movimento da existência finita em seu cuidado e em sua inquietude. (p.216)
\end{abstract}

O entrelaçamento do ethos e do mito, no romance, engendra uma encenação poética da narrativa humana, conduzida pela temporalidade como travessia da existência.

Segundo Nunes, é pela temporalidade, na “instância questionante do romance”, que há o encontro entre Literatura e Filosofia. Pela "verdade romanesca”, o drama da cultura ou do pensamento pode ser revisto em três momentos: a discriminação da literatura pela filosofia platônica; a estética moderna, de Kant a Hegel, ao situar o artístico ou o poético ao lado da filosofia; e o embaraço que Nietzsche pressentiu quanto a saber se "a filosofia é uma arte ou uma ciência”.

Com a linguagem, vista como primeiro plano da reflexão, a filosofia tende a perguntar-se se ela não é certa espécie de literatura. Ou melhor: ao deparar-se com a literatura, a filosofia caminha "ao encontro de si mesma, a fim de não somente interrogá-la, mas também, refletindo sobre um objeto que passa a refleti-la, interrogar-se diante e dentro dela”. (p.217)

No texto “A matéria vertente” (1983), essas ponderações foram igualmente tema de análise - sob novo ângulo - de Grande sertão: veredas. Benedito Nunes retomou a leitura hermenêutica na interrogação do texto, na busca da discussão que o mundo da obra indica ao pensamento.

\footnotetext{
${ }^{105}$ Cf. BENJAMIN, Walter. "Les affinités électives” de Goethe. In: Oeuvres I - Mythe et violence. Paris: Les Lettres Nouvelles, Denoël, 1971, p.161-260.
} 
Para o professor paraense, em cada olhar interpretativo o discurso do texto se reatualiza. Foi assim que Grande sertão: veredas - e o universo poético roseano - abriu-se em inúmeras exegeses.

Uma das primeiras recepções da obra de Rosa é um artigo de Nunes datado de 10 de fevereiro de 1957, publicado no Jornal do Brasil. A análise ressaltou, de saída, a surpresa causada pelo romance para, em seguida, comentar a construção da linguagem que, devido às inovações sintáticas e lexicais, pode ser aproximado, segundo ele, ao Macunaíma (1928) de Mário de Andrade. A técnica narrativa, o ritmo da prosa e a complexidade da trama fizeram o crítico afirmar tratar-se de um romance “extraordinário”, ainda que não ousasse, naquele momento, uma maior investigação da obra.

Em seu livro de ensaios mais conhecido, O dorso do tigre (1969; 1976, 2ª ed.), reuniu escritos anteriormente publicados na Revista do livro (“O amor na obra de Guimarães Rosa”, de 1964), e no Suplemento Literário do Estado de S. Paulo (“A viagem”, de 1966; “A viagem do Grivo”, de 1967; “Guimarães Rosa e a tradução”, de 1963; e Tutaméia, de 1967).

No primeiro estudo, o tema do amor em João Guimarães Rosa é entendido em uma

perspectiva mística heterodoxa, que se harmoniza com a tradição hermética e alquímica, fonte de toda uma rica simbologia amorosa, que exprime, em linguagem mítico-poética, situada no extremo limite do profano com o sagrado, a conversão do amor humano em amor divino, do erótico em místico. (NUNES, 1976, p.145)

Em “A viagem” e “A viagem do Grivo”, explora o “motivo da viagem” como presença constante na literatura roseana, de Sagarana (1946) a Primeiras estórias (1962). O viajar se insinua na estrutura, na temática, na travessia/existência - "viagem que forma, deforma e transforma e que, submetendo as coisas à lei do tempo e da causalidade, tudo repõe afinal nos seus justos lugares”. (1976, p.178)

“Cara-de-Bronze”, de Corpo de baile (1956), segundo Nunes, é a narrativa em cujo tecido poético a viagem se desenha com maior intento. São, na verdade, duas linhas que se movem, uma em função da outra: a da "narrativa propriamente dita, como unidade literária maior, (...) contando-nos o que se passou nesse Urubuquaquá entre um certo Cara-de-Bronze e um certo Grivo"; e o da "narrativa da narrativa, da viagem da viagem, cheio de subentendidos, por trás do qual fica a verdadeira estória, que somente ao Cara-de-Bronze foi contada”. (1976, p.185, grifos do autor) 
“Guimarães Rosa e a tradução” comenta a versão francesa, de J. J. Villard, de três novelas de Corpo de baile (1956), publicadas em 1960, pela Éditions du Seuil, com o título de Buriti e prefácio de Xavier Dominingue.

A difícil tarefa de traduzir a linguagem de Guimarães Rosa foi, segundo Nunes, o grande problema de Villard, pois este reduziu a força poética do texto, trabalhou com uma estilística estranha a Rosa e não respeitou a “concepção-de-mundo”, do autor brasileiro.

Alertou, no fim, o professor paraense, que aqueles que quiserem traduzir a obra de João Guimarães Rosa devam ter o "mesmo cuidado crítico, a mesma atenção interpretativa e a mesma capacidade inventiva daqueles que têm traduzido Joyce”. (1976, p.202)

Na última reflexão, Tutaméia foi apresentada como o livro que contém "estórias" entendidas como casos exemplares de fábula ou de mito. Nas quarenta estórias, o tom predominante é o da comédia, ajustadas pelos quatro prefácios - "Aletria e hermenêutica”, "Hipotrélico”, “Nós, os tremulentos” e “Sobre a escova e a dúvida”, - “que muitas insídias, surpresas e revelações encerram para o intérprete sequioso da obra de Guimarães Rosa”. (1976, p.205)

De acordo com Nunes, as estórias e os prefácios são poeticamente ordenados; nas estórias, a linguagem revela o plano de criação e de recriação; os prefácios complementam ou contrapõem esse plano, em um jogo de linguagem metalingüístico. Em ambos, a ironia do pensamento, o saber reflexivo. Tutaméia é, assim, a "leitura geral da vida (..) episódios de divina e altíssima comédia, mito em que nos compreendemos sem nada compreender”. (1976, p.209-210)

Para além dos artigos de O dorso do tigre (1976), é notória a participação de Benedito Nunes em congressos, simpósios, comunicações sobre Guimarães Rosa. Pode-se destacar, desses seus estudos em geral, o texto “O mito em Grande sertão: veredas” (1998), apresentado no I Seminário Internacional Guimarães Rosa, em Belo Horizonte, realizado pelo Centro de Estudos Luso-afro-brasileiros e pelo Programa de Pós-graduação em Letras da PUC Minas, em agosto de 1998. No mesmo ano, os ensaios foram publicados na Revista Scripta (vol. 2, n 3), em um número especial sobre o autor mineiro ${ }^{106}$.

\footnotetext{
${ }^{106}$ As várias perspectivas de estudo do Seminário mereceram um comentário crítico de Maria Cristina Elias "Os não-lugares de Rosa” -, publicado no Dossiê Cult - Literatura Brasileira, com organização de Marcelo Rezende. São Paulo: Editora Bregantini, 2004, p.66-71.
} 
O professor paraense teceu considerações sobre o estilo mítico de contar, "que começa na poesia para acabar no mito” (p.33). A conjunção entre poesia e mito explica como o romance Grande sertão: veredas pode ser entendido como “mitomórfico”.

Segundo ele, o sertão, que “está em toda parte e em lugar nenhum”, funda o “mito de origem” ou a "origem do mito" (p.34) da narrativa. Todos os elementos citados “do chão ou da terra” (p.37) são considerados signos, cujo significado excede sua materialidade, estão “fora de si”. O mundo natural, assim, somente se manifestaria a “posteriori, já mitificado”. (p.37)

Nesse ponto, Nunes faz uma aproximação da narrativa de Rosa à “descrição da coisa como tal” feita por Martin Heidegger nos seus escritos tardios. Heidegger, ao propor uma visão mitomórfica do mundo, compreende que seus elementos reúnem “quatro parcelas - céu e terra, mortais e imortais - em que se desdobra à unidade primeira, graças à força originária da palavra poética”. (p.37) Com a prevalência da “palavra poética”, a presença de qualquer uma das quatro parcelas determina a das demais, o que confere ao mundo a qualidade de “habitável residência humana”.

Ao final, conclui que, em Grande sertão: veredas, a habilidade de "abrir o longe no perto e o distante no próximo" decorre do arrebatamento do mito pela força da palavra poética.

Esta mesma idéia encerra o texto "De Sagarana a Grande sertão: veredas", presente em Crivo de papel (1998), originariamente uma Conferência feita para a Universidade Federal da Bahia, na Academia Bahiana de Letras, em novembro de 1996.

Em sua reflexão, “digressiva e um tanto memorialística” (1998, p.248), Nunes teve como proposta reexaminar as várias possibilidades interpretativas que a leitura da herança literária de Guimarães Rosa invoca.

A aproximação com Sagarana, conta-nos, surgiu por meio do rastro de Corpo de baile, intercomunicante com o do Sertão das Veredas:

Li Grande Sertão: Veredas em 1956, ano em que surgiu, e logo depois, antes, muito antes de ter conhecido Sagarana, já publicado fazia uma década, li o comparsa novelístico do retumbante romance, Corpo de baile. Acho que esse foi um repetido incidente bibliográfico, de Norte a Sul do país, em nossa geração. Ao contrário do título de que parti, iríamos de Grande Sertão: Veredas a Sagarana, e não de Sagarana a Grande Sertão: Veredas. Sem o saber, estávamos, os então leitores com menos de trinta anos, reproduzindo um fato da recepção crítica da obra de Rosa na época. (NUNES, 1998, 247) 
Em uma “concepção autoral”, aproxima Unamuno a Guimarães Rosa, pois este coligava poesia e religião, apesar dos valores diferenciados com os quais estas se relacionam. O poético e o religioso se interligam, segundo o professor, ao mito. Neste ponto, recordou o “tema da viagem”, do qual se ocupou por volta de 1962, e que mostra esta “inseparabilidade”.

Da mesma forma, comentou outros de seus trabalhos da década de 60 [que se encontram reunidos no Dorso do tigre (1969)], como a questão do amor em Grande sertão: veredas (1956); o neoplatonismo presente "em diversos topoi (figuras) sobre a alma e o interior conflituoso de Riobaldo” (p.259); o plano metafísico e as origens ocultistas do romance.

Após explicar a relação de viagem, “transunto da aventura humana” (p.254), interrompe a reflexão para expor o único encontro que teve com Guimarães Rosa, ocorrido no gabinete do escritor, na antiga sede do Itamarati, no Rio de Janeiro, em fevereiro de 1967.

Esta conversa, no entanto, já havia sido publicada no Suplemento Literário de Minas Gerais, em 23 de novembro de 1968, em texto escrito em Paris, datado de 9 de setembro do mesmo ano.

Recentemente, em “Guimarães Rosa quase de cor” $(2006)^{107}$, relembrou o mesmo diálogo no evento Homenagens a Guimarães Rosa, apresentado na Universidade de São Paulo, no dia 17 de maio de 2006. Em 21 de setembro, a mesma anotação é lida na X PAN Amazônica - Feira de Livros -, realizada em Belém.

Apesar do fio narrativo que os liga, são três momentos em que Nunes revelou aspectos diferenciados do contato com o autor de Sagarana. Desses, o artigo do Suplemento Literário é o mais rico em detalhes:

(...) Guimarães Rosa interessava-me pouco ou quase nada como indivíduo. Absorvia-o na sua obra, que me absorvia. Um contato pessoal com o escritor me parecia supérfluo, e essa opinião, fortalecida pela timidez, prevaleceu até o dia em que a força das circunstâncias me impeliu até ele. Tudo aconteceu de repente, graças a caminhos e desvios imprevistos. Como numa novela do próprio Guimarães Rosa, o acaso causalidade se deram as mãos, coniventes. (...)

Haroldo Maranhão (...) compeliu-me a telefonar de seu escritório para o Itamarati. A mania que tenho de adiar tudo quanto me parece grave ou importante valeu-se da proteção do telefone. Anunciei, então, a Guimarães Rosa, meu propósito de visitá-lo dali a dois ou três dias, conforme lhe conviesse. E já respirava aliviado com esse honroso adiamento, quando escutei-o, intimativo, dizer que a visita tinha que ser feita naquela mesma tarde. (NUNES, 23 nov. de1968, Suplemento Literário, v.3, nº 117, p.1-2)

\footnotetext{
${ }^{107}$ Com ligeiras modificações, esse texto é publicado com o nome de "O autor quase de cor: rememorações filosóficas e literárias”. In: Cadernos de Literatura Brasileira - Guimarães Rosa. São Paulo: Instituto Moreira Salles, 2006, p.236-244.
} 
Já no primeiro instante da reunião, Guimarães Rosa entrega a Nunes uma cópia datilografada de Tutaméia, cujo título, entre parênteses, Terceiras Estórias, chama logo a atenção do professor paraense: “- Por que Terceiras Estórias? As segundas, onde é que estão? - Ah! isso é mistério. Por enquanto, nada posso revelar”. (idem)

Em seguida, pede que o visitante leia o prefácio “Aletria e Hermenêutica”. Os textos de Tutaméia eram conhecidos previamente pelo crítico, que os havia lido no jornal médico Pulso. Mesmo assim, na tensão da hora, a opinião sobre o original - como a convergência entre o imaginário e o reflexivo, o teórico e o poético -, foi um ensejo para Guimarães Rosa desenvolver a respeito da incorporação da filosofia em sua literatura, a propósito dos segmentos de Sexto Empírico, empregados em um dos prefácios de Tutaméia.

Explicou Rosa sobre o aproveitamento lúdico de um trecho de Platão, que nem "os especialistas em História da Filosofia poderiam distingui-los” (2006 - inédito); do jogo poético, cuja chave-verbal “oculta”, na expressão “Ai, Zé, opa?”, significa a Poesia; de como a literatura, para ele, era "ato de escrita e a escrita como oração e sacrifício, purifica o homem, completando-o e salvando-o”. (2006 - inédito)

Da conversa entre eles, a poesia, a religião e a filosofia tomaram corpo no tecido ficcional, quando ambos recordaram, por exemplo, do tema da viagem, presente na obra roseana de Sagarana a Grande sertão: veredas; de Corpo de baile a Tutaméia.

Por fim, Benedito Nunes declarou:

\begin{abstract}
Não me arrependi do encontro com Guimarães Rosa. Arrependi-me, e muito, por havê-lo retardado. (...) Numa tarde de outono, em Paris, remexendo na caixa de um bouquinista, onde havia grande sortimento de Les fleurs du mal, descobri Diadorim, versão francesa de Grande sertão: veredas, por trás de uma edição dos poemas de Baudelaire. À falta do original, de que tinha saudade, comprei o volume e li-o durante a noite. Só terça-feira, 21 de novembro, três dias depois deste novo encontro casual com Guimarães Rosa, às margens do Sena, vim a saber que ele morrera nessa mesma noite. (NUNES, 23 nov. de 1968, Suplemento Literário, v.3, nº 117, p.1-2)
\end{abstract}

No texto “Guimarães Rosa quase de cor” (2006), assinalou trabalhos recentes sobre a aproximação da filosofia e da literatura, como o de Hygia Therezinha Calmon Ferreira (1991), de Sonia Maria Viegas Andrade (1985); de Pierre Macherey (1990), de Hector Olea (1992); de Francis Uteza (1994); e de Maria Heloísa Barros Noronha (1988) ${ }^{108}$.

108 Cf. FERREIRA, Hygia Therezinha Calmon. João Guimarães Rosa: As sete sereias ao longe. Tese de Doutorado. São José do Rio Preto, 1991; ANDRADE, Sonia Maria Viegas. A vereda trágica de "Grande sertão: veredas”. São Paulo: Edições Loyola, 1985; MACHEREY, Pierre. À quoi la literature? Presses Universitares de France, Paris, 1990; OLEA, Hector. Enigma no nô da imagem: os módulos poéticos no “conto crítico" roseano, 1992 (inédito); UTEZA, Francis. Guimarães Rosa: metafísica do Grande Sertão. São Paulo: Edusp, 1994; 
Já em "De Sagarana a Grande sertão: veredas”, do Crivo de papel (1998), a revisitação da receptividade à obra de Rosa - de Álvaro Lins a Francis Uteza, passando por Cavalcanti Proença, Oswaldino Marques, Franklin de Oliveira, Antonio Candido e Consuelo de Albergaria -, culmina com um modelar exercício de discussão da crítica, entendida como “ato de permanente e renovada leitura”. (p.261- grifo do autor).

Esta sua concepção a respeito da crítica, já esboçada nos textos-chave com os quais iniciei esta explanação - “Ocaso da literatura ou falência da crítica?” (1999a), “Crítica literária no Brasil, ontem e hoje” (2000) e “Meu caminho na crítica” (2005) -, abre perspectivas para um repensar do papel do crítico e a inesgotabilidade das interpretações. Tais assuntos, imprescindíveis para se entender a escritura analítica de Benedito Nunes, serão examinados, com mais proeminência, a seguir. 
"Eu diria que as grandes conquistas de nossa cultura - letrada e científica - seriam a copernicana (o homem sabe que não é mais o centro do universo), a freudiana (a consciência não é tudo), a darwiniana (que reforça isso) e a filosófica heideggeriana (você não tem a verdade). O grande trauma do homem é ter perdido a relação que tinha com o Absoluto e não poder preencher isso”.

(Benedito Nunes) 
CAPÍTULO II

\section{A crítica crítico reflexiva de Benedito Nunes}

No capítulo precedente, procurei delinear, em substância, o pensamento de Benedito Nunes. Com este propósito, seus principais escritos foram revisitados e ressaltados como a 
dimensão de um corpus ensaístico intenso e profícuo, marcado pelo princípio hermenêutico da leitura interpretativa em constante transformação.

Das observações realizadas, proponho discutir, neste momento, quatro aspectos que, julgo, merecem ser destacados do amplo painel desenhado:

1) a crítica definida como tensão entre a escrita dos escritores e a leitura dos críticos;

2) o confronto de idéias estéticas e poéticas;

3) o discurso teórico-crítico marcado por uma postura filosófica;

4) o procedimento da historicização e o uso constante do ensaio.

Embora de forma alguma componham o cerne único da sua obra, tais traços, em conjunto, constituem essencialmente a característica da produção de Nunes. Uma última marca - a linguagem na divisa entre o conceitual e a criação de imagens - será tema do terceiro capítulo.

Esse recorte, não obstante, só se justifica como exercício de uma interpretação que assume uma posição similar à da própria interpretação-objeto, em um indelével jogo de espelhos decorrente da perpétua atividade de interpretar. Em outros termos: ao tangenciar o discurso de Nunes, ele mesmo um empreendimento hermenêutico, pretende-se comentá-lo e acrescentar reflexões, pois sempre há a possibilidade de outros desdobramentos, intrínsecos do ato de ler.

\section{1. A questão da leitura e a leitura em questão: tensão entre a escrita dos escritores e a leitura dos críticos}

Ao apresentar Benedito Nunes, antes de sua conferência ${ }^{1}$ denominada “Crítica literária no Brasil, ontem e hoje” (2000), Flávio Aguiar divide em três momentos a obra do professor paraense: 1. os escritos de fundamentação: por exemplo, Passagem para o poético (1986); 2. os de interpretação: estudos de $O$ dorso do tigre (1969) e No tempo do niilismo e outros ensaios (1993); 3. os de edição: publicação dos poemas de Mário Faustino (1985) e a edição crítica de A paixão segundo G. H. (1996), de Clarice Lispector.

\footnotetext{
${ }^{1} \mathrm{O}$ texto da conferência e de sua respectiva apresentação é uma das exposições pertencentes a Rumos da crítica (2000), resultado de um ciclo de palestras que constituíram o programa Rumos da Literatura e da Crítica do Itaú Cultural, ocorrida em 1999.
} 
Conquanto Aguiar declare que tal divisão não pode ser entendida de modo estanque, é preciso salientar o risco em que toda classificação incorre. No caso, a obra de Nunes dificilmente se deixa enfaixar de modo a pertencer a esta ou aquela linha. O que se percebe, por certo, são nuances de uma escritura que, ao não aceitar a estéril generalização, realiza-se como invenção e expressão em diferentes momentos no espaço da crítica.

Basta assinalar que sua práxis da interpretação nasceu no solo literário, em cuja fonte a filosofia - a Filosofia Hermenêutica, importante lembrar - incide como linguagem, no reconhecimento da literatura como “experiência do possível”. (NUNES, 1993, p.199 - grifo do autor)

Assim, o diálogo literatura e filosofia se institui como campo de sua instrumentação e perpassa seu discurso crítico de modo a compor um fio ao qual seu raciocínio se prende. Nas suas palavras:

Não sou um duplo, crítico literário por um lado e filósofo por outro. Constituo um
tipo híbrido, mestiço das duas espécies. Literatura e filosofia são hoje, para mim,
aquela união convertida em tema reflexivo único, ambas domínios em conflito,
embora inseparáveis, intercomunicantes. (NUNES, 2005, p.289)

Diante dessa posição, talvez seja pertinente perguntar o que isso representa, qual o lugar e a importância que ocupa tal analítica dentro do quadro instável em que se desenvolveu a crítica literária brasileira. O adjetivo instável, vale dizer, não possui um qualificativo negativo; antes, revela a natureza complexa do tema, merecedor de diversas e, por vezes, polêmicas exegeses ${ }^{2}$.

Por outro lado, pode-se indagar, com Costa Lima (2000, p.17), se um crítico, ou a crítica literária em si, tem lugar definido, já que, como constata, esta é apenas um horizonte de que “seus praticantes tão-só estão próximos ou distantes”. Em poucas palavras:

O crítico não é aquele que, por força de uma instrumentação técnica, "mostra” aos leigos o que eles por si não saberiam ver, senão aquele que usa de uma instrumentação, só às vezes técnica, para tornar visível a presença de uma propriedade que, em tese, seria a todos acessível. ${ }^{3}$

\footnotetext{
${ }^{2}$ Dos inúmeros exemplos, o mais recente é o livro Estados da crítica, organizado por Alcides Cardoso dos Santos, que reúne ensaios do Grupo de Estudos em Crítica Contemporânea (GRECC), da FCL/UNESPAraraquara. São Paulo: Ed. UFPR/Ateliê, 2006.

${ }^{3}$ Igual percepção pode-se encontrar em Barthes (2003, p.161): “(...) a tarefa crítica (...) não consiste em 'descobrir', na obra ou no autor observados, alguma coisa de 'escondido', de 'profundo', de 'secreto', que teria passado despercebido até então (por que milagre? somos nós mais perspicazes do que nossos predecessores?), mas somente em ajustar (...) a linguagem que lhe fornece sua época (...) à linguagem, isto é, ao sistema formal de constrangimentos lógicos elaborados pelo próprio autor segundo sua própria época”.
} 
O crítico, pois, seria aquele que, ao ler a obra literária, compartilharia com outros leitores sua experiência de leitura do texto. De fato - e não é novidade -, são as diferentes formas de ler o fenômeno literário que propiciam as diversas interpretações textuais ${ }^{4}$. Basta recordar a atualidade da assertiva de Merleau-Ponty (1989) de que só encontramos nos textos aquilo que colocamos neles. Ou o vaticínio de Paul de Man (1971): a literatura, por sua própria natureza, condena o crítico a certa cegueira e só lhe permite poucos vislumbres.

Ao descortinar as camadas da linguagem, ao investigar o possível sentido que se produz em cada dobra, o crítico concretiza sua prática do discurso literário pela leitura. Prática esta também teórica, posto que a ação de interpretar envolve princípios e conceitos. Da mesma forma, a crítica e a teoria não se isolam da história literária; são tênues as fronteiras dessas vertentes que se interpenetram e não podem ser vistas separadamente ${ }^{5}$.

Já segundo Barthes (2003, p.230-1), “passar da leitura à crítica é mudar de desejo, é desejar não mais a obra, mas sua própria linguagem. Mas por isso mesmo, é devolver a obra ao desejo da escritura, do qual ela saíra”. Para essa crítica que se assume como escritura ${ }^{6}$, a crítica-escritura é o momento em que o discurso do crítico se torna inventivo e o "texto criticado se torna pré-texto para uma nova aventura de linguagem”. (PERRONE-MOISÉS, 1978, p.12-3)

Jen-Yves Tadié (1992, p.9) pondera que a crítica torna-se leitura e escrita porque, principalmente, a obra de arte se modifica e a "interpretação faz parte do texto". Desse modo, no processo crítico, leitor e leitura são entendidos como instâncias de estruturação da própria obra, seja o "leitor implícito", de Booth-Iser,
seja o "arquileitor”, de Riffater-Genette, seja o "releitor” de intertextualidades de
Kristeva-Barthes, enfim, não somente uma leitura crítica, fundada no instrumental
filológico, na crítica histórica, na leitura imanente ou na análise estilística, mas uma
crítica da leitura que decorre, em grande parte, da consciência literária da literatura.
(BARBOSA, 1996, p.61)

No sentido vulgar, o trabalho do crítico é uma tentativa de selecionar as partes relevantes do texto (o verbo grego Krinein significa, em seu sentido primeiro, "separar para

\footnotetext{
${ }^{4}$ A respeito dos diferentes tipos de leitura - com as respectivas abordagens - e de leitores Cf. ECO, Umberto. Os limites da interpretação. Trad. Pérola de Carvalho. São Paulo: Perspectiva, 2000, p.1-19.

${ }^{5}$ Cf. WELLEK, René e WARREN, Austin. A teoria, a crítica e a história literária. In: Teoria da literatura e metodologia dos estudos literários. Trad. Luis Carlos Borges. São Paulo: Martins Fontes, 2003, p.36-45. É preciso salientar, também, o papel da recepção das obras na relação entre a historicidade do fato literário e a História geral discutida em JAUSS, Hans Robert. A literatura como provocação (história da literatura como provocação literária). $2^{\mathrm{a}}$ ed. Trad. Tereza Cruz. Lisboa: Passagens, 2003.

${ }^{6}$ Cf. BARTHES, Roland. Le degré zéro de l'écriture. Paris: Du Seuil,1972.
} 


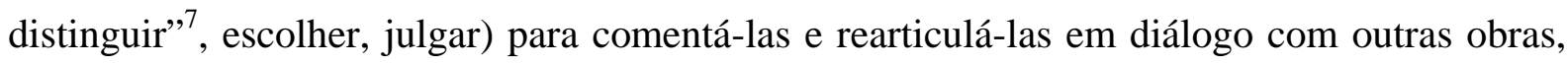
autores, linguagens, sem limite de espaço e de tempo. No entanto, pode ser igualmente a perspectiva de uma atividade de recriação, tradução e reatualização que nasce por meio de uma leitura singular, tal como a que Walter Benjamin empreendeu ao ler os românticos Schlegel e Novalis ${ }^{8}$ e a poesia de Baudelaire ${ }^{9}$.

Claro está que a importância dessas observações tem desdobramentos outros que, por ora, deixo em aberto.

Interessa-me aqui tão-somente mostrar que a questão acerca da leitura - e, portanto, desta como instância crítica - perpassa grande parte dos ensaios de Benedito Nunes. Se a dialogação literatura e filosofia é a marca de tal leitura-crítica, é preciso, no entanto, esclarecer quais os princípios e os limites desse intento.

Em “Ética e leitura”, um dos títulos de Crivo de papel (1998), por exemplo, ele põe em cena esse assunto ao afirmar que a "prática da leitura seria um adestramento reflexivo, um exercício de conhecimento do mundo, de nós mesmos e dos outros”. (NUNES, 1998, p.175) Essa mesma idéia, aliás, é o que responde à reflexão de George Steiner (1988) se não valeria a pena dispensar a crítica e deixar vir à tona as “reais presenças” das obras literárias:

\begin{abstract}
Mas como reconhecer essas presenças reais (...), se muitos de nós se omitem [sic] ao dever principal, suporte da ética da literatura, de transmitir aos nossos estudantes o prazer da leitura dos textos: prazer que, adestrando reflexiva e criticamente a mente e o coração de quem o experimenta, prolonga-se em descoberta de nós mesmos e do mundo? (NUNES, 1999a, p.20)
\end{abstract}

Na esteira de Ricoeur (1990), de quem absorve o conceito de texto - já comentado no capítulo anterior $^{10}-$, o ato de ler, para Nunes, é o movimento especular em que o leitor, ao compreender o texto, compreende-se a si próprio. Nesta mobilização, a hermenêutica que a obra do discurso (seja poesia, seja prosa) nos oferece é a da experiência do mundo do texto, ou do texto transformado em mundo, caracterizado por uma referência outra, distante da subjetividade do autor.

\footnotetext{
${ }^{7}$ CF. LEÃO, Emmanuel Carneiro. Aprendendo a pensar. Rio de Janeiro: Vozes, 1977, p.164.

${ }^{8}$ Cf. BENJAMIN, Walter. O conceito de crítica da arte no romantismo alemão. Trad. Márcio Seligmann-Silva. São Paulo: Iluminuras, 1993.

${ }^{9}$ Cf. BENJAMIN, Walter. Charles Baudelaire - um lírico no auge do capitalismo. In: Obras escolhidas. Vol. III. $2^{a}$ ed. São Paulo: Brasiliense, 1991. Além dos comentários na contracapa, João Alexandre Barbosa também escreve a respeito da importância dessa crítica de Benjamin em As ilusões da modernidade. São Paulo: Perspectiva, 1986, p.20-3.

${ }^{10}$ Cf. partes I.4.1 (Breves interfaces do pensamento hermenêutico), p.88-9 e I.4.2. (Hermenêutica e crítica literária: o intérprete Benedito Nunes), p.95-8.
} 
O crítico-leitor, ao apreender a obra, projeta no seu discurso a prática dessa linguagem, ponto de encontro da literatura e da filosofia, pois o pensamento, ao demandar essa linguagem, já se interpretou nela. Como interpretante-leitores, pode-se dizer que "a literatura pensa, não apenas no sentido (...) de extrair a Filosofia implícita de certas obras literárias (...), mas, também, no sentido do efeito anagógico, conversor, propiciado pelo ato de sua leitura”. (NUNES, 2005, p.303-4)

Sob este ângulo, é possível encontrar, em Nunes, o testemunho de uma leitura primeva, advinda de imediato do embate com a obra literária, como quando descreve sua reação ao episódio da morte de Diadorim (ROSA, 1986, p.529-0):

\begin{abstract}
Até hoje, depois de tantos anos da primeira leitura de Grande Sertão: Veredas, não posso deixar de emocionar-me nesta passagem. Compartilho o sofrimento do outro para quem nenhuma consolação, humanamente falando, é possível. E compreendo a ação do romance, compreendendo-me (juízo) através dela, em minha condição de sujeito, fadado ao sofrimento. O movimento completou-se fora do livro, a experiência (estética) do conflito prolongada na experiência de vida do leitor (Katharsis). (NUNES, 1998, p.184)
\end{abstract}

Compreender a obra é, assim, tentar alcançar a singularidade de sua linguagem, perceber que esta é capaz de se abrir em múltiplos sentidos, cuja interpretação pode transformar o texto em um objeto de juízo estético ou reflexivo.

Por certo, sua leitura crítica não se limita à experiência estética, já que é próprio desta trabalhar sem conceitos ${ }^{11}$. Há, sim, em um primeiro momento, para dizer como Coleridge ${ }^{12}$, uma “suspensão da descrença” (willing suspension of disbelief). Ou seja, o receptor é enlaçado pelo texto que apresenta algo diferente da sua expectativa. Ao aceitar capturar-se por inusitados meandros textuais, passa a incorporar essa nova experiência e amplia seu repertório de conhecimento.

Entretanto, tal conhecimento, advindo do apelo estético, é apenas uma reação do receptor, um comportamento manifestado diante de um estímulo e, portanto, ainda não é de fato algo a respeito do qual se possa estabelecer leis.

Em que momento, então, há a passagem da experiência estética à crítica propriamente dita? Para Benedito Nunes, é quando ocorre uma tensão entre o texto e o leitor, tensão esta

\footnotetext{
${ }^{11}$ Cf. COSTA Lima, Questionamento da crítica literária. In: DIAS, Ângela et al. Função da crítica. Revista Tempo Brasileiro, $\mathrm{n}^{\circ}$ 60, Rio de Janeiro, janeiro-março de 1980, p. 111.

${ }^{12}$ Cf. COLERIDGE, S.T. Biographia literaria or biographical sketches of my literary life and opinions. London, New York: J. M. Dent, 1956, p.168-9.
} 
avivada por uma escritura inovadora, criativa, no limite extremo que exige do crítico-leitor um novo olhar interpretativo, reflexivo:

Se a experiência do crítico reside na leitura que faz da obra, a experiência do escritor deriva de sua escrita. De uma e de outra experiência, concordante ou discordantemente, derivam mudanças, ora pacíficas, ora conflitivas, da literatura. Os momentos literários mais fecundos, aqueles que fazem história, talvez sejam os de maior tensão entre a escrita dos escritores e a leitura dos críticos. (NUNES, 2000, p.54)

A resposta a essa passagem, todavia, ainda não esclarece de todo esta problemática. Como prerrogativa inicial, há de se esclarecer a relação entre a Estética e a Crítica e de como a leitura de Nunes a respeito delas desemboca na problemática da confrontação filosófica e artística. Ou antes, deve-se deixar claro que o crítico paraense se refere à experiência estética em uma dimensão ontológica, da qual se esboça a leitura hermenêutica empreendida por ele.

Sem me ater a um arrazoado excessivo, é necessário pontuar, entretanto, essas questões sem perder de vista a contribuição do pensamento de Benedito Nunes para caracterizá-las. Isto porque, ao acompanhar suas reflexões, estar-se-á à procura de melhor apreender seus passos.

\section{1.1. Preliminares Estéticas e Críticas ${ }^{13}$}

Em texto recente ${ }^{14}$, Mario Perniola (2006) delineia o conceito de horizonte estético como aquele composto por quatro tipos de investigação - o belo, a arte, o conhecimento sensível e a educação - e defende que tal horizonte é marcado por um dinamismo constante, manifestado por conflitos abertos e transpassado por tensões e atritos.

Sob este prisma, a situação estética contemporânea pode ser caracterizada por duas vertentes opostas: uma, mais expansiva, é descrita como "a viragem cultural da estética" (p.108 - grifo do autor), por meio da qual esta é identificada com o estudo da cultura. Nessa linha, Perniola destaca o trabalho da estética cultural de Jakob Burckhardt, do historiador Georg Mosse, dos sociólogos Plessner e Gehlen, de Umberto Eco, de Watsuji, de Pierre Bourdieu, entre outros.

\footnotetext{
${ }^{13}$ Não se pretende, e nem é esse o objetivo do trabalho, detalhar uma história da Estética ou da Crítica. O que se examina, neste item, são questões centrais do pensamento estético e crítico que, de uma forma ou de outra, contribuíram para assinalar o discurso de Benedito Nunes. Dessa forma, justificam-se as ausências de autores da tradição filosófica, bem como as inevitáveis lacunas decorrentes do intento.

${ }^{14}$ Cf. PERNIOLA, Mario. Expansão e fragmentação do horizonte estético. In: Revista Diacrítica. Série Filosofia e Cultura, n 20/2. Trad.Vítor Moura Braga: Universidade do Minho - Centro de Estudos Humanísticos, 2006, p.107-118.
} 
Em uma segunda tendência, de fragmentação, há uma “desconstrução da estética”, em que as suas concepções fundamentais perdem sua natureza de unidade e são "inseparáveis das línguas” (p.115) nas quais são expressas. Como exemplo, o autor italiano cita o Vocabulaire Européen des Philosophes. Dictionnaire des Intraduisibles (2004), dirigido por Bárbara Cassin, inspirado no Vocabulário das Instituições Indo-Européias (1995), de Émile Benveniste.

No livro A estética do século XX (1998), Mario Perniola já havia apresentado cinco conceitos essenciais no núcleo dos quais se podem traçar contribuições mais expressivas a esta disciplina: “a vida e a forma”, remetidos a Kant; “o conhecimento e a ação”, referidos a Hegel; e o "sentir”, aludido a Nietzsche. Para ele, a estética se move contemporaneamente em decorrência desses contributos, ainda que haja a expansão e a fragmentação do seu horizonte acima aludido.

A referência a Mario Perniola tem como finalidade mostrar que, de forma modelar, a preocupação com a Estética excede os limites de tempo e de espaço e se torna um interesse teórico em não poucos pensadores.

A contribuição de Benedito Nunes acerca desse assunto tem sido a de considerar a Estética como Hermenêutica e, portanto, circunscrita em um campo reflexivo de enfrentamento e de aproximação com a experiência histórica e científica. Entendida como filosófica, a Estética "não pode interpretar a arte, sem interpretar-se de acordo com os pressupostos que lhe fornece o todo da cultura de que faz parte”. (NUNES, 1993, p.60)

Nesse sentido, o caminho que Nunes tem privilegiado é o do grupo hermenêutico do pensamento contemporâneo, erigido por Heidegger e acrescido por Hans George Gadamer e Paul Ricoeur.

Por conseguinte, o cenário estético e crítico que ora esboço, ainda que não seja um recontar histórico stricto-sensu, delineia-se em torno desses autores, ou, mais particularmente, de Heidegger, cuja estética alargou a perspectiva a respeito da metafísica ocidental e da história do Ser.

Aliás, como explica Benedito Nunes (1975a, p.211), o questionamento da Estética, como lugar circunscrito ao saber ocidental,

é hoje um questionamento essencial paralelamente ao da própria Metafísica. Questionar a estética é de fato questionar a primazia gnoseológica do sujeito implantado com o moderno regime do saber, sob a vigência do cogito cartesiano. Seria também questionar os conceitos fundamentais e correlatos de matéria, forma, eidos, substância, e até mesmo o de tekne. (grifos do autor) 
Para o professor paraense, em uma noção mais ampla, o pensamento estético compreende duas espécies. A primeira, a Estética, é definida como um domínio discursivo, por excelência especulativo, que pesquisa o fenômeno da arte em suas implicações gerais, cuja autonomia "não é outra senão a da própria indagação filosófica, levando para essa esfera o teor problematizante da reflexividade que a caracteriza”. (NUNES, 1978, p.85)

A segunda, a Crítica, é um discurso hermenêutico e analítico, que interpreta as produções artísticas em particular. Sua prática é legitimada por métodos que utiliza, exigidos que são pelo caráter contingente das obras.

Como complementa Cesare Segre (1974, p.45-6), o estudioso da Estética é capaz de escalar livremente a Torre de Babel da Arte; já o crítico se vê forçado a reconstruir, pedaço por pedaço, o complexo fenômeno artístico.

Segundo Nunes, os dois discursos se integram: o crítico ao buscar fundamentos no discurso da Estética e este ao utilizá-lo como meio de especulação teórica. O primeiro adentra o campo da Estética quando generaliza sobre o Belo ou a natureza da Arte; ao passo que o Filósofo da Arte, ao considerar as propriedades singulares de uma obra, torna-se crítico.

Essa inter-relação acontece "sem prejuízo do alcance excedentário da Filosofia”, do qual a Estética é uma extensão. Ao assentar o foco reflexivo sobre o fenômeno artístico, a Filosofia “desata, em função dele, a cadeia das questões gnosiológicas e ontológicas fundamentais”. (NUNES, 1978, p.86)

É a partir da Época Moderna que a arte passa a ser, de fato, compreendida esteticamente. Não que, antes, não houvesse uma reflexão filosófica das formas artísticas. Como sabemos, foram os filósofos gregos os primeiros a pensar a importância da arte em geral e da poesia em particular.

Platão (427-347 a.C.) converteu em discussão filosófica a sua existência e a pensou como função e finalidade. No primeiro caso, atribuiu-lhe uma dimensão social; no segundo, uma direção política. Se não foi um teórico e nem um crítico da arte, pode-se dizer, por outro lado, que os seus Diálogos foram representativos do que de melhor se produziu como pólo dramático ${ }^{15}$.

\footnotetext{
${ }^{15}$ Vattimo vai comentar, na perspectiva dessa questão, a exposição de Richard Rorty a respeito das tensões que envolvem a escrita de feição filosófica e ficcional. Cf. VATTIMO, Gianni. A filosofia e o declínio no Ocidente. In: MARTINS, Francisco M. e SILVA, Juremir Machado da (orgs.). Para navegar no século 21: tecnologias do imaginário e cibercultura. Porto Alegre: Sulina/Edipucrs, 2000, p.55-70.
} 
O Belo, o bem, a verdade, a perfeição, para o filósofo da República, pertence ao mundo das idéias; portanto, não é responsabilidade do juízo humano responder o que é belo ou não, já que este vive no mundo sensível, imitativo de um ideal concebido no mundo das idéias.

Já com a Poética, de Aristóteles (384-322 a.C.), idéias e conceitos a respeito da Poesia e dos gêneros literários foram sistematizados pela primeira vez. Diferente de Platão, o Estagirita reviu o conceito de mímesis platônica, que a concebeu como imitação do efeito de verdade, e lhe conferiu um significado outro: a "verdade" deveria ser a da obra; por isso, para que ocorresse a mímesis ${ }^{16}$, era preciso a existência de leis (totalidade, universalidade, necessidade, verossimilhança e beleza), que se uniriam para que a obra não perdesse seu caráter de unidade e completude (noção de estrutura). Em Aristóteles, ao contrário de Platão, a arte se desvinculou da filosofia, pois era vista como construção, conhecimento e possuidora de objeto próprio ${ }^{17}$. Assim, a arte, como criação humana, só pode ser bela se qualidades como proposição, simetria e ordenação forem respeitadas.

Em poucas palavras: o fato é, pois, que tanto Platão quanto Aristóteles, ainda que com visões diferentes, estabeleceram relações do Belo (Kalós) sensível com o que na arte deleita os sentidos e é merecedor de contemplação.

Entretanto, na Antigüidade, o Belo não se enquadrou no campo artístico e, no Medievo, pertenceu especialmente ao aparato divino. Anterior a Plotino (204-270 d.C.), que influenciou os primeiros pensadores cristãos - como Santo Agostinho -, basicamente nada se acrescentara à importância da Poética. A exceção, talvez, como aponta Nunes (1989, p.9), da Arte poética ou Epístola aos Pisões, de Horácio (65 a.C. - 8 a.C.), e o Tratado sobre o sublime, imputado a Longino (século I a.C.).

No decorrer do século XVIII, a arte tornou-se efetivamente um objeto de maior investigação analítica. Além da vertente do Iluminismo francês, com Rousseau (1712-1778) e

\footnotetext{
${ }^{16}$ É preciso assinalar que o conceito de mímesis foi repensado por, entre outros, Paul Ricoeur e Luiz Costa Lima. O primeiro especialmente em Temps et récit. 3 vols. Paris: Éditions du Seuil, 1985. O segundo basicamente fez desse tema sua reflexão teórica, mas pode-se conferir, por exemplo, em Mímesis e modernidade - formas das sombras. $2^{a}$ ed. São Paulo: Paz e Terra, 2003 (com prefácio de Benedito Nunes) e Mímesis: desafio ao pensamento. Rio de Janeiro: Civilização Brasileira, 2000. Também é importante enfatizar que esse assunto teve relevância na reflexão crítica de Adorno e Benjamin. Como indicação modelar e bibliográfica, destaca-se GAGNEBIN, Jeanne Marie. Do conceito de mímesis no pensamento de Adorno e Benjamin. In: Sete aulas sobre linguagem, memória e história. Rio de Janeiro: Imago, 1997, p.81-106.

${ }^{17}$ Vale comentar que Eco retoma essa idéia para rebatê-la: "se, portanto, a obra de arte se reduz a um suporte de conhecimento, em que é que o modo de proceder da arte difere do da ciência ou da filosofia?” Cf. ECO, Umberto. A definição da arte. Trad. José Mendes Ferreira. Rio de Janeiro/Lisboa: Elfos/Edições 70, 1995, p.253.
} 
Diderot (1713-1784) ${ }^{18}$, na corrente germânica (Aufklärung) despontaram autores tais como Lessing (1729-1781) e Kant (1724-1804). Nesse momento, nasceu a Estética ${ }^{19}$ (do grego aisthesis = sensível, sensibilidade) como disciplina filosófica, com o intuito de estudar o Belo e as suas manifestações na Arte. Sua inovação foi a de contribuir para oferecer a esse estudo um papel mais definido, já esboçado por pensadores anteriores. O termo foi criado por Alexander Gottlieb Baumgarten (1714-1762), que publicou, em 1750, a Aesthetica sive theoria liberalium artium (Estética ou teoria das Artes Liberais). Todavia, encontra-se ainda, neste autor, uma concepção da "verdade estética, com todos os exemplos que ele aduz, tirados da literatura clássica (...) [como] uma extensão da verossimilhança aristotélica ao conhecimento sensível.” (NUNES, 1999, p.33)

Somente com Immanuel Kant, na Crítica da faculdade do juízo (1790), iniciou-se um processo de consolidação da Estética, em que se vislumbrou uma analítica do belo ${ }^{20}$ e uma nova dimensão entre Arte e Realidade. Sem dúvida, o filósofo de Königsberg foi a personalidade emblemática desse período, cuja obra revestiu-se de uma importância ímpar para o pensamento ulterior.

Sob a égide da crítica, a filosofia kantiana pode ser compendiada em três volumes fundamentais: Crítica da razão pura (1781), em que analisa o problema do conhecimento a partir de princípios a priori; Crítica da razão prática (1788), na qual examina os preceitos morais, já iniciados em 1784 com Fundamentação da metafísica dos costumes; e Crítica da faculdade do juízo (1790), dividida em duas partes ${ }^{21}$ : “Crítica da faculdade de juízo estética”, em que investiga a analítica do belo, do sublime e introduz a idéia de gênio, e "Crítica da faculdade de juízo teleológica”, entendida como "a faculdade de ajuizar a conformidade a fins real (objetiva) da natureza mediante o entendimento e a razão”. (KANT, 2005, p.37)

\footnotetext{
${ }^{18}$ Com relação a esse assunto, é interessante verificar COSTA LIMA, Luiz. O fingidor e o censor: no Ancien Régime, no Iluminismo e hoje. Rio de Janeiro: Forense Universitária, 1988.

${ }_{19}$ Nunes (1999, p.31) lembra que, para Heidegger, a ascensão da Estética é "uma das características fundamentais da época moderna".

${ }^{20}$ Nessa analítica, os juízos do gosto são expostos por meio de quatro categorias: da qualidade; da quantidade; da finalidade; e do modo. Cf. Primeiro Livro, da Primeira parte: "Crítica da faculdade de juízo estética”. In: KANT, I. Crítica da faculdade do juízo. $2^{\mathrm{a}}$ ed. Trad. Valério Rohden e António Marques. Rio de Janeiro: Forense Universitária, 2005, p. 47-89.

${ }^{21}$ Na resenha "As duas Introduções à Crítica do juízo", de livro homônimo (KANT, I. Duas Introduções à Crítica do juízo. São Paulo: Iluminuras, 1995; nota preliminar e apresentação de Ricardo Terra), Benedito Nunes (1998, p.187-193) comenta que a prioridade dada à primeira parte da $3^{\mathrm{a}}$ Crítica é justificada por "mais de um motivo relevante"; entre eles, o desempenho da "Analítica do belo", para o pensamento estético moderno, e a prerrogativa concedida ao juízo estético, já que "falta ao juízo teleológico a pureza de fundamento do juízo estético, a que o sentimento do prazer, munindo-o do sinal de um possível acordo com a ordem natural, confere um estatuto prioritário". (p.191) Por outro lado, Costa Lima (2000, p.51-3), na defesa da integração entre as partes, baseado em tese de John Zammito no contraponto a Lyotard, vai mostrar que a importância dada à divisão da experiência estética estimula impasses quanto às diferentes teorias movidas contra a mímesis da arte.
} 
Como explica Nunes (1998, p.98), não é a Kant que se deve "nem o regime normativo da Estética nem a sua dominância sobre a compreensão e a prática da arte”. Contudo, da sua filosofia surgiu um repensar da obra artística, cuja influência se fez sentir, por exemplo, nos românticos Schlegel (1767-1845), Novalis (1772-1801), Schelling (1775-1854), na questão do gênio artístico $^{22}$, e nos idealistas Fichte (1762-1814) e Hegel (1770-1831) ${ }^{23}$. Dentre os neokantianos ${ }^{24}$, destaca-se Ernst Cassirer (1874-1945), cujo livro Filosofia das formas simbólicas (1923) ${ }^{25}$ contribuiu, segundo Benedito Nunes (1993, p.195), para diminuir a distância entre Filosofia e Literatura.

Na transição do século XVIII para o XIX, por "espelhamento na palavra 'crítica', então tornada preferencial - crítica dos sentimentos, crítica da experiência, crítica da razão -” (NUNES, 1999a, p.13), chega-se à designação crítica literária, já que, neste momento, conforme Michel Foucault em Les mots et les choses (1966), a "literatura” propriamente dita teria se configurado.

A expressão “crítica literária”, por sua vez, comporta uma série de problemas, uma vez que, sob esta denominação, supõe-se a existência de um conceito de literatura fundamentado por valores estéticos compartilhados e por um cânone de referência, os quais, atualmente (ou talvez desde sempre), não são consensuais ${ }^{26}$. Da mesma forma, esse termo traz à baila, com certa suspeita, a atividade do crítico.

De fato, desde as suas manifestações precursoras, o papel e a função do crítico têm sido postos em discussão:

O crítico literário sempre foi um agregado e um dependente, sempre precisou do apoio do escritor-criador para existir. As metáforas usadas pelos críticos para definir

\footnotetext{
${ }^{22}$ Para Kant (2005, p.153), “Gênio é o talento (dom natural) que dá a regra à arte. Já que o próprio talento enquanto faculdade produtiva inata do artista pertence à natureza, também se poderia expressar assim: Gênio é a inata disposição de ânimo (ingenium) pela qual a natureza dá a regra à arte”. Para os românticos, o gênio é transformado na competência de conhecimento específico da arte, por antagonismo à ciência, e sua concepção apoiou a passagem da produção artística do campo da mimesis para o da criação.

${ }^{23}$ Lucchesi (2005, p.60), inclusive, aponta que, ainda de forma indireta, Kant influencia Hegel no direcionamento da relação entre arte e público, desenvolvida na parte final do primeiro volume da Estética (1832). Da mesma forma, pode-se dizer que Kant e Hegel abriram caminho para o desenvolvimento da Estética da Recepção de Jauss e Iser. Cf. LUCCHESI, Ivo. Walter Benjamin e as questões da arte sob o olhar da hipermodernidade. In: Revista Comum. Rio de Janeiro, vol.11, n 25, dezembro de 2005, p.57 a 91.

${ }_{24}^{24}$ Cf. NUNES, Benedito. Kant reinterpretado. In: Filosofia Contemporânea - Edição revista e atualizada. Belém: EDUFPA, 2004, p.22-7.

${ }^{25}$ Para Nunes (2004, p.26), essa obra “monumental” trouxe de inédito o alargamento do "domínio da experiência possível estruturada pelo pensamento, nele abrangendo, ao lado da ciência, a linguagem, o mito e a arte" e a compreensão da "atividade estruturadora do pensamento como decorrência da função simbólica, primordial ao espírito humano, que já se exerce, antes de alcançarmos o grau de abstração necessária ao conhecimento objetivo, na produção de formas lingüísticas, religiosas e artísticas”.

${ }^{26}$ A respeito da questão do cânone literário e das mudanças pelas quais passou a crítica na atualidade Cf. PERRONE-MOISÉS, Leyla. Que fim levou a crítica literária? In: Inútil poesia. São Paulo: Companhia das Letras, 2000, p.335-344.
} 
sua condição revelam esse sentimento de incompletude, de mutilação: para SainteBeuve, o crítico é o impotente; para Georges Poulet, o cego; para Roland Barthes, o afásico do eu, o escritor em sursis. (PERRONE-MOISÉS, 1973, p.15)

Neste sentido, a indagação acerca do propósito da tarefa crítica literária, ou de como esta excede a divisa da subjetividade, é dependente de um impasse maior encontrado em Kant: qual a certeza de se conhecer algo?

Para o filósofo alemão, a faculdade do conhecimento, de conhecer a priori coisas, é diferenciada entre a faculdade do entendimento, que se efetua com princípios a priori de conhecimentos essenciais, teóricos, e as faculdades da razão e do juízo, termo intermediário entre o entendimento e a razão, ligado ao sentimento de prazer e desprazer. Na faculdade do entendimento, os juízos são determinantes ${ }^{27}$, isto é, esclarecem o modo de agir dos objetos a que visam; nas faculdades da razão e do juízo, os juízos são reguladores, porque conduzem nossos comportamentos. Há, portanto, uma relação inseparável entre elas: todos os conceitos estabelecidos pelo entendimento se manifestam sob a forma de um juízo.

Desse modo, torna-se imperioso o estudo da especificidade da faculdade do juízo, que, intrínseca à atualização do entendimento, é desprovida de sua certeza objetiva:

Uma Crítica da razão pura, isto é, de nossa faculdade de julgar segundo princípios a
priori, estaria incompleta se a faculdade do juízo, que por si enquanto faculdade do
conhecimento também a reivindica, não fosse tratada como uma sua parte especial.
(...) Então a crítica tem que ter investigado antes o solo para este edifício tão
profundamente quanto jaz a primeira base da faculdade de princípios independentes
da experiência, para que não se afunde em parte alguma, o que inevitavelmente
acarretaria o desabamento do todo. (KANT, 2005, p.12-3)

Na Crítica da faculdade do juízo $\left(2005^{28}\right)$, Kant expõe acerca desta como a faculdade de “pensar o particular como contido no universal”. (p.23) A essa sentença, chamada de subsunção, os juízos apresentam-se de duas maneiras: o determinante e o reflexionante, que se subdivide, por sua vez, em estéticos e teleológicos.

São juízos opostos, porque, no determinante, o universal (a regra, a lei) é dado e nele subsume o particular; no reflexionante, o particular é dado, e deve-se descobrir o universal. Por isso, ele necessita pensar para si mesmo uma lei que lhe possibilite encontrar um universal sob o qual há de subsumir seu objeto:

\footnotetext{
${ }^{27}$ A faculdade de juízo determinante é regida por leis transcendentais, isto é, pelo conhecimento do a priori das coisas.

${ }^{28}$ A edição consultada refere-se à traduzida por Valerio Rohden e António Marquez. $2^{\mathrm{a}}$ ed. Rio de Janeiro: Forense Universitária, 2005.
} 
(...) só a faculdade de juízo reflexiva pode dar a si mesma um tal princípio como lei e não retirá-lo de outro lugar (porque então seria faculdade de juízo determinante), nem prescrevê-lo à natureza, porque a reflexão sobre as leis da natureza orienta-se em função desta, enquanto a natureza não se orienta em função das condições, segundo as quais nós pretendemos adquirir um conceito seu, completamente contingente no que lhe diz respeito. (KANT, 2005, p.24)

A crítica, como é de sua origem etimológica (krínein) já referida, supõe julgamento. Assim, o juízo próprio da crítica é o reflexivo e não o determinante; isto é, "não um regulador da conduta, mas algo que leva a mente a curvar-se” (COSTA LIMA, 2000, p.16) sobre o que ela própria sente. Falta-lhe, portanto, o fundamento da certeza, pois o juízo estético, pertencente ao reflexivo, não é o juízo de conhecimento (objetivo), mas um juízo assentado em uma base subjetiva, que demonstra o prazer que sentimos perante uma obra e a afirmação de sua beleza.

Ao contemplar o belo, o sujeito não se ampara no cognitivo, mas em alguma característica mínima do objeto que se manifesta em decorrência da atenção que se deu a ele. O sujeito, porém, é livre para se interessar ou não pela existência do objeto ${ }^{29}$, fato que designa como complacência: "Não se tem que simpatizar minimamente com a existência da coisa, mas ser a esse respeito completamente indiferente para em matéria de gosto desempenhar o papel de juiz”. (KANT, 2005, p.50)

O juízo do gosto, assim, recai em um sentimento que se anuncia sob a forma de um jogo livre da imaginação. (Cf. Kant, 2005, p.62) Por resultado, ele não é lógico, mas estético: seu princípio não pode ser senão subjetivo.

No § 35, na analítica do sublime (p.133), Kant assinala, no entanto, que o juízo do gosto é parecido com o lógico "no fato de que ele afirma uma universalidade e necessidade, mas não segundo conceitos do objeto, conseqüentemente apenas subjetiva”. Mais adiante declara: “gênio é o talento (dom natural) que dá a regra à arte”. (p.153)

Conforme Nunes (2000, p.52), a crítica, como “avaliação, interpretação e descrição, recai, de qualquer forma, na órbita do juízo de gosto, porquanto a literatura, lida como literatura, já se inclui no domínio da arte (...) e se acha afetada pelo índice estético do 'belo’”. É dessa forma que a literatura introduz-se na experiência individual do crítico, experiência

\footnotetext{
${ }^{29}$ Para Martin Seel, essa liberdade nos possibilita "experimentar a determinação de nós mesmos no mundo". Cf. SEEL, Martin. "A libertação da estética filosófica por Kant” (artigo inédito). Trad. Alfred Keller. Goethe Institut, 2004.
} 
esta que é também social e histórica, mediada e transformada pela leitura, como possibilidade de aproximação ou de percepção da obra.

Porém, como já comentado, há de se ter claro que nem sempre a prática da crítica e a figura do crítico, como profissional, ocorreram sem maiores abalos.

No Romantismo alemão, se questionava como este poderia julgar sem passar pelo juízo estético e, ao ser isso possível, “deveria ele pôr-se à altura do gênio e, como o gênio, dar regras à arte, caso em que seria um 'autor em segunda potência””. (NUNES, 2000, p.53) Se apenas o autor teria condições de julgar a obra criada, então, o poeta seria poeta como criador e também crítico como poeta. Pela primeira vez, assim, essas duas vertentes se vinculariam e surgiriam o poeta-crítico ou crítico-poeta.

Também no período romântico se uniriam a Poesia e a Filosofia, posto que autores como Friedrich Schlegel $^{30}$ e Novalis, por influência de Fichte ${ }^{31}$, defendiam a presença de uma intuição intelectual $^{32}$, com habilidade de criar o objeto no momento de conhecê-lo. A Filosofia era vista como arte e poesia; arte e poesia eram idênticas à Filosofia ${ }^{33}$.

Sob este aspecto, Benjamin (1993) vai mostrar que, tanto a arte quanto a filosofia resultariam de um elemento reflexivo comum, posto que a reflexividade, o voltar-se da consciência sobre si mesma, é o componente causador da intuição intelectual.

Ainda é com o autor de $O$ conceito de crítica de arte no romantismo alemão (1993), que encontramos a assertiva acerca da importância da estética kantiana como pressuposição principal da crítica da arte romântica. Não obstante, o crítico de arte, no contexto da filosofia crítica de Kant, nos fins do século XVIII, chamava-se juiz da arte (Kunstrichter): aquele que julgava as obras artísticas baseado em leis, normas.

Por certo, a crítica deste período estava mais interessada em estabelecer valores para os textos, na tentativa de homogeneizar o gosto burguês. Isto é, caberia ao juiz da arte, cujo caráter era mais pragmático do que investigativo, tão-só legitimar os princípios da burguesia,

\footnotetext{
${ }^{30}$ A respeito desse autor vale Cf. COSTA LIMA, Luiz. Limites da voz: Montaigne, Schlegel e Kafka. 2 vols. Rio de Janeiro: Rocco, 1993.

${ }^{31}$ Cabe apontar que os românticos ora seguiram Fichte, ora do pensamento dele se afastaram. Cf. BENJAMIN, Walter. O conceito de crítica da arte no romantismo alemão. Trad. Márcio Seligmann-Silva. São Paulo: Iluminuras, 1993, p.30-5.

${ }^{32}$ Em Kant, a intuição intelectual pressupõe a habilidade de compreender e de expor um objeto de maneira imediata, ou seja, sem mediação sensível. Em Fichte, esta elocução refere-se à ação do Eu de pôr a si próprio como princípio primeiro da filosofia transcendental. Os românticos, no entanto, deslocaram a intuição fichtiana do plano prático, para o plano teórico. Cf. BENJAMIN, Walter. op. cit., p.42.

${ }^{33}$ Gerd Bornheim lembra que, para Schlegel, além da arte e da filosofia, também a religião e a moral deveriam ser integradas: "filosofia, arte, moral e religião devem constituir um todo único". Cf. BORNHEIM, Gerd. Filosofia do romantismo. In: GUINSBURG, J. (org.). O Romantismo. São Paulo: Ed. Perspectiva, 1985, p.94.
} 
classe em ascensão, por meio de opiniões expressas nas colunas dos jornais e das revistas que despontavam no período ${ }^{34}$.

É somente com os românticos que surgiu o termo crítico da arte (Kritiker), aquele que questionava como a razão pode esclarecer uma obra vista como produto de um gênio criador, isto é, um produto individualizado, que, portanto, só pode ser julgado com base no seu próprio fim.

Se, em Kant, a arte era concebida como “objeto” para a prática da crítica - “Não há uma ciência do belo, mas somente crítica, nem uma ciência bela, mas somente arte bela” (KANT, 2005, p.150) -, no romantismo, com Hegel, a arte é vista como produto da História, por meio da qual o Belo se efetua e manifesta a "verdade”: "O objetivo final da arte não pode ser senão o de revelar a verdade”. (HEGEL, 1969, p.83)

Cabe lembrar que as reflexões filosóficas de Hegel abarcaram diferentes temas do conhecimento e são referências, mesmo quando é objeto de refutação, em grandes pensadores do século XIX e XX. Por um lado, há autores que seguiram seus passos, como Bauer (18091882). De outro, pode-se citar aqueles que se rebelaram contra seu idealismo, como Feuerbach (1804-1872), e outros, como Karl Marx (1818-1883), que demoliram, pela crítica, o idealismo do sistema, mas incorporaram o seu método, a dialética.

Já Nicolai Hartmann (1882-1950) e Benedetto Croce (1866-1952) ${ }^{35}$ abstraíram o método dialético, porém aceitaram o caráter histórico da realidade e as formas do espírito objetivo.

No campo da estética, seus pressupostos renderam, também, significante repercussão nos estudos literários. Basta assinalar, por exemplo, a presença da leitura hegeliana em Adorno (1903-1969), que renova e reavalia as idéias de Hegel em trabalhos como Teoria estética (1982) e Negative dialectics (1983) ${ }^{36}$.

Como esclarece Nunes (2004, p.27) a respeito da importância histórica da filosofia hegeliana:

Foi Hegel quem colocou em primeiro plano, no séc. XIX, a idéia de evolução da Natureza e do Espírito, quem definiu o caráter histórico do pensamento, da filosofia

\footnotetext{
${ }^{34}$ A respeito da ascensão da burguesia e da crítica, do crítico e do público neste período Cf. HABERMAS, Jürgen. Mudança estrutural da esfera pública: investigações quanto a uma categoria da sociedade burguesa. Trad. Flávio R. Kothe. Rio de Janeiro: Tempo Brasileiro, 1984, p.46-59.

${ }^{35}$ Desse autor vale Cf. CROCE, B. O que é vivo e o que é morto na filosofia de Hegel. Trad. Vittorino Nemésio. Portugal/Coimbra: Imprensa da Universidade, 1933.

${ }^{36}$ Cf. ADORNO, Theodor. Teoria estética. Trad. Arthur Mourão. São Paulo: Martins Fontes, 1982; e Negative dialectics. New York: The Continuum Publishing Company, 1983.
} 
e da cultura, e quem mostrou existir, em cada época, uma conexão orgânica, que varia conforme mudam as condições do desenvolvimento humano, entre a arte, a religião e as ciências. Foi Hegel, finalmente o crítico da concepção romântica do mundo e o reformulador da dialética, à qual atribuiu a importância de método integral da filosofia.

Embora a Estética $(1993)^{37}$ seja considerada a obra em que a reflexão filosófica se une a uma história da arte, muitas idéias desta vieram da Fenomenologia do Espírito (2002), em que a leitura da tragédia Antígona, de Sófocles, marca o andamento dialético que induz da certeza sensível à consciência e à consciência de si.

No texto “A morte da arte em Hegel” (1993a), Benedito Nunes resume de tal forma a doutrina hegeliana a respeito da natureza da arte que seria, aqui, excessivo recontar. Contudo, faz-se necessário destacar alguns pontos, já que Hegel, ao proferir uma sentença sobre o fim da $\operatorname{arte}^{38}$, acabou por fazer uma ponderação não apenas histórica, mas com uma qualidade de filosofia da história ${ }^{39}$.

A arte, a religião e a filosofia pertencem, para o pensador alemão, ao domínio do Espírito Absoluto. O Absoluto, na Arte, é alcançado pela “intuição sensível” e apreendido pelo sentimento. A Beleza de que ela se constitui, fruto do Espírito, já estabelece a aparição sensível da Idéia. Na atividade artística, tudo é Espírito: a Verdade se desvenda de forma concreta, como se se encontrasse na superfície dos objetos, junto à matéria, à representação, e presentificada nos “elementos sensíveis que lhe dão corpo”. O Absoluto torna-se aparência e manifesta-se em uma linha escassa para o pensamento conceptual. Para Hegel, a aparência “deve ser interpretada mais de acordo com Plotino do que com Platão: é a forma exterior de um conteúdo interno, tão verdadeiro quantos aqueles que a razão apreende abstratamente e que na obra de arte aparece concretamente individualizado”. (NUNES, 1989, p.65)

A Arte se realiza em formas individuais, análogas às formas sensíveis e exteriores da Natureza, e que compõem o Ideal, ou seja, a Idéia ou a Beleza manifestada na Arte. No desenvolvimento histórico da evolução do Espírito, passa-se por três momentos de expressão artística - simbólica, clássica e romântica - conforme o "específico teor do sensível que a

\footnotetext{
${ }^{37}$ Dos muitos textos produzidos a respeito da Estética, de Hegel, vale consultar BORNHEIM, Gerd. O que está vivo e o que está morto na Estética de Hegel. In: NOVAIS, Adauto (org.). Artepensamento. São Paulo: Companhia das Letras, 1994.

${ }^{38}$ Quanto a esse tema e as diferentes interpretações a respeito Cf. BUNGAY, Stephen. Beauty and truth. A study of Hegel's Aesthetics. Oxford: Oxford University Press, 1987.

${ }^{39}$ Acerca desta questão Cf. STEIN, Ernildo. A destruição da Estética como conseqüência da destruição da metafísica. In: DUARTE, Rodrigo A. P. (org.). Anais do colóquio nacional A morte da arte hoje. Belo Horizonte: Laboratório de Estética/FAFICH-UFMG,1993, p.34-45.
} 
vincula a uma das artes singulares (einzelnen) - plástica (bildend), sonora (tonnend) e verbal (rendende Kunst), cada qual também se desenvolvendo numa linha (que lhe é própria)”. (NUNES, 1993a, p.18)

Essas expressões artísticas são formas de concepção-do-mundo e se referem a determinadas culturas ou períodos históricos. Na simbólica, há um predomínio do religioso, do sagrado, típico das culturas do Oriente. Na clássica, há a harmonia do individual e do geral, da natureza e do espírito, do humano e do divino, característico da noção grega do mundo. Por fim, na expressão romântica, há a interiorização da beleza sensível e a valorização da espiritualidade; o artista busca dentro de si a realidade; a subjetividade, portanto, assume importância capital.

Para Hegel, as diferentes artes (como a arquitetura, escultura, pintura, música, poesia) se relacionam com as concepções-do-mundo que representam. A arquitetura é peculiar à fase simbólica; a escultura, ao ideal clássico. A carga de espiritualidade fundamental à expressão romântica inicia-se na pintura; alcança sua forma típica na música e esgota as suas probabilidades na poesia, síntese de todas as artes.

\begin{abstract}
Da arquitetura, na fase simbólica, à poesia, culminância da expressão romântica, estende-se a caminhada do espírito que, de forma em forma, de arte em arte, vai consumindo a matéria sensível, até exauri-la totalmente. Na Poesia, primeira e última das artes, por ser a mais elevada e a mais completa, o pensamento serve-se das palavras, convertendo-as em veículos da Idéia triunfante. Ela fecha o sistema evolutivo da expressão artística, superando qualitativamente a Arquitetura, a Escultura, a Pintura e a Música. Mas, com ela, encerra-se a função da própria Arte no desenvolvimento gradual do Espírito. (NUNES, 1989, p.105-6)
\end{abstract}

Desse modo, o subjetivismo romântico passa a ser a última fase do desenvolvimento artístico. Segundo Hegel (1996, p.43-4), as condições do tempo presente não são benéficas à arte. Tanto o artista quanto a cultura são prejudicadas pelas reflexões que se alastram em volta delas. Ao perder tudo de autenticamente verdadeiro e vivo, a arte passa a ser "coisa do passado".

Essa crise da criação artística, promulgada por Hegel, vai ser atualizada e comentada por Heidegger, por exemplo, em A origem da obra de arte (1977).

\title{
II.1.2. Heidegger e a Destruição da Estética
}


É notória a presença de Heidegger no discurso de Benedito Nunes ${ }^{40}$. Acompanhar as discussões que o professor paraense promove a respeito da Estética e da Arte é, portanto, seguir os passos das reflexões heideggerianas.

Tais reflexões do filósofo alemão abarcam temas como a arte clássica dos gregos, as artes plásticas contemporâneas e, na literatura, uma especial atenção a obras de poetas como Hölderlin, Rilke, S. George e Trakl, já anteriormente referidos, juntamente com a hermenêutica heideggeriana, no primeiro capítulo ${ }^{41}$. Heidegger localiza a Estética e a Arte em um contexto da História do Ser em cuja discussão aparece a superação da metafísica e a destruição da Estética.

A tarefa da "superação da metafísica" no pensamento de Heidegger tem uma raiz nietzcheneana advinda de conceitos como a morte de Deus, o desaparecimento do suprasensível e a transvaloração de todos os valores. Superar significa repensar e questionar toda a tradição metafísica, a noção de ciência e de verdade. Desse modo, a “destruição da metafísica” abriga dois diferentes pesos conceituais: um aponta para o trabalho de “construção de um aparato conceitual novo"; outro, remete a um "horizonte em que a metafísica é colocada no contexto de uma história que tem, de um lado, um certo caráter ontológico e, de outro lado, é produto de uma espécie de destino do esquecimento do ser”. (STEIN, 1993, p.35)

A expressão “destruição da Estética” comparece nesse contexto: o fim da arte é decorrência do fim da metafísica e do vínculo arte e técnica como uma crise da arte. Nesse sentido comparece o veredicto de Hegel sobre a morte da arte que Heidegger retoma no posfácio da conferência, de 1936, A Origem da obra de arte:

(...) A decisão final acerca do veredicto de Hegel ainda não foi proferida; com efeito,
por detrás deste veredicto acha-se o pensamento ocidental desde os gregos,
pensamento que corresponde a uma já acontecida verdade do ente. A decisão acerca
do veredicto de Hegel será proferida, se o chegar a ser, a partir da própria verdade
do ente e a propósito dela. Mas até lá, o veredicto de Hegel permanece válido. Só
por isso é que é necessária a pergunta sobre se a verdade, que o veredicto enuncia,
será definitiva, e o que se passa, se assim for. (HEIDEGGER, 1992, p.66)

Aliás, Nunes (1993a, p.30) aponta que não é de se estranhar que, na mesma época, surja a exposição de Walter Benjamin, A obra de arte no tempo de sua reprodutibilidade técnica, provinda do “mesmo desencantamento, entrevista a irrupção, embora vaga, nas

\footnotetext{
${ }^{40}$ Irei retomar esse assunto no item II.3 (As raízes filosóficas: marcas do discurso teórico-crítico), p.152.

${ }^{41}$ Cf. item I.4.1 (Breves interfaces do pensamento hermenêutico), p.78-81.
} 
Preleções [de Hegel], da diferença entre valor cultural (kultwert) e valor de exposição (Austellungswert)".

Não cabe, aqui, detalhar a palestra heideggeriana. Basta lembrar que sua importância é fundamental, pois abriu uma discussão sobre os destinos da arte e uma reflexão acerca da questão da técnica. Após este texto, Heidegger irá se dedicar a outros ensaios com o mesmo teor e deixará sua marca em conceitos como os de

\footnotetext{
mundo e de quaternidade que ressoam na jarra ( $k r u g$ ) do ensaio A coisa (Das Ding), nas pontes (Brücken) e na casa camponesa da Floresta Negra na conferência Construir, morar, pensar (Bauen, Wahnen, Denken). E quem se esquecerá dos Sapatos da camponesa de Van Gogh descritos em Da origem da obra de arte? (STEIN, 1993, p.45)
}

A rigor, como esclarece o professor paraense, não há uma estética heideggeriana senão como "suspeita da Estética, enquanto análise da experiência do belo. Afiançar a origem da arte significa, do ponto de vista do filósofo de Ser e Tempo, fazer da arte uma origem: emergência coextensiva do ser e da linguagem”. (NUNES, 1978, p.133) Esta suspeita da Estética era conseqüência de uma reviravolta da filosofia, a demandar "revisão simultânea da idéia de arte do conceito de homem”.

Benedito Nunes dialoga com os escritos heideggerianos, principalmente, naqueles em que a arte é refletida na confrontação da filosofia com a poesia. Esse tema, no entanto, será discutido mais adiante.

\section{II.1.3. A leitura crítica}

Como comentado anteriormente, para os românticos, segundo Benjamin (1993, p.74), “a crítica é muito menos o julgamento de uma obra do que o método de seu acabamento. Neste sentido, eles fomentaram a crítica poética [e] superaram a diferença entre a crítica e a poesia...” (BENJAMIN, 1993, p.77)

Todavia, no decorrer do século XIX, a crítica, sob a égide dos rodapés dos jornais, das revistas especializadas e das análises universitárias, viveu certo descompasso entre as produções que vigoravam na época e os preceitos que lhe cabia divulgar. Sainte-Beuve, por exemplo, praticamente ignorava obras como as de Flaubert, de Balzac, de Baudelaire. 
Se se deve a Proust, em Contre Sainte-Beuve, as réplicas das críticas do autor das Causeries $d u$ Lundi, o próprio escritor de À la recherche du temps perdu ${ }^{42}$ teria sido rejeitado na editora Gallimard pelo romancista André Gide que, só mais tarde, reconheceria seu erro ${ }^{43}$.

Assim, ao lado de uma linha de pesquisa crítica historicista ou biográfico-psicológica, o final do século XIX e início do XX viriam a florescer também um impressionismo crítico, cuja atitude era a da fruição da leitura e dos juízos de gostos pessoais.

No entanto, nesse momento também despontava uma reação contra o afastamento entre produção poética e julgamento acadêmico e uma rejeição aos métodos positivistas, com o desenvolvimento de novos procedimentos na análise de textos.

Nesse sentido, o destaque é, sem dúvida, para o Formalismo Russo, que realçou a função estética do poético e propôs uma nova forma de pensar a arte literária ${ }^{44}$.

De maneira sumária, pode-se dizer que a crítica do século XX

(...) além de sua modalidade difusa e reiterada de resposta às primeiras sugestões da
obra imediatamente cantadas (impressionismo), visaria o elemento estético, como a
especificidade a caracterizar o literário, ora tomado como organização poética de
significação autônoma e intransitiva (close-reading), ora à busca da forma
significante da linguagem em suas operações de construção interna (formalismo),
ora na correspondência entre a forma e os significados sociais e históricos (crítica
histórica e sociológica) - seja com apoio na Ciência da Linguagem (Estilística), seja
com apoio na Fenomenologia (crítica fenomenológica), seja com apoio na noção de
estrutura lingüística (crítica estruturalista). (NUNES, 1999a, p.15)

Desse modo, as diferentes perspectivas com relação ao poético garantem à crítica uma natureza cujo princípio é, mais do que estabelecer regras, ser entendida como um instrumento para o pensar. Mesmo sem uma postura normativa, o crítico, todavia, pode utilizar-se de conceitos. Tais conceitos, porém, são destituídos de um traço regulador do objeto:

Na crítica de arte e de literatura, o conceito se torna a ferramenta para o pensar; algo,
por definição, plástico e modificável de acordo com o objeto singular que analisa,
com sua posição no espaço e no tempo. Nesse sentido, poder-se-ia mesmo dizer que
a crítica, porque sabe que nunca está pronta para ser aplicada, apresenta tão-só o
limite a que cada crítico aspira. Não há propriamente críticos, mas sim aqueles que

${ }^{42}$ Cf. PROUST, Marcel. Contre Sainte-Beuve. Paris: Gallimard, 1971; La recherche du temps perdu. Paris : Librairie Gallimard Éditions de La Nouvelle Revue Française, 1920-1929 ; SAINTE-BEUVE. Causeries du Lundi. 3 Vol. Paris: Librairie Larousse, 1953.

43 Cf. COELHO, Marcelo. Jornalismo e crítica. In: MARTINS, Maria Helena (org.). Rumos da crítica. São Paulo: Editora SENAC/Itaú Cultural, 2000, p.83-8.

${ }^{44}$ Pelo caráter sensível com que revisita pontos importantes do Formalismo Russo, bem como atualiza a bibliografia a respeito do tema Cf. BERNARDINI, Aurora Fornoni. Formalismo Russo, uma revisitação. In: Revista Literatura e Sociedade. Departamento de Teoria Literária e Literatura Comparada/Faculdade de Filosofia, Letras e Ciências Humanas/Universidade de São Paulo - Nº 5. São Paulo: USP/FFLCH/DTLLC, 2000, p.30-42. 
se aproximam, ora mais, ora menos, do horizonte do pensar que os justifica. (COSTA LIMA, 2000, p.17)

O pensar que justifica a crítica de Benedito Nunes está no seu senso de acuidade de sua função crítica. Isto é, da sua consciência em querer ultrapassar a experiência estética suscitada pela obra.

Para ele, sob o efeito de encanto que lhe proporcionou a "suspensão", após a percepção estética, ocorre uma Katharsis, na acepção de Jauss (1979, p.81): aquela que libera o "espectador dos interesses práticos e das implicações de seu cotidiano, a fim de levá-lo, através do prazer de si no prazer do outro, para a liberdade estética de sua capacidade de julgar”.

A experiência estética a que Nunes se refere liga-se a uma dimensão ontológica; isto é, são estéticas, como a de Sartre (1905-1980) e a de Merleau-Ponty (1908-1961) ${ }^{45}$, ainda que com sensíveis diferenças, que "integram a experiência estética à estrutura da subjetividade humana, e realçam, sobretudo a de Merleau-Ponty, o papel que as obras de arte, particularmente as literárias e pictóricas, desempenham no desvendamento do real”. (NUNES, 1993, p.61)

Na citação acima, o realce da estética merleau-pontyana tem uma razão particular: é que, a partir da obra Signes (1960), o filósofo francês muda da perspectiva fenomenológica para uma investigação ontológica.

Para Merleau-Ponty, a ontologia é concebida como região pré-reflexiva, "selvagem e bruta, de onde emergem as categorias reflexivas”. A filosofia necessita regressar às origens da própria reflexão e desvendar seu solo anterior à tarefa reflexiva e responsável por ela. "Essa região é o 'logos do mundo estético’, isto é, do mundo sensível, unidade indivisa do corpo e das coisas, unidade que desconhece a ruptura reflexiva entre sujeito e objeto”. (CHAUÍ In: MERLEAU-PONTY, 1989, p.VIII) No entanto, as reflexões nascidas nessa região carregam um dinamismo e simbolismo próprios, que progridem historicamente e constituem a região do “logos do mundo cultural”, ou seja, “da prática inter-humana mediada pelo trabalho e, portanto, pelas relações sociais e pelas coisas aí produzidas”. (idem)

As idéias e conceitos que Merleau-Ponty desenvolve a respeito da dimensão ontológica da Arte e da palavra poética tem, para Nunes, um significado preciso: será um dos

\footnotetext{
${ }^{45}$ Mais adiante, no item II.3. (As raízes filosóficas: marcas do discurso teórico-crítico), p.152, esses autores serão melhor comentados.
} 
embasamentos reflexivos que ele incorpora ao seu discurso para aproximar a descrição filosófica ao dizer poético. Esta questão, contudo, será discutida mais adiante. Por ora, gostaria de assinalar que, para o autor de Le visible et l'invisible (1964), a existência da obra de arte ocorre como uma maneira de ver ou de dizer o mundo. A experiência estética que se inicia provocada por essa obra de arte, suspende a realidade, mas depois a ela faz voltar; volta essa, no entanto, já transformada pela vista e pela linguagem do mundo.

É preciso esclarecer, entretanto, que a experiência estética não ocorre apenas na recepção da obra de $\operatorname{arte}^{46}$. O autor do texto também é capaz de ir além dos limites da escritura. Ou melhor, trabalhar de tal forma a linguagem a ponto de romper com as fronteiras da sua própria exigência pessoal.

De tal ruptura da linguagem, do desconforto/tensão que ela gera, a experiência estética pode provocar uma nova visão ao crítico: ao aceitar o desafio, ele se reconhece no jogo da linguagem $^{47}$, que a obra lhe proporciona.

É somente nesse impasse que há a passagem da experiência estética para a crítica. De qual crítica? Daquela que torna presente uma nova dimensão da poíesis, que saiba distanciarse do discurso da arte, para não se confundir com ele.

A leitura do crítico seria, então, um caminho entre o ressaltar do gênero poético, sem que a sua própria escritura se transforme em poética, e um modo de pensar a respeito da obra, sem ser uma análise cientificista. Por isso, Costa Lima (2000, p.17) afirma que o crítico não tem um lugar definido.

O leitor, portanto, ao buscar as análises produzidas, procuraria saber como o crítico fundamentou sua investigação e não, simplesmente, saber o que ele compreendeu de certos textos. Desse modo, o leitor tem sua criticidade desenvolvida e pode, ocasionalmente, contrapor ou ir além do juízo do analista.

Se na leitura que Benedito Nunes empreende do poético aparece o uso de imagens ${ }^{48}$, isto não significa que sua escritura se torne poética. Há de se ter cuidado: a imagem não é

\footnotetext{
${ }^{46}$ Para uma discussão mais abrangente Cf. COSTA LIMA, Luiz. Poesia e experiência estética. In: Intervenções. São Paulo: EDUSP, 2002, p.39-54 e obra já citada na nota 26.

${ }^{47}$ A expressão "jogo da linguagem" refere-se ao termo usado por Wittgenstein nas Investigações filosóficas (1989), livro do qual se comentará mais adiante.

${ }^{48}$ No capítulo III, esta questão será retomada. A palavra "imagem" substitui, por vezes, o termo "metáfora" quando se quer destacar o seu aspecto "plástico". Cf. CARONE, Modesto. Metáfora e montagem. São Paulo: Perspectiva, 1974, p.12.
} 
característica intrínseca do poético ${ }^{49}$, assim como, definir o que é poético ou não, como vimos, depende da maneira como cada época considera e valoriza a arte ${ }^{50}$.

No passado, a estética "pré-existia à ação criadora e impunha-se a ela, ao passo que agora as inquietações estéticas são por assim dizer compostas juntamente com a elaboração da obra.” (BORNHEIM, 1993, p.54) Isto expressa que a linguagem da arte, unida à criação estética, exige do crítico profundas mudanças para que ele possa acompanhar os processos de desenvolvimento pelas quais passou a composição artística.

Acompanhar não significa romper a divisa entre a crítica e a obra de arte. Acompanhar significa, para Benedito Nunes (2005, p.305), deixar que a arte fale, não a crítica, pois “quando a Filosofia e as Ciências se calam, é sempre a poesia que diz a última palavra”.

Como crítico hermenêutico, como autor que traz no seu discurso uma relação dialogal com o modus operandi da Filosofia Hermenêutica, Nunes (1993, p.198) reconhece que deve evitar duas falácias: a primeira, "é a falácia da transposição de uma dada filosofia, aplicada, de maneira absorvente, ao entendimento do texto literário que passa a ilustrá-la”. A segunda, achar que as diversas metodologias que existem para análise dos textos literários dêem conta da leitura do objeto literário:

Lingüística, Sociologia, História, Psicologia ou Psicanálise - qualquer desses campos metodológicos pode ser requerido para a compreensão da obra, e nenhum deles, por mais que necessário seja, é suficiente no cumprimento desse fim. A exigência filosófica de verdade impõe, dessa forma, como princípio do discurso do método, em caráter permanente, a cauta admissão das ciências humanas, em estado de simpósio: cada qual é capaz de iluminar a obra, e nenhuma, por si só, traz a completa chave de sua decifração. Filosoficamente, o objeto literário permanece inesgotável.

Sua crítica, portanto, advinda da tensão provocada pela linguagem literária, empenhase na construção de um discurso reflexivo que, ao pôr em relevo o literário, ao pensar acerca dele, abre-se para a discussão. Tanto quanto a sua leitura da obra literária, a leitura suscitada pela sua crítica leva o leitor a um questionar do texto artístico, do texto crítico, em um “exercício de conhecimento do mundo, de nós mesmos e dos outros”. (NUNES, 1998, p.175)

\footnotetext{
49 Embora "a tal ponto a imagem está hoje introjetada na palavra poética que a mera menção do tema - palavra e imagem - parece conduzir o pensamento inexoravelmente para a poesia” (SANTAELLA \& NÖTH, 1998, p.71); o nosso discurso verbal, independente do poético, é permeado de imagens. Cf. SANTAELLA, Lúcia \& NÖTH, Winfried. Imagem - cognição, semiótica, mídia. São Paulo: Iluminuras, 1998.

${ }^{50}$ Para Leyla perrone-Moisés (1978, p.65-6): “a fronteira entre a obra poética e a obra crítica continua estável até nossos dias. Isto porque a distinção entre os dois tipos de obra é mais do que uma simples distinção genérica. A crítica não é nem literatura, nem não-literatura; é uma espécie de paraliteratura, quase diríamos uma párialiteratura”.
} 


\section{II.2. O confronto de idéias estéticas e poéticas}

A crítica literária de Benedito Nunes, como vimos no primeiro capítulo, nasceu sob o influxo cultural da década de 50, em cuja segunda metade assiste-se, por exemplo, ao surgimento da primeira Bienal, ao aparecimento de museus de arte moderna, às manifestações de retomada das vanguardas. O debate crítico central nesse período girava em torno da questão da linguagem poética, do qual os poetas-críticos - Mário Faustino, Augusto e Haroldo de Campos, Décio Pignatari e Ferreira Gullar - são representativos na luta contra o prosaísmo, que, ao lado do poético, são entendidos como “pólos extremos da linguagem” e na defesa da tradução como "instrumento crítico poderoso do conhecimento das qualidades estéticas dos poemas”. (NUNES, 2000, p.63)

O privilégio concedido à poesia no repertório cultural de Nunes (Cf. 2000, p.54) muito se deve ao seu interlocutor e amigo Mário Faustino que, na esteira de Erza Pound ${ }^{51}$, considerava que esta se afirmava "pela tensão que guarda relativamente ao pólo discursivo da prosa da qual se distancia”. (NUNES, 1978, p.123)

Tal tensão marca uma época em que as criações poéticas, avessas ao “discursivosentimental” (FAUSTINO, 1977, p.218), próximas à “renovação da linguagem, em termos de informação estética” (CAMPOS, 1992, p.13), exigiam do crítico uma resposta propositiva, uma permanente disposição de renovar suas preferências, suas escolhas, na busca de tentar apreender a imprevisibilidade e a inconstância do literário.

Esta “tensão entre a leitura crítica e a escrita dos escritores”, da qual o exercício crítico de Nunes se configurou, assinala que estudar as vicissitudes do poético é pôr em perspectiva um momento da história literária em conexão com a Historiografia nacional - Historiografia, importante ressaltar, compreendida como escrita da história.

No texto “Historiografia literária do Brasil”, constante no Crivo de papel (1998), Benedito Nunes lembra que a Historiografia em nosso país surge a partir do evento da Carta de Pero Vaz de Caminha e se legitima com a Independência de 1822; portanto, no chamado período romântico. Seriam os românticos, assim, os principais construtores da Historiografia literária do Brasil. Entretanto, o estado da literatura anterior à Independência já se configurava

\footnotetext{
51 O método poundiano de Mário Faustino pode ser conferido, entre outros livros, em FAUSTINO, Mário. Poesia-experiência. São Paulo: Ed. Perspectiva, 1977 (introdução de Benedito Nunes). As reflexões-chave de Pound a respeito da poesia a que Faustino se refere encontram-se em POUND, Erza. ABC of reading. London: Faber and Faber, 1961.
} 
como o "preliminar esboço de um domínio literário único a caminho de sua completa autonomia”. (NUNES, 1998, p.206)

Comentar da autonomia artística, por sua vez, é explanar a respeito dos discursos que a envolve, como o estético e o crítico. O discurso estético, como apresentado anteriormente, localiza-se no universo da cultura, em que, em intercâmbio com outros discursos, integra o saber de uma época em dependência tanto das idéias principais do conhecimento quanto dos liames significativos da vida social. Só podemos examiná-lo ao se ter em vista os dados da história cultural que o confirma tanto no contexto dos planos literários e artísticos, quanto nos valores morais, religiosos e políticos de que compartilha a inteligência habituada à especulação filosófica ou ao exercício da crítica.

Para que melhor possam ser entendidos os reclamos da crítica de Benedito Nunes dentro da nossa Historiografia literária, antes de se avançar na reflexão, faz-se necessário pontuar os confrontos estéticos e poéticos que compõem essa História. Buscar a historicidade, contudo, é preocupar-se menos com a história no texto, que com o "modo pelo qual foi possível estabelecer as condições para a internalização da história no texto”. (BARBOSA, 1996, p.175) É imperioso ressaltar, porém, que não se trata de um estudo aprofundado da história e da crítica literária. Trata-se apenas de iluminar as linhas gerais que compõem este estudo e dos autores mais representativos do período correspondente.

Após a breve incursão, sublinhar-se-á o momento do exercício crítico do professor paraense, ele próprio marcado por textos que resgatam a Historiografia da literatura e da crítica $^{52}$, tais como “O pensamento estético no Brasil” (1978); “Historiografia literária do Brasil” (1998); “Crítica literária no Brasil, ontem e hoje” (2000), entre outros. Ao tangenciálos, tentar-se-á pôr em relevância a leitura que Benedito Nunes faz da história e da crítica literárias.

\section{II.2.1. Diretrizes da historiografia literária e da crítica nacional}

Segundo Nunes (1978), na nossa história cultural, a partir da segunda metade do século XIX, o pensamento estético seguiu as reviravoltas da filosofia e da crítica. Até 1922, a reflexão estética recebeu influências de fontes oitocentistas e suas principais concepções foram projetadas pela crítica literária. Isto porque, a literatura, como fonte de sistema de

\footnotetext{
${ }^{52}$ A questão do resgate historicista no discurso de Nunes será retomada no item II.4. (O perfil da linguagem crítica: o traço da historicização e o uso do ensaio), p.160.
} 
saber, estabilizou-se por meio do nacionalismo e da crítica nascente sob orientação sociohistórica ${ }^{53}$.

De acordo com Bernard Bosanquet (1970, p.196) ${ }^{54}$, a caracterização da Estética moderna, desde a sua origem kantiana, resultou da intersecção entre o interesse especulativo e o interesse crítico.

O interesse especulativo, na Europa, ligou-se às ciências físico-matemáticas do século XIX: o evolucionismo do naturalista alemão Ernst Haeckel (1834-1919), a filosofia evolucionista do inglês Herbert Spencer (1820-1903) e o positivismo de Auguste Comte (1798-1876). No Brasil, o interesse crítico foi firmado, na época do Romantismo, às voltas com o caráter nacional, em uma perspectiva filosófica, contrária ao ecletismo da primeira geração romântica ${ }^{55}$. Já na geração de 1870 prevalecia uma linha de natureza histórica, de que derivou a Escola do Recife ${ }^{56}$, de padrões realista-naturalista e do germanismo presentes, por exemplo, na crítica de Sílvio Romero (1851-1914) ${ }^{57}$ em História da Literatura Brasileira (1888).

Importante destacar a questão do impasse de que nos aponta João Alexandre Barbosa ${ }^{58}$ a respeito da caracterização de José Veríssimo (1857-1916) como pertencente, em sua primeira fase, a essa "geração de 70". Tal impasse ocorre entre a posição de Veríssimo contestador do critério de nacionalidade e a sua dificuldade de atingir "uma linguagem específica da crítica literária”. (BARBOSA, 1974, p.145)

O fato é que, nesse momento, crítica e história literária, unidas na nossa cultura, apontavam ora para o viés nativista, ora para o viés nacionalista da evolução da literatura, “mas não sem reparos corretivos como os de Sílvio Romero, em nome de uma espécie de culturalismo, e os de José Veríssimo, em nome da literatura como arte”. (NUNES, 2000, p.55)

\footnotetext{
${ }^{53}$ Dois livros de Antonio Candido são fundamentais para melhor entendimento da literatura e da crítica nesse período: Formação da Literatura Brasileira. vol. II. $6{ }^{a}$ ed. São Paulo: Itatiaia, 1981, p.9-25; e Literatura e Sociedade. 8 a ed. São Paulo: T. A . Queiroz Editor, 2000.

${ }^{54}$ Cf. BOSANQUET, Bernard. Historia de la estética. Buenos Aires: Nueva Visíon, 1970.

${ }^{55}$ Acerca da literatura anterior a Sílvio Romero, conferir, entre outros, COUTINHO, Afrânio. Introdução à literatura no Brasil. 13a edição. Rio de Janeiro: Berthand Brasil S.A.,1988, p.29.

${ }^{56}$ A Escola do Recife teve importante papel na divulgação das idéias evolucionistas e positivistas. Além de Sílvio Romero, destacam-se, entre outros, Tobias Barreto (1833-1891), Araripe Júnior (1848-1911), Rocha Lima (1897-1969), Clóvis Bevilácqua (1859-1944) e Capistrano de Abreu (1853-1927).

${ }^{57}$ A respeito da crítica de Sílvio Romero Cf. CANDIDO, Antonio. O método crítico de Sílvio Romero. São Paulo: Editora da Universidade de São Paulo, 1988.

${ }^{58}$ Cf. BARBOSA, João Alexandre. A tradição do impasse. Linguagem da crítica e crítica da linguagem em José Veríssimo. São Paulo: Ática, 1974.
} 
A reflexão estética, entremeada à Crítica, nas duas últimas décadas do século XIX, teve influência do naturalismo filosófico de Hippolyte Taine (1828-1893); de Jean-Marie Guyau (1854-1888) e do crítico Émile Zola (1840-1902).

De Zola, nossa crítica buscou assimilar as suas idéias sobre o meio hereditário e ambiental, que envolviam “as sociedades em sua vida real”. Essa questão permitiu que houvesse uma equivalência entre "o valor estético e o nativista das obras”, ponto fundamental do nacionalismo crítico, nascido no Romantismo, e que possibilitou iniciar, em volta da forma de expressão, um debate que culminou no “problema limite da essência da Arte”. (NUNES, 1978, p.92)

A tríade de Taine - o meio, a raça, o momento - formaram um conjunto que, historicamente, explicariam o desenvolvimento e a função da Arte. O conceito raça teve influência na História da Literatura (1888), de Sílvio Romero, e n' A Arte Brasileira (1888), de Luiz Gonzaga Duque Estrada (1863-1911), obras matrizes da orientação sociohistórica da Crítica.

No quadro de tal orientação, unida ao rumo do desenvolvimento, Sílvio Romero conjeturou o lugar da Estética, ciência da Arte. Da Estética depende a Crítica, presa que está ao conhecimento elaborado de qualquer ramo daquela, e que, no âmbito da análise interpretativa, se emprega aos resultados de todas as ciências. Esse conceito de Crítica, que Sílvio Romero chamou de criticismo, influenciou a Escola do Recife e perdurou até a segunda década do século XX.

Porém, Romero não aceitava o naturalismo literário de Zola, pois achava que a criação artística é um produto da cultura e não da natureza ${ }^{59}$. Essa questão, assim, desmentia o fundamento naturalista da teoria sistemática que o representante da Escola do Recife desenvolveu nos estudos da literatura e do folclore brasileiros. Tal contradição teórica estendeu-se para a Crítica, incapaz de construir um vínculo entre o caráter nacional das obras, "medida de seu valor estético, e a evolução do país que elas deveriam representar, de acordo com a perspectiva sociológica e historicista que respaldou o nacionalismo crítico da época, ao qual jamais faltou, tanto em Sílvio Romero quanto em José Veríssimo, um constante empenho político”. (NUNES, 1978, p.95)

\footnotetext{
${ }^{59}$ Cf. ROMERO, Sílvio. Movimento Espiritual do Brasil no ano de 1888. In: Novos estudos de literatura contemporânea. Rio de Janeiro/Paris: H. Garnier, s.d., p.120.
} 
Com efeito, para Sílvio Romero, a leitura crítica deveria ressaltar a formação e o caráter nacionais como medida de valor estético. O mesmo preceito era assumido por José Veríssimo, que criticava os romances naturalistas, pois nesses faltavam a representação da natureza e da vida brasileiras. No entanto, Veríssimo apreciava Machado de Assis, uma vez que a obra do autor de Memórias póstumas de Brás Cubas (1881) não podia, segundo ele, ser julgada pelos mesmos critérios ${ }^{60}$.

No mesmo período, Araripe Júnior (1848-1911) ${ }^{61}$, que aceitava a doutrina spenceriana e a perspectiva sociológica, reconhecia como valor da literatura, para além das questões regionalistas e do nacionalismo, a universalidade da Arte como aquela capaz de corresponder aos anseios de ordem estética ${ }^{62}$.

Contudo, esses anseios de ordem estética, na passagem do século XIX para o século XX, incidiram no esteticismo. Tal fenômeno, sobre o qual Nunes esboça um quadro significativo no texto “O pensamento estético no Brasil” (1978, p.98-108), pode ser resumido por um estilo de auto-suficiência acadêmica, por uma linguagem técnica e apurada e por uma configuração que espelhava a forma dos autores europeus.

Essas conotações referem-se ao momento do Realismo naturalista na prosa e do Parnasianismo na poesia. Do Naturalismo filosófico se ligará uma interpretação espiritualista da cultura, oposta às idéias introduzidas em 1870. Essa reação espiritualista, atrelada ao esteticismo, repercutiu entre os críticos ligados ao simbolismo, como no ensaísmo de Tasso da Silveira (1895-1968) ${ }^{63}$ e de Nestor Victor (1868-1932) ${ }^{64}$. Aliás, a voz de Farias Brito ${ }^{65}$ já ressoava contrária à Escola do Recife, na luta contra as chamadas “doutrinas de dissolução” o materialismo e o positivismo -; voz a quem os pensadores católicos, como Jackson de

\footnotetext{
${ }^{60}$ Cf. VERÍSSIMO, José. “O Sr. Machado de Assis”. In: Estudos Brasileiros - segunda série (1889-1993). Rio de Janeiro: Laemmert Editores, 1894, p.198-9.

${ }^{61}$ Para melhor conhecer seus textos Cf. ARARIPE JÚNIOR, Tristão de Alencar. Araripe Júnior: teoria, crítica e história literária. Seleção e apresentação de Alfredo Bosi. Rio de Janeiro: Livros Técnicos e Científicos; São Paulo: Editora da Universidade de São Paulo, 1978.

${ }^{62}$ Cf. MONTENEGRO, Pedro Paulo. A teoria literária na obra crítica de Araripe Júnior. Rio de Janeiro: Tempo Brasileiro, 1974, p.42-3.

${ }^{63}$ Nunes (1978, p.105) cita como exemplo de ensaísmo o texto A Igreja Silenciosa (1922), "bafejado pela influência de Emerson e dedicado à busca de uma forma de filosofia perene que correspondesse à expressão dos sentimentos elevados em poesia”. (grifo do autor)

${ }^{64}$ A respeito do momento parnasiano-simbolista na crítica em geral e do estudo de críticos, em particular, como Nestor Victor, Araripe Júnior, José Veríssimo, Adolfo Caminha, João Ribeiro, Sílvio Romero, Elísio de Carvalho, entre outros Cf. CARA, Salete de Almeida. A recepção crítica: o movimento parnasiano-simbolista no Brasil. São Paulo: Ática, 1983.

${ }^{65}$ Cf. NUNES, Benedito. Farias Brito - trechos escolhidos. Rio de Janeiro: Agir, 1967. Como apresentação geral de suas idéias Cf. item I.2.8 (Farias Brito), p.50-2.
} 
Figueiredo (1891-1928), Leonel Franca (1893-1948) e Alceu Amoroso Lima (1893-1983) ${ }^{66}$, aderiram.

Representativo do esteticismo, o texto A Estética da Vida (1921), de Graça Aranha (1868-1931), de cunho ideológico, “fundiu, num quadro metafísico espectral, o monismo evolucionista e as últimas colorações do idealismo germânico”. (NUNES, 1978, p.101) Sua Filosofia da Arte também seria a síntese filosófica da religião e da ciência, concomitantemente, estética da vida e vida como estética, corporificada em uma ética nacionalista, que tentou adequar-se, durante o curso do movimento modernista, em O Espírito Moderno (1925), ao entendimento da arte do século XX, na direção de uma ideologia do progresso que prendeu o seu autor ao futurismo italiano.

Ainda é pertinente lembrar, nesse período, do crítico João Ribeiro (1860-1934) ${ }^{67}$, “ensaísta versátil, irônico para com as pretensões judicativas da crítica, cético em relação ao endeusamento da ciência”. (NUNES, 1978, p.108) Em Páginas de Estética (1905), transpôs à literatura, com fundamento nas imagens psíquicas que as palavras sugerem, o intuitivismo, cuja idéia iniciou a teoria da essência lírica da expressão artística desenvolvida, depois, pelos modernistas.

Para o também crítico Augusto Meyer (1902-1970), o ensaísmo de João Ribeiro pode ser caracterizado como de superação do ensaio por uma poesia do ensaio ${ }^{68}$. Aliás, a mesma qualidade é atribuída ao autor gaúcho de À sombra da estante (1947) e Preto \& Branco (1956) por João Alexandre Barbosa ${ }^{69}$.

A segunda década do século XX, com o movimento modernista de fevereiro de 1922, seria marcada, segundo Nunes (2000, p.56), como o momento de maior tensão entre a leitura dos críticos e a escrita dos escritores. Isto porque, o Modernismo brasileiro teve dupla expressão histórica: de um lado, ligou-se às correntes estéticas européias - o Futurismo, o Cubismo, o Dadá e o Surrealismo - que lhe legaram uma renovação artística e cultural. De outro, conservava-se preso à tendência nacionalista, herdeiro do nacionalismo crítico e da inclinação sociohistórica da segunda metade do século XIX.

\footnotetext{
${ }^{66}$ Como referência de estudo Cf. ATHAYDE, Tristão. Teoria, crítica e história literária. Seleção e apresentação de Gilberto Mendonça Teles. Rio de Janeiro: Livros Técnicos e Científicos Editora/INL, 1980.

${ }^{67}$ A respeito da crítica de João Ribeiro Cf. SCHNAIDERMAN, Boris. João Ribeiro Atual. In: Revista do IEB, ${ }^{\circ}$ 10. São Paulo: Instituto de Estudos Brasileiros da Universidade de São Paulo, 1971.

${ }^{68}$ Cf. MEYER, Augusto. João Ribeiro ensaísta. In: Textos críticos. Seleção e introdução de João Alexandre Barbosa. São Paulo: Perspectiva; Brasília: INL, Fundação Nacional Pró-Memória, 1986, p.307-319.

${ }^{69}$ Cf. BARBOSA, João Alexandre. Augusto Meyer ensaísta. In: Revista Cult - ano V, n ${ }^{\circ}$ 54, janeiro de 2002, p.14-7.
} 
Essa oscilação foi caracterizada por João Luiz Lafetá (2000, p.19) como a passagem do "projeto estético" dos anos 20 ao "projeto ideológico" dos anos 30; “duas faces (complementares e, aliás, intimamente conjugadas; não obstante, às vezes relacionadas em forte tensão)”. A primeira refere-se às modificações operadas na linguagem; a segunda, à visão da realidade brasileira orientada pela direção nacionalista ${ }^{70}$.

Os manifestos (Pau-Brasil, 1924; Verde-Amarelo, 1926; Antropófago, 1928), bem como as revistas (Klaxon, 1922; Estética, 1924; Nova, 1926; Festa, 1927; Revista de Antropofagia, 1928-1929) são exemplos desse conflito ora estético, ora ideológico ${ }^{71}$.

Sem dúvida, o crítico ou poeta-crítico que se destaca nesse período é Mário de Andrade (1893-1945), que "vive com particular dramatismo a tensão entre sua sensibilidade de artista, cônscio das exigências da escritura, e seus impulsos de intelectual à procura do melhor desempenho no papel de formador da nacionalidade e/ou no trabalho de construção social”. (LAFETÁ, 2000, p.154)

Tanto o seu prólogo a Paulicéia desvairada (1922), o “Prefácio interessantíssimo”, continuado em A escrava que não é Isaura (1924), quanto os seus artigos O empalhador de passarinhos (1940) e O baile das quatro artes (1943) atestam a reconceituação do fenômeno artístico.

Mário de Andrade, junto com Oswald de Andrade (1890-1954) ${ }^{72}$ de Ponta de Lança (1945), são tributários de uma literatura mais reflexiva, propensa à parodia, ao humor e à ambigüidade, em harmonia com as transformações da modernidade.

Nessa fase, Nunes (1978, p.113; 2000, p.58) recorda que havia basicamente dois tipos de crítica: a crítica interna, aliada à criação; e a crítica externa, que julgava obras do passado, como realizaram, entre outros, Mário e Oswald de Andrade, Alceu Amoroso Lima (Tristão de Athayde) e Sérgio Milliet (1898-1966) ${ }^{73}$, no seu Diário crítico (1940-1956) e no Panorama

\footnotetext{
${ }^{70}$ Essas linhas foram estudadas por Lafetá em quatro críticos: Agripino Grieco, Tristão de Athayde, Mário de Andrade e Octávio de Faria. Cf. LAFETÁ, João Luiz. 1930: A crítica e o modernismo. 2a ed. Prefácio de Antonio Candido. São Paulo: Duas Cidades/Ed.34, 2000.

${ }^{71}$ Cf. SHWARTZ, Jorge. Vanguardas latino-americanas - Polêmicas, manifestos e textos críticos. São Paulo: EDUSP/Iluminuras/Fapesp, 1995.

${ }^{72}$ A importância da crítica e da poética de Mário e Oswald de Andrade, na leitura de Nunes, já foi esboçada no primeiro capítulo. Cf. item I.2.3. (p.43-4), Estética e Correntes do Modernismo (1975), e item I.2.4 (p.44-6) Oswald Canibal (1979).

${ }^{73}$ A respeito de Sérgio Milliet Cf. CANDIDO, Antonio. O ato crítico. In: A educação pela noite \& outros ensaios. $3^{\mathrm{a}}$ ed. São Paulo: Ática, 2003, p.122-137.
} 
da moderna poesia brasileira (1952). Da crítica literária de Álvaro Lins (1912-1970) ${ }^{74}$, veiculada nos rodapés dos jornais, Nunes (2000, p.60) comenta que este autor era preocupado, sobretudo, com a procura da “determinação das influências de um autor sobre outro, como de Virgínia Woolf sobre Clarice Lispector ou da utilização das formas tradicionais - como da tragédia no teatro de Nélson Rodrigues, Vestido de noiva e Álbum de família”.

Por certo, Tristão de Athayde teve um papel relevante na crítica jornalística. No início, é nítida a influência do impressionismo francês de Anatole France (1844-1924), Jules Lemaître (1853-1914) e Remy de Gourmont (1858-1915), antes de conformar-se ao expressionismo de Benedetto Croce (1866-1952). Na sua obra, percebe-se certo embaraço nas relações entre literatura e história, principalmente, quando abraça uma posição mais religiosa, em que se sobressai os valores históricos sobre os literários, "não obstante o discurso de acomodação entre os dois a partir de uma posição a que se tem chamado (sem definição, mais precisa do termo) de 'humanista'”. (BARBOSA, 1990, p.56) Essa subordinação - da História literária à História geral - pode ser encontrada em livros como Quadro sintético da literatura brasileira (1956) e Introdução à literatura brasileira (1956). Em Crítica literária no Brasil (1959), apresenta uma evolução da crítica dividida em três fases: a inicial, a constitutiva e a moderna. Esta última se amplia em três momentos: o impressionismo (1900-1920); o humanista (1920-1945) e o formalista (1945).

Tal categorização é questionada por, entre outros, João Alexandre Barbosa (19372006), embora ele reconheça que todas as classificações, e não só a de Athayde, "implicam, quase sempre, a ambivalência entre generalização e sumário com o conseqüente rapto das distinções mais elaboradas e específicas”. (BARBOSA, 1990, p.68)

Pode-se lembrar, nessa mesma linha, o estudo de Wilson Martins (1921-) - A crítica literária no Brasil (2002) -, que, por sinal, qualifica a crítica de Benedito Nunes de Formalismo ou "Linhagem Formalista ou 'estética”" em cinco momentos na sua obra: 1. ao explicar que, na década de 60, há uma identificação entre crítica e gramática. Daí o surgimento de livros "na confluência de ramos colaterais, legítimos e bastardos de gramáticos, humanistas e formalistas (...) [como] O Mundo de Clarice Lispector, de Benedito Nunes, que também organizou nesse ano [1966] a Poesia, de Mário Faustino, escrevendo-lhe uma introdução”. (vol.2, p.157); 2. quando se refere à família estética ou formalista como

\footnotetext{
${ }^{74}$ Cf. SANTOS, Veronilda e FRANCO, Lúcia Helena C. (orgs.). Contribuição à crítica literária brasileira Álvaro Lins: inventário bibliográfico e documental. Recife: Biblioteca Central Blanche Knopf da Fundação Joaquim Nabuco, 2005.
} 
subdividida em dois ramos, o primeiro em "temas gerais e teoria”; o segundo em "análises de autores individuais: (...) [como] João Cabral de Melo Neto, por Benedito Nunes” (vol.2, p.167); 3. no "quadro da crítica formalista: (...) O dorso do tigre, de Benedito Nunes” (vol.2, p.181); 4. "Linhagem formalista: (...) Benedito Nunes (Leitura de Clarice Lispector)” (vol.2, p.220); e 5. representantes do tema de história literária, que "estavam preocupados com panoramas, muitas vezes superficiais e simplificadores e estudos de escritores individualmente considerados (...) [como] Benedito Nunes (Oswald Canibal)”. (vol.2, p.294)

Tais qualificações, como são óbvias, não ajudam a perceber a dimensão da escrita nuneana e um rótulo, como o de "formalista", dificilmente pode dar conta de abarcar a especificidade do seu exercício crítico.

Sob esse prisma, a proposta de Barbosa (1990) ${ }^{75}$ é mais coerente. Seu trabalho se caracteriza por discutir as relações de tensão entre a análise formal e a interpretação histórica, que, segundo defende, torna capaz de recuperar os momentos da evolução da crítica literária brasileira, sem deixar de lembrar os fundamentos históricos, e sem deixar de assinalar a continuação de uma problemática qualquer que consegue atingir a contemporaneidade.

O roteiro que estabelece é composto por três etapas que se articulam: a herança, a ruptura e a releitura. A herança é referente às obras críticas que prepararam caminho para uma renovação dos estudos lingüísticos, bem como repensaram a idéia de estilo e sua inclusão em um contexto histórico-social mais extenso e dinâmico. Como exemplo, cita os textos de Augusto Meyer, entendidos como "uma écriture em que a análise e a interpretação terminam por realizar uma fusão admirável”. (BARBOSA, 1990, p.67)

As fases da ruptura e da releitura são próximas à leitura que Benedito Nunes (1978; 1998; 2000) faz da década de 40 em diante. Para ambos, a literatura produzida a partir dos anos 40 - uma prosa como a de Clarice Lispector ou de Guimarães Rosa - demandava uma linguagem crítica mais refinada, para que pudesse acompanhar as inovações do código literário. A ruptura, portanto, é correspondente à própria evolução constatada na criação de uma literatura. Já a crítica como releitura ocorre a partir dos anos 60 e é definida como a “possibilidade de uma decodificação que atende não somente para os elementos constituintes

\footnotetext{
75 Vale lembrar que, originalmente, o texto “Forma e História na crítica brasileira - de 1870-1950” chamava-se “Algumas reflexões sobre a crítica brasileira contemporânea”, de setembro de 1984, mas foi apresentado, em 1986, na $2^{\text {a }}$ Bienal Nesthé de Literatura e publicado em PROENÇA FILHO, Domício (org). Literatura Brasileira - ensaios, criação, interpretação e leitura do texto literário. Vol.I. São Paulo, Norte, 1986, p.104118.
} 
da literariedade como para o que, no texto, envolve a sua existência como radicação na história”. (BARBOSA, 1990, p.75)

Tanto Barbosa (1990, p.70-2) quanto Nunes (1978, p.123-4; 1998, p.239-43; 2000, p.64-8) comentam da importância de Afrânio Coutinho (1911-) e Antonio Candido (1918-) ${ }^{76}$ como autores que refletiram as relações entre Crítica e História e deixaram obras críticas paradigmáticas nesse sentido.

Afrânio Coutinho, vinculado à tradição do New Criticism, destacou-se por ter tido uma preocupação metodológica baseada em critérios estético-estilísticos. Em, por exemplo, Correntes cruzadas e Por uma Crítica Estética (1953); Da Crítica e da Nova Crítica (1957), “postulou (...) uma crítica rigorosa que, análoga à ciência como atividade intelectual e reflexiva, fosse antes de tudo um método específico de análise”. (NUNES, 1978, p.123) A especificidade desse método foi emblema de uma Nova Crítica, como ficou conhecida.

Já a contribuição de Antonio Candido como crítico vai além de uma aplicação do método sociológico, pois ele se utiliza, antes, de uma interpretação sociohistórica, atenta ao ““social’, ao 'psicológico’ e ao 'estético’, experienciada em diferentes instâncias, como na história literária, em que produziu, em 1959, Formação da literatura brasileira, ao mesmo tempo livro de crítica e de história”. (NUNES, 2000, p.66)

Ainda a respeito da questão entre leitura histórica e interpretação, João Alexandre Barbosa (1990, p.70) e Benedito Nunes (1998, p.238; 2000, p.60-1) citam os autores Sérgio Buarque de Holanda (1902-1978), em O espírito e a letra (1996); Lúcia Miguel Pereira (1903-1959), em Tendências e repercussões literárias do Modernismo (1953); Otto Maria Carpeaux (1900-1978), em História da literatura ocidental (1959-1966, 8 vol.); e Brito Broca (1903-1959), em A vida literária no Brasil - 1900 (1955), cujas obras revelavam as discussões de conceitos e critérios, em que se dirigiu, assim, o exercício crítico.

Dos anos 50 até por volta de 1970, o debate crítico tem seu auge no jornalismo literário, grande era o número de periódicos que o veiculava: Correio da Manhã, Diário de Notícias, A Manhã, O Estado de S. Paulo, Jornal do Brasil, Suplemento Literário de Minas Gerais, entre outros. Como já comentado no primeiro capítulo ${ }^{77}$, Benedito Nunes se inscreve

\footnotetext{
${ }^{76}$ É pertinente assinalar que Wilson Martins (2002, vol.2, p.32) também elogia o trabalho crítico de Antonio Candido, mas acredita que Afrânio Coutinho foi "apenas um vulgarizador de doutrinas alheias, simplificando-as, não raro, por meio de polarizações antagonizadoras que teriam certamente surpreendidos os formuladores originais da doutrina”. Cf. MARTINS, Wilson. A crítica literária no Brasil. Vol. 2. $3^{\text {a }}$ ed. Rio de Janeiro: Francisco Alves/Imprensa Oficial do Paraná, 2002, p.55-60.

${ }^{77}$ Cf. item I.2. (O ensaísmo crítico), p.35-6.
} 
como um dos críticos dessa fase, ao lado de, por exemplo, Afrânio Coutinho, Antonio Candido, Wilson Martins, Eduardo Portella (1933-), Aderaldo Castelo, Fausto Cunha (19232004), Fábio Lucas (1931-) e Euryalo Cannabrava (1911-).

A partir dos anos sessenta, a crítica brasileira também passou a ser produzida nas universidades e divulgada por meio de revistas especializadas e livros, especialmente fundamentada pela Teoria da Literatura, que “daria um novo acesso, menos preconcebido, às Ciências Humanas e à Filosofia, à História e à Hermenêutica”. (NUNES, 1999a, p.17)

De um modo geral, vigorava, desde o advento da Poesia Concreta (1956), uma consciência reflexiva da linguagem poética, “condicionada às transformações materiais (...) da sociedade industrial avançada, e de que a crise do verso, que teria se consumado em Mallarmé, indicava o ponto de ruptura” (NUNES, 1978, p.125), na busca de um processo evolutivo das formas artísticas.

Os críticos-poetas desse momento - Augusto de Campos (1931-), Décio Pignatari (1927-) e Haroldo de Campos (1929-2004) - procediam a uma reavaliação da história literária de maneira sincrônica ${ }^{78}$ e buscavam uma forma de questionamento crítico e ensaístico, por meio do trabalho de tradução como recriação do texto.

No mesmo período, surge o grupo Tendência ${ }^{79}$ - Affonso Ávila (1928-), Fábio Lucas (1931-) e Rui Mourão (1929-) - que reavivou a orientação nacionalista e que, mais tarde, se articularia aos concretistas. Também dessa fase, Mário Chamie (1933-) publicou o livro Lavra Lavra (1962), que originou a revista Praxis e o grupo do mesmo nome, cujo programa residiu na tentativa de desenvolver uma ligação entre as práticas sociais e as artísticas, contrário a uma primeira fase da Poesia Concreta. Depois, como é de conhecimento geral, esta teve uma orientação mais social-política ${ }^{80}$.

Da constante interrogação de como se fazer crítica em meio a novas criações literárias, é possível identificar variadas tendências que se expandiram no Brasil. Nunes (2000, p.62) indica, no entanto, que ora de modo direto, ora de modo indireto, essas posições encontrariam base nas diferentes correntes filosóficas em vigência e esse fazer não pode ser de todo independente:

\footnotetext{
${ }^{78}$ Cf.CAMPOS, Haroldo. Por uma poética sincrônica. In: A arte no horizonte do provável. $4^{\mathrm{a}}$ ed. São Paulo: Perspectiva, 1977, p.205-12.

${ }^{79}$ Tendência também era o nome de uma Revista que foi publicada de 1957 a 1962.

${ }^{80}$ Cf. AGUILAR, GONZALO. Poesia em tempos de agitação. In: Poesia concreta brasileira - as vanguardas na encruzilhada modernista. São Paulo: EDUSP, 2005, p.87-116.
} 
Às vezes, a moda, a avidez da novidade aliciam o julgador literário. Mas queira-o ou não, o seu ponto de vista sempre se move entre presente e passado, segundo expectativas razoáveis do futuro da produção poética. É um ponto de vista reticulado, nunca isento filosoficamente. Sabe-se que os formalistas russos se formaram na fenomenologia de Husserl. O estruturalismo francês cresceu em sintonia com a lingüística saussuriana.

Desse modo, as investigações teóricas e críticas firmadas nesse momento recebiam contribuições não só do Marxismo, como noção geral da vida social e histórica, ao lado das teorias sociológicas e historicizantes, mas também da filosofia francesa dos valores (Louis Lavelle), além do Neopositivismo, coligado à propensão cientificista, da Semiótica, da Fenomenologia e da Hermenêutica.

Entre 1950 e início dos anos 60, instarou-se o regime militar de 1964: durante esse intervalo, a crítica se dividia entre marxistas e não-marxistas, estes ligados às filosofias da existência. Esse conflito impulsionou a discussão em torno da linguagem poética, da qual participaram os poetas-críticos, já mencionados, e também Ferreira Gullar (1930).

Da dúvida se poderia haver ou não uma poesia engajada, estabeleceu-se um confronto entre ideologia e estética, liberdade de criação e comprometimento social e político, de que os livros, de cunho existencialista sartriano, O desemprego do poeta (1962), de Affonso Romano de Sant’Anna, e O poeta e a consciência crítica (1969), de Affonso Ávila, são exemplares.

Aliás, a Hermenêutica de Sartre chega até nós antes da de Merleau-Ponty e a de Heidegger, que se estabelecem no mesmo período que o estruturalismo francês.

No livro Conversas com Filósofos Brasileiros (2000a, p.78), perguntado sobre a sua relação com os três paradigmas teóricos que marcaram o ambiente da década de 60 - o estruturalismo, o existencialismo e o marxismo - assim manifestou-se Benedito Nunes:

\begin{abstract}
A minha relação mais profunda e constante foi com a filosofia da existência, e isso se localizou sobretudo em Heidegger. No entanto, escrevi sobre Lévi-Strauss, À margem do estruturalismo, quando estava ainda na França. Nesse momento, LéviStrauss ocupava o mesmo lugar que Merleau-Ponty ocupara antes na França. Na verdade, foi pelo estruturalismo, confirmado pela obra de Foucault, que entramos na questão da linguagem. $\mathrm{O}$ estruturalismo teve essa grande virtude: chamar a atenção para a linguagem. Les mots et les choses é um livro fundamental, embora Foucault tendesse a desvalorizá-lo, achando que era circunstancial. (...)

Beneficiei-me muito da obra de Lefèvre, da sua interpretação do marxismo. Não só da flexibilidade com que o lê, mas por um tópico a que ninguém ainda prestou atenção: a metafilosofia, que é a retórica da filosofia. Essa minha preocupação de relacionar filosofia e poesia se aproveitou muito dessas idéias de Lefèvre, não da parte da poética, mas da parte da retórica. Há uma diferença entre a poética e a retórica: na poética é preciso entrar nas metáforas, nas figuras de linguagem; já na parte da retórica é preciso reparar nos meios de persuasão. Uma é atinente ao discurso, e outra é atinente às imagens faladas ${ }^{81}$.
\end{abstract}

\footnotetext{
${ }^{81}$ Comentarei esse assunto mais adiante.
} 
Do Estruturalismo Francês, há de se destacar o método de Lévi-Strauss, discutido em Estruturalismo e teoria da literatura (1973), de Luiz Costa Lima (1937-), e A estética de Lévi-Strauss (1975), de José Guilherme Merquior (1941-1991). Tanto Costa Lima quanto Merquior se ocupam do repensar do conceito de mímesis e ambos apresentam um ensaísmo crítico de investigação histórica, sociológica e política.

Merquior examina, além disso, a Escola de Frankfurt (Adorno, Horkheimer e Benjamin), a iconologia de Panovsky e a semiótica estética de Mukarovsky ${ }^{82}$.

O Estruturalismo assim como o Formalismo Russo foram objetos, muitas vezes, de simplificações e reducionismo. Um estudo na linha contrária a essas manifestações é o livro Fronteiras imaginárias $(1971)^{83}$, de Fábio Lucas. Por outro lado, Adolfo Casais Monteiro (1908-1972), em Clareza e mistério da Crítica (1971) ${ }^{84}$, questiona os exageros não só do Estruturalismo, mas de todas as posições críticas que se apresentaram como ciência.

De uma forma ou de outra, não há como negar a importância das análises de Roman Jakobson (1896-1982) para o estudo da poesia ${ }^{85}$ e da crítica de Roland Barthes (1915-1980) ${ }^{86}$, embora ele próprio tenha acentuado a natureza heterogênea de sua obra, "mais preocupada em experimentar as novas teorias (psicanálise, estruturalismo e semiologia) do que em se submeter a elas”. (ROGER, 2002, p.161)

No entanto, nem o Estruturalismo, nem a crítica Fenomenológica, introduzida por Anatol Rosenfeld (1912-1973) ${ }^{87}$ no espaço da realização teatral e por Maria Luiza Ramos ${ }^{88}$ no espaço da poesia, conseguiram o êxito da perspectiva sociohistórica - êxito

medido quer pela sua reação positiva à pedra de toque das novas linguagens literárias em ascensão - as novelísticas de Guimarães Rosa e de Clarice Lispector e a poesia de João Cabral de Melo Neto, sobre que versaram estudos de primeira recepção da autoria de Antonio Candido, Roberto Schwarz e Luiz Costa Lima, quer

\footnotetext{
${ }^{82}$ Cf. MERQUIOR, J. G. Arte e sociedade em Marcuse, Adorno e Benjamin - ensaio crítico sobre a escola neohegeliana de Frankfurt. Rio de Janeiro: Tempo Brasileiro, 1969; e Formalismo e tradição moderna - o problema da arte na crise da cultura. Rio de Janeiro: Forense Universitária, 1974.

${ }^{83}$ Cf. especialmente os capítulos: "Estruturalismo e Crítica literária"; "O poliedro da crítica"; "Problemas da crítica e do Estruturalismo" e "Do estruturalismo e da 'Nova Crítica””. In: LUCAS, Fábio. Fronteiras imaginárias. Rio de Janeiro: Cátedra/MEC, 1971.

${ }^{84}$ Cf. MONTEIRO, Adolfo Casais. Clareza e mistério da crítica. Rio de Janeiro: Fundo de Cultura, 1961.

${ }^{85}$ Cf., em especial, os textos "Lingüística e poética" e "Os oxímoros dialéticos de Fernando Pessoa", respectivamente em JAKOBSON, Roman. Lingüística e Comunicação. Trad. I. Blikstein e José Paulo Paes. São Paulo: Cultrix, 1975; e JAKOBSON, Roman. Lingüística. Poética. Cinema. Trad. Haroldo de Campos et al. São Paulo: Perspectiva, 1970.

${ }^{86}$ Acerca da crítica de Roland Barthes Cf. PERRONE-MOISÉS, Leyla. Texto, Crítica, Escritura. São Paulo: Martins Fontes, 2005.

${ }^{87}$ Cf. ROSENFELD, Anatol. A estrutura da obra literária. In: Estrutura e problemas da obra literária. São Paulo: Perspectiva, 1976; e Texto/Contexto. $4^{\mathrm{a}}$ ed. São Paulo: Perspectiva, 1985.

${ }^{88}$ Cf. RAMOS, Maria Luiza. Fenomenologia da obra literária. Rio de Janeiro: Forense Universitária,1969.
} 
pela sua extraordinária continuidade até quase o início da década de 1990 (...). (NUNES, 2000, p.68-9)

Ainda neste recordar dos momentos críticos, pode-se sublinhar com Nunes (2000, p.70) a importância da corrente da Estética da Recepção, de Jauss e Iser, já comentada anteriormente $^{89}$, por meio da qual a crítica se volta para o questionar da sua própria função e da tentativa de explicar ou compreender o literário.

Com isso, há um repensar da história literária e uma revisão dos cânones, especialmente daqueles instituídos antes da independência política ${ }^{90}$. Da insatisfação com o close-reading e a estilística, amplia-se a crítica intratextual, desenvolvida por, entre outros, Davi Arrigucci Jr (1943-) ${ }^{91}$, Walnice Nogueira Galvão ${ }^{92}$ e Flora Süssekind (1955-) ${ }^{93}$.

Por outro lado, a crítica cultivada nos estudos de Silviano Santiago (1938-) $)^{94}$ volta-se “para o aclaramento, dentro da dialética de dependência colonial e universalidade metropolitana, do princípio de nacionalidade, utilizado como critério estético desde Sílvio Romero, e continuando na valorização da cultura nativa pelos modernistas”. (NUNES, 2000, p.72) Santiago retoma não só a antropofagia oswaldiana para examinar esse problema, mas também a teoria de Jacques Derrida (1930-2004), sobre a qual supervisionou um Glossário ${ }^{95}$.

A declarada crise da crítica discutida por, entre outros, Leyla Perrone-Moisés ${ }^{96}$, mesmo após este balanço de tendências e correntes, é talvez, como sugere Nunes (2000, p.745), crise da própria literatura, hoje “combalida, intoxicada, inconformada, maquilada dentro do vigente sistema de valores mediáticos da vida cultural brasileira globalizada”. Porém, ele próprio conclui: “(...) crise não é catástrofe. Crise é incerteza acerca do que fazer agora e do que virá depois”.

\footnotetext{
${ }^{89}$ Cf. item I.4.1 (Breves interfaces do pensamento hermenêutico), p.85-7.

${ }^{90}$ Cf. KOTHE, Flávio. O cânone colonial. Brasília: UNB, 1997.

${ }^{91}$ Cf. ARRIGUCCI JR., D. O cacto e as ruínas - a poesia entre outras artes. São Paulo: Duas Cidades, 1997; e Humildade, paixão e morte - a poesia de Manuel Bandeira. São Paulo: Companhia das Letras, 1990.

${ }_{92}$ Cf. GALVÂO, W.N. Desconversa. Rio de Janeiro: UFRJ, 1998; e Gatos de outro saco - ensaios críticos. São Paulo: Brasiliense, 1981.

${ }^{93}$ Cf. SÜSSEKIND, F. O Brasil não é longe daqui - o narrador, a viagem. São Paulo: Companhia das Letras, 1991; Cinematógrafo de letras - literatura, técnica e modernização no Brasil. São Paulo: Companhia das Letras, 1987; e A voz e a série. Rio de janeiro: Sette Letras, 1998.

${ }^{94}$ Cf. SANTIAGO, Silviano. Uma literatura nos trópicos. $2^{\mathrm{a}}$ ed. Rio de Janeiro: Rocco, 2000.

${ }^{95}$ Cf. DERRIDA, J. Glossário de Derrida. Trabalho realizado pelo Departamento de Letras da PUC/RJ. Supervisão de Silviano Santiago. Rio de Janeiro: Francisco Alves, 1976.

${ }_{96}^{6}$ Cf. PERRONE-MOISÉS, L. Que fim levou a crítica literária? In: Inútil Poesia. São Paulo: Companhia das Letras, 2000.
} 


\title{
II.2.2. O diálogo crítico de Benedito Nunes
}

Embora demasiadamente esquemático, esse pontuado das diretrizes historiográficas e críticas literárias, em especial a partir dos anos 50, abre a possibilidade de se perceber como a produção de Nunes se situa e dialoga com essas tendências. Ou melhor, como ele as acentua para compor uma experiência de leitura e de reflexão.

Tal diálogo, por certo, ocorre mais de perto com as correntes hermenêuticas, mas, como se percebe, Benedito Nunes tem a clareza e o discernimento necessários para repensar o exercício crítico. Isto porque, o conhecimento e o debate com outras linhas favorecem um constante renovar de posturas e idéias; um buscar incessante de se aperfeiçoar e de livrar-se de cristalizações para que a tarefa crítica possa ser um desafio, não uma aplicação de regras teóricas.

Os casos Carlos Drummond de Andrade e Clarice Lispector, já apontados no primeiro capítulo $^{97}$, são paradigmáticos dessa visão, pois Nunes entende a crítica como leitura em ação, movimento perpétuo. Interpretar, portanto, é avançar, recuar, desviar, "refazer o caminho do texto à história, sem perder a tensão que os articula”. (BARBOSA, 1986, p.XVII)

A intensa participação em congressos, colóquios, seminários o obriga a ter a consciência das diferentes linguagens críticas e a posicionar-se de maneira objetiva. Um exemplo é o comentário ao texto “As projeções do ideológico” (1975), de Luiz Costa Lima, ocorrido no $1^{\circ}$ Encontro Nacional de Professores de Literatura na PUC do Rio de Janeiro:

\begin{abstract}
O professor Luiz Costa Lima teve a gentileza de reduzir a sua comunicação de mais de 40 páginas a um resumo oral que pode caber em 20. Dessa simplificação não se beneficiou o debatedor que leu muito mais do que 40 ; leu as quatrocentas e poucas de Estruturalismo e Teoria da Literatura e as quase trezentas de A metamorfose do Silêncio. A caracterização do discurso ideológico (...) enriquece um dos núcleos conceptuais da Teoria da Literatura (...) aplicada naqueles dois livros do autor. (...) não há, a rigor, questões que possam ser consideradas independentemente do conjunto de que fazem parte. (NUNES, 1975a, p.206)
\end{abstract}

Mais adiante, completa: “(...) precisamente o interdisciplinar da Lingüística, da Antropologia e da Psicanálise - é, do trabalho de Luiz Costa Lima, a parte que mais me seduz, sem no entanto medusar-me”. (p.211)

Dentre os autores que se aproximaram do pensamento hermenêutico, em especial, o heideggeriano, destacam-se Vicente Ferreira da Silva (1916-1963), Vilem Flusser (1920-

\footnotetext{
${ }^{97}$ Cf. item I.1.7 (Carlos Drummond de Andrade), p.29-31; e item I.2.1 (Clarice Lispector), p.36-42.
} 
1991) ${ }^{98}$, Emmanuel Carneiro Leão, Eduardo Portella (1933-) e Gerd Bornheim (1929-2002). Benedito Nunes apresenta pontos de afinidades com eles, mas deles se afasta por construir sua obra em uma confrontação filosófico-literária única dentro do ensaísmo crítico.

Vicente Ferreira da Silva ${ }^{99}$ foi um intérprete agudo das cogitações heideggerianas, principalmente do chamado "último Heidegger", de quem soube compreender a necessidade de uma revisão a respeito da noção de arte.

Para Nunes (1978, p.133-4), as formulações de sua filosofia mostram mais que especulações; são meditações empreendidas como um esforço de fazer falar a linguagem; a linguagem peculiar do mito e da língua como realidades fundantes e da religiosidade como uma parte intrínseca do que é vivo. Sua arte, assim, "se origina da mesma fonte mitopoética da linguagem, revertida ao Sagrado ou ao Numinoso, matriz comum do mito e da poesia”.

A mesma preocupação mítica e mística ocuparia lugar nos textos de Vilem Flusser, que recebeu influência direta de Vicente Ferreira da Silva. Flusser, aliás, como Nunes, também colaborou no Suplemento Literário do jornal O Estado de S. Paulo.

Além da raiz heideggeriana, em seu livro Língua e Realidade (1963) ${ }^{100}$ encontra-se a concepção analítica do Tractatus Lógico-Philosophicus (1994), de Wittgenstein (1889-1951). Aos limites da linguagem, pensada pelo filósofo austríaco, Flusser transferiu, para o conjunto das línguas, os limites do mundo pensável.

Da evolução desse conjunto orgânico, que vai do não-segmentado sobre o qual o sentido se estabelece, ao vazio em que o sentido se esgota, decorre o diálogo, a conversação, que nos transpassa e move. A língua cria a realidade, mas é a poesia,

\footnotetext{
transcendendo os regimes da fala e da escrita, rompendo com a materialidade dos símbolos visuais e dos símbolos auditivos - dos quais ela depende até certo ponto, e que fornecem o substrato sensível às artes plásticas e à música - o elemento criador da língua. (NUNES, 1978, p.134)
}

A poesia, assim, próxima da filosofia, tal como na estética de Hegel, também se aproxima do indizível, que se transforma em Absoluto.

\footnotetext{
98 Vale Cf. sua autobiografia recém-reeditada no Brasil. FLUSSER, Vilém. Bondenlos: uma autobiografia filosófica. São Paulo: Annablume, 2007.

${ }^{99}$ Cf. SILVA, Vicente Ferreira da. Obras Completas. Vol.I e II. São Paulo: Instituto Brasileiro de Filosofia, 1964. A respeito desse autor Cf. JOHNS, Per. Dionísio crucificado. Rio de Janeiro: Topbooks, 2005.

${ }^{100}$ Cf. FLUSSER, V. Língua e realidade. $3^{\text {a }}$ ed. São Paulo: Annablume, 2007.
} 
Apesar da também influência heideggeriana, Emmanuel Carneiro Leão, Eduardo Portella e Gerd Bornheim não seguem a linha mitopoética adotada por Vicente Ferreira da Silva e por Vilem Flusser.

Carneiro Leão, que foi aluno de Heidegger e traduziu para o português alguns de seus textos $^{101}$, tem sido, por meio de artigos e de ensaios, grande divulgador do pensamento do filósofo alemão. Nesse sentido, é modelar seu livro Aprendendo a pensar $(1977)^{102}$. Nele se depreende a noção de poiesis, constitutiva da linguagem, que o faz buscar na filosofia grega o dizer poético e o dizer pensante, e suas reflexões sobre a crítica.

Segundo defende, “a Literatura necessita da Crítica para tomar consciência de sua existencialidade enquanto estrutura da existência”. (LEÃO, 1977, p.165) Desse modo, a Crítica se tornaria a um só tempo a "consciência existencial da Literatura como a consciência literária da existência”. A angústia do crítico se localizaria exatamente nesse ponto, pois saberia que nenhum método é capaz de apreender o literário.

Assim como Carneiro Leão, Eduardo Portella ${ }^{103}$ - que no início da sua carreira foi um dos representantes da Estilística de extração espanhola - acredita que, para se opor às explicações cientificistas da obra literária, o crítico deve recorrer à hermenêutica, entendida como aquela que "empreende o percurso inverso da modelização: vive da sua capacidade de abrir-se. (....) A hermenêutica não fala pelo texto; deixa que o texto fale”. (PORTELLA, 1974, p.53-4)

Já Gerd Bornheim vai aplicar a hermenêutica heideggeriana, em especial, em suas reflexões acerca da arte e da estética ${ }^{104}$, notadamente o teatro. Como comentado anteriormente $^{105}$, Haroldo de Campos (2003, p.11) aproxima Bornheim e Nunes como “filósofos que fazem crítica”.

Com efeito, se é presente o pensamento de Heidegger na ensaística de Nunes, como ocorre com esses autores citados, há de se ressaltar, no entanto, pelo menos dois aspectos que indicam diferenças entre eles e as reflexões do crítico paraense.

\footnotetext{
${ }^{101}$ Cf HEIDEGGER, Martin. Introdução à metafísica. $4^{\mathrm{a}}$ ed. Apresentação e Tradução de Emmanuel Carneiro Leão. Rio de Janeiro: Tempo Brasileiro, 1999; e HEIDEGGER, Martin. Sobre o humanismo. Trad. Emmanuel Carneiro Leão. Rio de Janeiro: Tempo Brasileiro, 1967.

${ }^{102}$ Cf. LEÃO, Emmanuel Carneiro. Aprendendo a pensar. Rio de Janeiro: Vozes, 1977.

${ }^{103}$ Cf. PORTELLA, Eduardo. Fundamento da investigação literária. Rio de Janeiro: Tempo Brasileiro, 1974; e Teoria da Comunicação literária. Rio de Janeiro: Tempo Brasileiro, 1976.

${ }^{104}$ Cf. BORNHEIM, GERD. Metafísica e finitude - ensaios filosóficos. Porto Alegre: Ed. Movimento, 1972; e O sentido e a máscara. São Paulo: Perspectiva, 1992.

${ }^{105}$ Cf. I.3. (Outras produções e a recepção à obra de Benedito Nunes), p.58.
} 
O primeiro aponta para a própria trajetória de Nunes como intérprete: os discursos filosóficos e literários aparecem como duas instâncias presentes na sua formação de autodidata; portanto, ele não é um literário que se ocupa da filosofia, nem um filósofo que se ocupa da literatura. Por outro lado, seu campo de interesse "não nasce nem acaba no campo da crítica literária (...). [É] também extensivo, em conjunto, à interpretação da cultura e à explicação da Natureza”. (NUNES, 2005, p.289)

O segundo aspecto é coextensivo ao primeiro: sua leitura hermenêutica, ao interrogar o texto à procura da questão que o mundo da obra sugere ao pensamento, é assentada sob o foco da interdisciplinaridade. O pensamento heideggeriano comparece, por vezes, na sua analítica, mas em diálogo com outros filósofos bem como com outras disciplinas que favoreçam a conexão.

Em síntese: Nunes, consciente dos confrontos estético-poéticos em vigência na História e na Crítica literárias, concebe uma crítica crítico-reflexiva em diálogo com eles. Diálogo que leva em conta que "refletir filosoficamente é sempre colocar o objeto sob a multiplicidade dos nexos que o sustentam”. (NUNES, 2002a, p.204)

\section{II.3. As raízes filosóficas: marcas do discurso teórico-crítico}

Se é visível a importância de Heidegger, com quem diz ter mais afinidades (NUNES, 2005, p.300), por outro lado, não se pode afirmar que o discurso teórico-crítico de Nunes é eminentemente heideggerino. Ele próprio confessou não estar sob o “efeito Heidegger”, expressão usada por Henri Meschonnic. (Cf. NUNES, 1993, p.7)

Conquanto a "prática meditante" do autor alemão exerce-lhe certo fascínio, isto não significa que outros pensadores não tenham despertado seus interesses pela relação entre filosofia e literatura. Basta assinalar que, no primeiro capítulo ${ }^{106}$, já se apontara como Nunes corrobora da explicação dada por Ricoeur a respeito do mundo do texto tornar-se texto do mundo. Questão que "é capaz de dar-nos variações imaginativas sobre o real, ou, como poderia dizer-nos Northrop Frye, enunciados hipotéticos da ação humana, reveladoras do ethos”. (NUNES, 2005, p.304)

Com efeito, a contribuição de Ricoeur aos estudos do tempo, da narrativa, da ficção, do discurso, da mímesis, bem como as suas principais reflexões a respeito da metáfora, serão

${ }^{106}$ Cf.item I.4.2. (Hermenêutica e crítica literária: o intérprete Benedito Nunes), p.95. 
reexaminados por Nunes e incorporados à sua hermenêutica. Mais adiante, voltarei a esse tema que, por ora, deixo em aberto.

Seria excessivo, no entanto, resgatar os conceitos filosóficos de cada autor com os quais Nunes construiu seu repertório de linguagem. Dentre as referências mencionadas por ele na tessitura de sua obra, os filósofos que serão destacados, aqui, obedecerão à ênfase dada a eles no seu próprio roteiro desenvolvido em “Meu caminho na crítica” (2005).

Nesse texto (p.300), Nunes comenta que Jean-Paul Sartre (1905-1980) tem, inclusive, prioridade quando se discute o vínculo literatura e filosofia, em especial porque Sartre foi, além de ensaísta, romancista e dramaturgo. Tais vertentes se estreitaram principalmente no seu Carnets de la drôle de guerre (1939-1940), diário escrito quando soldado das tropas francesas, na Segunda Guerra Mundial, à ocasião da invasão alemã, para tentar externar em conceitos abstratos, as inexplicáveis sinuosidades da experiência humana.

Como Sartre, Nunes também aprendeu a ver o mundo por meio da linguagem, já que, em sua atividade se uniram “desde novinho, e alternativamente, literatura e filosofia”. (NUNES, 2005, p.289)

A presença dessas disciplinas é igualmente um traço marcante em Nietzsche (18441900):

Em Nietzsche, a criação literária e a criação filosófica foram indispensáveis. Para Sartre, filósofo mas não poeta no sentido estrito do termo, ao contrário de seu parente espiritual germânico, as duas espécies de criação alternaram-se, partes complementares da atividade em prosa de um servo das palavras, que tentou subjugá-las, ora efetuada na forma da novela ou do drama, ora no estilo argumentativo do ensaio teórico ou do tratado filosófico. (NUNES, 1993, p.45)

A correlação literatura e filosofia, base característica da obra sartreana, já era uma tendência do pensamento francês a partir do século XVIII, no Iluminismo. Voltaire (16941778) e Diderot (1713-1784) produziam textos de natureza literária e filosófica assim como, mais tarde, Paul Valéry (1871-1945) $)^{107}$, antes de Sartre, assinalaria desse modo seus escritos.

\footnotetext{
107 Talvez Variété (1924-1945 - 5 vols. Ed. Gallimard)) seja exemplar dessa questão, por se tratar de uma coletânea dos seus principais escritos. No Brasil, seus ensaios foram organizados por João Alexandre Barbosa. Cf. VALÉRY, Paul. Variedades. Trad. Maiza Martins de Siqueira. São Paulo: Iluminuras, 1999. Por outro lado, ao se comentar de Valéry, não há como deixar de lembrar seu estudo do método de Leonardo da Vinci (Cf. Introdução ao método de Leonardo da Vinci. São Paulo: Ed. 34, 1998), que se torna base de uma metodologia heurística dos sistemas de signos que formam o universo da linguagem poética, de que não se tem um conhecimento abrangente e aprofundado. Cf. PIGNATARI, Décio. Semiótica e Literatura. São Paulo: Cultrix, 1987, p.24-33. Nunes (1978, p.130) comenta brevemente esse tema.
} 
Dos muitos artigos dedicados a Sartre, em “Do romance à razão dialética” (texto inédito - 2005) Nunes resume a importância desse autor. Recorda, assim, que a dominante intuição da existência, que dirigiu o discurso teórico de Sartre, também dirigiria a sua criação literária, a qual é, sobretudo, intuição da consciência.

O existencialismo, termo com que o filósofo chamou sua conferência ' $L$ ' existencialisme est un humanisme” (1945), será difundido, como citado anteriormente, nos seus ensaios, peças, como Les mouches (1947), e romances, como La nausée (1938). É neste que se esboça a sua filosofia, pois, enquanto o escrevia, teve contato com a Fenomenologia de Husserl. Depois da ida à Alemanha, e do conhecimento da obra Sein und Zeit (1927), de Heidegger, vai compor L'être et le néant (1943), “texto de grande envergadura argumentativa e de terminologia densa, que integra conceitos extraídos de Hegel e Heidegger, inclusive e principalmente Dasein, vertido como realidade humana”. (NUNES, 1993, p.46 - grifo do autor)

É sob a influência da náusea sartreana, como um pilar teórico, que Nunes escreverá seu primeiro estudo a respeito de Clarice Lispector - O mundo de Clarice Lispector (1966) -, base da qual, posteriormente, revisará em outros estudos da escritora, com o cuidado de primeiro examinar a linguagem, ou seja, a configuração da narrativa. Só depois, portanto, de observar essas configurações, é que, como disse, "poderia chegar a uma apreciação da filosofia, a uma concepção de mundo. (...) Foi graças a essa mediação da forma que eu consegui ultrapassar o ponto de vista muito simplificado do meu primeiro livro”. (NUNES, 2000a, p.82)

A análise fenomenológica também será apoio para a investigação do mundo poético de João Cabral de Melo Neto:

Nesse mundo de João Cabral não há nem transcendência e nem imanência. São as relações de equivalência, de inclusividade, de complementariedade, de oposição que situam os objetos numa teia verbal que se rompe em determinados pontos para refazer-se adiante, a partir de um novo centro. (...) Trata-se de um mundo mais lógico que cosmológico, e mais fenomenológico que lógico. A percepção dirige-se aos objetos sem esgotá-los. Sem atingir-lhes o núcleo, sempre referido como limite ideal da apreensão perceptiva, explora-os do ângulo específico de cada sentido. (NUNES, 1974, p.128-9) 
Pode-se destacar a importância para o estudo da literatura de L'imaginaire (1940) ${ }^{108}$ e Qu'est-ce que la littérature (1948), de Sartre, em que a natureza literária será posta em discussão ao lado da significação do seu papel social, e sobre o qual Nunes (1998, p.180) diz ser injustamente esquecido nos dias de hoje. É também nessa obra que o papel ativo do leitor, o ato concreto de leitura, é lembrado, posto ser “o objeto literário (...) um pião que só existe em movimento, o qual, começando no autor, termina no leitor”.

As idéias a propósito da linguagem que Sartre desenvolve, são acrescidas, por assim dizer, por Merleau-Ponty, na perspectiva da percepção. Assim, a linguagem passa a ser objeto de reflexão e a Filosofia e a Arte, modos de expressar o mundo: “mais do que aproximação, há contigüidade entre as duas, porquanto a Filosofia explicita a experiência humana, concretizada, em linguagens diferentes, na Literatura e na Arte”. (NUNES, 1993, p.196)

Se na La phénoménologie de la perception (1945) havia uma ligação ao Lebenswelt de Husserl e ao ser-no-mundo de Heidegger, na obra inacabada, Le visible et l'invisible (1964), Merleau-Ponty tentará manter com a ontologia deste uma conexão mais estreita, sobretudo em torno da questão da linguagem.

São tais reflexões a respeito da linguagem, notadamente a aproximação de Heidegger com Merleau-Ponty, que Nunes incorpora nos seus trabalhos, por exemplo, no ensaio "Physis, Natureza - Heidegger e Merleau-Ponty” (2004c, p.273):

\begin{abstract}
Se pretendermos iniciar uma ampla investigação sobre o que une e o que separa esses dois pensadores e, portanto, sobre as suas afinidades e incompatibilidades filosóficas, teremos que levar em conta, ao discutirmos hoje a relação do pensamento de Merleau-Ponty com a concepção do Heidegger da segunda fase, posterior à Ontologia Fundamental de Sein und Zeit (Ser e tempo), expressa na decidida convergência do filósofo francês, principalmente no seu livro póstumo, Le visible et l'invisible ( $O$ visível e o invisível), com o filósofo alemão, temos que levar em conta, dizíamos, além da ontologia heideggeriana, implícia em A fenomenologia da percepção, independentemente do mútuo influxo entre eles, o trânsito de ambos pelas mesmas disciplinas ou domínios de investigação.
\end{abstract}

É preciso ter claro, pois, que não se trata simplesmente de aplicar conceitos de um autor ao outro, mas de refletir a respeito de como esses filósofos pensaram a filosofia em vínculo com a linguagem.

O Heidegger com que Nunes dialoga é o da chamada "segunda fase”, a fase da “viragem” (Kehre), quando a interpretação dos pré-socráticos e da palavra dos poetas

\footnotetext{
${ }^{108}$ Em Por que literatura (Rio de Janeiro: Vozes, 1969), Luiz Costa Lima vai discutir, no primeiro capítulo, o significado e a função do imaginário com base nesse livro de Sartre em comparação à Phénoménologie de la perception (1945), de Merleau-Ponty.
} 
recupera o sentido da verdade como alétheia (desvelamento) e desemboca em uma História do Ser. Poetas como Hölderlin, Trakl, George e Rilke transportaram os diferentes temas literários ao tema único da essência da poesia e são

verdadeiros poetas, porque poetas da poesia, experimentaram esse diálogo [com o
ser] na atividade agonal com as palavras - "a mais inocente” (e inconseqüente) das
ocupações, a mais inócua e ineficaz, e a mais arriscada, porquanto exposta, na sua
lida não-preocupante, em seu discreto exercício lúdico, ao outro jogo perigoso do
dizer da linguagem. (NUNES, 1992, p.262)

As temáticas da linguagem, do ser e da história encontrar-se-ão, assim, conectadas com a Hermenêutica heideggereana, entretida na decifração dos textos desses poetas. Porém, Heidegger não faz uma análise da linguagem para alcançar a poesia; ele faz uma "preliminar retomada da noção de linguagem, essa mesma noção da linguagem já configurada pela poesia, pela linguagem poética, ou seja, uma linguagem afinal reconceituada poeticamente”. (NUNES, 1999, p.100)

Por certo, quando Heidegger comenta a respeito da poesia, confere a essa questão uma abrangência maior do que a referência à poesia literária; é um conceito que excede a literatura.

\begin{abstract}
A arte enquanto o pôr-em-obra-da-verdade, é Poesia. Não é apenas a criação da obra que é poética, mas também é poética a salvaguarda da obra, só que à sua maneira própria; com efeito, uma obra só é real como obra na medida em que nos livramos do nosso próprio sistema de hábitos e entramos no que é aberto pela obra, para assim trazermos a nossa essência a persistir na verdade do ente. (HEIDEGGER, 1977, p.60)
\end{abstract}

Poesia é poiesis e a Filosofia que, para Heidegger, se aproxima mais da poesia do que da ciência, é uma maneira privilegiada da linguagem que participa da poíesis. Ao unir a poesia e o pensamento, a indagação heideggereana torna-se, para Benedito Nunes (1992, p. 226), uma "prática meditante”; um novo modo de pensar e prática do pensamento: o primeiro se refere a um aspecto hermenêutico, que faz uma leitura interpretativa dos signos da essencialização em nossa época; o segundo, um aspecto prospectivo, que antevê e prepara a possibilidade de mudança ou de transformação do homem, pela retomada da reciprocidade.

Nunes, em diferentes momentos (2000a, p.87; 2005, p.301), ressalta o idioma filosófico de Heidegger; ele próprio inscrito como poético: uso de paronomásias, de neologismos etc., com destaque para o termo Dasein. No sentido denotativo, essa palavra significa existir; no vocabulário heideggereano, pode expressar tanto o homem como o aí do ser, o ente no qual se manifesta, quanto o ser aí, existente no mundo, em um movimento 
extasiado, externo - temporal. Como Dasein, o homem é temporal no fundo do seu ser. A temporalidade o auxilia a revolver o obstáculo da Metafísica, que determina o ser como ente, e a passar para o desvelamento do ser na linguagem dos poetas. Na passagem para o poético, a filosofia alcança o seu fim (Ende) ao ensinar para o homem como se habita poeticamente a Terra.

Para Vattimo (1999, p.71), a Terra "si la dimensione che nell’opera collega il mondo, come sistema di significati dispiegati e articolati, a quel suo 'altro' che è la physis, quella che com i suoi ritmi mette in moto le strutture tendenzialmente immobili dei mondi storicosociali”.

Todavia, a Terra pode ser representada também como lugar de confrontação entre mortais e imortais, que, na união de mythos e logos, é nomeado pela palavra poética. A verdade da obra, "levando a esse elemento mais recuado da physis, que permanece distante, irredutível ao mundo, corresponde, a nosso ver, ao sagrado, que os poetas buscam na época de carência do niilismo, que é também a da ‘fuga dos deuses””. (NUNES, 1993, p.19)

Nesses dizeres, Nunes já aponta a diferença entre o niilismo de Heidegger e o de Nietzsche (1844-1900) ${ }^{109}$. Para este, o acontecimento que gera a transvaloração de todos os valores é a morte do Deus hebraico-cristão. Para aquele, essa morte, ou o fato de não se poder crer no Deus cristão, demonstra uma autoridade maior da consciência e da razão.

Como observou Ernani Chaves (In: NUNES, 2000b, p.7), a interpretação heideggereana de Nietzsche espraiou-se em muitas direções e alimentou um conjunto de estudos a respeito do chamado "fim da modernidade"110.

O Nietzsche de Heidegger, de Benedito Nunes (2000c), caminha também nesse sentido. Como afirma o professor paraense (2000c, p.17): “pode-se interpretar uma filosofia guardando-se distância de seu pensamento; mas também pode o intérprete assimilar esse pensamento, fazendo-o seu”.

Heidegger interpretou Nietzsche e o integrou à sua maneira própria de pensar; Nunes também os interpretou e igualmente atribuiu-lhes novas identidades em seu discurso crítico e ensaístico.

\footnotetext{
${ }^{109}$ Para melhor estudo desta questão Cf. VATTIMO, G. Ermeneutica e nichilismo. In: La fine della modernità. Italy: Garzanti Editore, 1999, p.121-137.

${ }^{110}$ Um exemplo desses estudos é o livro de Vattimo, sobre o qual nos referimos na nota anterior. Scarlett Marton igualmente comenta essa questão. Cf. MARTON, SCARLETT. Nietzsche - das forças cósmicas aos valores humanos. São Paulo: Brasiliense, 1990, p.11-4.
} 
Para Benedito Nunes (2000c, p.18), Ser e Tempo (1927) é um “verdadeiro iceberg hermenêutico de que só emergem as pontas mais salientes, como Aristóteles, Descartes (...), Husserl, Pascal, Kierkegaard”. O Nietzsche, de As considerações extemporâneas (1873-4), aparece discutido e aproveitado a partir do parágrafo 76 da obra heideggereana.

Já em Introdução à metafísica (1935), e nos textos produzidos nos períodos de 19361940, multiplicaram-se os estudos a respeito do autor de Crepúsculo dos Ídolos (1888). Heidegger assinalava, entre outros aspectos, a íntima ligação entre a teoria da vontade de potência e a doutrina do eterno retorno. Nunes também afirma que o niilismo ativo de Nietzsche ${ }^{111}$ é, para o filósofo da Origem da obra de arte (1935), uma abertura para um novo começo do tempo e da História.

O que de fato Nunes (1993, p.14) aponta é que o

\begin{abstract}
"platonismo invertido" de Nietzsche, o sensível em lugar do supra-sensível, do "mundo verdade", será a chave, por Heidegger utilizada, para, interpretando o acabamento da Metafísica como perda do vigor do mesmo supra-sensível ou da verdade superior, fazer do niilismo o quadro epocal da gênese do nosso tempo ou da modernidade tout court.
\end{abstract}

Tal quadro do niilismo pode ser assim resumido: a devastação da terra, o exílio do indivíduo, a massificação, o totalitarismo e a fuga dos deuses. São questões que Nunes apresenta para, principalmente, discutir a questão da arte no tempo do niilismo. (Cf. NUNES, 1992, p.235-244) Questão que depois resume, para esclarecer “a passagem para o poético” no quadro do niilismo:

- um retorno à techné como poiesis, para além do arrazoamento (Gestell);

- um retorno à physis como primordial desvelamento do ser encoberto pela Metafísica;

- a experiência do pensar poético (ditchtend Denken), visando ao não-representativo no dizer da linguagem;

- o diálogo do pensamento com a Poesia. (NUNES, 1993, p.20)

O Nietzsche que Nunes destaca é o do Livro do Filósofo $(1872-1875)^{112}$, em que se revela uma filosofia à mercê de "um bando de metáforas, de metonímias, de palavras

\footnotetext{
${ }^{111}$ Cf. DELEUZE, G. Nietzshe et la philosophie. Paris, PUF, 1973. Nessa obra, Deleuze ressalta o conceito de valor e a importância do procedimento genealógico do filósofo alemão.

${ }^{112}$ Este livro é um conjunto de textos e fragmentos escritos após $A$ origem da tragédia, como parte de um projeto a respeito das origens do pensamento filosófico. A questão da metáfora aí discutida será apontada no capítulo III. Cf. III.1.2. (O mundo do texto e o processo interpretativo: a metáfora em cena), p.200.
} 
semelhantes e de repetições”. (NUNES, 2000a, p.87) Afirma que "talvez daí venha o meu grande interesse pela relação entre filosofia e poesia”.

A reflexão a respeito da linguagem também o aproxima de Wittgenstein (1889-1951), o "leitor e adepto de Tolstói, admirador de Rilke e de Trakl, [que] pôs à conta da literatura, da poesia, por excludência lógica, o que pode ser mostrado (...): a verdade essencial relativa à ação humana, a verdade do ethos de que a filosofia não pode falar”. (NUNES, 2005, p.305)

Tanto o Tractatus logico-philosophicus (1921) quanto as Investigações filosóficas (1945-9) são reinterpretados por Nunes e inseridos nas suas análises; por exemplo, em $A$ paixão segundo G. H., de Clarice Lispector ${ }^{113}$.

Wittgenstein escrevia, no fecho de seu Tractatus Lógico-Philosophicus, que devemos silenciar a respeito daquilo sobre o qual nada se pode dizer. Clarice Lispector rompe com esse dever de silêncio. $\mathrm{O}$ fracasso de sua linguagem, revertido em triunfo, redunda numa réplica espontânea ao filósofo. Podemos formular assim a réplica que ela deu: "É preciso falar daquilo que nos obriga ao silêncio". Resume-se nessa resposta o sentido existencial de sua criação literária. (NUNES, 1976, p.139)

No primeiro livro, Wittgenstein pretende articular o dizer e o pensar por meio de uma "teoria proposicional”"114, que postula um limite entre a linguagem e o mundo. Caberia à filosofia, assim, “a função de manter o pensamento, por meio de elucidações lógicas, nos limites do pensável e do dizível”. (NUNES, 2004, p.156)

Porém, nas Investigações filosóficas o filósofo austríaco retoma o questionamento acerca da linguagem em contradição com a tese logicista de uma linguagem científica buscada no Tractatus. Trata-se, agora, de procurar estudar a linguagem ordinária, cotidiana, de perceber o uso que eu faço da palavra e não o que ela significa; o que decorre daí, uma infinidade de jogos lingüísticos. É por meio da resultante dos múltiplos jogos de linguagem que constituiremos formas de vida ${ }^{115}$. A palavra “jogo” mostra a importância da práxis da linguagem; o jogo só poderá ser mostrado, nunca definido ${ }^{116}$.

\footnotetext{
${ }^{113}$ Cf. NUNES, Benedito. Linguagem e silêncio. In: O dorso do tigre. $2^{\mathrm{a}}$ ed. São Paulo: Perspectiva, 1976, p. 129-39.

${ }^{114}$ Cf. WITTGENSTEIN, L. Tractatus logico-philosophicus. Trad. Luiz H. L.dos Santos. São Paulo: Edusp, 1994, p.179-81.

${ }^{115}$ Cf. WITTGENSTEIN, L. Investigações filosóficas. Coleção Pensadores. Trad. José Carlos Bruni. São Paulo: Nova Cultural,1989, p.18.

${ }^{116}$ É pertinente lembrar que o conceito de jogo para Gadamer (2002, p.174-201) tem outra conotação. Trata-se de uma metáfora de caráter ontológico que representa a ligação entre experiência hermenêutica e experiência estética. Cf. item I.4.1 (Breves interfaces do pensamento hermenêutico), p. 83.
} 
Enfim, ao privilegiar a abordagem hermenêutica, Benedito Nunes rearticula, no seu discurso teórico-crítico, os filósofos que não só interrogaram a poesia, mas que também se interrogaram perante ela.

Dessa questão privilegiou quem optou por um "movimento de vai e vem, ora da poesia para a filosofia ora da filosofia para a poesia” (NUNES, 2000d, p.104): Sartre, MerleauPonty, Ricoeur, Nietzsche, Heidegger, Wittgenstein ${ }^{117}$...

Da sua interpretação, várias outras vozes se desprendem, além das já citadas: Foucault, Gadamer, Cassirer, Valéry, Benjamin... Vozes que permitem perceber o quanto “antropofágica”, “canibalesca” é a interpretação, pois ela "retalha, esquarteja, assimila, integra, devora, incorpora o ‘interpretado’”. (CHAVES In: NUNES, 2000c, 13-4)

\section{II.4. O perfil da linguagem crítica: $o$ traço da historicização e o uso do ensaio}

Para além das multiplicidades de pensadores que Nunes reexamina e desdobra hermeneuticamente na confecção do seu discurso, é preciso lembrar que, por outro lado, seus estudos a respeito da literatura - por ex., da poesia de Drummond, de Pessoa, de Cabral; da prosa de Clarice Lispector, da de Guimarães Rosa - põem em relevo a força pensante do literário e, por conseguinte, das relações entre filosofia e literatura.

De fato, a dimensão do literário abre perspectivas para que a obra seja explorada no seu modus operandi, no seu como, para que se possa conhecê-la, questioná-la, investigá-la na sua própria existência de "verdade” como ficção e experiência do possível. (Cf. NUNES, 1993, p.198-9)

À filosofia, portanto, restaria deixar vir à tona as potencialidades hermenêuticas do literário e, destituída de atributos tradicionais, ressaltá-las, no acompanhar dos passos iniciados por Sartre, Merleau-Ponty, Nietzsche, Heidegger, Benjamin....

É nesse sentido que Nunes aborda o confronto poesia e filosofia, apontado no capítulo anterior quando da análise da obra de Guimarães Rosa ${ }^{118}$, mas que pode ser trazido à baila, por exemplo, em textos como "Poesia e filosofia na obra de Fernando Pessoa" (1974a) e “João Cabral: filosofia e poesia” (2000f). Para Nunes (1974a, p.33)

\footnotetext{
117 A respeito de uma possível identidade entre Heidegger e Wittgenstein Cf. LEÃO, Emmanuel Carneiro. Wittgenstein e Heidegger - insensatez ou esquecimento da metafísica? In: Aprendendo a pensar. Rio de Janeiro: Vozes, 1977, p.134-6.

${ }^{118}$ Cf. I.4.3. (Literatura e Filosofia), p.99-101. e I.4.4. (Guimarães Rosa), p.101-109.
} 
Seria um erro procurar para a obra poética do grande escritor [Fernando Pessoa] uma doutrina filosófica, um sistema de pensamento interna ou externamente elaborados, ou como súmula de idéias que ela secretasse por dentro, ou como armação intuitiva e conceptual que a fundamentasse por fora. Nela o encontro e o confronto do poético e do filosófico começam a produzir-se rompendo com os moldes tradicionais, descerrando-nos um aspecto daquela situação intelectual da filosofia como obra escrita, e portanto da filosofia como gênero literário, que Paul Valéry registrou nos seus cadernos.

No poeta português, Nunes aponta o "fingimento" como o elo entre poesia e filosofia, já que este traz o problema do conhecimento, da verdade do ser, na essência da criação poética. Porém, o fingimento "interessa ao poeta enquanto poeta, isto é, enquanto agente da poiesis, que cria ou dá forma na linguagem a uma possibilidade de ser. Esta é a sua liberdade e a sua verdade”. (NUNES, 1974a, p.31)

Em Cabral, o olhar crítico de sua poesia, como o "dizer determinadas coisas de certo modo a outrem, como intencionalidade da fala ou do falante” (NUNES, 2000f, p.42), resume o aspecto fenomenológico da sua poética.

Se as relações entre poesia e filosofia são transversais, em Psicologia da composição (1947), por exemplo, - do poema em forma de uma filosofia da composição, ou de uma fenomenologia do poema -, “muito prosperam” estas relações. Isto porque, o movimento de uma busca da ascese da criação refina a linguagem até "neutralizar nela o sujeito como EU, para assegurar à mesma linguagem a comunicabilidade por meio da forma construída”. (NUNES, 2000f, p.37)

Em ambos, filosofia e poesia são reveladas, assim, no trabalho com a linguagem, na depuração crítica de uma poiesis constitutiva desses dois traços.

Nessa dialogação do filosófico com o poético, que Nunes ressalta nas suas críticas, uma de suas expressões teóricas que se sobressai é a da historicização, já apontada por JeanFrançois Nordmann (1999, p.424-5), em sua resenha acerca do Crivo de Papel (1998), como aquela que "gera uma consciência viva da relatividade, da contingência, e, mais radicalmente, da facticidade e da arbitrariedade de nossas formas de encontrar e vivenciar o mundo”.

Trata-se, pois, de conceber um sentido histórico como caminho metodológico e filosófico capaz de alargar o horizonte de suas reflexões. História entendida, como já anunciado ${ }^{119}$, como historiografia, que, ao mesmo tempo, contém vários tempos, “que não só

\footnotetext{
${ }^{119}$ Cf. item II.2 (O confronto de idéias estéticas e poéticas), p.135.
} 
circunda, mas atravessa os sujeitos fraturados ${ }^{120}$, tornando-os distintos dos sujeitos doutros tempos, sem que os faça iguais aos pertencentes ao mesmo tempo". (COSTA LIMA, 2000, p.20)

Dito de outro modo: Nunes sabe que a crítica também é uma atividade histórica por trazer, no seu discurso crítico, o debate das relações entre tempo e linguagem. Ou melhor: por realçar as tensões entre a realidade e a linguagem de sua representação; entre forma e história, concepção esta que o aproxima de João Alexandre Barbosa ${ }^{121}$.

Na defesa do círculo hermenêutico como pressuposto da interpretação, Nunes concebe que a análise literária recebe um tratamento mais adequado quando partimos de uma prévia compreensão do texto. Isto é, quando obedecemos a três aspectos necessários a toda interpretação, do qual Heidegger (2002, p.204-210) já nos apontava: Vorhabe, ter uma apreensão preliminar do que temos; Vorgriff, uma pré-concepção da nossa perspectiva interpretativa; e Vorsich, uma pré-visão de algo.

Esta descrição expõe o "tripé” que forma o círculo hermenêutico, ponto de partida da hermenêutica de Gadamer (2002), para quem esta pré-concepção é um “efeito da História”, isto é, da tradição. Tradição esta que nos aperfeiçoa e que é característica da historicidade de nosso ser; do que somos agora e que nos leverá a novas transformações.

Para Gadamer, no percurso interpretativo sempre estamos abertos à correção, que nos conduzirá à chamada “coisa do texto”. Isto é, ao interpretar, deixamos claro o entendimento que nos une à coisa interpretada dentro da situação que ocupamos e na qual estamos imersos.

Dessa forma, assumimos a nossa finitude, a nossa facticidade como ser-no-mundo limitados por objetos, em conexão com os outros, que só interpretam o que já foi compreendido antecipadamente.

Daí os nossos freqüentes “erros” históricos, quando interpretamos determinados
textos. Um exemplo trivial na literatura decorre da primeira recepção de Grande
Sertão: Veredas, em 1956. Para os críticos, quando ainda não havia conceitos
formados, o que levaria tempo - o tempo identificado ao curso do processo
interpretativo -, vigorou a pré-concepção de que o romance de Guimarães Rosa era
regionalista, tão forte para a tradição regionalista, estimulada pelo modernismo. Mas
o sertão não era o sertão localizado, regionalista. E o jagunço Riobaldo, longe de ser
um matuto, tinha a introspeçãa de um pensador (...) Como, então, falar em
regionalismo? Além do mais, podemos distinguir nessa obra certos padrões

\footnotetext{
${ }^{120}$ Para Costa Lima, o sujeito fraturado "não tem uma posição a priori definida, senão que a assume, assim se identificando, no interior dos conflitos de interesse e na assimetria dos grupos sociais”. Cf. COSTA LIMA, Luiz. Mímesis: desafio ao pensamento. Rio de Janeiro: Civilização Brasileira, p. 23-4. Cf. Também COSTA LIMA, Luiz. História. Ficção. Literatura. São Paulo: Companhia das Letras, 2006, p.139.

${ }^{121}$ Cf. BARBOSA, João Alexandre. Forma e história na crítica brasileira de 1870-1950. In: A leitura do intervalo - ensaios de crítica. São Paulo: Iluminuras, 1990, p.63-75.
} 
literários, referentes a recorrências míticas etc. Não é, portanto, de admirar que muitos se dessem mal na interpretação de Guimarães Rosa. (NUNES, 1999, p.76-7)

Além dos textos anteriormente comentados ${ }^{122}$, as relações entre tempo e linguagem são postas em evidência por Nunes quando do seu estudo da obra heideggeriana. O crítico (1992, p.144) comenta o quão ambíguo é o termo História usado por Heidegger, que tanto pode ser a "realidade histórica” (Geschichte) quanto a possível ciência dessa realidade (Historie). Aliás, essa questão será retomada, entre outros momentos, em "Experiências do tempo” (1992a), ensaio em que comenta, resumidamente, a temporalidade - condição de possibilidade do Cuidado ${ }^{123}$ e da compreensão do ser pelo Dasein -, e a problemática do pensamento heideggeriano da História.

Como sentido do Dasein, a temporalidade extrapola a experiência do tempo transferida para os processos externos da Natureza. A temporalidade “é o que se temporaliza. E não é outro senão o homem, radicalmente temporal, que por isso dentro do tempo não está, à maneira dos entes intramundanos, coisas naturais e objetos fabricados, o sujeito desse verbo”. (NUNES, 1992a, p.133)

O acontecer histórico é a representação do ser humano em seu curso de vida entre nascimento e morte, tanto na mudança quanto na permanência:

\begin{abstract}
A análise da historicidade da pre-sença [Dasein] busca mostrar que esse ente não é “temporal” porque "se encontra na história” mas, ao contrário, que ele só existe e só pode existir historicamente porque, no fundo de seu ser, é temporal. (HEIDEGGER, 2004, Parte II, p.181)
\end{abstract}

A historicidade seria a mesma temporalidade, o mesmo tempo finito, conduzido aos dois estados, individual e coletivo da existência do ser-no-mundo, que sugerem o agir e a tomada de decisões: “o homem se temporaliza, e o seu acontecer histórico é temporalização”. (NUNES, 1992a, p.133)

O tempo finito, como temporalização, Heidegger nomeia como intratemporal, de que decorre o "tempo natural", também chamado de vulgar, e ao qual incorpora o "tempo histórico".

\footnotetext{
${ }^{122}$ Cf. item II.2. (O confronto de idéias estéticas e poéticas), p.136.

${ }^{123}$ Cuidado é a "manifestação da finitite, que permite a Heidegger identificar a morte com o chegar do Dasein ao fim (...), e ver nesse ente, em sua totalidade, o ser para a morte”. (NUNES, 1992, p.117-8). O cuidado abrange, pois, três elementos que se interligam: a existencialidade, a facticidade e a queda.
} 
O histórico é o intratemporal que assume a exterioridade e a consistência das coisas reais. Quando, no entanto, Heidegger afirma que o Dasein é "histórico por ser temporal no fundo de si mesmo, ele desqualifica a história como realidade dentro do mundo, para qualificá-la (...), enquanto existência, no plano do ser-no-mundo e de seu poder-ser”. (NUNES, 1992, p.146)

Para Heidegger (2004, Parte II, p.180), o interesse cognoscitivo da Historiografia é dependente, ontologicamente, da historicidade: “é somente a partir do modo de ser da história, a historicidade, e seu enraizamento na temporalidade que se poderá concluir de que maneira a história pode se tornar objeto possível da historiografia”. (grifo do autor)

Segundo Nunes (1992a, p.138), o conceito de historicidade em Ser e Tempo é problemático:

Por um lado, visa a depurar o sentido que Dilthey emprestou, em seu Introdução às ciências do espírito (1883), à realidade histórica, enquanto objetificação de vivências. No intuito de assegurar, sem esse derivativo psicologista do desenvolvimento do Espírito em Hegel, a continuidade do que perdura de geração a geração, de período a período, de cultura a cultura, Heidegger antepôs a "silenciosa força do possível” aos fatos. Por outro lado, pretendendo evitar o escolho do subjetivismo, que resultaria da epistemologia diltheiana, concebeu a historicidade no plano da existência individual, livre na escolha de si mesma, e no plano do ser-em comum, que impõe ao Dasein a carga de uma herança ou tradição.

O crítico paraense (1992a, p.140) igualmente aponta outras carências quanto ao pensamento heideggeriano da História: quanto à função que a História teria na constituição da historicidade; e quanto à universalidade da consciência histórica.

Para ele, falta ao ser temporal do homem, na teoria de Heidegger em Ser e tempo, um "horizonte ético para a humanidade, como sujeito da História, ou a esperança de unidade da espécie humana, de que nos fala Paul Ricoeur, o que talvez seja a única universalidade histórica possível a conquistar-se nesta época de crise”. (NUNES, 1992a, p.140)

A citação de Paul Ricoeur não é gratuita. É ao autor francês que Nunes recorre para repensar a conexão entre tempo e história a fim de identificar a gênese e o declínio das idéias de "progresso" e "revolução", essenciais à consciência histórica moderna ${ }^{124}$ : “a conexão entre tempo e história [é] a nosso ver um ângulo privilegiado para acercar-nos da crise de nossa

\footnotetext{
${ }^{124}$ Cf. NUNES, Benedito. O tempo dividido: Cosmos e História. In: NUNES, B. (org.). A crise do pensamento: ciclo de preleções. Belém: UFPA, 1994, p.123-154. Este texto era originalmente intitulado "Tempo e história: introdução à crise" - Conferência no Ciclo de Preleções, Universidade Federal do Pará, junho, 1993. Foi republicado em Crivo de papel (1998, p.131-154).
} 
época, ou pelo menos, do embaraço atual do pensamento no que toca ao saber acerca do homem e de sua história”. (NUNES, 1994, p.124)

Igualmente, é com base nele que reflete a respeito do vínculo entre narrativa histórica e narrativa ficcional ${ }^{125}$ :

a questão da diferença entre narrativa histórica e narrativa ficcional redunda talvez no confronto entre as duas epistemologias mencionadas. Mas é certo que não se pode discuti-las hoje independentemente do problema mais geral das relações entre forma de pensamento e forma de linguagem, que enquadram os conceitos de Narrativa, Ficção e Ciência. (NUNES, 1988, p.11)

Antes de se comentar, porém, essa articulação no discurso de Nunes, é necessário lembrar o quanto esse tema é controverso. As relações entre História, Literatura e Ficção apontam para limites teóricos e metodológicos que estão longe de serem consensuais ${ }^{126}$.

Há de se ter claro que o próprio conceito de História sofreu inúmeras reflexões ${ }^{127}$. Se Michel Foucault (1966, p.332) aponta que a História se abre em cada domínio das Ciências Humanas, isto traz, por outro lado, a sua diluição; o que a torna proteiforme.

Para Foucault, as ciências ditas errantes - a História, a Etnologia e a Psicanálise -, são intrínsecas à dimensão hermenêutica que lhes confere um contorno topológico. A História, "que se pluraliza em Histórias, circunscreve mentalidades passadas ou constrói séries temporais graças ao tratamento sistemático de uma documentação variada, do ponto de vista do presente, que é o seu topos”. (NUNES, 2004, p.176) Assim, como discurso interpretativo, condicionada à situação hermenêutica, a História fica à mercê das relações entre o passado e o presente e das contingências de uma “fundamentação última”.

Não cabe, aqui, no entanto, fazer um levantamento exaustivo desse tema. Interessa apenas assinalar alguns pontos centrais dos liames entre a narrativa histórica e a narrativa ficcional que, de uma forma ou de outra, foram debatidos por Benedito Nunes. Ou melhor: serviram para demarcar sua posição diante das duas linguagens.

\footnotetext{
${ }^{125}$ Cf. NUNES, Benedito. Narrativa histórica e narrativa ficcional. In: RIEDEL, Dirce Côrtes (org.). Narrativa: fiç̧ão e história. Rio de Janeiro: Imago, 1988, p.9-35.

${ }^{126}$ Um dos estudos mais recentes é o de COSTA LIMA, Luiz. História. Fiç̧ão. Literatura. São Paulo: Companhia das Letras, 2006. Nesta obra, Costa Lima redimensiona a diferenciação entre os discursos da história e da literatura e concebe a ficcionalidade como "poiesis em estado puro", que "concentra-se em uma forma discursiva que retira de si a possibilidade de exercício do poder". (p.310) Para ele, "assim como a ficção não se limita à literatura (...), tampouco a literatura repousa por inteiro no ficcional”. (p.340) Bem anterior a esse livro, em Aguarrás do tempo (Rio de Janeiro: Rocco, 1989), Costa Lima já revisitava a problemática da narrativa na escrita da história e da ficção (Cf. p.15-121)

${ }^{127}$ Os estudos de Walter Benjamin a respeito deste tema, por exemplo, "Sobre o conceito de História”; "Experiência e Pobreza" e "O Narrador", atestam a importância do refletir sobre os discursos acerca da história (ou das histórias), da sua prática política e da sua ligação com a narratividade. Cf. BENJAMIN, Walter. Obras escolhidas - magia e técnica, arte e política. $3^{\mathrm{a}}$ ed. Trad. Sérgio Paulo Roauanet. Prefácio de Jeanne Marie Gagnebin (Walter Benjamin ou a história aberta). São Paulo: Brasiliense, 1987.
} 


\section{II.4.1. Contrapontos}

A polêmica acerca dessas relações tem contribuído para redimensionar a problemática entre História e Literatura. De fato, as discussões nesse campo, ora com acréscimos ora com retificações, mostram a importância de se repensar a narrativa na historiografia e de se esclarecer melhor seu vínculo com o literário.

O contar histórias, durante muito tempo, esteve associado a um cuidado com a criação da narrativa, cuidado este que aproximou o historiador aos "artifícios da retórica. Ele sabia que o seu discurso estava condenado a navegar entre 'fatos' e 'eficácias', e aí estava toda a sua arte”. (LEENHARDT, 2006, p.17)

Mais tarde, "um verdadeiro veto ao ficcional, um controle do imaginário, decorrente do racionalismo, pôde ser assistido desde meados do século XVIII, atravessando os mais variados discursos, até mesmo os artísticos”. (COSTA LIMA, 1984, p.31) A História, assim, assume um caráter mais cientificista, a responsabilidade de uma leitura crítica dos documentos, a fim de se esclarecer a verdade do passado.

O século XIX receberá esta herança que, de uma forma ou de outra, será perpetuada ${ }^{128}$. Com efeito, apesar da ambigüidade do discurso histórico que traz, em si, os procedimentos da narrativa, as últimas décadas apontam para algumas correntes que ainda concebem a História como disciplina objetiva.

Na França, por exemplo, a École des Annales ${ }^{129}$ recusava qualquer narratividade da História na busca de uma concepção científica e da integração com outras disciplinas, notadamente a incorporação das Ciências Sociais, ambicionada por, entre outros, Fernand Braudel (1902-1985) ${ }^{130}$.

A discussão das fronteiras entre as duas linguagens, no entanto, tem sido expandida em razão da natureza interdisciplinar do pensamento atual, o que acentua uma visão menos “definitiva” de conceitos, valores e o abandono de discursos de tendência hegemônica.

Desse modo, ao lado de historiadores que defendem uma experiência de investigação mais imparcial, isenta de opiniões subjetivas, outros valorizam o elemento narrativo, a

\footnotetext{
${ }^{128}$ É óbvio que a idéia de uma cientificidade, que envolvia o século XIX, não era unânime. Nietzsche, por exemplo, opunha-se ao sentido de análise histórica, pois, para ele, o passado era uma aparência; não haveria "verdades" acerca dele. Cf. WHITE, Hayden. Nietzsche: The defense of history in the metaphorical mode. In: Metahistory. The Historical Imagination in Nineteenth-Century Europe. Baltimore: The Johns Hopkins University Press, 1990.

${ }^{129}$ Cf BURKE, PETER. A Escola dos Annales: 1929-1989 - A Revolução Francesa da Historiografia. São Paulo: UNESP,1991; e REIS, José Carlos. A Escola dos Annales. Rio de Janeiro: Paz e Terra, 2000.

${ }^{130}$ Cf., por exemplo, BRAUDEL, Fernand. L'identité de la France. Paris: Arthaud, 1986.
} 
interpretação mais autoral. O historiador, tal como o romancista, também seleciona, recorta, organiza a realidade sob a sua ótica.

Essa construção da história ${ }^{131}$ é, para Collingwood (1889-1943) ${ }^{132}$, o que a aproxima com uma forma de arte, pois o profissional desta área precisa ter domínio da comunicação, da manipulação da linguagem. Selecionar e organizar, para ele, implica uma tarefa da imaginação, comum ao historiador e ao romancista.

Outros pensadores se inserem nessa linha, como Hayden White (1928-), Dominick LaCapra (1939-), Paul Veyne (1930-) e Lawrence Stone (1912-1975) ${ }^{133}$. Na dinâmica de leitura de Nunes, percebe-se que seu discurso muito de perto acompanha cada um desses autores, além de Paul Ricoeur. De forma sumária, explanar-se-á apenas as principais idéias de cada um; um realce apenas nas questões que interessam mais de perto para, depois, apresentar e comentar a concepção do crítico paraense acerca do tema.

Segundo Hayden White, o relato historiográfico incorpora modelos da narrativa literária como uma espécie de ficção verbal, como afirma em Tropics of discourse. Essays in Cultural Criticism (1978) ${ }^{134}$. Sem sentir a “necessidade de se indagar sobre ficção” (COSTA LIMA, 2006, p.18), obedece a uma tipologia do enredo (emploment) historiográfico baseada na Anatomy of Cristicism (1954), de Northrop Frye (1912-1991) - o romanesco, o trágico, o cômico, o satírico - e completada por uma Tropologia (metáfora, metonímia, sinédoque e ironia).

O que White propõe é mostrar que o historiador deve ter liberdade para ler os documentos e descrevê-los em uma estrutura narrativa cuja construção permita, inclusive, demarcar as especificidades de cada profissional, já que a forma como utilizaram a linguagem assinala, por assim dizer, sua criação historiográfica.

Não se trata, todavia, de estabelecer uma identidade entre a literatura e a história. Entre elas há uma diferença de grau. A história utilizaria as ficções como meios de conseguir atingir os eventos reais. Dito de outra forma: a narrativa histórica trataria os eventos reais por meio das formas ficcionais em vigor em uma cultura.

\footnotetext{
${ }^{131}$ Segundo Bebiano, o H maiúsculo se refere à pretensa cientificidade da História. Sem esse sentido, adota-se o h minúsculo. Cf. BEBIANO, Rui. Sobre a história como poética. In: D’ENCARNAÇÃO, José (coord.). As oficinas da História. Lisboa: Colibri - Faculdade de Letras da Universidade de Coimbra, 2000, p.47.

${ }^{132}$ Cf. COLLINGWOOD, R.G. The idea of history. Oxford: Clarendon Press, 1946.

${ }^{133}$ Para um estudo aprofundado desses autores Cf. BEBIANO, Rui. Sobre a história como poética. In: D’ENCARNAÇÃO, José (coord.). As oficinas da História. Lisboa: Colibri - Faculdade de Letras da Universidade de Coimbra, 2000, p.47-70.

${ }^{134}$ Cf. WHITE, Hayden. Tropics of discourse. Baltimore: The Johns Hopkins University Press, 1978.
} 
Para ele, a separação entre fato e ficção foi superada pelo próprio modernismo literário:

Aquilo que vemos na crítica moderna e na ficção das vanguardas é que a distinção entre fato e ficção não pode ser facilmente mantida quando se trata de escrever sobre aspectos da realidade situados no passado (...). [O passado é] uma construção feita pela própria escrita ${ }^{135}$.

Dominick LaCapra também defende uma dimensão literária na escrita da história. O simbólico, o pensamento abstrato, o enunciado subjetivo são igualmente aceitos, ao lado de White, como construtores da narrativa histórica ${ }^{136}$.

No entanto, LaCapra discorda em alguns aspectos com ele. O primeiro é a crítica à tipologia de White, considerada um modelo “cientificista”" ${ }^{37}$. De igual modo, rejeita a idéia de criatividade na escrita da história, pois considera que as noções de ordem devem ser respeitadas, bem como avalia ser essencial o historiador ter um conhecimento preciso dos fatos para construir a história dos textos. Nesse sentido, sugere um método da história que permita difundir a complexidade do real descrito, sem volteios criativos e sem deixar de tocar nas distinções conceituais e analíticas.

Embora LaCapra não compartilhe da imagem de "historiador-poético" proposta por White, pondera, no entanto, que o historiador deva aprender com os romancistas os domínios da linguagem.

Tal concepção é corroborada por Paul Veyne ${ }^{138}$, que reafirma a importância da trama e do enredo na construção da narrativa histórica, assim como do conceito de intriga, próprio da ficção, para uma maior compreensão dos fatos.

Lawrence Stone ${ }^{139}$ reascende a discussão em uma crítica direta aos historiadores positivistas, como Ranke (1795-1886), e se empenha em defender a volta à narrativa como retomada de uma tradição:

a história terá deixado de se aceitar a si própria como narrativa, tornando-se essencialmente analítica, no momento em que, desinteressando-se de saber “o que” e “como" foi ou aconteceu - perguntas que apelam à narração - passou a ocupar-se de explicar "porque” é que isto ou aquilo foi ou aconteceu. São dois modos, duas

\footnotetext{
${ }^{135}$ Cf. WHITE, Hayden. Entrevista. In: Folha de S. Paulo. Caderno Mais! 11de setembro de 1994, p.5.

136 Cf. LACAPRA, Dominick. Rethinking intellectal History: texts, contexts, languages. Ithaca: Cornell University Press, 1983.

${ }^{137}$ Cf. COSTA LIMA, Luiz. História. Ficção. Literatura. São Paulo: Companhia das Letras, 2006, p.19.

138 Cf. VEYNE, Paul. Como se escreve a história: Foucault revoluciona a história. Trad. Alda Baltar e Maria A.Kneipp. Brasília: Editora da Universidade de Brasília, 1982.

${ }^{139}$ Cf. STONE Lawrence. The revival of narrative: reflections on a new old history. In: The Past and The Present Revisited. London-New YorK: Rotledge \& Kegan Paul,1987.
} 
formas distintas e na sua opinião antagônicas de fazer a história. O historiador [Stone], vindo da segunda, aceita que continue a existir quem opte por ela, mas escolhe agora muito claramente a primeira. (BEBIANO, 2000, p.60)

Pode-se lembrar, ainda no quadro de debates acerca desse tema, a contribuição de Roland Barthes (1915-1980), que, em O rumor da língua (1888, p.145-57) ${ }^{140}$, reflete a respeito do discurso de alguns historiadores clássicos, como Heródoto, Maquiavel, Bossuet e Michelet. Em síntese, Barthes afirma que a importância da história, como discurso, depende do "real concreto", compreendido pelos historiadores e pela literatura realista, como independente do sentido proferido pela linguagem:

A história (o discurso histórico: história rerum gestarum) é o modelo dessas
narrativas que admitem preencher os interstícios de suas funções com notações
estruturalmente supérfluas, e é lógico que o realismo literário tenha sido, com
algumas décadas de aproximação, contemporâneo do reinado da história “objetiva”.
(p.163)

Como se percebe, ainda que de modo simplista e esquemático, esta apresentação dos autores tem o mérito de pôr em foco uma problemática a se considerar: ao se discutir os conceitos de narrativa, de história, de literatura, de ficção - isto é, os limites entre os campos disciplinares -, é a questão da metáfora, que subjaz em cada um dos domínios descritos, o ponto de relevância. Ou melhor, o modo como ela é concebida; concepção esta que merece uma maior investigação, efetivada mais adiante.

Sem dúvida, a posição de Paul Ricoeur, que dialoga direta ou indiretamente com os autores elencados, é a que mais se aproxima da de Nunes, embora ele atribua, nas suas conclusões, uma cientificidade menor do que a do filósofo francês.

No texto "Narrativa histórica e narrativa ficcional” (1988), Benedito Nunes parte das seguintes indagações: "Como entra o tempo na Teoria da narrativa? Como entra a narrativa na Teoria da História? Como História e Ficção se interpenetram?” (p.12) Em seguida, expõe como Ricoeur responde a essas questões, com base em Métaphore vive (1975) ${ }^{141}$ e Temps et récit (1983) para, depois, comentá-las. Cabe notar que esses livros foram produzidos conjuntamente e ambos referem-se à questão central de inovação semântica. Tal inovação só ocorre no discurso, ou seja, nos atos de linguagem de extensão igual ou superior à frase.

Ricoeur recorre às Confissões de Santo Agostinho e à Poética de Aristóteles para abalizar a reciprocidade entre narratividade e temporalidade, na confrontação entre

\footnotetext{
${ }^{140}$ Cf. também acerca da narrativa BARTHES, R. Introdução à análise estrutural da narrativa. In: BARTHES, R. et al. Análise estrutural da narrativa. Trad. Maria Zélia B. Pinto. Rio de Janeiro: Vozes, 1971, p.18-58.

${ }^{141}$ Retomarei o comentário a respeito desse livro no próximo capítulo.
} 
concordância e discordância das análises do tempo, de Agostinho, e da intriga, de Aristóteles. (RICOEUR, 1893, p.18)

Dessas análises, concebeu um terceiro sentido de tempo, o tempo histórico, que não seria nem o tempo cósmico e nem o real, mas aquele que se constrói como narrativa, mediado por conectores: o calendário, a seqüência de gerações, os arquivos, os documentos e o traço. Só podemos entendê-lo por meio dessas analogias.

O discurso histórico, posto que se sustenta com base no tempo e este só pode enunciarse por meio do modo do "como”, da analogia, tem a condição de seu saber localizado entre a ontologia e a retórica, por conseqüência, entre ser e não-ser. É esta condição paradoxal do ser-como, que possibilita que a narrativa histórica se aproxime da ficção:

(...) nem completamente singular, nem inteligível apenas como ato do indivíduo, porque integra a rede dos efeitos involuntários e impessoais da ação, o fato histórico recebe o perfil analógico de um quase-acontecimento, que o emparelha com o quase-enredo e com o quase-personagem. São essas três amarras (...), que mantêm a História ligada à narrativa, com a qual não pode romper inteiramente. (NUNES, 1988, p.28-9)

E não pode romper-se, por causa da ação, que envolve agentes, fins, circunstâncias, interações e resultados voluntários e involuntários. Ou porque, “optando por dizer a verdade do que foi, a história não se desvencilha, radicalmente, do que poderia ter sido”. (COSTA LIMA, 2006, p.385)

Por certo, Ricoeur distingue três fases na operação histórica: a "fase documental”, que leva à organização de documentos, provas etc.; a “fase explicativa/compreensiva”, a busca dos porquês; e a “fase representativa”, em que se trabalha o discurso histórico.

Porém, entre o historiador e a realidade "não mais existente, que deixou de ser, a relação, nem de completo distanciamento nem de coincidência, só pode ser analógica, de caráter metafórico, o que é compatível com o plano configurativo da narrativa”. (NUNES, 1988, p.33)

O historiador precisa saber narrar uma história, já que esta é uma forma de narrativa; mas, por outro lado, é também uma ciência que solicita uma argumentação, provas, evidências.

Só se conhece o que já foi, portanto, por meio de documentos, ao requerer da imaginação as suas faculdades tropológicas; o historiador, dessa forma, reconstrói aquela 
realidade como figuração. No embate com o efeito da figuração do passado, a leitura "reconfigura” (transforma, ressimboliza) este passado atualizado pela ficção: A leitura, portanto, ficcionaliza a História. Em contrapartida, a leitura historiciza a
Ficção, na medida em que a voz narrativa situa no passado o mundo da obra. (...) É,
pois, na refiguração do tempo que a narrativa histórica e a narrativa ficcional se
interpenetram, sem se confundirem. (NUNES, 1988, p.34)

História e ficção, assim, estariam unidas pela maneira como elaboram a temporalidade. O tempo entra na teoria da narrativa pelo discurso, pelos atos de linguagem e é elaborado de acordo com a dimensão do enredo, dependente da compreensão narrativa, por sua vez, dependente da "inteligibilidade prática”. O tempo decorre da dimensão intratemporal da existência humana, o que acarreta a natureza circular do nexo recíproco entre narratividade e temporalidade: a articulação narrativa do tempo é condicionada à experiência temporal prévia.

Essa articulação da experiência temporal já se encontra delineada no "mundo-davida”, onde as duas narrativas se entrecruzam:

\begin{abstract}
A titre ultime, l'histoire ne peut rompre tout à fait avec le récit, parce qu'elle ne peut rompre avec l'action qui implique des agents, de buts, des circonstances, des interactions et des résultats voulus et non voulus. Or l'intrigue est l'unité narrative de base qui compose ces ingrédients hétérogènes dans une totalité intelligible. (RICOEUR, 1986, p.18)
\end{abstract}

A mediação entre o tempo e a narrativa é feita por meio da mímesis, que Ricoeur denomina mímesis I (pré-figuração), mímesis II (configuração) e mímesis III (refiguração). Para ele, a mímesis II é o ponto central da análise; “par as fonction de coupure, elle ouvre le monde de la composition poétique et institue, comme je l'ai déjà suggéré, la littérarité de l' oeuvre littéraire’’. (RICOEUR, 1983, p.86) No entanto, Ricoeur não se fixa apenas nela, posto que alarga seu estudo ao considerar a configuração (mímesis II) em sua função de mediação entre a perfiguração da ação e sua refiguração pela transmissão da obra.

A mímesis I abrange um grupo de conjecturas necessário para a possibilidade de construção do enredo, da história, e que se fundamenta na "pré-compreensão" do mundo da ação prática. Apresenta-se sob três traços: a) estruturais - a capacidade de conhecer e identificar previamente a ação por seus aspectos estruturais; b) simbólicos - a competência em perceber as mediações simbólicas da ação em diversos núcleos sociais e culturais; e c) temporais - o caráter temporal da ação é de onde ocorre a capacidade da ação a ser narrada. 
A mímesis II é a constituição da própria atividade narrativa, a composição do enredo, da intriga que, por sua vez, faz a intermediação entre os acontecimentos individuais e uma história que se compõe de fatores heterogêneos como agentes, fins, meios, interações, circunstâncias etc. A mímesis II leva à mímesis III, que é o ponto de encontro entre o mundo do texto e o mundo do leitor, ao mostrar que é a ação de leitura que completa o texto.

A definição sugerida por Ricoeur da mímesis III resgata a sua leitura a respeito da metáfora $^{142}$ e faz uma aproximação com o sentido da fusão de horizonte, de Gadamer ${ }^{143}$. Com relação à metáfora, argumenta que o leitor recebe do texto não só o sentido da obra, mas, por meio dele, a sua referência. Tal referência traz à linguagem uma experiência reveladora do mundo do texto e de sua temporalidade.

A hermenêutica que Nunes faz ao texto de Ricoeur, do qual esboçamos alguns conceitos, pode ser resumida pelos seguintes contrapontos à teoria do pensador francês: Nunes amplia a questão da ficcionalidade do narrativo às formas de linguagem - e não só ao romance, como postula Ricoeur. Também quando se refere à História, a entende como Historiografia, pois acha que "não podemos designar um lugar certo para a História, pois ela sempre dependerá de uma experiência prévia, visto que tem como precedentes a historicidade: seja a posição do historiador, seja a intimação do presente, da época”. (NUNES, 1988, p.55)

O discurso do historiador é, portanto, para ele, um discurso de justificação; não analítico-dedutivo, mas de conclusões prováveis.

Em outro momento, ao responder a respeito do conceito de utopia para descrever sua visão do futuro da sociedade humana, Nunes, com base em Idéia de uma história universal do ponto de vista cosmopolita (1784), de Kant, reformula a idéia de uma unidade e desenvolvimento histórico:

Kant não tem a pretensão de fundar a história. Mas o ponto de vista kantiano, que critica a metafísica, é o ponto da vista da finitude, ou seja, a comunidade do direito, o fato de não tomar o homem como meio, mas sempre como fim. (...) Temos de ter uma conversão da humanidade pela história. Nós podemos revolucionar a concepção que o homem tem de si mesmo, não podemos revolucionar a sua vida, de tal modo que pudesse haver uma conversão. (NUNES, 2000a, p.88)

\footnotetext{
${ }^{142}$ Cf. especialmente o capítulo VII de La Métaphore vive (1975, p.273-321). A concepção de metáfora para Ricoeur será discutida no terceiro capítulo.

${ }^{143}$ Cf. item I.4.1.(Breves interfaces do pensamento hermenêutico), p. 82.
} 


\title{
II.4.2. Exercício de reflexão: o uso do ensaio
}

A historicização que Benedito Nunes traz na confecção da sua escrita é um dos traços pessoais da sua reflexão. Trata-se não apenas da preocupação da História como tema - em conexão com o tempo ou a linguagem - como comentada há pouco. Trata-se, também, da historiografia como reinscrita incorporada ao seu texto.

\begin{abstract}
Diante do texto literário, o crítico-leitor passa a examiná-lo sempre de acordo com uma perspectiva avaliadora mais ampla, que a experiência da época ou da sociedade em que vive já lhe propõe, de antemão na linguagem de todos, como fala comum. Mas dá-se que o próprio autor também se lê. Como crítico-leitor de si mesmo, pode ler-se indagando seu texto diante da instância epocal que lhe prejulga a obra literária ou recapitulando-a diante da concepção filosófica que a ela integrou. (NUNES, 2005, p.292)
\end{abstract}

De fato, poucos autores têm, como característica de linguagem, o uso recorrente da busca do contexto do passado, ou repetidos cortes sincrônicos para revelar nuances, ou uma descrição pormenorizada de detalhes que ajudam a compor a análise.

Assim, é possível encontrar no seu discurso diferentes quebras que avisam desses aspectos. Eis alguns exemplos escolhidos aleatoriamente:

- $\quad$ "Recapitulemos os pontos em comum compartilhados pelos dois pensadores [Heidegger e Sartre] com seus respectivos enfoques interpretativos”. (NUNES, 2005 [texto inédito], p.2);

- “Falarei dos críticos lidos por mim no passado e no presente com mais freqüência, e que me são familiares; o recorte histórico adiante traçado é, portanto, o roteiro de uma experiência pessoal da literatura, privilegiando a poesia”. (NUNES, 2000, p.54);

- CComo vasto é o tema e diminuto o tempo disponível para uma exposição em ordem histórica ou sistemática, arrogo-me o direito de uma apresentação descontínua, episódica, de que cada fragmento, à maneira de um cenário, constitui um caso exemplar”. (NUNES, 1998, p.10)

Se esse senso histórico, às vezes, não facilita o entendimento, ou se estrutura como uma narração superficial ainda que minuciosa; por outro lado, a perspectiva histórica ajuda o leitor a situar-se ou, antes, o incentiva a uma maior pesquisa do assunto tratado.

Por certo, na ensaística de Nunes o interesse para com o sentido histórico é diferente do historicismo buscado por Dilthey ${ }^{144}$. Trata-se, antes, de procurar a referência do texto, que

${ }^{144}$ Cf. item I.4.1. (Breves interfaces do pensamento hermenêutico), p.76-7. 
se abre aos sentidos, à historicidade da experiência humana, que se encontra na "comunicação na e pela distância”. (RICOEUR, 1990, p.44)

De qualquer modo, o procedimento da historicização vem acompanhado de uma consciência do fazer textual que se efetua, muitas vezes, por meio do ensaio.

Ensaio como forma, importante esclarecer, em uma concepção próxima à sugerida por Adorno $^{145}$, em que o texto se constrói como escrita de horizonte, aberta, de natureza transitória, sem uma construção dedutiva ou indutiva.

O ensaio é aberto, como explica Adorno (2003, p.37), porque "nega qualquer sistemática, satisfazendo a si mesmo quanto mais rigorosamente sustenta essa negação”. De modo inverso, igualmente apresenta-se fechado, pois se delineia pela exposição.

Tal exposição se faz em tensão com o exposto, com a renúncia de pensar pronto, já que é própria do ensaio a experimentação, o embate com o objeto, a reflexão que não quer se esgotar. Por isso o ensaio é inconclusivo; por isso Benedito Nunes (1993, p.79) diz em um de seus textos: “(...) as indagações finais desse trabalho inconclusivo, propostas a título de pretexto para discussão". Ou "Esta é uma conclusão inconclusiva com a qual encerramos esta obra”. (1999, p.160)

No ensaio, os conceitos e as teorias são externos, mas ele os questiona e os confronta, posto que "continua sendo o que foi desde o início, a forma crítica par excellence". (ADORNO, 2003, p.38)

A ensaística de Nunes revela essa procura de uma linguagem de tentativa, tateante, linguagem de pressupostos “com tudo aquilo que nós podemos na leitura hermenêutica reduzir (...). Faz-se ensaio na pressuposição do grande espetáculo acabado, do que se pretenda venha a ser uma apoteose”. (NUNES, 1988, p.118)

É pertinente lembrar que ensaio vem do latim exagìum ì,i, “ato de pesar, por extensão, ponderar, avaliar”. Dessa forma, o ensaio é mais próximo do discurso filosófico, conquanto Nascimento (2004, p.55) o define como "forma discursiva limítrofe entre a literatura e a filosofia”, uma vez que “o pensamento, o ato e o fato de pensar (...) pode ocorrer independentemente da literatura e da filosofia, no contato com a alteridade, a qual atravessa, estruturando, o sujeito que pensa”.

\footnotetext{
${ }^{145}$ Cf. ADORNO, T.W. O ensaio como forma. In: Notas de literatura I. Trad. Jorge de Almeida. São Paulo: Duas Cidades/Ed.34, 2003, p.15-45.
} 
Literatura e a filosofia são domínios que se entrecruzam no ensaio de Nunes como exercício reflexivo de uma escrita que se desdobra, tal qual a de Ricoeur, em um "cipoal de citações e interpretações de vários autores”. (NUNES, 1988, p.51) Ensaística plural cuja prática se fundamenta em expor a leitura hermenêutica em permanente dialogação, de forma fluente, mas, ao mesmo tempo, analítica e desafiadora. 
“Nenhuma outra arte é capaz de comunicar, como a literatura, o moralmente insuportável, a crueldade, a barbárie social e política”. 
CAPÍTULO III

A opacidade crítica: a linguagem na divisa entre o conceitual e a criação de imagens

Ao longo da leitura de (com) Benedito Nunes, algumas questões da sua construção crítica foram postas em destaque: 
1. a leitura hermenêutica, pensada como tradução, para o discurso reflexivo, do discurso dos textos literários, do seu modus operandi, do seu como, pronunciador da “'verdade da obra’, de que nos fala Walter Benjamin ('As afinidades eletivas de Goethe'), a busca de sua verdade como ficção, [que] legitimaria a preocupação filosófica dessa crítica” (NUNES, 1993, p.198);

2. a investigação filosófica de uma obra literária compreendida como forma e examinada por meio de três aspectos: a) a linguagem; b) as conexões da obra com as tendências do pensamento histórico-filosófico; e c) as idéias que são problemas do e para o pensamento;

3. a crítica que nasce da tensão provocada pela linguagem literária, empenhada em realçar o poético e pensar a respeito dele;

4. a postura de crítico consciente dos confrontos estético-poéticos em vigência na História e na Crítica literárias;

5. a exposição que reexamina e desdobra hermeneuticamente vozes de filósofos que não só interrogaram a poesia, mas também se interrogaram diante dela;

6. a linguagem crítica marcada pela historicização e pelo uso do ensaio.

Uma vez alinhavadas essas observações gerais, torna-se possível, agora, abordar como se constrói a sua expressão ensaística. Isto porque, em um trabalho que pretende sistematizar e realçar a sua atividade crítica, a linguagem, ou melhor, a maneira como tece essa linguagem crítica, merece um relevo especial.

Tal preocupação é decorrente do próprio processo de leitura que alicerça toda a crítica:

Faço a apologia da crítica como ato permanente e renovada leitura (...) O crítico, já se afirmou, é um multileitor, não só porque lê os textos muitas vezes, mas porque, em cada leitura efetuada em momentos diferentes, redescobre-os, reinventa-os, de acordo com as circunstâncias culturais e históricas que possibilitam a sua compreensão. (NUNES, 1998, p.261-2)

Desse modo, torna-se necessário discutir como ocorre a relação entre o discurso crítico e o seu objeto de estudo, no caso, o texto literário. O modo como Benedito Nunes organiza sua linguagem reflete a preocupação com o leitor e de como este, na dinâmica hermenêutica, pode estabelecer a confrontação com seu pensamento. 
Neste sentido, já foi considerado "um escritor-filósofo”, expressão sobre a qual José Castello ${ }^{1}$ lhe perguntou se concordava:

Não sei se sou filósofo. Talvez não passe de um professor de filosofia aposentado.
Mas procuro ser um bom escritor, preocupação que me foi incutida por Mário
Faustino. Luto contra o mais grave pecado dos escritores: a inexatidão, que
Fernando Pessoa combateu. Não posso melhorar o que escrevo empregando à risca
os jargões do dia. Com o veso da pedanteria, isso só pode conduzir ao estilo
administrativo da maioria das teses universitárias. Se o idioma filosófico tem o seu
vocabulário, vamos empregá-lo com clareza. Quanto melhor a forma de linguagem,
maiores são a exatidão e a clareza do pensamento, mesmo quando complexo e
obscuro. Não se deve sacrificar a complexidade; dobre-se-a pela escrita maleável,
sem ornamentos, mas bem temperada pelas claves sonoras e rítmicas da língua
portuguesa.

No seu idioma crítico, as marcas da reflexão filosófica são aplainadas de modo que a sentença seja inteligível e estabeleça um diálogo com o mundo do leitor: A idéia platônica de exílio terreno, e do retorno da alma ao seu lugar originário, foi
o plano de fundo místico em que se projetou a experiência da morte na poesia de
Fernando Pessoa. (...)
Carlos Drummond, “poeta do finito e da matéria”, que a esse respeito passou por
uma aprendizagem que se poderia qualificar de montaigniana, dar-nos-á (....) lição
semelhante, que o distancia de Fernando Pessoa e o aproxima de Tristan Corbière e
Jules Laforgue. (NUNES, 2002/2003, p.19/21- grifo meu)

Basicamente, não se encontra no seu tecido ensaístico uma adjetivação excessiva, mas, de forma discreta, as qualificações aparecem de forma pontual:

- "Essa mudança de status não consegue porém levar a narrativa ao cerne da fecunda École des Annales”. (NUNES, 2004, p.206 - grifo meu)

- “Os temas apontados, soberanamente filosóficos, acusam o caráter desse jogo (...), revelando o teor da alta singularidade literária alcançada por Juliano Garcia Pessanha em Sabedoria do Nunca”. (NUNES, 1999c, p.15 - grifo meu)

- “Os Quartetos [de Eliot] harmonizam diferentes atitudes e formas de pensamento. (...) Daí o admirável sentido universalista desses poemas, como busca da eternidade no fluxo do tempo”. (NUNES, 2005a, p.279 - grifo meu)

Na procura de se expressar melhor, o seu modus operandi, o "como" da sua construção textual se efetua basicamente por meio de parágrafos extensos, cujo ritmo recupera ou tenta recobrar o tom de oralidade.

\footnotetext{
${ }^{1}$ Cf. Entrevista a José Castello. In: O Estado de S. Paulo, Caderno 2, 28 de fevereiro de 1998, p.8.
} 
Sob este ângulo, há o adiamento do ponto final e um comentário se desdobra em outro, que se intercala com uma referência ou citação, até se “fechar” coerentemente:

\begin{abstract}
Não há dúvida que a idéia, o fundo metafísico da lamentação patética nos dois diálogos, remonta ao mesmo conflito da vontade individual com a vontade universal, dramatizado, no século XIX, pela filosofia pessimista de Schopenhauer, que uniu a doutrina budista de Maya, da ilusão da vida, como perpetuidade do sofrimento, à interpretação gnoseológica da oposição kantiana entre fenômeno, tomado no sentido de objeto de conhecimento empírico, ilusório, parcial, e o número, coisa em si, encarnação da vontade universal, objeto de intuição afetiva, identificadora do sujeito e não de representação conceptual. (NUNES, 1993, p.141 [comentário acerca do capítulo “O delírio" de Memórias póstumas de Brás Cubas, de Machado do Assis])
\end{abstract}

Nessa espécie de diálogo, ou melhor, de dialogação ${ }^{2}$, o crítico e o leitor se encontram nos jogos de linguagem, nos jogos semânticos, sonoros, às vezes paronomásicos (tal como a linguagem heideggeriana), impressos no texto:

O que prevalece na forma do discurso narrativo machadiano é o tom dubitativo - a esquiva e equívoca maneira de narrar, reticente e desconfiada, que também pode ser enganadora e enganosa, pondo em causa a própria capacidade de representação da realidade. (NUNES, 1993, p.138 - grifo meu)

Por certo, há uma espécie de criação poética, um discurso em construção, mas a linguagem de Nunes, no trato interpretativo das obras, na crítica que efetua o diálogo literatura e filosofia, se equilibra no intervalo entre essas criações e o conceitual. Uma crítica em que a principal característica é a opacidade, a idéia de que há um fio, um espaço nãotransparente, entre a crítica e o poético.

Há talvez, porém, um questionar de fronteiras. Entretanto, há também, sem dúvida, uma crítica instigante, que permite um repensar dessas questões; ou melhor, da questão da metáfora, posto que "nos estudos sobre limites entre áreas, limites de contigüidades entre áreas, dizem respeito à concepção usual de metáfora como ornamentalidade”. (COSTA LIMA In: NUNES, 1988, p.52)

A maneira como Nunes trabalha com a seleção lexical é um exemplo disso. Percebe-se claramente que o vocabulário escolhido é alusivo ao texto-objeto analisado. Assim, em cada crítica temos palavras do autor abordado, que são reintegradas, metaforicamente, ao seu modo de escrita. É claro que estamos diante de uma intertextualidade crítica ${ }^{3}$, mas não perante aquela intertextualidade da crítica-escritura barthesiana. Isto porque,

\footnotetext{
${ }^{2}$ Para Nunes (1998, p.162), a dialogação é "o estar um diante do outro da conversa, daqueles que se interrogam, confrontados a si mesmos e ao mundo, a moralidade do pensamento em situação. A dialogação é, ainda, o inquieto movimento do pensar vivido".

${ }^{3}$ A respeito da intertextualidade crítica Cf. PERRONE-MOISÉS, Leyla. Crítica e Intertextualidade. In: Texto, Crítica, Escritura. São Paulo: Ática, 1978, p.58-76. Para Eco (2000, p.128), “a metáfora obriga a que nos
} 
só a crítica-escritura pode ser um discurso verdadeiramente intertextual. Nela, não se trata de recobrir explicitando, mas de recobrir ambigüizando (isto é a disseminação, isto é a significância). O novo texto terá as mesmas caracterísitcas de densidade sêmica, de suspensão, de sentido, de fundamental ambigüidade e de abertura escritural que são as do texto poético. (PERRONE-MOISÉS, 1978, p.70-1 - grifo da autora)

Desse modo, se há, no discurso de Nunes, um diálogo com o texto analisado, isto não significa que há quebra de divisas, que seu discurso assuma as mesmas relações sensoriais, pictóricas, ambigüizadoras do poético. Percebe-se, sem dúvida, uma incorporação; no entanto, mesmo assim seu escrito conserva características da crítica ensaística, reveladora do poético, sem que se torne, ela própria, poética:

Viver - não é? - muito perigoso. Porque ainda não se sabe. Por que aprender a viver é que é o viver mesmo (...) Eu atravesso as coisas - e no meio da travessia não vejo - só estava era entretido na idéia dos lugares de saída e de chegada. (ROSA, 1986, p.38)

(...) a viagem redonda, a travessia das coisas, - que é vivência e descoberta do mundo e de nós mesmos, nessa aprendizagem da vida, em que o próprio viver consiste - a viagem-travessia que se transvive na lembrança, constitui o saldo imponderável das ações, que a memória e a imaginação juntas recriam. (NUNES, 1976, p.175)

Esse exemplo, de uma crítica ao texto Grande Sertão: veredas (1986), de Guimarães Rosa, mostra que a incursão ao metafórico é a maneira como Nunes opera com os elementos constitutivos da obra analisada - os tropos e as figuras, a seleção lexical e a semântica, os componentes fonológicos, os morfológicos e os sintáticos. Isto é, a sua capacidade de articular esses aspectos e as possibilidades de uma leitura atenta a percorrer os espaços, as entrelinhas que a palavra poética lança cheia de significações. Estas são retomadas, assim, no jogo de linguagem e na busca por um processo de realce do texto investigado:

\begin{tabular}{|l|l|}
\hline \multicolumn{1}{|c|}{ Guimarães Rosa } & \multicolumn{1}{c|}{ Leitura crítica de Benedito Nunes } \\
\hline $\begin{array}{l}\text { Por que aprender a viver é que é o viver } \\
\text { mesmo }\end{array}$ & $\begin{array}{l}\text { Vivência e descoberta do mundo e de nós } \\
\text { mesmos, nessa aprendizagem da vida }\end{array}$ \\
\hline Eu atravesso as coisas & a viagem redonda, a travessia das coisas \\
\hline e no meio da travessia não vejo & Transvive na lembrança, \\
\hline $\begin{array}{l}\text { só estava era entretido na idéia dos lugares } \\
\text { de saída e de chegada. }\end{array}$ & $\begin{array}{l}\text { A viagem-travessia que se constitui o saldo } \\
\text { imponderável das ações, que a memória e a } \\
\text { imaginação juntas recriam }\end{array}$ \\
\hline
\end{tabular}

interroguemos sobre o universo de intertextualidade e, ao mesmo tempo, torna ambíguo e multiinterpretável o contexto. E da intertextualidade também fazem parte as metáforas precedentes, de tal sorte que podem ocorrer metáforas de metáforas - interpretáveis apenas e tão-somente à luz de um suficiente conhecimento intertextual”. 
A leitura que nasce daí oferece desdobramentos singulares: ao comentar os significantes de uma obra, Nunes redescobre diferentes sentidos destes mesmos significantes, em uma pluralidade hermenêutica, projetiva. Uma leitura de horizonte, de um olhar salteante para além da linha da imagem, para o solo metafórico que é capaz de trazer a experiência de uma nova referência reveladora do mundo do texto.

A tarefa da crítica, para Nunes, tem como objetivo ressaltar os momentos de repetição, os paradoxos, as inovações sintáticas e sonoras, o ritmo, as inúmeras figuras de linguagem que povoam as obras analisadas para investigá-las em face dos questionamentos históricofilosóficos e abordá-las de forma a deixar vir à tona reflexões que são confrontações do e para o pensamento.

Há, portanto, um modo de pensar, uma forma de ler que privilegia o instrumental da criação para colocá-lo em relevo. Se há indagações filosóficas nesse processo, é porque sabemos, como já o disse Paul de Man (1992, p.34), que “toda literatura é, até certo ponto, filosófica (...) por uma ausência recíproca de identidade ou especificidade”. Ou antes, que toda filosofia está “condenada, na medida em que é dependente da figuração, a ser literária”.

Para Benedito Nunes, não importa discutir o porquê do recurso metafórico; importa mostrá-lo como marca da escritura, de um fazer textual que é característico do discurso. Por isso, há metáforas espelhadas, reescritas como traços dominantes de uma investigação que se meneia entre o conceitual e a criação de imagens. Conceito e metáfora não "implicam uma hierarquia, nem muito menos se identificam, respectivamente, com uma visão direta e oblíqua do 'referente'. Conceito e metáfora são possibilidades igualmente proposicionais”. (COSTA LIMA, 1989, p.182)

A espécie de simbiose que Nunes pratica ao incorporar, às vezes, as metáforas da obra analisada desencadeiam questões quanto à natureza dessa atitude. Em outras palavras: como se caracterizam essas metáforas? Qual a sua função, visto serem empregadas em campos discursivos diferentes? Qual a concepção de metafórico que se sobressai do seu projeto crítico?

Há de se ter claro que ele não tem a intenção de parafrasear a metáfora ${ }^{4}$ literária como a tentar elucidar as imagens poéticas para algum leitor ávido de respostas prontas. Tão

\footnotetext{
${ }^{4}$ A respeito dessa questão Cf. ECO, Umberto. Metáfora e Paráfrase. In: Os limites da interpretação. Trad. Pérola de Carvalho. São Paulo: Perspectiva, 2000, p.129-0.
} 
pouco pretende explicá-la a fim de traduzir a possível "intenção"5 do autor ou o suposto sentimento originado de tal expressão. Antes, ele "tenta reproduzir nos outros alguns dos efeitos que o original produziu sobre ele. Ao fazê-lo, o crítico também (...) chama a atenção para a beleza ou adequação, para o poder oculto da própria metáfora”. (DAVIDSON In: SACKS, 1992, p.51)

A crítica de Nunes, ao compartilhar da criação verbal do poeta/prosador, alia a sensibilidade teórica e a analítica como a de quem concorda, como Ricoeur (1990, p.104), de que o mais importante é desvelar a referência do texto, o mundo o qual ela descortina e redescreve. Compreender um texto, portanto, é postar-se perante o mundo da obra, para entendê-lo e, por extensão, entender a si mesmo, já que “toda interpretação envolve (...) uma preliminar e antecipada autocompreensão do intérprete”. (NUNES, 1999, p.57)

A referência própria do texto, ou de segundo grau, conforme o filósofo francês, é onde repousa o campo da metáfora, a estratégia de discurso responsável por permitir à interpretação uma dinâmica de leitura que não procura algo que está por detrás do texto, mas apropria-se das questões abertas pela potência criadora da linguagem poética.

Ao proceder a uma leitura hermenêutica, é o conceito de metáfora, discutido por Ricoeur, que Nunes corrobora nas suas abordagens. Vale lembrar que os estudos de Ricoeur a respeito desse assunto não se separam do arcabouço teórico desenvolvido no restante da sua obra. São temas ${ }^{6}$ que, articulados, formam uma correlação necessária para a compreensão da metáfora - da metáfora viva, a bem dizer: a relação entre Fenomenologia e Hermenêutica; a amplitude da noção de experiência; o problema da dimensão temporal da experiência humana; a revisão da idéia de imaginação; a referência, como ponto fundamental na sua concepção; e o texto, como modelo interpretativo ${ }^{7}$.

O caráter interdisciplinar que Ricoeur promoveu, ao estreitar o diálogo entre lingüística, crítica literária e filosofia da linguagem, e com as diversas teorias semânticas vigentes na sua época, desencadeou uma reflexão acerca da metáfora, principalmente àquela

\footnotetext{
${ }^{5}$ Novamente, aqui, pode-se lembrar Eco. Para ele, mais importante que especular acerca da intenção do autor é ser capaz de indagar as intenções do texto. Cf. ECO, Umberto. Entre autor e texto. In: Interpretação e superinterpretação. Trad. MF. São Paulo: Martins Fontes, 1993, p. 79-104. Paul Ricoeur (2000, p.87) também concorda que "temos de conjecturar o sentido do texto porque a intenção do autor fica para além do nosso alcance".

${ }^{6}$ Cf. PEREIRA, Miguel Baptista. A tradução portuguesa de Metáfora Viva de Paul Ricoeur. In: RICOEUR, Paul. A metáfora viva. Trad. Joaquim Torres Costa e António M. Magalhães. Portugal: Rés Editora Ltda., 1983, p.I- XLV.

${ }^{7}$ Esses tópicos foram, ao menos em substância, discutidos nos capítulos precedentes. Cf. itens I.4.1 (Breves interfaces do pensamento hermenêutico), p.88-91; I.4.2. (Hermenêutica e crítica literária: o intérprete Benedito Nunes), p.95-9; e II.4.1.(Contrapontos), p.169-172.
} 
presente em La Métaphore Vive (1975) ${ }^{8}$, explorada nos seguintes planos de investigação: do retórico ao semiótico; do semântico ao hermenêutico. Por fim, analisa a referência metafórica e a filosofia aí implícita.

Afirmar que no discurso crítico de Nunes a metáfora se apresenta como constitutiva de uma leitura, cuja principal qualidade é dizer algo de novo acerca da realidade, significa reiterar a não-ornamentalidade do metafórico e mostrar que, seja em qual campo discursivo for, a metáfora não apresenta a mesma função.

Nesse sentido, o horizonte crítico, em que se inscreve o traço metafórico de Nunes, autoriza discutir os limites específicos entre o poético e o não-poético; entre a ficcionalização da crítica e uma exposição que se quer nem científica nem ficcional. Para isto, cumpre ressituar as várias posturas analíticas em cujo centro de estudo a metáfora teve papel determinante.

Embora o interesse não seja descrever a história da metáfora, as diferentes acepções assumidas por esta no espaço da poética, da retórica, da lingüística, da psicanálise, da filosofia, por exemplo, contribuem para se aventar questões quanto à natureza da interpretação e à da atividade crítica. Essas acepções, aliás, resumem, como pontuou David Wellber (1990), a história da Teoria da Literatura.

Em conseqüência, ao se debater a respeito de tais posturas, tentar-se-á criar um alicerce para melhor fundamentar como e de que modo a leitura do metafórico empreendida por Nunes repousa, como já apontado, no conceito ricoeuriano. É preciso esclarecer, no entanto, que não se trata de uma escolha aleatória nem se tem a pretensão de defender um teórico em detrimento de outro. Trata-se, antes, de tensionar as variáveis da interpretação da metáfora para fazer emergir uma posição que defenda o caráter expressivo e cognoscitivo dessa figura.

Com esse fim, intenta-se dividir o capítulo em dois momentos: no primeiro, as principais epistemologias da metáfora serão revisitadas e refletidas para, em um segundo, servirem de ponte para a abordagem da crítica nuneana.

Neste item, para melhor ilustração, trabalhar-se-á somente com suas críticas literárias, quer de prosadores, quer de poetas. Os exemplos serão escolhidos dentro de um recorte que acentuará os aspectos semânticos, sintático-morfológicos, fônicos etc. Dessa

\footnotetext{
${ }^{8}$ Ricoeur dedica ao tema da metáfora outros artigos; entre eles, destacam-se "O processo metafórico como cognição, imaginação e sentimento" (in: SACKS, 1992) e “Metáfora e símbolo” (In: Teoria da Interpretação, 2000).
} 
forma, privilegiará como e de que maneira Nunes seleciona e constrói sua linguagem crítica ao ler a obra literária. O objetivo de tal empenho, portanto, é o de acompanhar e pôr em relevo a sua prática de leitura hermenêutica, em que se sobressai inscrito, por vezes, o metafórico.

\section{III.1. Metáfora: principais linhas de reflexão}

Ainda que a intenção não seja recontar a história da metáfora stricto sensu, como já anunciado, é preciso salientar, no entanto, alguns traços essenciais dos variados estudos que a têm como cerne, a fim de rastrear e enfatizar a sua natureza multidisciplinar e epistemológica.

Neste contexto, a metáfora é considerada não só como fenômeno lingüístico, mas também filosófico ${ }^{9}$, posto que, como linguagem, propõe um problema para o pensamento, qual seja, diferenciar entre o que é e o que não é metafórico.

Oliveira (1999, p.119) destaca duas linhas possíveis quando se considera a evolução do conceito de metáfora: a) como processo de denominação, vinculada à palavra e pertencente ao campo paradigmático: Aristóteles, Pierre Fontanier, K. Buhler, H. Konrad, Pierre Guirraud, Umberto Eco; b) entendida como metáfora-enunciado, de predicação, relativo ao campo sintagmático: Escola Anglo-Saxônica - I. A. Richards, Max Black e Beardsley.

Entretanto, diante desses eixos, muitas outras trilhas se abrem - por exemplo, a análise ontológica da metáfora -, conquanto Eco (1991, p.142) afirma que das "milhares de páginas escritas sobre a metáfora, poucas acrescentaram algo àqueles primeiros dois ou três conceitos fundamentais enunciados por Aristóteles”10.

De fato, as reflexões contemporâneas ainda têm como fonte a noção de metáfora de Aristóteles, que garantia a esta uma caracterização não só expressiva, mas também cognoscitiva $^{11}$, assunto do qual se falará mais adiante.

Por ora, basta assinalar que, se as formulações feitas pelo Estagirita apresentam essa tensidade, isto é, não possuem uma qualidade uniforme, em Quintiliano, ao contrário, a metáfora é considerada um ornamento, uma questão de estilo ${ }^{12}$.

\footnotetext{
${ }^{9}$ Para Derrida (1972, p.261), a metáfora é uma invenção da filosofia, "un philosophème classique, un concept métaphysique”.

${ }^{10}$ Francisco Filipak (1983, p.14) corrobora essa idéia: “as grandes linhas mestras da metáfora foram traçadas pelo Estagirita e as demais teorias supervenientes vêm apenas clarificar, explicitar, reanimar e complementar a visão da metáfora de Aristóteles".

${ }^{11}$ Costa Lima trabalhou com este tema de maneira mais incisiva em "Metáfora: do ornato ao transtorno". In: Aguarrás do tempo - estudos sobre a narrativa. Rio de Janeiro: Rocco, 1989, p.123-186. Eco vai se referir à mesma questão em "Metáfora e semiose”. In: Semiótica e filosofia da linguagem. Trad. M. Fabris e José Luiz Fiorin. São Paulo: Ática, 1991, p.141-194.
} 
O interesse em se discutir a metáfora, portanto, incide no horizonte dos planos da expressão e do conhecimento, na medida em que estes permitem um maior questionamento quanto à problemática da interpretação da atividade crítica. A metáfora-ornato, por outro lado, será responsável, segundo Costa Lima (1989, p.125), pelas “dificuldades que cercam a melhor compreensão do estatuto do ficcional (...). Igual desserviço só será prestado pela concepção substancialista da verdade, como adequação entre o que se diz e a natureza daquilo sobre o que se fala”.

A metáfora em Aristóteles aparece como objeto de questão na Poética (1991a) e na Retórica (2005) ligada, respectivamente, à mímesis das ações humanas na tragédia e à persuasão, característica exigida pela eloqüência. A esta última obra, pode-se aproximar o tratado dos Tópicos $(1991)^{13}$, em cuja linha argumentativa sobressai-se o caráter dialético.

Ricoeur (1975, p.19) sublinha que quer a Retórica tenha sido redigida quer somente modificada após a Poética, a definição adotada foi a da composição da arte mimética e se limitou à analítica da lexis (expressão): “a metáfora consiste no transportar para uma coisa o nome de outra, ou do gênero para a espécie, ou da espécie para o gênero, ou da espécie de uma para a espécie de outra, ou por analogia ${ }^{14 » . ~(A R I S T O ́ T E L E S, ~ 1991 a, ~ p .220) ~}$

Esse transporte - epífora - se efetua entre dois termos e constitui uma posição de desvio, pois há um deslocamento do sentido das palavras, embora o vocábulo “desvio” não pareça ser, necessariamente, antônimo de normal. Tal deslocamento atinge o nome, isto é, a parte da lexis envolta de carga semântica (o substantivo e o verbo) e também “toutes les entités du langage qui portent le sens et que ce procès désigne le changement de signification comme tel”. (RICOEUR, 1975, 24)

Assim, a dinâmica da metáfora (Cf. Ricoeur, 1975, p.24) está circunscrita a aproximar elementos que, mesmo sendo diferentes, são, contudo, passíveis de serem identificados por meio de algum traço de qualidade que permita a transferência da denominação. Diferente da comparação, em que essa semelhança é explicitada por

\footnotetext{
${ }^{12}$ Cf. QUINTILIANO, M. F. Institution oratoire. 4 vols. Trad. Henri Bornecque. Paris: Garnier, 1954. A respeito do autor romano Cf. HANSEN, João Adolfo. A alegoria como expressão ou alegoria retórica ou alegoria dos poetas. In: Alegoria - construção e interpretação da metáfora. São Paulo: Atual, 1996, p.12-42.

${ }^{13}$ Cf. PERELMAN, Chaïm. Rhétoriques. Bruxelles: Éditions de l’Université de Bruxelles, 1989.

${ }^{14}$ Na Retórica (2005, p.266), Aristóteles concebe maior importância a este quarto tipo. Entretanto, como assinala Costa Lima (1989, p.170), "um traço majoritário na discussão contemporânea é a negação" da analogia, contestada por, entre outros, Eco (1991, p.176): “A metáfora, porém, põe em jogo não só a semelhança, mas também as oposições. A taça e o escudo são semelhantes no que diz respeito à forma (redonda e côncava), mas opostos no que diz respeito à função (paz X guerra), assim como Ares e Dioniso são semelhantes enquanto deuses, mas opostos quanto aos objetivos que perseguem e aos instrumentos que utilizam”. (grifo do autor)
} 
componentes de ligação (como, já que etc.), na metáfora, é a ausência de qualquer processo de identificação entre os termos que garante uma enunciação inusitada e até, segundo disse Nietzsche no Livro do Filósofo (1984), ilusória.

A definição aristotélica, contudo, é contestada hodiernamente por, entre outros, Eco (1991, p.147-157). Para o pensador italiano, os três primeiros exemplos ${ }^{15}$ são sinédoques e aludem a "como" a metáfora é compreendida. O quarto tipo, a “o que” a metáfora faz conhecer. Seria aqui, no entanto, excessivo rediscutir essa questão apontada por Eco, até porque a proposta é dirimir dúvidas quanto à concepção da metáfora apenas como fenômeno decorativo. Neste sentido, faz-se necessário comentar sucintamente a sua inserção tanto na Poética quanto na Retórica.

Como é de conhecimento geral, Aristóteles concedeu à arte retórica uma nova perspectiva, diferente dos sofistas, como Górgias, e desenvolvida com base naquela defendida por Platão em Fedro.

A função da retórica aristotélica era preocupar-se em revelar meios de persuasão e não simplesmente persuadir. Era esse, aliás, o ponto que a diferenciava dos seus precedentes. Em Górgias, a retórica sofística valorizava a força persuasiva da emoção e o orador era visto como um psicagogo, “um guia de almas mediante uma espécie de encantamento”. (ALEXANDRE JR. In: ARISTÓTELES, 2005, p.20) Havia na arte de persuadir, dessa forma, uma habilidade técnica em adaptar o discurso conforme o público; por isso o cuidado com o estilo, com a linguagem.

Já em Platão, a verdadeira retórica é a dialética. Seu ataque à retórica sofística é porque esta era a arte do engano, da ilusão, já que não havia um compromisso com a verdade, ou o bem-estar da comunidade, mas somente o de convencer o auditório. Para ele, havia esta falsa retórica que dava mostra de saber o que na verdade não sabia e havia uma retórica autêntica que sabia efetivamente o que mostrava saber. (Cf. Plebe, 1978, p.28)

Platão, assim, reprovava somente a retórica atenta à aparência e não à substância pelo menos em Fedro - e que se afastava da fundamentação na dialética: “(...) Acho muito

\footnotetext{
${ }^{15}$ Os exempos são: do gênero para a espécie: “'Aqui minha nave se deteve', pois o 'estar ancorado' é uma espécie do gênero deter-se”; da espécie para o gênero: “"Na verdade, milhares e milhares de gloriosos feitos Ulisses levou a cabo', porque "milhares e milhares está por 'muitos', e o poeta se serve destes termos específicos, em lugar do genérico 'muitos'”; da espécie para espécie: “"Tendo-lhe esgotado a vida com seu bronze' e 'cortado com o duro bronze' (...), no primeiro, o poeta usou, em lugar de 'cortar', 'esgotar', e no segundo, em lugar de 'esgotar', 'cortar'; mas ambas as palavras especificam o 'tirar a vida'”; por analogia: "a 'urna' está para 'Dionísio’, como o ‘escudo’ para ‘Ares', e assim se dirá a urna 'escudo de Dioníso', e o escudo, ‘urna de Ares’”. (Cf. ARISTÓTELES, 1991a, p.220-1)
} 
mais bela a discussão destas coisas quando se semeiam palavras de acordo com a arte dialética, uma vez encontrada uma alma digna para receber as sementes!” (PLATÃO, 1989, p.125)

Aristóteles não se “distancia da visão retórica do Fedro", mas concebe a retórica dotada de uma argumentação lógica, preocupado em defender sua neutralidade, a fim de mostrar que depende do orador, "não do sistema retórico, o uso responsável ou não das técnicas de persuasão”. (ALEXANDRE JR. In: ARISTÓTELES, 2005, p.24; 28)

Como lembra Ricoeur (1975, p.16), o Estagirita é o responsável por integrá-la à filosofia. Constituída por três partes - a argumentação, a elocução e a composição -, o que "les derniers traités de rhétorique nous offrent, c’est, selon l’heureuse expression de G. Genette, une 'rhétorique restreinte ${ }^{, 16}$, restreinte d'abord à la théorie de l'élocution, puis à la théorie des tropes”. (p.13) Ao limitá-la a apenas uma parte, a retórica perdeu o vínculo com a filosofia por meio da dialética, o que a tornou uma disciplina “erratique et futile”17.

Para Aristóteles (Cf. 2005, p.89), a retórica e a dialética se identificam pelo fato de que o assunto de ambas pode pertencer a qualquer gênero. Com efeito, os dois discursos se utilizam da argumentação, embora a retórica vise a "discernir os meios de persuasão a cada caso, tal como acontece em todas as outras artes”. (ARISTÓTELES, 2005, p.94)

Pode-se perceber que, desde Tópicos (1991, p.5), a argumentação é discutida com o intuito de oferecer aos discursadores um “método de investigação graças ao qual possamos raciocinar, partindo de opiniões geralmente aceitas, sobre qualquer problema que nos seja proposto”. Tal raciocínio é a dialética, definida como um processo crítico adequado a uma argumentação geral, na ordem do verossímil ${ }^{18}$, cuja característica é atuar com base no provável e ser admitida por um número estimável de pessoas e sábios.

Já na Retórica, a argumentação tem caráter persuasivo, formalizada por meio de duas categorias de provas: o entimema, de natureza dedutiva, e o exemplo, de cunho indutivo.

O entimema é uma espécie de silogismo, e que é do silogismo em todas as suas variantes que se ocupa a dialética, no seu todo ou nalguma das suas partes, e é igualmente evidente que quem melhor puder teorizar sobre premissas - do que e como se produz um silogismo - também será o mais hábil em entimemas, porque sabe a que matérias se aplica o entimema e que diferenças este tem dos silogismos lógicos. (ARISTÓTELES, 2005, 93)

\footnotetext{
${ }^{16}$ GENETTE, Gerard. Rhétorique restreinte. In: Communications, 16, Paris, Ed. du Seuil, 1970.

${ }^{17}$ Acerca do resgate da retórica em uma concepção moderna Cf. WELLBERY, Davi E. Retoricidade: sobre o retorno modernista da retórica. In: Neo-retórica e desconstrução. Organização de Luiz Costa Lima e Johannes Kretschmer. Rio de Janeiro: Ed. UFRJ, 1998, p.11-47.

${ }^{18}$ Cf. Ricoeur (1975, p.42).
} 
Ambas, a dialética e a retórica, dessa maneira, assemelham-se, porque "nenhuma das duas é ciência de definição de um assunto específico, mas mera faculdade de proporcionar razões para os argumentos”. (ARISTÓTELES, 2005, p.97)

Contudo, pode-se ressaltar uma linha diferencial entre elas: embora não seja uma teoria, a dialética dela se aproxima, ao contrário da retórica, que é mais uma prática argumentativa. De fato, se o propósito da dialética é instruir para uma argumentação mais geral, como apontado anteriormente; o da retórica é específico à persuasão, o que a distingue em três espécies: judicial, deliberativa e epidíctica. (Cf. ARISTÓTELES, 2005, p.104)

Por outro lado, os dois discursos têm pontos em comum com a poética. Claro está que esta não tem como objetivo nem a argumentação dialética, nem a retórica persuasiva. Todavia, também se constitui uma preleção pública: com a dialética, a poética "guarda certa proximidade pelo caráter reflexivo, que indiretamente, também a acerca da filosofia”19; com a retórica se “aproxima porque ambas fazem uso das emoções do público”. (COSTA LIMA, 1989, p.136-7)

Tanto na Retórica quanto na Poética, Aristóteles comenta os efeitos produzidos na assembléia. Nesta, ocorre o terror e a piedade, que são efeitos da ação dramática, pelos quais acontece a catarse de tais emoções. Naquela,

\begin{abstract}
compadecemo-nos também das pessoas conhecidas, desde que a nossa relação com elas não seja demasiado íntima (pois, neste último caso, partilhamos com elas os mesmos sentimentos que sentimos conosco, razão pela qual Amasis, segundo dizem, não chorou pelo filho que conduziam à morte, mas por um amigo seu que pedia esmola: o caso do amigo é digno de piedade, o do filho é horrível, e o horrível é diferente do que é digno de compaixão, exclui mesmo a piedade e, muitas vezes, até é útil para provocar emoções contrárias, uma vez que ainda não sentimos compaixão quando o que é terrível está perto de nós). (ARISTÓTELES, 2005, p.186)
\end{abstract}

Outro traço que une a poética e a retórica é o uso de metáforas, pois este "elemento possui a maior eficácia tanto na poesia como no discurso oratório”. (ARISTÓTELES, 2005, p.246)

Tal eficácia ocorre, porque a metáfora contribui para a clareza de estilo, principalmente por força da característica da semelhança ${ }^{20}$. Para Aristóteles, “o movimento metafórico do conhecido para o desconhecido por meio de uma semelhança entre os dois é a

\footnotetext{
${ }^{19}$ É sob este aspecto que Aristóteles (1991a, p.209) defende que a poesia "é algo de mais filosófico e mais sério do que a história, pois refere aquela principalmente o universal, e esta o particular".

${ }^{20}$ Ricoeur (1975, p. 221-272) retoma e interpreta a teoria aristotélica a respeito da semelhança baseado em um ângulo de estudo menos histórico e mais sistemático.
} 
estrutura que subjaz a todo raciocínio humano”. (ALEXANDRE JR. In: ARISTÓTELES, 2005, p.48) Por isso, o uso retórico para as metáforas é correlato ao dos silogismos do tipo entimema: parte-se do familiar para o menos familiar, do que se sabe para o que não se sabe.

No entanto, nem sempre há clareza na analogia; portanto, a escolha das metáforas interfere diretamente na arte retórica: “é forçoso que as metáforas provenham de coisas apropriadas ao objeto em causa, mas não óbvias, tal como na filosofia é próprio do espírito sagaz estabelecer semelhança mesmo com entidades muito diferentes”. (ARISTÓTELES, 2005, p.270)

Do mesmo modo, na Poética (1991a, p.223), o emprego das metáforas é de “grande importância (...) e revela portanto o engenho natural do poeta; com efeito, bem saber descobrir as metáforas significa bem se aperceber das semelhanças”.

Em ambas, assim, é imprescindível o cuidado com a linguagem, posto que, selecionar a metáfora adequada está "entre as habilidades mais difíceis e é habilidade comum ao poeta e ao retor”. (PLEBE, 1978, p.50)

Essa questão, por certo, já aponta que, ao lado do aspecto expressivo, a metáfora também tem um valor cognoscitivo, porquanto ela não é apenas um ornamento ${ }^{21}$, mas implica funcionar ora como ação retórica, ora como efeito constitutivo da criação poética.

Com base em uma passagem da Poética (1991a, p.221), percebe-se que a metáfora aristotélica assume um papel importante, além do ornato, principalmente quando preenche um possível vazio do léxico:

Por vezes falta algum dos quatro nomes na relação analógica, mas ainda assim se fará a metáfora. Por exemplo, "lançar a semente” diz-se "semear”; mas não há palavra que designe "lançar a luz do sol”, todavia esta ação tem a mesma relação com o sol que o semear com a semente; por isso se dirá "semeando uma chama criada pelo deus”.

Ainda sob este aspecto, Aristóteles (1991a, p.222) acentua que não saber usá-la pode incorrer no enigma ou no ridículo:

(...) é elevada a poesia que usa de vocábulos peregrinos e se afasta da linguagem vulgar. Por vocábulos 'peregrinos' entendo as palavras estrangeiras, metafóricas, alongadas e, em geral, todas as que não sejam de uso corrente. Mas a linguagem composta apenas de palavras deste gênero será enigma ou barbarismo; enigmático se o for só de metáforas, bárbara, se exclusivamente de vocábulos estrangeiros. (...) É certo que, pelo demasiado evidente destes modos, se incorre no ridículo e, por outro lado, a moderação também é necessária nas outras partes do discurso; pois

\footnotetext{
${ }^{21}$ Como legitima Eco (1991, p.161), “a metáfora não é só instrumento de deleite, mas também e sobretudo instrumento de conhecimento".
} 
metáforas, estrangeirismos (...) impropriamente usados, produziriam o mesmo resultado, se de propósito nos servíssemos deles para provocar o riso.

Na Retórica (2005, p.248), ao contrário, o enigma é responsável pela ocorrência da metáfora: “é, com efeito, a partir de bons enigmas que se constituem geralmente metáforas apropriadas. Ora, metáforas implicam enigmas e, por conseguinte, é evidente que são bons métodos de transposição".

De acordo com Costa Lima (1989, p.151), “se a transferência metafórica é exitosa quando se deixa reconhecer como um enigma velado, que isso pode significar senão que nela se identifica... um efeito de conhecimento?”.

Do exposto até aqui, ainda que de forma sumária, apreende-se o duplo enfoque que Aristóteles concedeu à metáfora: ora ela, como um enigma, pode levar ao riso, ao ridículo, por isso deve ser evitada; ora ela é parte essencial na construção do discurso. Em outras palavras: ora ela se inscreve como ornamento, ora como produtora de conhecimento.

Embora o Estagirita designasse um enfoque secundário ${ }^{22}$ ao metafórico na sua teoria, verifica-se que o ornamento não é sinônimo de supérfluo, pois a metáfora pode servir plasticamente ao discurso como reforço de uma expressão em uma circunstância textual que assim a exigir. Por outro lado, em outros contextos expositivos, sua presença é necessária como portadora de uma função cognoscitiva.

Dessa concepção tensa deriva-se que a metáfora "se ajusta a uma gama variada de discursos, historicamente configurados e portadores de demandas diversificadas” (COSTA LIMA, 1989, p.154), como o discurso crítico. Tal discurso, é bom lembrar, será objeto, posteriormente, de uma investigação mais pormenorizada.

De maneira lúcida, Eco (1991, p.163-4) assim resume a importância de Aristóteles para o estudo da metáfora:

Aristóteles derrotou, desde o início, tanto os teóricos da metáfora fácil quanto os
moralistas clássicos, que temiam sua natureza cosmética e mentirosa, tanto os
imoralistas barrocos, que a queriam apenas e apimentadamente agradável, quanto,
enfim, os semanticistas hodiernos, que vêem o ornato retórico, no máximo, como
uma estrutura ainda mais superficial do que a estrutura de superfície, incapaz de
arranhar as estruturas profundas, sejam elas sintáticas, semânticas ou lógicas.

${ }^{22}$ Enfoque este apontado por, entre outros comentadores, Derrida (1972, p.283-4): “La métaphore, effet de mimesis et d'homoiosis, manifestation de l'analogie, sera donc um moyen de connaissance. Subordonné mais certain”. 
Estabelecidas, pois, as bases aristotélicas da metáfora ${ }^{23}$, duas questões, pelo menos, merecem ser sublinhadas: 1) a questão da mímesis que, como recorda Eco (1991, p.163), é associada ao cognoscitivo; e 2) a metáfora como resultante de um processo interpretativo. Neste momento, examinar-se-á, em especial, a contribuição de Paul Ricoeur e o diálogo que ele constrói com outros pensadores.

\section{III.1.1. A metáfora como mímesis}

É conveniente relembrar que, neste espaço e no anterior, a reflexão acerca da metáfora tem um caráter de fundamento, de suporte, para que, ulteriormente, possa se discutir o metafórico inscrito na atividade crítica de Benedito Nunes.

Dessa forma, o recorte e a seleção de conceitos e de autores obedecem ao critério da relevância que certos aspectos e pensamentos teóricos acrescentarão ao tema.

Sabe-se que a concepção de mímesis abarca dimensões profundas que envolvem não só um indagar a respeito da metáfora, mas também a propósito da linguagem, da representação, da arte, da literatura etc. Em outros termos: tal assunto é demasiado complexo e, por isso, exige uma demarcação mais nítida quanto ao traço que se deseja ressaltar, a fim de que esta reflexão não se perca no emaranhado de noções e posições excessivas à sua problemática de estudo.

Em face disto, pretende-se apresentar sucintamente a idéia de metáfora como mímesis na proposta de Ricoeur ${ }^{24}$, que fomenta indagações essenciais para o debate da ensaística nuneana.

Embora indispensáveis quando se trata de uma compreensão mais atual de mímesis, passar-se-á ao largo das considerações, por exemplo, de Adorno $^{25}$, de Benjamim ${ }^{26}$ e, entre

\footnotetext{
${ }^{23}$ Isto porque, como disse Derrida (1972, p.275): “Il y a un code ou un programme - une rhétorique, si l'on veut - pour tout discours sur la métaphore: suivant l'usage, il faut en premier lieu rappeler la définition aristotélicienne, du moins celle de la Poétique (1457b). Nous n’y manquerons pas. Aristote, certes, n’a inventé ni le mot ni le concept de métaphore. Il semble pourtant en avoir proposé la première mise en place systématique, celle qui en tout cas fut retenue comme telle avec les effets historiques les plus puissants".

${ }^{24}$ No item II.4.1. (Contrapontos), o estudo da mímesis, por Ricoeur, já foi abordado brevemente. Cf. p.169-172.

${ }^{25}$ Cf. ADORNO, T. W. Teoria estética. Trad. Artur Mourão. São Paulo: Martins Fontes, 1982 e ADORNO T. W. e HORKHEIMER, M. Dialética do esclarecimento. Trad. Guido de Almeida. Rio de Janeiro: Zahar, 1985.

${ }^{26}$ Cf. Obras escolhidas. Vol. I. $3^{\mathrm{a}}$ ed. Trad. S. P. Rouanet. São Paulo: Brasiliense, 1987 e Obras escolhidas. Vol. II. Trad. R. R. Torres Filho e J. C. M. Barbosa. São Paulo: Brasiliense, 1987. A respeito dos dois autores Cf. GAGNEBIN, Jeanne Marie. Do conceito de mímesis no pensamento de Adorno e Benjamin. In: Sete aulas sobre linguagem, memória e história. Rio de Janeiro: Imago, 1997, p.81-106.
} 
nós, de Costa Lima ${ }^{27}$, pois estes estão preocupados em repensar tal fenômeno mais em um sentido amplo do que restrito à relação metafórica.

De qualquer modo, para melhor entendimento da questão, faz-se necessário revisitar, ainda que de maneira sintética, as ponderações de Aristóteles.

Na obra do Estagirita, a mímesis ganhava contornos mais definidos, isto é, era sistematizada e valorizada, ao passo que, na de Platão, ela era recusada com base em duas justificativas: uma, de natureza pedagógica; outra, de cunho ético-epistemológico. Para o autor de Diálogos, “como textos poéticos, a exemplo dos homéricos, constituíam a base da educação grega, ao filósofo repugnava pensar que os estudantes se 'tornassem trapaceadores' (deceivers)” (COSTA LIMA, 2000, p.31) e que alguns deles fossem iludidos pela pretensão de conhecimento.

Percebe-se, assim, que traduzir mímesis por “imitação” restringe seu sentido e alcance. Para os gregos clássicos, a palavra arte (tekhne) tinha um âmbito significativo maior, pois compreendia tanto a produção manual e industrial, quanto a habilidade de se criar algo. A música, a literatura, a dança eram designadas como artes miméticas. Dito de outra maneira: a arte era pensada como uma "figuração enraizada na mímesis, na representação, ou melhor, na ‘apresentação’ da beleza do mundo’ (mais Darstellung que Vorstellung)”²8; por isso, insistiase na "fidelidade da representação ao objeto representado: é ele, o objeto, que desencadeia, por sua beleza, o impulso mimético”. (GAGNEBIN, 1997, p.82)

Ricoeur (1975, p.54) acentua que a mímesis, em Platão, tinha um alcance amplo, pois era extensiva a todas as artes, aos discursos, às instituições, às coisas naturais que eram reproduções dos modelos ideais. Havia uma relação muito geral entre uma coisa que é e outra que parece e esta semelhança podia ser boa ou não: "La référence à des modèles idéaux permet seulement de constituer une échelle de ressemblance selon que varie l'approximation de l’être par l'apparence”.

Neste sentido, a concepção platônica criticava a imagem mimética, pois ela, a imagem - quer seja plástica, quer seja poética -, era uma cópia, afastada por três degraus da essência (idéia) das coisas. Esta levava ao engano, à ilusão; deveria ser, pois, controlada por

\footnotetext{
${ }^{27} \mathrm{O}$ conceito de mímesis é o principal tema de estudo do autor em obras como Mímesis e modernidade - formas das sombras ( $2^{\mathrm{a}}$ ed. São Paulo: Paz e Terra, 2003 - com prefácio de Benedito Nunes); Mímesis: desafio ao pensamento (Rio de Janeiro: Civilização Brasileira, 2000); e Vida e mímesis (São Paulo: Ed. 34, 1995). Nestes livros, a mímesis é discutida de forma metódica em pensadores como Hegel, Freud, Nietzsche, Auerbach, entre outros.

${ }^{28}$ Igual definição é encontrada em Costa Lima (1995, p.65): “(...) fenômeno básico de expressão, ela [a mimesis] antes põe do que expõe; é apresentação e não, basicamente, representação”. (grifo do autor)
} 
normas éticas e políticas para que as pessoas não se deixassem lograr pelos enlevos da arte. O poeta, dessa forma, era considerado um homem de terceira categoria, passional e nocivo à sociedade, porquanto estava afastado da verdade.

Ainda que, por força das fronteiras exigidas para esta reflexão, seja demasiado aprofundar o conceito platônico, não é desnecessário lembrar que Platão condenava apenas o poeta que não se deixava inspirar pelas musas, como se verifica nesta passagem de Fedro (1989, p.52):

Há ainda uma terceira espécie de loucura, aquela que é inspirada pelas Musas: quando ela fecunda uma alma delicada e imaculada, esta recebe a inspiração e é lançada em transportes, que se exprimem em odes e em outras formas de poesia, celebrando as dos Antigos, e assim contribuindo para a educação da prosperidade. Seja quem for que, sem a loucura das Musas, se apresente nos umbrais da Poesia, na convicção de que basta a habilidade para fazer o poeta, esse não passará de um poeta frustrado, e será ofuscado pela arte poética que jorra daquele a quem a loucura possui.

Em síntese, para o encaminhamento que busco, o comentário de Benedito Nunes (1999, p.24-5) a respeito da mímesis platônica encerra o assunto:

Considerando-se os aspectos éticos da condenação do poeta em A República, que recai sobre o mimethes (...), o que prevalece (...) é a elevação do poeta inspirado e o rebaixamento do imitador. Diante da verdade contemplada, por aquele, que não é senão a noèsis do ser eternamente imutável (o onthos ón), o mito e a poesia não são ilusórios como doxa, e sim “mentirosos”, porque têm a aparência da verdade. Dizia Platão, no Crátilo (408 c), que o lógos é diplous - alethés e pseudós. Ele nos traz palavras de engano, como a dos sofistas, coisas enganadoras (pseudós), simulacros da realidade, formando, então, aquele "terceiro domínio" que, modernamente, conceberíamos como o âmbito da imaginação.

Já em Aristóteles, a atividade mimética ${ }^{29}$ era concebida como natural ao ser humano (Cf. 1991a, p.203). Seu interesse era saber como e não o quê deveria ser representado; por isso, indagava pela habilidade mimética do homem, pelo mimeisthai ${ }^{30}$ no qual se encontrava a poietiké, a criação de uma obra artística.

\footnotetext{
${ }^{29}$ É importante lembrar que o conceito de mímesis aristotélica se completa e se define com o auxílio das noções de verossimilhança e de necessidade, como componentes indispensáveis para a organização da lógica interna da obra. Cf. BRANDÃO, Roberto de Oliveira. A tradição sempre nova. São Paulo: Ática, 1976, p.44-5. Costa Lima (1989, p.133) lembra que uma das "razões por que a mímesis não se confunde com a imitação está em que esta não seria aceitável enquanto postuladora de inverossimilhanças”.

${ }^{30}$ Costa Lima (2000, p.34), com base nos comentários filológicos de Dupont-Roc e Lallot, afirma que “mimeisthai tem o sentido de 'formar uma imagem' (...)”. Em Platão e Aristóteles, “a mímesis supõe um ato de adequação ou correspondência entre a imagem produzida e algo anterior - em Platão, anterior e superior - que a guia. Ao lado deste lastro comum, é certo entender-se que a mímesis aristotélica adquire um acentuado grau de liberdade quanto a este algo anterior, seja por seu próprio ato de feitura, seja pelo efeito que causa”.
} 
Para Ricoeur (1996, p.330), a mímesis é o conceito norteador da Poética, ligada à práxis humana, o que a aproxima da ética. Mímesis, mythos e katharsis formam os termos marcantes desse texto aristotélico e o mythos, em especial, terá papel relevante na discussão a respeito da metáfora; questão esta que será salientada mais adiante.

O Estagirita realçava, ao contrário de Platão, que a mímesis levava ao conhecimento, pois o que era conhecido não era o objeto reproduzido, mas a relação entre a imagem e o objeto. Ao reconhecer essa relação, o homem sentia prazer; prazer este que podia acontecer até da contemplação de imagens execráveis à vista: Ao que parece, duas causas, e ambas naturais, geraram a poesia. O imitar ${ }^{31}$ é
congênito no homem (e nisso difere dos outros viventes, pois, de todos, é ele o mais
imitador, e, por imitação, aprende as primeiras noções), e os homens se comprazem
no imitado. Sinal disto é o que acontece na experiência: nós contemplamos com
prazer as imagens mais exatas daquelas mesmas coisas que olhamos com
repugnância, por exemplo, [as representações de] animais ferozes e [de] cadáveres.
Causa é que o aprender não só muito apraza os filósofos, mas também, igualmente,
aos demais homens, se bem que menos participem dele. Efetivamente, tal é o motivo
por que se deleitam perante as imagens: olhando-as, aprendem e discorrem sobre o
que seja cada uma delas, [e dirão], por exemplo, "este é tal”. (ARISTÓTELES,
1991a, p.203)

Assim, pode-se observar que o "momento de prazer não é interpretado como um desvio perigoso da essência, como em Platão, mas, pelo contrário, como um fator favorável, que estimula e encoraja o processo de conhecimento”. (GAGNEBIN, 1997, p.85) ${ }^{32}$

De igual modo, ao relatar o conhecimento, Aristóteles mostrava que este advém de um reconhecimento das imagens representadas, semelhantes às coisas existentes. É desse conceito de semelhança, já comentado anteriormente, que provém a teoria aristotélica da metáfora: “bem saber descobrir as metáforas significa bem se aperceber das semelhanças”. (ARISTÓTELES, 1991a, p.223)

Desse trecho, pode-se sublinhar que a metáfora estimula uma visão do semelhante, o que corrobora na defesa de uma mímesis avessa ao sentido de imitação ou repetição de um modelo. Esta semelhança adquirida é efeito de uma interferência sobre a imagem: "por meio

\footnotetext{
${ }^{31}$ A tradução de Eudoro de Souza faz corresponder o termo mimeisthai por "imitar" e derivados, o que pode gerar problemas no entendimento. Costa Lima (1995, p.68) vai se referir a isto em nota de pé de página, para justificar o porquê prefere a tradução francesa de Dupont-Roc e Laffot.

${ }_{32}$ Muitos comentadores ressaltam, como Gagnebin, com base nesta passagem de Aristóteles, que o reconhecimento da diferença provoca prazer. Para Costa Lima (2000, p.302), "o prazer de entender diminui a diferença, a qual se dissipa progressivamente à medida que cresce o entendimento". Assim, para ele, a mímesis, supõe "uma diferença, um prazer na diferença, que termina por afirmar uma identificação. A identificação, i.e., a internalização de uma semelhança, esconde a diferença de que partira”.
} 
do salto metafórico, a imagem abre outra cena para a verdade; é sua colaboradora e não a sua mera sombra”. (COSTA LIMA, 2000, p.36 - grifo do autor)

Porém, a semelhança não tem uma qualidade objetiva, concreta. Ela é o resultado do movimento da linguagem que transforma e cria semelhanças. A relação metafórica, portanto, acontece entre dois elementos da linguagem, do $\log _{0}{ }^{33}$.

A referência a logos provoca a lembrança da sua contraparte: o mythos. Como a mímesis, o mythos é associado à esfera prática, definido como reunião (synthesin) das ações completadas. (Cf. ARISTÓTELES, 1991a, p.206)

Ricoeur (1975, p.55-61) dedica uma maior atenção ao mythos. É em nome da afinidade que este reinstaura entre narrativa e drama, que o filósofo francês pôde reinscrever os conceitos da Poética em uma narratividade atual. (Cf. também Ricoeur, 1996, p.335)

O papel do mythos na criação poética é o de mímesis; isto é, é a “construção” do enredo que estabelece a mímesis. Se na tragédia se “imitam” ações de homens nobres; e na comédia, ações de homens inferiores (ARISTÓTELES, 1991a, p.262), o mythos não é apenas uma ordenação das ações humanas, mas uma composição em que prevalece uma restituição do humano mais nobre.

Neste sentido, Ricoeur aponta para o caráter de tensão da mímesis: por um lado, ela é, a um só tempo, "imitação” do humano e uma composição original; por outro, incide em uma restauração e em um deslocamento. É neste aspecto que encaminha a discussão a respeito da metáfora.

Tal metáfora, assim, ligada à mímesis, não pode mais ser concebida como um jogo gratuito.

Il faudrait se demander si le secret de la métaphore, en tant que déplacement de sens au niveau des mots, n'est pas dans la surélèvation de sens au niveau du muthos. S'il était permis de penser ainsi, la métaphore ne serait pas seulement un écart, l'instrument privilégié de la promotion de sens qui fait la mimêsis. (RICOEUR, 1983, p.58)

Sem a pretensão de um exame minucioso do corpus aristotélico e da vertical leitura empreendida por Ricoeur, ainda se faz necessário comentar dois aspectos antes de continuar o realce da concepção da metáfora como mímesis.

\footnotetext{
${ }^{33}$ Ricoeur (1975, p 22) rediscute a definição de logos: “On ne peut (...) pas traduire logos par phrase ou énoncé, mais seulement par locution, pour couvrir les deux domaines de la définition et de la phrase. La phrase n’a donc aucun privilège dans la théorie sémantique. Le mot, comme nom et comme verbe, reste l'unité decompte de la léxis"”.
} 
O primeiro é relembrar que a metáfora liga-se, por meio da lexis, à tragédia, ou melhor, à poética (poiesis) do drama trágico. A lexis (elocução ou expressão) é uma das seis partes da tragédia; as outras são: mythos (trama), ethe (caracteres ou personagens), dianóia (pensamento), opsis (espetáculo) e melopoiia (canto). Apesar de a katharsis não pertencer a esse segmento, é um elemento que participa do todo na definição:

\begin{abstract}
É pois a tragédia imitação de uma ação de caráter elevado, completa e de certa extensão, em linguagem ornamentada e com as várias espécies de ornamento distribuídas pelas diversas partes [do drama], [imitação que se efetua] não por narrativa, mas mediante atores, e que, suscitando o "terror e a piedade, tem por efeito a purificação dessas emoções”. (ARISTÓTELES, 1991a, p.205)
\end{abstract}

Por certo, no par mímesis-mythos cessa a atividade de composição da obra, da qual as seis partes contribuem para a organização e para a completude. Entretanto, o par mythoskatharsis associa o interior e o exterior da obra por meio da mediação da opsis, que faz perceber a ação representada. A katharsis não ocorre simplesmente por haver um mythos, mas sim porque "terror e piedade" resultam do processo mimético, isto é, derivam da purificação formal executada pelo poeta trágico. Dessa forma, o efeito trágico é similar à construção formal do mimema, pois a mímesis artística não depende do trabalho com as imagens, mas da configuração que elas alcançam. (Cf. COSTA LIMA, 2000, p.43)

Assim, vale reiterar que a mímesis forma um todo, no qual o mythos, o deslocamento da linguagem pela metáfora e a Katharsis possuem igual valor de importância para o espetáculo.

Ricoeur (1996, p.334) defende que é “a posição-chave da katharsis, na flexão da ação mimada pelo drama e do mundo práxico do espectador, que tornará possível o seu reemprego na escala de uma estética da recepção”34. (grifo do autor)

Todavia, ao se referir à ligação mímesis e mythos, é necessário pontuar o fato de que a mímesis é mímesis physeos. É este o segundo traço que merece ser destacado.

A expressão “imitação da natureza” tem por papel discernir tanto quanto coordenar o fazer humano e a produção natural ${ }^{35}$.

\footnotetext{
${ }^{34}$ Com efeito, Jauss (1979, p.43-61) caracteriza a experiência estética como aquela que comporta três categorias simultâneas e complementares: a poiesis, a aisthesis e a katharsis.

${ }^{35}$ De igual modo comenta Derrida (1972, p.283): "(...) la mimesis est posée en quelque sorte comme une possibilité propre à la physis. Celle-ci se révèle dans la mimesis, ou dans la poésie qui en est une espèce, en raison de cette structure peu apparente qui fait que la mimesis n'apporte pas de l'extérieur le pli de son redoublement. Elle appartient à la physis, ou, si l'on préfère, celle-ci comprend son extériorité elle-même et son double. La mimesis est donc, en ce sens, un mouvement 'naturel'". Em outro ensaio (“Economímesis”), Derrida,
} 
Aristóteles, nas diversas passagens em que utiliza o termo natureza, não o concebe como conceito operatório, mas nos limites de uma ciência da composição poética. É porque a “imitação da natureza” distingue o poético do natural que a referência à natureza não ocorre como uma determinação exercida sobre a composição da obra. É também porque a natureza possibilita o "fazer" da imitação que as ações humanas podem ser apresentadas como “melhores" ou "piores”, conforme o poema seja tragédia ou seja comédia: "La réalité reste une réference, sans jamais devenir une contrainte”. (RICOEUR, 1975, p.60)

Por outro lado, Ricoeur indaga se é pertinente traduzir physis por natureza, assim como é questionável verter mímesis por imitação. Para ele, o homem grego dificilmente identificaria a physis a algo inerte; ao contrário: por ser a própria natureza viva é que é possível representá-la.

Dessa forma, conclui que toda mímesis criadora se encontra no horizonte de um ser no mundo que ela torna manifesto na mesma medida em que a eleva ao mythos.

La vérité de l'imaginaire, la puissance de détection ontologique de la poésie, voilà ce que, pour ma part, je vois dans la mimêsis d'Aristote. C'est par elle que la lexis est enracinée et que les écarts mêmes de la métaphore appartiennent à la grande entreprise de dire ce qui est. Mais la mimêsis ne signifie pas seulement que tout discours est du monde. Elle ne préserve pas seulement la fonction référentielle du discours poétique. En tant que mimêsis phuseôs, elle lie cette fonction référentielle à la révélation du Réel comme Acte. (RICOEUR, 1975, p.61)

Quando Aristóteles (2005, p.269) expressou que a metáfora "pôr diante dos olhos (...) representa uma ação” e os homens podem ser apresentados “agindo” (ARISTÓTELES, 1991a, p.203); eis, segundo Ricoeur (1975, p.61), a possibilidade de ser esta a função ontológica do discurso metafórico, pois nele "tout potentialité dormante d'existence apparaît comme éclose, toute capacité latente d'action comme effective”.

Foi no estudo da função narrativa (Cf. Temps et récit, 1993) que Ricoeur, pela primeira vez, esboçou o problema da referência poética quando da ligação mímesis e mythos. A ficção narrativa "imita” a ação humana naquilo em que ela colabora para remodelar as suas estruturas e as suas dimensões, conforme a configuração imaginária da intriga. A ficção, assim, tem o poder de “redescrever a realidade”, que se constrói no texto como mundo. É este mundo do texto que interfere no mundo da ação para o configurar de novo, ou melhor, refigurá-lo.

a partir de Kant, retoma a questão da physis. Cf. NASCIMENTO, Evando. Derrida e a literatura. Rio de Janeiro: Editora da Universidade Federal Fluminense, 1999, p.318-26. 
A noção de mímesis, assim, conforme Ricoeur, funciona de modo dialético, primeiro como "imitação" e, em seguida, como reconstrução e, por fim, como habilidade transformadora da experiência.

A metáfora possibilita perceber o estabelecimento dessa intervenção de refiguração e entendê-la no conjunto das produções imaginativas (ficções), assim como permite apreender o encontro entre os dois momentos constitutivos da referência poética.

O primeiro deles é a "suspension du rapport direct du discours au réel déjà constitué, déjà décrit avec les ressources du langage ordinaire ou du langage scientifique”. O segundo é que o discurso poético traz à linguagem "des aspects, des qualités, des valeurs de la réalité, qui n’ont pas d'accès au langage directement descriptif et qui ne peuvent être dits qu'à la faveur du jeu complexe de l’énonciation métaphorique”. (RICOEUR, 1986, p.27-8)

A capacidade da metáfora de redescrever a realidade, dessa forma, é paralela à função mimética da ficção narrativa. Esta é exercida no espaço das ações e dos valores temporais; naquela, os traços sensoriais, estéticos e axiológicos fazem do mundo do texto, um mundo "habitável".

Em outras palavras: a função ontológica do discurso metafórico é o que o fez distinguir três etapas da mímesis - pré-figuração; configuração e refiguração ${ }^{36}$ - como o mundo da ação. Na mímesis como refiguração, em que o sentido metafórico traz uma nova referência, há a ligação do mundo do texto e do leitor, completado pelo ato de leitura. Como resume Benedito Nunes (1988, p.51):

Nas três fases da mímesis (...) a $1^{\text {a }}$ fase é aquela que está como imitatio, que começa
no âmbito da ação e da cultura, a montante da obra realizada, e, portanto,
retroativamente ligada ao real; a terceira, a jusante (en aval) da obra, vai na direção
do leitor, ambas têm como centro a segunda, chamada de configuração. O que em
Métaphore vive se dava como uma referencialidade que saía da tentativa de entender
o alcance da linguagem só por intermédio duma reinterpretação do discurso, o qual
sempre nos diz algo sobre alguma coisa, agora é dispensado por efeito da dinâmica
da leitura. É a dinâmica da leitura que cria a referencialidade no encontro entre o
contexto que a obra apresenta e o contexto do leitor. O leitor efetua, atualiza o
mundo da obra, assim realizando o seu enquadramento dentro da realidade que o
texto configurou e que foi capaz de alcançar.

Se por meio da metáfora se inicia um processo interpretativo; se ela desponta como resultante de um ato de leitura, a crítica literária pode servir-se do metafórico como ponto de partida ao penetrar no mundo do texto. Porém, caso a crítica assim proceda, cabe ainda

\footnotetext{
${ }^{36}$ Cf. item II.4.1. (Contrapontos), p.169-172. Costa Lima (1995, p.245) vai descrever, por outro lado, a crítica de Wolfgang Iser sobre as concepções de Ricoeur a respeito da mímesis.
} 
perguntar: de que forma isso ocorre? É o que se pretende discutir quando da análise da atividade crítica de Nunes. Porém, faz-se necessário, ainda, pontuar algumas teorias que lançaram luz ao problema do emprego da metáfora.

\section{III.1.2. O mundo do texto e o processo interpretativo: a metáfora em cena}

Como ressalta Eco (1991, p.188), “quando se parte de uma metáfora e se inicia um processo interpretativo, freqüentemente os limites entre leitura metafórica, leitura simbólica e leitura alegórica são muito imprecisos”.

De fato, nota Ricoeur (2000, p.57-8) que abordar a teoria da metáfora e a do símbolo ajuda a demarcar o campo para uma teoria da interpretação.

Alegoria, símbolo e metáfora são recursos há muito discutidos teoricamente. A alegoria "(grego allós = outro; agourein = falar) $\operatorname{diz} b$ para significar $a$. A Retórica antiga assim a constitui, teorizando-a como modalidade da elocução, isto é, como ornatus ou ornamento do discurso”. (HANSEN, 1986, p.1)

De um modo geral, a alegoria se divide em construtiva ou retórica, em que se valoriza a expressão, o modo de falar; e em interpretativa ou hermenêutica, cuja importância recai na interpretação. A primeira, assim, é designada de alegoria dos poetas e, a segunda, dos teólogos, preocupados com a maneira de entender o texto ${ }^{37}$.

A rigor, alude-se à alegoria uma história ou uma situação de sentidos duplos e figurados, mas que são facilmente compreendidos. O não uso da ambigüidade ou da plurissignificação aproxima a alegoria da parábola e da fábula, por ser freqüente o recurso da personificação.

Por outro lado, a ambigüidade ou a plurissignificação são características da metáfora, já que a sua leitura proporciona mais de um sentido.

O símbolo, por sua vez, é definido como maneira de expressão oposta à forma alegórica. Distinção esta que foi estabelecida principalmente no idealismo alemão e no Romantismo (Fichte, Hegel, Schelling, Herder, Schlegel, Creuzer). Para Goethe, o símbolo é a manifestação do geral ou universal no particular - por exemplo, a cruz para o Cristianismo.

\footnotetext{
${ }^{37}$ Para Santo Agostinho, a alegoria se encontrava nos acontecimentos históricos e não nas palavras. Em S. Tomás de Aquino, a alegoria não é concebida como artifício retórico, mas como visão do Universo. Cf. HANSEN (1986, p.51-3 e p.56-9).
} 
A crítica romântica “valoriza o símbolo porque, segundo ela, ele é orgânico e imediato, ao passo que a alegoria é mecânica e mediata, particular para o universal, exterior à ‘idéia’ expressa e constituída de vários momentos sucessivos”. (HANSEN, 1986, p.112 grifo do autor)

Vale lembrar que a diferenciação entre alegoria e símbolo é circunscrita ao Romantismo, posto que na tradição antiga, na greco-latina, na medieval e na renascentista não havia tal divisão.

No século XX, essa discussão é retomada por, entre outros, Lukács, Benjamim, Heidegger, Gadamer, Paul de Man e Ricoeur. Embora saiba que o assunto é amplo e complexo para ser abordado de maneira superficial e na forma de um itinerário, apenas citarei resumidamente estes autores, a título de exemplo, pois essa problemática não é o principal foco de interesse neste estudo.

Lukács $^{38}$ resgata a contenda romântica contra a alegoria "nos processos que moveu contra o expressionismo e outras vanguardas, bem como contra Kafka ${ }^{39}$, Joyce, Beckett”, pois a julga "um modo inferior e superado de formar - ela é própria das artes da Transcendência, isto é, das artes cujo sentido está dado fora delas, na Eternidade”. (HANSEN, 1986, p.8) Segundo ele, o artista contemporâneo é formalista quando alegorizante, porque produz uma forma vazia, sem correspondência com o mundo real.

Já para Walter Benjamin, em Origem do drama barroco alemão (1984), ${ }^{40}$ a alegoria é concebida como aquela que pode revelar uma verdade oculta e que é "no reino dos pensamentos o que são as ruínas no reino das coisas”. (BENJAMIN, 1984, p.200). No drama barroco, a alegoria mostra a visão da finitude do homem no absurdo do mundo. Na visão moderna, presente na obra de Baudelaire, o procedimento alegórico deixa de ser uma transposição do oculto para ser uma "possibilidade de, na linguagem do poema, insinuar a consciência de sua historicidade”. (BARBOSA, 1986, p.21)

Como método de escrita e de crítica, Benjamim apresenta a alegoria como o "outro" da História:

Lendo no 'outro' da alegoria o reprimido da História, ele não consegue encontrar sua expressão através dos dominados, mas só através dos dominadores. Se o

\footnotetext{
${ }^{38}$ Cf. LUKÁCS, G. Realismo crítico hoje. Trad. Erminio Rodrigues. Brasília: Coordenada-Editora de Brasília Ltda., 1969.

${ }^{39}$ A respeito da alegoria e do símbolo em Kafka Cf. ANDERS, Günther. Kafka: pró \& contra - os autos do processo. Trad. Modesto Carone. São Paulo: Cosac \& Naify, 2007, p.55-70.

${ }^{40}$ Cf. BENJAMIN, Walter. Origem do drama barroco alemão. Trad. Sergio Paulo Rouanet. São Paulo: Brasiliense, 1984.
} 
Trauerspielbuch (Origem do drama barroco alemão) havia descoberto na figura de Richard III de Shakespeare uma alegoria disfarçada da maldade, o Trabalho das Passagens desvendará as litanias baudelairianas a favor de Satã e de Caim como uma definição inconsciente a favor do proletariado, representado prototipicamente naquelas figuras por parte dum Poeta não pertencente àquela classe. Por outro lado, aquela encarnação da 'maldade' guardaria sub-repticiamente os traços da visão dos próprios dominadores. Benjamin insiste em Baudelaire como um poeta de visão alegórica e alegorizante. (KOTHE, 1976, p.36)

Em A origem da obra de arte, Heidegger (1992, p.13) assinala que a natureza da obra de arte é característica de uma realidade alegórico-simbólica indivisível:

\begin{abstract}
A obra de arte é, com efeito, uma coisa, uma coisa fabricada, mas ela diz ainda algo de diferente do que a simples coisa é, “allo agoreuei”. A obra dá publicamente a conhecer outra coisa, revela-nos outra coisa; ela é alegoria. À coisa fabricada reúnese ainda, na obra de arte, algo de outro. Reunir-se diz-se em grego symballein. A obra é símbolo. Alegoria e símbolo fornecem o enquadramento em cuja perspectiva se move desde há muito a caracterização da obra de arte. Só essa unidade na obra, que revela um outro, essa unidade, que se reúne com algo de outro, é que é o elemento coisal na obra de arte.
\end{abstract}

Gadamer (2002, p.132 e s.s.), por sua vez, em Verdade e Método, valoriza o símbolo, já que entende a alegoria dentro de uma estética que se recusa a diferenciar a experiência da representação dessa experiência. O símbolo é visto no seu poder de levar a um significado de caráter indefinido e universal; ao contrário da alegoria, que se refere a um significado específico, que se esgosta em si mesmo. Símbolo e alegoria opõem-se da mesma forma que a arte se opõe à não-arte: o primeiro se estabelece em uma unidade íntima entre a imagem que emerge nos sentidos e a totalidade supra-sensorial que essa imagem indica; a segunda desponta como racional e dogmática na sua referência a um significado que não é por si instituído.

A contribuição de Paul de Man para os estudos da alegoria, do símbolo e da metáfora são particularmente presentes no capítulo “The rhetoric of temporality”, de Blindness and insight: essays in the rhetoric of contemporary criticism (1988) e no livro Allegories of reading: figural language in Rousseau, Nietzsche, Rilke and Proust (1979) ${ }^{41}$, em que apresenta suas próprias leituras como alegoria.

Para ele, esta se refere a um significado específico e se distancia em relação à sua própria origem. O símbolo é a possibilidade de uma identidade ou identificação como expressão da unidade entre as funções semânticas e representativas da linguagem e a metáfora

\footnotetext{
${ }^{41}$ Cf. MAN, Paul de. Blindness and insight: essays in the rhetoric of contemporary criticism. $2^{\mathrm{a}}$ ed. Minneapolis: University of Minnesota Press, 1988; e Allegories of reading: figural language in Rosseuau, Nietzsche, Rilke and Proust. New Haven: Yale University Press, 1979.
} 
é considerada como aquela que promove uma dialética entre objeto e sujeito, ao qual a experiência do objeto se faz de uma percepção ou de uma sensação.

Por fim, Paul Ricoeur dedica um capítulo da sua Teoria da Interpretação (2000) à metáfora e ao símbolo. A teoria dos símbolos, já explorados em vários dos seus escritos (por exemplo, a respeito da psicanálise, da religião), completa a da metáfora, interessado que está na questão da interpretação.

Ricoeur (2000, p.65) começa por esclarecer que os símbolos possuem um caráter lingüístico (teoria que explicaria a sua estrutura em termos de sentido ou de significação) e não-lingüístico (a sua complexidade externa que o vincula aos variados campos de pesquisa).

Por conta dessa complexidade, estuda-o em três passos: 1. identifica o núcleo semântico do símbolo, com base na ordem do sentido produtivo nas expressões metafóricas; 2. por meio de um método de contraste e possibilitado pelo funcionamento metafórico da linguagem, isola a camada não-lingüística dos símbolos; 3. de posse de uma nova compreensão dos símbolos, tenta elucidar a metáfora.

Nesses caminhos, chega, porém, a duas conclusões contrárias acerca da relação entre metáfora e símbolos: há mais na metáfora do que no símbolo e há mais no símbolo do que na metáfora: Há mais metáforas do que símbolos, no sentido de que ela traz à linguagem a
semântica implícita do símbolo, o que permanece confuso no símbolo - a
assemelhação de uma coisa a outra e de nós às coisas; a infinda correspondência
entre os elementos - é clarificado na tensão da enunciação metafórica. Mas há mais
no símbolo do que na metáfora. A metáfora é o procedimento linguístico - forma
bizarra de predicação - dentro do qual se deposita o poder simbólico. O símbolo
permenece um fenômeno bidimensional na medida em que a face semântica se
refere à não semântica. O símbolo está ligado de um modo não presente na metáfora.
Os símbolos têm raízes. Os símbolos mergulham na experiência umbrosa do poder.
As metáforas são precisamente a superfície lingüística dos símbolos e devem o seu
poder de relacionar a superfície semântica com a superfície pré-semântica nas
profundidades da experiência humana à estrutura bidimensional do símbolo.
(RICOEUR, 2000, p.80-1)

Antes de se avançar na reflexão, cumpre notar que nem sempre o uso do recurso metafórico era unânime. Restrita ao literário ou a obras de natureza não-conceitual, longe da exposição de um cientista ou de um filósofo, a metáfora já recebeu críticas contundentes, como a do lingüista Charles Bally ${ }^{42}$, comentada por Costa Lima (1989, p.126-7).

\footnotetext{
${ }^{42}$ Cf. BALLY, Charles. Traité de stylistique française. 2 vols. Paris : Georg-Librairie Klincksieck, 1951.
} 
Ted Cohen (In: SACKS, 1992, p.10-1) recorda o caso paradigmático de Hobbes e Locke $^{43}$, de muitos filósofos positivistas do século XX e de outros que as consideravam "frívolas e secundárias, quando não perigosas e logicamente incorretas, negando-lhes (1) qualquer capacidade de conter ou transmitir conhecimento; (2) qualquer conexão direta com os fatos; ou (3) qualquer significado real”.

Se é relativamente recente a importância dada ao metafórico, por outro lado, é significativo o número de pesquisas, congressos, ensaios breves e publicações especializadas a seu respeito.

Em um estudo que se pretende panorâmico, faz-se imprescindível, pelo menos, salientar alguns exemplos de obras e de linhas investigativas em que o metafórico ganha relevância. Exemplos colhidos em um vasto campo que, longe de se esgotar, é matéria presente em diferentes áreas do pensamento. O critério de escolha ${ }^{44}$, portanto, foi pinçar os mais conhecidos e próximos ao domínio da crítica literária.

O primeiro livro que se pode citar é Rhétorique générale (1970) do groupe $\mu^{45}$. Neste, há a retomada das questões retóricas, aproximadas à poética, e as discussões permitem rever conceitos, como o da função poética ${ }^{46}$ de Jakobson. A proposta pelo grupo resume-se a mostrar que a metáfora não é considerada propriamente uma substituição de sentido, ou transferência do nome, mas uma modificação do conteúdo semântico de um termo. Ela é, pois, resultante de um rearranjo da estrutura sêmica, mais especificamente, de duas intervenções complementares, uma de adição, outra de supressão de semas. Ou seja, a metáfora é composta de duas sinédoques ${ }^{47}$.

Igualmente relevante é a explanação de Iuri Tinianov (1975, p.29) a respeito da importância da figura da metáfora na composição do verso: “a vitalidade da metáfora é diretamente ligada à presença de um indício fundamental”.

\footnotetext{
${ }^{43}$ Cf. respectivamente HOBBES. Da linguagem (Primeira parte - Cap.IV do Leviatã). In: Os pensadores. Trad. João Paulo Monteiro e Maria Beatriz N. da Silva. São Paulo: Nova Cultural, 1997, p.43-9; e LOCKE. O abuso das palavras (Livro III - Cap.X do Ensaio acerca do entendimento humano). In: Os pensadores. Trad. Anoar Aiex. São Paulo: Nova Cultural, 1991, p.124-7. Em “A epistemologia da metáfora”, Paul de Man (In: SACKS, p.19-34) faz uma interessante leitura desse texto de Locke.

${ }^{44}$ Toda seleção, como se sabe, é uma tarefa árdua e, por vezes, deixa ao largo importantes contribuições ao assunto. O recorte privilegia apenas o aspecto crítico da metáfora, como já discutido, por exemplo, por João Alexandre Barbosa em "Exercícios de definição". Cf. A metáfora crítica. São Paulo: Perspectiva, 1974, p.9-46.

${ }^{45}$ Groupe $\mu$ : Centre d'etudes poétiques, Université de Liége: J. Dubois, F. Edeline, J. M. Klinkenberg, P. Minguet, F. Pire e H. Trinon.

${ }^{46}$ Segundo Jakobson (1975, p.130), a função poética nasce da projeção "do princípio de equivalência do eixo de seleção sobre o eixo de combinação". (grifo do autor).

${ }^{47}$ Eco (1991, p.148-152) exemplifica e comenta a teoria da metáfora proposta pelo groupe $\mu$ em contraponto à teoria da tradição aristotélica.
} 
Para Tinianov, o indício fundamental do significado é uma categoria de unidade lexical, que se diferencia do indício secundário de significado, ou flutuante. Ou seja: nos poemas, percebe-se um jogo entre os distintos traços de significado de uma palavra. A citação, mesmo breve, põe em relevo as linhas gerais da problemática discutida:

Um (...) deslocamento do indício fundamental dá sempre margem a uma tensão
semântica; mas esta tensão semântica nasce só de uma parcial eliminação do indício
fundamental; para que a metáfora seja reconhecida como vital, é necessário que nas
palavras se perceba seu indício fundamental, mas justamente nesta insuficiente e
deslocada presença. Se faltar este elemento de eliminação, se a "luta" faltar, a
metáfora morre, banaliza-se, torna-se elemento de língua. (p.29)

Pode-se, ainda, lembrar da ligação da metáfora com o mito - como em Cassirer $^{48}$-; com a psicanálise - conceito de condensação ${ }^{49}$-; com a concepção lingüística de Lakoff e Johnson $^{50}$; com a semiótica de Peirce ${ }^{51}$; com as reflexões contemporâneas de, entre outros, Hannah Arendt, Max Black, Hedwig Konrad e I. A. Richards ${ }^{52}$; e com as questões filosóficas, centradas principalmente em Nietzsche, Derrida e Heidegger, que foram debatidas a contento por Ricoeur (1975), na já citada obra La métaphore vive, e as quais este trabalho privilegia como norte para se discutir a função da crítica.

Porém, como acentua Eco (1991, p.168), “uma incursão mesmo que rápida (e por momentos de ruptura da episteme) na história da metaforologia não deve deixar de lado Vico”.

De fato, em Scienza Nuova (1725), Giambattista Vico ${ }^{53}$ valoriza a linguagem tropológica como a primeira linguagem, original, ao dispor da humanidade. A metáfora, assim, na sua concepção, assume uma outra característica, recuperada, por assim dizer, do estatuto de ornato, do bem falar, imposto pela Antigüidade latina - como nas Institutiones, de

\footnotetext{
${ }^{48}$ Cf. CASSIRER, Ernst. O poder da metáfora. In: Linguagem e mito. $3^{\text {a }}$ ed. Trad. J. Guinsburg e Miriam Schnaiderman. São Paulo: Perspectiva, 1992.

${ }^{49}$ A condensação e o deslocamento, elementos básicos do funcionamento do inconsciente notado por Freud, vão ser relacionados às figuras da metáfora e da metonímia respectivamente, em um estudo sobre a afasia feito por Roman Jakobson. Lacan, por sua vez, aproxima da metonímia, o desejo, e da metáfora, o sintoma. A partir daí, afirma ser o "inconsciente estruturado como uma linguagem". Cf., entre outros, LACAN, Jacques. Ecrits. Paris: Éditions du Seuil, 1966.

${ }^{50}$ Cf. LAKOFF, George e JOHNSON, Mark (1980). Metaphors we live by. Chicago: The University of Chicago Press, 1980. No Brasil, o livro A metáfora (org. de Eunice Pontes. Campinas: Editora da UNICAMP, 1990) reúne textos sobre a metáfora estudados na perspectiva lingüística com base no trabalho desses autores.

${ }^{51}$ Para Peirce, a metáfora é um ícone de terceiro nível, um hipoícone, que "representa um caráter representativo de um representâmen através da representação de um paralelismo com alguma outra coisa”. Cf. PEIRCE, Charles S. Semiótica. $2^{\mathrm{a}}$ ed. Trad. Teixeira Coelho. São Paulo: Perspectiva, 1990, p.64.

${ }^{52}$ Cf. respectivamente HANNAH, Arendt. The life of the mind. New york: Harcourt Brace, 1978; BLACK, Max. Models and metaphors. New York: Cornell University Press,1962; KONRAD, Hedwig. Étude sur la métaphore. Paris: J. Vrin, 1958; e RICHARDS, I. A. The philosophy of rhetoric. Oxford: Oxford University Press, 1964.

${ }^{53}$ A respeito de Vico Cf. BOSI, Alfredo. Uma leitura de Vico. In: O ser e o tempo da poesia. São Paulo: Cultrix/ Editora da Universidade de São Paulo, 1977, p.193-220.
} 
Quintiliano - e pelos estudos clássicos do Renascimento, que também não tiveram a preocupação de considerá-la como forma de conhecimento.

Para Vico, a linguagem emanava da imaginação do poeta, que encontrava semelhanças entre a voz nomeante e a coisa nomeada. Diferente, portanto, da noção da origem da linguagem adâmica, que aludia ao contato direto da divindade com o homem, pelo qual a nomeação das coisas se realizava em concordância com a própria natureza destas. A linguagem hieroglífica, “divina”, “sagrada”, não era outorgada por Deus aos homens, senão que os homens criavam esse Deus.

Dessa forma, o "primeiro falante” era um inventor de uma fala fantástica e a fonte da lógica humana não era divina, mas poética ${ }^{54}$.

Esta lógica poética tinha na metáfora a figura por excelência. Na Scienza Nuova, esta tinha como função dar sentido e paixão às coisas insensatas, de tal sorte que o "processo inerente à formação das mais belas metáforas [era] o da narração” (BOSI, 1977, p.212), o que a aproxima de uma breve fábula.

Vincular, no entanto, a importância da metáfora a uma fase poética primitiva, constitui, em contraparte, uma problemática, pois "não sabemos o que fazer com ela no tempo da 'prosa do mundo'”. (COSTA LIMA, 1989, p.160) Em outros termos: se Vico reservava ao campo da metáfora os tempos remotos, Nietzsche ${ }^{55}$, por exemplo, salientava a natureza metafórica dos signos, tanto na dimensão originária quanto no presente. A conseqüência disto era que o filósofo alemão, ao tentar explicar a origem da linguagem por meio da metáfora, especialmente em O livro do filósofo (1984), punha em evidência a dificuldade de se conhecer a verdade das coisas:

(...) as diferentes línguas mostram que pelas palavras nunca conseguimos chegar à verdade, nem a uma expressão adequada: a não ser assim, não existiriam tão numerosas línguas. A “coisa em si” (que seria precisamente a verdade pura sem conseqüências), mesmo para quem desse forma à língua, é totalmente inatingível e não vale portanto, os esforços que exigiriam. Só designa as relações das coisas aos homens com a ajuda das metáforas mais astuciosas para a sua expressão. Primeiramente transpor uma excitação nervosa para uma imagem! Primeira metáfora. A imagem de novo transformada num som articulado! Segunda metáfora (...). Acreditamos que sabemos alguma coisa das próprias coisas quando falamos de árvore, de cores, de neve e de flores e, no entanto, só temos metáforas das coisas, que não correspondem de forma alguma às entidades originais. (NIETZSCHE, 1984, p.92-3)

\footnotetext{
${ }^{54}$ Croce chega a afirmar que Vico fundou a Estética moderna, pois foi capaz de ressaltar a particularidade da fantasia, da intuição poética e aproximar as origens da poesia às origens das línguas. Cf. CROCE, Benedetto. $L a$ filosofia di Giambattista Vico. Bari: Laterza, 1933.

${ }^{55}$ Acerca da metáfora em Nietzsche Cf. Kofman, Sarah. Nietzsche et la métaphore. Paris: Payot, 1972.
} 
Pode-se ressaltar dessa passagem o fato de que a impossibilidade de o homem ter acesso à “coisa em si”, o faz condenado à mentira e à ilusão ${ }^{56}$, ao não-conhecimento, já que a linguagem é originada por uma trama intrincada de metáforas: da excitação nervosa à imagem, e desta ao som. A linguagem nasce, portanto, de uma maneira ilógica e é o resultado de relações arbitrárias.

Neste processo de constituição da linguagem, o conceito, para Nietzsche, é decorrente do nascimento e do uso da língua, da "identificação do não idêntico". (NIETZSCHE, 1984, p.93) A conceitualidade filosófica, assim, "se vê (...) desacreditada em seus fundamentos” e a metáfora “comparece como função primacial da linguagem na falta de um instrumento mais adequado”. (NASCIMENTO, 1999, p.329)

São metáforas que ocultam sentidos, esquecidas no conceito intemporal:

As verdades são ilusões que nós esquecemos que o são, metáforas que foram usadas e que perderam a sua força sensível, moedas que perderam o seu cunho e que a partir de então entram em consideração, já não como moeda, mas apenas como metal. (NIETZSCHE, 1984, p.94)

Esta reflexão que Nietzsche desenvolve acerca da linguagem em geral, e da metáfora, em particular, influencia não poucos autores. Derrida, por exemplo, em La mythologie blanche (1972, p.312) ${ }^{57}$, alude ao nome do autor do Livro do filósofo como um exemplo categórico “pour figurer la métaphoricité du concept, métaphore de la métaphore, métaphore de la productivité métaphororique elle-même”.

Tal como Nietzsche, Derrida comenta a questão da metáfora no “texto metafísico”, e fundamenta sua análise na oposição entre o inteligível e o sensível, o próprio e o impróprio; temas que são também discutidos no Livro do Filósofo.

Derrida menciona uma passagem deste livro de Nietzsche em que este aproxima a atividade da abelha à atividade filosófica. Esta metáfora pode sugerir conceder o mesmo valor ao trabalho de um e de outro, assim como também aponta a tentativa de diminuição do mundo

\footnotetext{
${ }^{56}$ Ao ter consciência da mentira e da ilusão da linguagem, o homem, no entanto, pode aceitar e se comprazer com a arte: "a arte possui a alegria de acordar das crenças através das superfícies: mas não somos enganados! Senão a arte acabaria. (...) A arte trata (...) a aparência enquanto aparência, logo não quer enganar, é verdadeira". (NIETZSCHE, 1984, p.108 - grifo do autor)

${ }^{57}$ No texto "Le retrait de la métaphore" (In: Psyché. Paris: Galilée, 1998), Derrida retoma a discussão, iniciada em La mythologie blanche, "para reforçar ainda mais o valor diferencial da metáfora. Como o heterônimo différance - a metáfora é o que subtrai, se re-tira da cena do mundo, e nesse retirar-se cria-se a história do Ocidente como época do ser ou, agora se pode dizer, como 'época da metáfora' que se retirando abre o campo da história como realização teleológica do encontro da presença consigo mesma. A metáfora é o índice de um traço (trait) que se faz re-traço (re-trait) e nessa retirada (retrait) perfaz-se a história do Ocidente como rendição ou redenção (relève, Aufhebung) do traço original, dividido, ir-representável”. (NASCIMENTO, 1999, p.324-5)
} 
ao conteúdo alocado nos casulos: "Em virtude de ser um gênio da arquitetura, o homem eleva-se muito acima da abelha: esta constrói com a cera que recolhe da natureza, ele com a matéria bem mais frágil dos conceitos que apenas deve fabricar a partir dele próprio”. (NIETZSCHE, 1984, p.96)

O filósofo, portanto, só é capaz de encontrar aquilo que ele mesmo produziu; verdades abstratas que se cristalizam como preconceitos em relação ao mundo. É desta forma que a linguagem conceitual torna-se uma metáfora que "perde” seu princípio de cor, de instinto, de natural e se transforma em "metáfora branca": "Mythologie blanche - la métaphysique a effacé en elle-même la scène fabuleuse qui l'a produite et qui reste néanmoins active, remuante, inscrite à l'encre blanche, dessin invisible et recouvert dans le palimpseste”. (DERRIDA, 1972, p.254)

Assim, o argumento de Nietzsche que Derrida “desloca (obviamente a partir de inúmeras leituras dos textos posteriores de Nietzsche, contra ele mas sobretudo graças a ele) e generaliza n' ‘A mitologia branca' é o de que o conceito é uma metáfora desgastada”. (NASCIMENTO, 1984, p.330)

Tanto para Derrida quanto para Paul de $\mathrm{Man}^{58}$, não há interesse em criar um novo conceito de metáfora, mas de lê-la como presente na estrutura da linguagem. Neste sentido, descrevem a lógica paradoxal que há em qualquer tentativa de definição:

A metáfora dá a totalidade que então afirma definir, mas é, na verdade, a tautologia de sua própria posição. O discurso das idéias simples é um discurso figurado ou tradução e, como tal, cria a ilusão falaciosa de definição (MAN In: SACKS, 1992, p.23).

Para Paul de Man, a metáfora, como figura retórica, subverte as certezas do saber e da compreensão, por isso é algo não confiável na linguagem. Sua leitura, portanto, planeja investigar o rhetorical motion dos textos, não com a intenção de classificá-los ou descrevêlos, mas simplesmente para evidenciá-los e focalizar a impossibilidade da demarcação dos tropos com relação a outras formas verbais, tal como pensa Derrida.

Ao comentar sobre os textos de tradição epistemológica do século XVIII, de Locke, Condillac e Kant, Man (In: Sacks, 1992, p.33) ironiza a possibilidade de se criar uma epistemologia da metáfora:

\footnotetext{
${ }^{58}$ Autor em que também a voz de Nietzsche é ouvida e reiterada. Em Allegories of reading - figural language in Rosseau, Nietzsche, Rilke and Proust (1979, p.79-131), estuda a gênese e a genealogia de Nietzsche, bem como a sua retórica de tropos e da persuasão.
} 
Meu principal objetivo foi acentuar a futilidade de se tentar reprimir a estrutura retórica dos textos em nome de modelos textuais preconcebidos e inquestionados, como teleologias transcendentais ou, do outro lado do espectro, meros códigos.

Em última instância, verifica-se que Nietzsche intenta “decifrar a função determinante dos espaços vazios no discurso metafísico, o que, concomitantemente, traz à luz a eficácia própria da metáfora morta, enquanto dissimulação do processo metafórico”. (BRANCO In: NIETZSCHE, 1984, p.19)

Ora, como Branco (In: NIETZSCHE, 1984, p.19) acentua, é contra esta metáfora morta defendida por Nietzsche e retomada por Derrida que Ricoeur (1975, p.382) ${ }^{59}$ argumenta: apagar o traço da metáfora que originou o conceito cria, nesse mesmo gesto, uma “ordre conceptuel [qui] est capable de s'affranchir du jeu de la double signification, donc du dynamisme sémantique caractéristique de l'ordre métaphorique”. O sentido do conceito "ne se réduit aucunement à son schème. Ce qui est précisément à penser, c’est que l'abandon du sens sensible ne donne pas seulement une expression impropre, mais une expression propre de rang conceptuel”. (p.371)

Também em I. A. Richards encontramos traços da reflexão nietzscheana, como o equívoco da distinção entre sentido próprio e figurado, já que ambos qualificam a linguagem como essencialmente metafórica.

Richards é considerado "o primeiro autor contemporâneo que começou a revolucionar o tratamento da metáfora”60 (COSTA LIMA, 1989, p.164)

A contrapartida ao estudo clássico da metáfora, em que o nome é a unidade de referência, foi a teoria que deslocou a significação da palavra para o quadro da frase. É esse o ponto a que Richards alude, ao mostrar que a metáfora só é possível como interação dentro do interior de uma proposição. Portanto, o metafórico passa a ser um enunciado de predicação, não mais concebido como um desvio, mas como um “enunciado impertinente”.

\footnotetext{
59 Aqui também Ricoeur (1975, p.365) discute a respeito da afirmação de Heidegger “o metafórico só existe no interior da metafísica”: “En effet, la 'relève’ par laquelle la métaphore usée se dissimule dans la figure du concept n'est pas un fait quelconque de langage, c'est le geste philosophique par excellence qui, en régime 'métaphysique', vise l’invisible à travers le visible, l’intelligible à travers le sensible, après les avoir séparés. Il n’y a donc qu’une 'relève'; la 'relève’ métaphorique est aussi la 'relève’ métaphysique. Acerca da referência à metáfora em Heidegger Cf. NUNES, Benedito. O novo começo. In: Passagem para o poético, p.289-294.

60 Para Massaud Moisés, “dentre as teorias modernas acerca da metáfora, a de I. A. Richards tornou-se amplamente conhecida e difundida, razão pela qual é indispensável como ponto de partida de qualquer interpretação a respeito”. Cf. MOISÉS, Massaud. Dicionário de termos literários. São Paulo: Cultrix, 2004, p.328.
} 
Neste sentido, a metáfora é investigada no seu valor semântico, posto que a frase já possui uma significação mínima completa. Émile Benveniste ${ }^{61}$ vai mostrar que essa reflexão se opõe à semiótica, que entende a palavra como um signo em um código lexical. Ao preferir o termo "instância do discurso", contra a imanência da língua, Benveniste defende que é a intenção e não o significado, que tem alcance exterior à linguagem, com o qual, completa Ricoeur (1975, p.98),

la fonction de transcendance de l'intenté recouvre parfaitement le concept fregéen de référence. En même temps, est pleinement justifiée l’analyse phénoménologique de Husserl basée sur le concept d'intentionnalité: la langage est par excellence intentionnel, il vise l'autre que lui-même.

No entanto, Paul Ricoeur (1975, p.154) conjuga essas duas vertentes - a semiótica e a semântica - para provar que se a palavra é o foco de interesse, esta necessita da frase como quadro de articulação. Combinar as duas teorias possibilita conceber tanto uma definição real quanto uma nominal (leibniziana) da metáfora, ou seja, tanto da transferência do nome quanto da produção metafórica como processo de formação desta.

É no âmbito da semântica que I. A. Richards ${ }^{62}$ explora a aproximação aparentemente impossível de dois termos, que ele denomina tenor e vehicle, por uma relação de similaridade, o que faz emergir daí uma significação nova. Na verdade, segundo Ricoeur (1975, p.100), ele vincula a metáfora à definição de uma nova retórica.

Esses termos, aliás, ajudam a explicar a questão da metáfora in praesentia e in absentia na retórica clássica:

a) in praesentia: tenor e vehicle estão presentes no enunciado, e o papel do leitor reside em descobrir o que há de comum entre os dois [metáfora de uso]. Ex. “Qualquer trabalho (tenor) é mortificação cotidiana (vehicle)”. (Benedito Nunes)

b) in absentia: o vehicle está presente, e o tenor, ausente. O leitor deve descobrir o tenor e o que constitui a similaridade entre ele e o vehicle [metáfora de invenção]. Ex. "Os chocolates em túnica de prata”. (Carlos Drummond de Andrade) ${ }^{63}$

\footnotetext{
${ }^{61}$ Cf. BENVENISTE, Émile. Problèmes de linguistique générale. Paris: Gallimard, 1976. Cf. também Ricoeur (1975, p.88-100).

${ }^{62}$ Notadamente em The philosophy of rhetoric. Oxford University Press, 1964. (obra já citada na nota 52,p.204)

${ }^{63}$ Este exemplo é discutido por Mara Sofia Z. de Paschoal no texto "Em busca da elucidação do processo de compreensão da metáfora”: “túnica de prata (...) constitui ela própria o veículo [vehicle], sendo que o teor [tenor] e a base da similaridade devem ser descobertos pelo leitor. O teor é 'papel laminado que envolve os bombons', e a base da similaridade está na função de envolver, vestir. Na interação entre teor e veículo, este acaba atribuindo ao papel laminado e aos chocolates que são por ele envolvidos, o traço/+ humano/, ou seja, acarreta uma
} 
Em Richards, o enunciado metafórico, assim, designa uma nova significação com base na ação contextual e a esta é "conferido um estatuto de acontecimento; se, pela metáfora, o mundo é projetado e revelado, ela tem um duplo papel de sentido e acontecimento”. (BRANCO In: NIETZSCHE, 1984, p.12)

Como sublinha Ricoeur (1975, p.109), a obra de Richards abre caminho para outros que se preocuparam com a análise semântica da metáfora; entre eles, Max Black ${ }^{64}$.

De fato, o par conceitual tenor/vehicle, de Richards, recebe uma nova terminologia de Black: respectivamente focus, para designar a palavra metafórica, e frame, para indicar o restante da frase. O emprego metafórico do focus é o resultado da relação entre ele e o frame, isto é, o contexto. A nova terminologia, contudo, não é gratuita: se Richards "procurava entender a metáfora em termos de diferença de planos (...), Black se contenta em pensar com as relações in praesentia na frase, apenas distinguindo seus componentes por seu grau de 'luminosidade’”. (COSTA LIMA, 1989, p.168)

Para Black, o processo metafórico vai além da substituição; exige-se, pois, uma visão interacional do leitor, uma vez que ele precisa estar consciente da amplitude do significado; isto é, deve buscar compreender o velho e o novo sentido em conjunto: "O condutor do sentido metafórico não é mais a palavra, mas a sentença como um todo”. (RICOEUR, 1992, p.147)

A teoria da interação - interação esta que ocorre entre o sentido indivisível do enunciado e o sentido focalizado da palavra - é contraposta às teorias clássicas da metáfora: a substitutiva e a comparativista.

Por teoria substitutiva, Black entende empregar uma expressão não-habitual no lugar de uma expressão literal. Como explica Ricoeur (1975, p.111):

\footnotetext{
si la métaphore est une expression substituée à une expression littérale absente, ces deux expressions sont équivalentes; on peut donc traduire la métaphore par le moyen d'une paraphrase exhaustive; dès lors, la métaphore ne comporte aucune information.
}

\footnotetext{
personificação dos chocolates”. (p.120-1) In: PONTES, Eunice (org.). A metáfora. Campinas: Editora da UNICAMP, 1990, p.115-128.

${ }^{64}$ Cf. BLACK, Max. Models and metaphors. New York: Cornell University Press, 1962. (obra já citada na nota 52, p.204)
} 
Já a teoria da comparação é um traço particular da substituição, pois especificar o fundamento de uma analogia é determinar uma comparação literal, que é considerada equivalente ao enunciado metafórico e que pode, portanto, ser por ela substituída.

Porém, ao assinalar uma visão interacionista da metáfora, Black afirma que há casos em que o uso metafórico poderá ser de natureza não-constitutiva, isto é, ornamental. Isto porque, há metáforas que somente são explicáveis por uma estrutura de substituição; no entanto, só aquelas que são constitutivas, que necessitam de uma visão interacionista, é que são importantes para a filosofia.

Aproximar a metáfora de modelos científicos (isto é, aqueles que agem por analogia e os que operam através e por meio de uma analogia implícita), possibilita a Black um olhar diferenciado:

ao invés de apenas dar mais elementos para a revalorização da metáfora ou de limitá-la a campos previamente aceitáveis ou previsíveis - os da vida diária, da literatura ou das ciências 'imaturas' - o autor avança sobre o território das ciências 'duras' e, indiretamente, põe em xeque os pressupostos substancialistas que lhes têm servido de respaldo. (COSTA LIMA, 1989, p.170)

Ricoeur (1975, p. 125) acrescenta ainda o nome de Monroe Bearsley ${ }^{65}$ para dar prosseguimento à explicação da metáfora no âmbito semântico, pois este, ao conceder ao absurdo lógico um papel importante, ressalta o caráter de invenção e de inovação do enunciado metafórico. A oposição, assim, entre sentido figurado e sentido próprio ganha outro relevo:

La collision sémantique qui contraint à un déplacement da la désignation à la connotation donne à l'attribution métaphorique non seulement un caractère singulier mais un caractère construit; il n'ya pas de métaphore dans le dictionnaire, il n'en existe que dans le discours; en ce sens, l'attribution métaphorique révèle mieux que tout autre emploi du language ce que c'est qu'une parole vivante; elle constitue par excellence une « instance de discours ».

Os variados conceitos das teorias interacionistas da metáfora permitiram a Ricoeur apreender as principais características no discurso:

substituição da teoria retórica da substituição por uma teoria propriamente semântica da interação entre campos semânticos; reconhecimento da importância da polarização semântica tendo como limite o absurdo lógico; emergência de uma partícula de sentido que se difunde por toda a sentença. (NUNES, [Jordão], 2000, p.165)

\footnotetext{
${ }^{65}$ Cf. BEARSLEY, Monroe. Aesthetics. New York: Harcourt, Brace and World, 1958.
} 
É necessário lembrar, ainda, que Ricoeur estabelece as bases de sua teoria da metáfora com o apoio do esquematismo kantiano. Por esquema, entendia Kant uma representação intermediária que, “por um lado, é homogênea com a categoria e, por outro lado, é homogênea com a aparência (dados sensíveis), o que torna a aplicação da primeira à última possível”. (NUNES, [Jordão], 2000, p.127-8) O esquema é, em outras palavras, a forma em que a imaginação orienta o entendimento na construção de imagens. Essa representação resolve a problemática da conexão entre categoria e objeto de duas maneiras: primeiro, é uma representação que associa as características da intuição e dos conceitos; segundo, ela assevera que nossos juízos tenham validade objetiva, porque liga as categorias às intuições de forma necessária ou não-empírica. Ricoeur, dessa forma, ao empregar o esquematismo kantiano busca solucionar qual o liame entre a forma lógica do pensamento por similiaridade e o “imaginário” da iconicidade.

Segundo ele, a natureza icônica da semelhança pode ser rearticulada de modo que a imaginação se torne ela própria um momento propriamente semântico do enunciado metafórico. A única possibilidade de se coligar ao problema da imaginação na dimensão de uma teoria semântica é principiar com a imaginação produtiva no sentido kantiano. Como esquema, a imagem oferece uma perspectiva verbal; antes de ser o ponto de junção de percepções aumentadas, é o de sentidos emergentes. Se o esquema é a matriz da categoria, o ícone é a matriz da nova pertinência semântica, que aparece da destruição de redes semânticas causadas pelo choque de contradição. "Ricoeur sugere que o momento icônico envolva um aspecto verbal, que constitua a captação da identidade nas diferenças e apesar das diferenças, mas baseado num padrão pré-conceitual”. (NUNES, [Jordão], 2000, p.128) Assim, a metáfora é instituída como esquematismo no qual a função metafórica é produzida. O esquematismo conduz a imaginação ao lugar onde o sentido figurativo insurge na interação entre identidade e diferença. No discurso, a metáfora é o lugar onde esse esquematismo é visível, porque a identidade e a diferença não se misturam, mas enfrentam uma à outra. Ricoeur atesta que um esquematismo da atribuição forma a questão na fronteira da semântica e da psicologia onde o imaginário é ancorado numa teoria semântica da metáfora ${ }^{66}$.

Sua reflexão, porém, não se restringe ao domínio semântico, de ênfase no sentido. Sob este aspecto, introduz o problema da referência: é a passagem da semântica, em que a sentença é entendida como unidade fundamental, para a hermenêutica, no qual o texto tem um

\footnotetext{
${ }^{66}$ Para uma discussão mais abrangente Cf. o texto de Ricoeur (In: SACKS, 1992, p.145-160) “O processo metafórico como cognição, imaginação e sentimento”.
} 
papel de mediador entre a produção do significado e a sua "correspondência objetiva” no mundo do texto. A metáfora, no campo da referência, tem o poder de projetar e revelar este mundo; tema já explanado no início deste capítulo ${ }^{67}$ e que será retomado no item posterior.

Em suma, é chegado o momento em que algumas observações devem ser feitas deste estudo imódico e especulativo: 1 . o elenco de nomes e as teorias descritas foram escolhidos na medida em que serviram de base para exemplificar que, mais do que um estilo, a metáfora tem um papel cognoscitivo, atuante no processo interpretativo; 2. das múltiplas teorias da metáfora, a proposta por Ricoeur ${ }^{68}$ foi privilegiada por servir de base para a discussão da leitura crítica - leitura hermenêutica, pela qual a crítica de Nunes se ampara; e 3. a amplitude da atividade metafórica, apenas esboçada neste espaço, mostra que o exame da metáfora abre uma perspectiva relevante para o questionar da linguagem, ou melhor, da construção da linguagem.

\section{2. A construção da linguagem crítica}

Estabelecidas, pois, as bases para que a metáfora fosse vislumbrada no seu poder de natureza multidisciplinar, epistemológica e, principalmente, de "apreensão da realidade”69, cabe, agora, retomar algumas questões que ficaram esparsas ao longo desse excurso: de que forma a crítica literária de Benedito Nunes parte da metáfora para iniciar um processo interpretativo? Qual a relevância desse aspecto?

De saída, é preciso lembrar que, como já apontado no primeiro capítulo ${ }^{70}$, Nunes acompanha bem de perto as reflexões desenvolvidas por Ricoeur a respeito da interpretação. Com efeito, como intérprete hermenêutico, seu ato de leitura corrobora as posições ricoeurianas acerca desse tema, em que a metáfora, por sua vez, comparece como articulada ao restante do seu projeto.

\footnotetext{
${ }^{67}$ Cf. p.182-3 e item I.4.1, p.88-91. Ricoeur dedica o cap. VII (Métaphore et référence), de La métaphore vive (1975, p.273-321) a esta questão.

${ }^{68}$ Sabe-se que dificilmente uma teoria oferece plenas condições de abarcar as peculiaridades de um texto. No caso de um discurso crítico, essa dificuldade é maior. Nunes (1986) refere-se particularmente a Ricoeur quando do debate a respeito do trabalho da interpretação. Dessa forma, ao restringir essa discussão ao seu arcabouço teórico, procurei apenas abrir uma possibilidade de leitura da crítica nuneana.

69 "De fato, das duas uma: ou se admite a vinculação entre a formação das metáforas e o esforço humano de apreensão da realidade (não importa que seja através do uso de uma máscara), ou se vê a metáfora como elemento desligado de um sistema mais amplo, e apenas integrando um repertório de tropos esvaziado de significações relacionais”. (BARBOSA, 1974, p.16)

${ }^{70}$ Cf. item I.4.2.(Hermenêutica e crítica literária: o intérprete Benedito Nunes), p.92-99.
} 
Ricoeur apresenta não só um sentido metafórico, mas uma referência metafórica; isto é, mostra o poder do enunciado metafórico de redescrever uma realidade inacessível à descrição direta; em fazer do "ver como", em que se resume o domínio da metáfora, o revelador de um "ser como” ontológico. A metáfora intenta dizer aquilo que é; por isso a tensão entre a verdade metafórica e a "literal”:

\begin{abstract}
Le paradoxe consiste en ceci qu'il n'est pas d'autre façon de rendre justice à la notion de vérité métaphorique que d'inclure la pointe critique du "n'est pas» (littéralement) dans la véhémence ontologique du « est » (métaphoriquement). (...) C'est cette constitution tensionnelle du verbe être qui reçoit sa marque grammaticale dans « l'être-comme » de la métaphore développée en comparaison, en même temps qu'est marquée la tension entre le même et l'autre dans la copule relationnelle. (RICOEUR, 1975, p.321 - grifo do autor)
\end{abstract}

Para Ricoeur, a interpretação literária é semelhante à da metáfora, já que concorda com Beardsley de que uma metáfora é um “poema em miniatura” (In: RICOEUR, 2000, p.58) e a explicação de uma metáfora é um modelo de toda explicação. O que une tal explicação da metáfora à de uma obra literária é a construção do significado do texto, pois o edificamos de modo similar a como erigimos o sentido de todos os termos de um enunciado metafórico.

Entre o texto e o leitor há uma relação assimétrica: a leitura é associada à execução de uma peça musical, em que a interpretação é limitada pelas regras e notações da partitura. Tanto o texto quanto a peça musical são independentes em relação às intenções do autor. (Cf. RICOEUR, 2000, p.87)

Sabe-se que Ricoeur reformulou a relação entre explicação e compreensão, que, no Romantismo, era concebida como uma dicotomia entre dois campos epistemológicos distintos. A este dualismo metodológico da explicação e da compreensão, Ricoeur propõe uma metodologia dialética:

Par dialectique, j’entends la considération selon laquelle expliquer et comprendre ne constitueraient pas les pôles d'un rapport d'exclusion, mais les moments relatifs d'un processus complexe qu'on peut appeler interprétation. (RICOEUR, 1986, p.180)

A explicação não elimina a compreensão; antes, é mediação imprescindível demandada pela própria falibilidade do discurso humano. Dessa forma, a compreensão passa pela explicação. Por outro lado, a explicação obtém seu êxito pela compreensão. É o empenho de compreensão que pode reviver o texto, conduzi-lo à condição de texto vivo, com capacidade de comunicação atual. Não se trata de psicologismo, de querer procurar a intenção 
do outro escondida no texto. Trata-se, pois, de buscar o mundo que o texto cria, aponta, sugere para o leitor.

A interpretação não procura algo que está “por trás” do texto, mas se apropria das proposições de mundo abertas pelas referências não-ostensivas do texto. Compreender, assim, é trilhar a dinâmica da obra, o movimento de seu sentido à sua referência; deixar que o texto se abra e se revele a nós. É desse modo que Ricoeur entende a "fusão de horizontes" gadameriana $^{71}$ e se apóia na noção de Verstehen (compreender) de Heidegger, compartilhada também por Nunes:

Se não podemos definir a hermenêutica pela procura de um outro e suas intenções psicológicas que se dissimulam por detrás do texto, e se não pretendemos reduzir a interpretação à desmontagem das estruturas, o que permanece para ser interpretado? Resposta: interpretar é explicar o tipo de ser-do-mundo manifestado diante do texto. (NUNES, 1999, p.148)

A leitura hermenêutica empreendida por Benedito Nunes, portanto, busca no mundo do texto também o "ser como” metafórico, que é a abertura, a forma com que examina o modus operandi, o “como” de uma obra literária.

É a maneira como realiza tal empenho que interessa pôr em cena neste momento, a fim de ilustrar a construção da sua crítica.

Por certo, não há a preocupação de se estabelecer um roteiro de análise, como se as interpretações de Nunes seguissem fórmulas ou regras. O que se acentua é uma possibilidade de mostrar e/ou demonstrar suas leituras, ou melhor, as diferentes leituras que, ora privilegiam o aspecto sonoro, ora o morfo-sintático, ora o semântico-lexical, e põem em destaque, por vezes, o elemento metafórico.

O eventual caráter imagético da sua linguagem aparece consubstanciado, é importante ressaltar, a uma reflexão que privilegia investigar, na obra literária, problemas que são impasses do e para o pensamento e que se vinculam às linhas do pensamento históricofilosófico. Eis um exemplo escolhido aleatoriamente:

- “A resposta que o flâneur escoliasta, colecionador de signos, hermeneuta à busca do sentido, sem parecer estar nisso empenhado, dá à fugacidade e à incerta identidade da obra, é a interpretação aproximativa e problemática desse método, que terá utilizado já como tradutor dos mesmos poemas de Safo”. (NUNES, 2003, p.13)

\footnotetext{
${ }^{71}$ Cf. item I.4.1. (Breves interfaces do pensamento hermenêutico), p.82.
} 
Este trecho pertence ao texto de apresentação da obra Eros, tecelão de mitos - $a$ poesia de Safo de Lesbos, de Joaquim Brasil Fontes ${ }^{72}$, denominado “Que isto de método...”. Nunes enaltece a "singular e ousada abordagem” (p.11) do ensaio e, ao mesmo tempo em que tece considerações à tradução do poema de Safo composta por Fontes, cria uma linguagem de epítetos ("flâneur escoliasta”; “colecionador de signos”), de forte sonoridade ("Esse flâneur, novo escoliasta, recolhe, curioso e moroso...[p.12]), e evidencia a questão da interpretação e da tradução:

- “A compreensão possível, que precede e orienta toda interpretação, depende, em última análise, da condição temporal do pensamento e da historicidade de nossas relações com o mundo”. (p.14)

- "Em resumo, é do intraduzível que vem a resistência que o idioma estrangeiro - a sua estranheza - oferece ao tradutor, e é contra o intraduzível que o tradutor se debate. Seguido de perto por Walter Benjamin, nesse admirável ensaio que é A Tarefa do tradutor, Goethe aconselhava que o intraduzível fosse a meta e a medida do trabalho de tradução...”. (p.15)

Sua leitura, dessa forma, no embate com as tensões do texto estudado, cria um tecido crítico em que há um equilíbrio entre a criação de uma linguagem ocasionalmente metafórica e as reflexões suscitadas pelo assunto da obra.

Há, por outro lado, análises que privilegiam um aspecto da linguagem, por exemplo, o sonoro. Para tal caso, pode-se selecionar a crítica de Benedito Nunes de “O ‘fragmento’ da juventude”,73, a respeito do poema de Mário Faustino. Crítica esta considerada, por Leyla Perrone-Moisés (2000, p.313-4), uma "leitura feliz":

Benedito Nunes, leitor de Mário Faustino, está, a meu ver, na categoria hors
concours. Um fino crítico como Benedito Nunes, lendo um poema belíssimo como
"Juventude", de Mário Faustino, é algo que coloca a poesia e a crítica brasileiras no
seu mais alto patamar. O crítico se desincumbe da difícil tarefa de mostrar a
particularidade de um poema cujo tema não poderia ser mais geral: amor e morte,
tempo e eternidade. Ao mesmo tempo que usa, discretamente, seu vasto arsenal
filosófico, ele procede a uma leitura musical do poema, ressaltando sua
"avassaladora sonoridade”, seu "efeito encantatório" por iteração, paronomásia e
ritmo ondulatório. O poema de Mário Faustino se revela, assim, como próximo da

${ }^{72}$ Cf. FONTES, Joaquim Brasil. Eros, tecelão de mitos - a poesia de Safo de Lesbos. São Paulo: Iluminuras, 2003. Este livro é originalmente tese de livre docência, defendida na UNICAMP em 1989, da qual Benedito Nunes foi um dos argüidores da banca.

${ }^{73}$ Cf. NUNES, Benedito. O "fragmento" da juventude. In: Bosi, Alfredo (org.). Leitura de poesia. São Paulo: Ática, 2001, p.175-190. 
essência da poesia lírica: “ação celebratória”, ou, no conceito de Valéry, desenvolvimento de uma exclamação em face da maravilha de haver mundo e vida.

Em um primeiro momento, após situar rapidamente o leitor acerca da escrita dos “Fragmentos” de Faustino, Nunes deixa claro qual será o seu método de análise:

\begin{abstract}
Ao neutralizar a intenção psicológica desse projeto biográfico-artístico, em proveito da intencionalidade de JUVENTUDE, aqui analisado, numa leitura de compreensão, do ângulo de uma fenomenologia do poema, em busca de seu sentido, essa composição perde a excepcionalidade conferida à série, sem perder o caráter de "fragmento", que deve à sua forma peculiar de "pequeno poema lírico”, e religa-se, juntamente com as suas congêneres, ao conjunto da obra realizada pelo poeta, de que todas são efetivamente partes, ao lado das poesias de O homem e sua hora (1955) e dos textos experimentais (1956-1959) que as antecederam. (grifo do autor) (NUNES, 2001, p.176)
\end{abstract}

O crítico se pergunta, dessa forma, como buscar o sentido do poema de grande sonoridade, com os temas freqüentes da lírica de Faustino - amor e morte, tempo e eternidade - e em que as palavras “maravilha” e “vento” são diversas vezes reiteradas?

A resposta é encontrada no ritmo, nomeado de “ondulatório” (até por causa da forma do "fragmento"), no "efeito encantatório" de um ritmo “cantabile”, que procura o "dizer oblíquo” do poema. Tal “dizer oblíquo” é explicado em nota à parte: “além da escolha, do lugar e do encantamento das palavras, é pois, sobretudo, a totalidade da configuração rítmica do dizer poético que 'exprime’ o que se chama de sentido (Sinn) Heidegger, Hölderlins Hymnen,'Germanie' und 'Der Rheine', Gesamtausgabe, Band 39, Frankfurt am Main, Vittorio Klostermann, 1980, p.14”. (NUNES, 2001, p.189)

Como o ritmo é "significativo, tanto do ponto de vista semântico quanto sintático" (p.177), é por meio dele, das relações entre o “fonemático e a significação das palavras que o caracteriza”, que a análise se inicia, não sem antes lembrar o uso da noção de ritmo como “fenômeno imanente”. Novamente, aqui, há uma nota elucidativa: “na conceituação de Roman Ingarden, o ritmo é imanente quando prescrito 'por determinado conjunto fonemáticosignificativo’. A obra de arte literária, Lisboa, Fundação Calouste Gulbenkian, 1965, p.67”. (p.188)

Ao estabelecer, pois, como horizonte crítico o sentido expresso pelo ritmo, faz um levantamento, até minucioso, de elementos que ajudam na construção deste, como a pontuação (uso dos travessões), as profusões de rimas internas e de aliterações, o timbre das palavras “vento” e “maravilha” como refrões, a proliferação de paronomásias e o chamado 
“espaço metafórico”, já que não há propriamente “metáforas tópicas” no "Fragmento”, “abundantes nos poemas anteriores de Mário Faustino”. (p.182)

O que ele ressalta como "espaço metafórico", como "espaço metafórico da ação celebratória”, são “versos sentenciosos” que se “sobrepõem à imagem da maré ao estado juvenil” e mostram o elemento fonemático-significativo: a imagem do mar (anagramado em “maravilha” e “amar”); imagem “obsessiva que passa das composições de O homem e sua hora às peças experimentais e aos “fragmentos””. (p.183)

Ao conceder prioridade à camada rítmico-sonora, Nunes seleciona um idioma crítico peculiar à questão musical, que se repete ao longo da investigação, como "variações melódicas”, “andamento”, “intermezzo”, “curva melódica”, “adagio”, “largo maestoso” etc.

Tal como no poema, a crítica de Nunes também abusa dos travessões e cria jogos de palavras, espécie de iteração, presença constante no "Fragmento":

- "Os travessões pontuam unindo o que separam e separando o que unem" (p.179)

- “É recitativo por ser canto, e é canto pela configuração rítmica....” (p.180)

No ritmo “ondulatório", como o ritmo do mar - a imagem metafórica -, a construção analítica também segue um curso, ora para acentuar as entoações, ora para estabelecer o símile de juventude com os “fluxos” e “refluxos” da vida e da morte:

\begin{abstract}
E assim a ação celebratória, que une as duas inflexões, a exultante do elogio e a lamentosa da elegia, num só louvor à juventude e ao sentimento de viver, equivale a um sim dado à vida contraditória e efêmera. Nessa afirmação trágica está o sentido intencional do "fragmento" - o seu dizer oblíquo -, explicitado do ritmo cantante em que se articulou, aceitando e consagrando o amor fati que impregna, desde o começo, a lírica de Mário Faustino. (p.188)
\end{abstract}

Destacam-se, ainda, as notas de rodapé (17 ao todo), que possuem exemplos de outros poemas de Faustino, ou esclarecem a questão teórica (como no caso citado de Heidegger e Ingarden). Como explicações à parte, possibilitam dar à investigação um tom mais leve, mais “ondulante”.

Em síntese, Benedito Nunes elege o “ritmo ondulatório” como a metáfora que percorre cada ponto de sua linguagem crítica, a demarcar que de uma imagem pode-se vislumbrar um sentido de análise. 
Da mesma forma, cria a metáfora "escrita de implantação” para explicar Coivara da memória, de Francisco J. C. Dantas. ${ }^{74}$ Em breve resenha, é nesta imagem que Nunes melhor traduz a importância do livro:

(...) implantação é, enquanto metáfora, a palavra que melhor exprime a fusão, através de uma só perspectiva romanesca, dos dois solos em que assenta Coivara da Memória: o solo como chão regional, como terra, suporte do patriarcalismo rural, do Nordeste, a que se liga pela lembrança o personagem-narrador, e o solo literário, de afloramento das muitas tradições ficcionais - do regionalismo ao mítico supraregionalismo de Grande Sertão: Veredas - microscopicamente incrustadas na matéria e na forma deste belo romance de Francisco José Costa Dantas.

É também no construir metafórico que procura esclarecer que "a poesia sempre diz de novo sem nunca enredar-se nas aporias que tolhem o pensamento filosófico”, pois, para ele, “o texto poético é sempre poroso”. “Poroso”, aqui, é usado como uma adjetivação do substantivo Poros, o nome da obra de Rubens Rodrigues Torres Filho ${ }^{75}$, que Nunes (1989) comenta de forma refigurada: "Poros são diminutos lugares de passagem do vivido ao dito e do dito ao indizível”.

Refiguração, convém lembrar, tal como Ricoeur (1983, p.86) designa: o ponto de encontro entre o mundo do texto e o mundo do leitor, pois é a ação de leitura de Nunes que completa e revela o universo da obra. É o seu ato de ler que desvela a referência, e não o sentido do texto; referência esta em que repousa a metáfora. Em outras palavras: “ce sera précisément la tâche de la lecture, en tant qu'interprétation, d'effectuer la référence". (RICOEUR, 1986, p.157)

Mais do que criar metáforas, nelas se busca - como figuras do discurso - uma realidade nova enunciada pela linguagem. Veja-se este exemplo a respeito do livro - de narrativas curtas - Vôo de Galinha, de Haroldo Maranhão ${ }^{76}$ :

(...) Não é por acaso que a mesma palavra, carambola, que nomeia o fruto redondo da caramboleira (Averrhoa carambola) - fruto de gomos salientes e de muito sumo significa igualmente ardil, tramóia, intriga, ou seja, a trama da fiç̧ão atuando sob a película túrgida da linguagem comprimida. A prosa microscópica é, antes, na verdade, uma microscopia da prosa, isto é, uma experiência bem sucedida de redução do conto ao mecanismo essencial de seu funcionamento. (NUNES, 1982, p.66)

\footnotetext{
${ }^{74}$ Cf. DANTAS, Francisco J. C. Coivara da memória. São Paulo: Estação Liberdade, 1996.

${ }^{75}$ Cf. TORRES FILHO, Rubens Rodrigues. Poros. São Paulo: Duas Cidades, 1989.

${ }^{76}$ Cf. MARANHÃO, Haroldo. Vôo de galinha - peças de um minuto ou dois, ou nem isso. Quase todas no formato de carambolas. Contos redondos. Belém: Editora Grafisa, 1978.
} 
É a partir das metáforas que compõem a obra - pequenas narrativas que são “comparadas ironicamente pelo próprio Autor ao curto e rasteiro voo dos galináceos” (p.65), que o comentário de Nunes se desdobra para tentar alcançar as tensões do enunciado metafórico; tensões estas que, segundo Ricoeur (1975, p.378) ocorrem em "trois niveaux différents de l'énonciation métaphorique: tension entre les termes de l'énoncé, tension entre interprétation littérale et interprétation métaphorique, tension dans la référence entre est et n’est pas”.

De cada breve prosa, o crítico paraense aponta como elas tendem para a “representação exemplar, genérica, de uma situação humana” - ao que ele compara com o miniconto de Cortázar, “Amor - 77”, descrito, na esteira da metáfora usada por Maranhão, como uma “carambola de quatro linhas impressas, francamente alegórica”. (p.66)

Do impulso suscitado pelo caráter "vivo da metáfora”77, redescreve a possível leitura dos minicontos:

Construídas em espaços densificados, que circunscrevem ambientes, objectos, coisas
e pessoas, por meio de cortes temporais regulares pela proximidade ou pelo
distanciamento do narrador ao que vê, descreve ou testemunha, a perspectiva de
humor em que geralmente se enquadram - ajustada a vários modos de concepção ou
sensibilidade - do cômico ao fantástico, do macabro ao grotesco - confere-lhes a
essencial concretude da história, do caso simples ou extraordinário, que recupera,
graças às tretas e tintas da escrita, o prazer de narrar: o gosto forte de uma carambola
de prosa impregnando o leitor. (NUNES, 1982, p.66)

Esse trecho, além de recuperar um aspecto já apontado no início do capítulo ${ }^{78}$, o adiamento do ponto final, que acentua um caráter oral, revela como Nunes retoma a metáfora do texto-objeto para construir a sua linguagem, em uma dinâmica de leitura que busca, no mundo do texto, as projeções do próprio intérprete, pois ler é, em qualquer hipótese,

enchaîner un discours nouveau au discours du texte. Cet enchaînement d'un discours à un discours dénonce, dans la constitution même du texte, une capacité originelle de reprise qui est son caractère ouvert. L'interprétation est l'aboutissement concret de cet enchaînement et de cette reprise. (RICOEUR, 1986, p.170)

\footnotetext{
77 'La métaphore est vive en ce qu'elle inscrit l'élan de l'imagination dans un 'penser plus' au niveau du concept. C'est cette lutte pour le 'penser plus', sous la conduite du 'principe vivifiant' qui est l' 'âme' de l'interprétation". (RICOEUR, 1975, p.384)

${ }^{78}$ Cf. p.179.
} 
Ler também implica reavivar o repertório de leituras, outras tantas associações, que se misturam e compõem, no discurso crítico de Nunes, comparações pontuais que alargam a perspectiva de análise.

É assim que percebemos obras mais recentes concebidas como próximas às características de Dom Quixote, ou às narrativas de Guimarães Rosa:

A cavalgada é, por um lado, quixotesca - não fosse o zaino Brioso da estirpe de Rocinante - e, por outro, apesar de seu trágico arremate, burlesca, quando o tio, em seus rompantes, estripulias e caprichos, se torna roseanamente aparentado de “Tarantão, meu patrão”, de Primeiras estórias. (NUNES, 2000, s/p)

Esta pequena passagem é o comentário que Benedito Nunes tece a respeito do livro Meu tio Roseno, a cavalo, de Wilson Bueno ${ }^{79}$. Tal qual a narrativa, no ir e vir da cavalgada, o discurso crítico ressalta ora o ritmo da história, ora sua linguagem, para, por fim, nomeá-la, por duas vezes, de “ficção sagaz” e de fronteiriça:

Híbrido fecundo, a ficção sagaz é um gênero de fronteira - passa de lugar a lugar como de língua a língua, no limite entre a lembrança retrospectiva e a percepção comum, reelaborados pela força da linguagem. Meu tio Roseno, a cavalo é também fronteiriça porque une e separa a história do tio e do sobrinho narrador. (NUNES, 2000, s/p)

A lembrança de Guimarães Rosa é presente em outras críticas, como a de Coivara da memória, de Francisco J. C. Dantas, já citada, basicamente quando há a intenção de enaltecer o trabalho com a linguagem, como no caso de Dalcídio Jurandir:

Herdeira dos nossos ficcionistas do século XIX, como Inglês de Sousa e José Veríssimo, cujo naturalismo depurou, essa escrita de um inventor e Mestre, mais próxima, no uso do idioma, do supra-regionalismo de Guimarães Rosa.... (NUNES, 2006, p.11)

Aliás, a importância da prosa do escritor marajoara ${ }^{80}$, sobre a qual foge aos limites deste trabalho explanar, é comparada por Nunes a outras obras, cuja linguagem é tecida pelo tempo e pela memória:

Tal como acontece em O tempo e o vento, de Érico Veríssimo, Os Buddenbrooks, ou José e seus irmãos, de Thomas Mann, ou, ainda, em Os sonâmbulos, de Hermann Broch, o romance de Dalcídio, com paisagens, personagens e situações comuns, desdobra-se em romances. Em todos eles encontramos uma história dividida em histórias de diversificada narrativa, mas de forma circular, porque sempre voltando aos mesmos pontos, em longo percurso temporal, que pode depender da memória de

\footnotetext{
${ }^{79}$ Cf. BUENO, Wilson. Meu tio Roseno, a cavalo. São Paulo: Editora 34, 2000.

${ }^{80}$ A respeito de Dalcídio Jurandir Cf. JURANDIR, Dalcídio. Romancista da Amazônia - Literatura \& memória. Organização de Benedito Nunes, Ruy Pereira e Soraia Reolon Pereira. Belém: SECULT; Rio de Janeiro: Fundação Casa de Rui Barbosa/Instituto Dalcídio Jurandir, 2006.
} 
quem narra, lembrança após lembrança, parte após parte, tomo após tomo, como em À la recherche du temps perdu, de Marcel Proust. Tal como nesta, a memória do narrador, remergulhando na sua infância e na sua juventude, abastece o ciclo do nosso romancista. (NUNES, 2006, p.246)

Se "o memorialismo do romance de Dalcídio entra numa galeria de espelhos, com múltiplos reflexos internos” (p.251), o memorialismo do crítico se desdobra em inúmeras vertentes, sempre pronto a sublinhar outras referências. É dessa forma que a memória da narrativa se articula com a lembrança de seu repertório de leitura: "Esse traço proustiano se adensa com um toque forte, à maneira de Dostoiévsky, da mimese de rebaixamento, de que fala Northop Frye...”. (p.247)

De igual modo, aprofunda o tema da morte em Drummond ${ }^{81}$ ao citar os poetas Tristan Corbière e Jules Laforgue, que "consideraram o aspecto puramente humano da morte, a aparência negativa que ela comporta, quando esvaziada de seu fundo místico e escatológico”. (NUNES, 2002/2003, p.20)

O interessante deste ensaio é que Nunes o inicia para enunciar a constante temática da morte na poesia de Drummond, que se contrapõe “ao vazio e à banalidade da vida cotidiana”. Porém, a morte também aparecerá como “matéria de experiência. Sustentada pela duração real, a convivência com os mortos (...) excede ao saudosismo da escavação do passado, à busca de lembranças consoladoras”. (p.18) Mais adiante, encerra uma primeira parte:

\begin{abstract}
Mediada pelo convívio com os mortos, e sempre contrabalançada pela atitude de resistência ética, que se fixa na vida e nada espera além dela, a experiência da morte, na poesia de Carlos Drummond, a partir de A Rosa do Povo, assimilará reflexivamente, através da experiência decepcionante do tempo e do amor, o próprio desejo de aniquilamento. (p.19)
\end{abstract}

Ao interromper a análise de Drummond, passa a explicar a experiência da morte em Fernando Pessoa, cujo tema aparece

quase sempre associado ao do conhecimento, é absorvido numa indagação patética do sentido do ser, a extensão e a profundidade de uma busca metafísica, paralela ao espírito de seriedade especulativa que marcou o rumo das preocupações intelectuais desse poeta. (p.19-20)

Em seguida, comenta acerca de Tristan Corbière e Jules Laforgue e encadeia suas observações com um esclarecimento a respeito do ceptismo de Montaigne:

\footnotetext{
${ }^{81}$ Cf. NUNES, Benedito. Carlos Drummond: a morte absoluta. In: Carlos Drummond de Andrade - 100 anos. Revista da Biblioteca Mário de Andrade. São Paulo, v.60/61, jan./dez.2002/2003, p.18-29.
} 
O ceptismo não é refratário a uma certa nostalgia, de que nem mesmo um Montaigne esteve isento. Ao parafrasear, no seu ensaio Que Philosopher c'est apprendre à mourir, o ensinamento de Platão - filosofar é aprender a morrer - Montaigne esvaziou-o da crença na imortalidade da alma, rigorosa e firme para o autor dos Diálogos, convertendo-o num outro ensinamento, verdadeiro paradoxo afinal, de que tanto é melhor a morte quanto mais morrida for. Era uma maneira de dizer-nos que o único benefício real daquela aprendizagem está na experiência de aceitação, a que se pode chegar em vida, do completo aniquilamento na morte. (p.21)

Antes de seguir para uma terceira etapa da análise, a penúltima, Nunes deixa clara a idéia principal que defenderá ao longo da investigação:

Carlos Drummond, "poeta do finito e da matéria”, que a esse respeito passou por uma aprendizagem que se poderia qualificar de montaigniana, dar-nos-á, como veremos a seguir, lição semelhante, que o distancia de Fernando Pessoa e o aproxima de Tristan Corbière e Jules Laforgue. (p.21)

Percebe-se, deste modo, que as citações de poetas e filósofos se mesclam, se completam e qualificam o discurso crítico de um hermeneuta que tem consciência de que “interpréter c'est prendre le chemin de pensée ouvert par le texte, se mettre en route vers l'orient du texte”. (RICOEUR, 1986, p.175 - grifo do autor)

O diálogo entre textos é, pois, resultado das memórias de leituras; leituras de textos que

\begin{abstract}
fecundam nossa experiência [e] são aqueles dos quais nos aproximamos livremente, animados pelo "prazer de um honesto passatempo" (par un honête amusement), do qual falou Montaigne, ou que parecem vir ao nosso encontro, a chamado de uma afinidade, de uma idéia, de um sentimento. Tanto os clássicos da Literatura quanto os da Filosofia precisam da escolha eletiva do leitor para que prosperem, servindolhe, segundo a função atribuída a eles por Italo Calvino, de "equivalente do universo, à semelhança dos antigos talismãs”. (NUNES, 1998, p.177)
\end{abstract}

Um dos textos que veio ao seu encontro, uma das suas afinidades, é com a obra e o pensamento de Martin Heidegger. Assim, não poderia haver outro crítico que melhor pudesse comentar Sabedoria do nunca, de Juliano Garcia Pessanha ${ }^{82}$.

Tal livro, na verdade, traz um tema caro para Nunes: a intercomunicação entre a linguagem da literatura e a da filosofia. Dividido em três partes, que se complementam ficção, poema e ensaio -, esse escrito de Pessanha é o primeiro de uma trilogia (Ignorância do sempre e Certeza do agora $^{83}$ ) e, como revela Heitor Ferraz na contracapa,

\footnotetext{
${ }^{82}$ Cf. PESSANHA, Juliano Garcia. Sabedoria do nunca. Ateliê Editorial Ltda., 1999.

${ }^{83}$ Respectivamente publicados pela Ateliê Editorial Ltda. em 2000 e 2002.
} 
para facilitar, pode-se dizer que este livro é uma árdua e angustiante investigação do ser, do homem que quer pertencer ao mundo convencionado, como recebemos no berço, e não encontra entrada (ou, como ele diz no ensaio, a chave está perdida).

Na apresentação, Benedito Nunes assinala que os três momentos (a ficção, o poema e o ensaio) são “tão argutos quanto sibilinos” e “apagam a diferença entre filosofia e literatura, em cujos frágeis limites se colocam”. (p.13)

Pergunta o crítico se é possível nivelá-los literariamente, mas percebe que

ficção não é gênero literário. Gêneros literários são o conto, a novela e o romance. A palavra "ficção" denomina o estado de distanciamento entre palavra e realidade, que se indicia a si mesmo. Não ostentam poemas e ensaio, cada qual a seu modo, a emplumada asa da ficção que o lança para o não real? (p.13-4)

Após aproximar as imagens à consistência dos sonhos, dos sonhos do "pensamento de Próspero em The Tempest, de Shakespeare” e do “todo da linguagem, entre sonho e vigília”, de Macbeth, salienta que o "valor literário dos escritos (...) exorbitam a literatura, pois que a ficção especula, os poemas a repercutem e o ensaio concretiza uma experiência imaginária”. (p.14)

Neste sentido, vincula o texto às linhas do pensamento histórico-filosófico, da qual a forma representa as principais instâncias de questionamento:

Canto de exilado são os poemas, porque quem os compõe, escreve para conquistar o
tempo que lhe escapa e para recuperar a fala da qual foi destituído. O ensaio mostra
que o si mesmo é uma barreira limitada. A liberdade, de que só se pode ter a
imaginária experiência, alcançada pela ficção, romperia o limite do acontecer na
direção do nada, esta sim, a mais extrema possibilidade. Ela estaria para o si mesmo
como o ontológico está para o ôntico. Esse vocabulário ensaístico permite identificar
a raiz heideggeriana dos temas - o tempo, a finitude, e o Nada - desses três escritos,
independentes mas inseparáveis, partes de um único retábulo da situação humana,
entrevista como um jogo desigual, de cujas peças centrais não dispomos por inteiro.
(p.15)

Sua prática de leitura, no movimento executante de um ato que concretiza a obra, procura no "preenchimento das significações das palavras, dos correlatos objetuais das frases que configuram personagens e delineiam situações no espaço e no tempo, [o] reconhecimento dos valores e da figura de um mundo imaginário”. (NUNES, 1998, p.180)

É um exercício de crítica que fomenta questões e, mais do que respondê-las, tenta compreender o texto para, na experiência de sua leitura, compreender a si mesmo. Pode-se, dessa forma, dizer que a linguagem crítica de Nunes apresenta semelhante textura com a definição que João Alexandre Barbosa (1990) concebe da crítica como releitura: aquela em 
que o crítico não se pauta por tentar decifrar ou explicar o sentido do texto, mas, sim, por expor o objeto literário como uma perspectiva de um questionar do próprio homem e do seu mundo simbólico. O trabalho do crítico-leitor, então, ocorre por aproximações e possibilidades, pelo deixar-se provocar pelo que leu e pelo mergulho nas incertezas da literatura.

Da mesma forma, compartilha também da metáfora crítica criada por Barbosa (1990, p.26): a leitura como intervalo. Isto porque, no conceito de dimensão intervalar da literatura, ressalta-se que

\begin{abstract}
na literatura lê-se sempre mais do que a literatura, embora deva-se dizer bem depressa que só é mais do que literatura porque a intensidade com que se trabalha os valores da linguagem, isto é, o que é próprio da literatura, leva à problematização radical dos demais valores - filosóficos, psicológicos, sociais, históricos veiculados pela literatura.
\end{abstract}

Para a análise do fenômeno literário, portanto, pede-se uma postura interdisciplinar. Interdisciplinaridade esta observada, por exemplo, quando da crítica de Clarice Lispector ${ }^{84}$ e de Guimarães Rosa ${ }^{85}$.

Benedito Nunes, leitor de prosadores, que realça os "limites de extrema tensão, reveladoras de nós mesmos e do outro” (NUNES, 1998, p.184); leitor de poetas que, em resumidas contas, soube ressignificar o exercício crítico, seja pela defesa dos “ideais antropofágicos” oswaldianos, seja por alargar, por meio da análise fenomenológica, os traços da linguagem de João Cabral de Melo Neto ${ }^{86}$, seja por auscultar a palavra "levada a efeito" por Age de Carvalho ${ }^{87}$.

Enfim, ao sublinhar esses aspectos do construir da linguagem crítica de Benedito Nunes tentou-se, ao menos, estabelecer um exercício hermenêutico, tal qual ele, como intérprete entende, no limiar da metáfora do horizonte descrita por, entre outros, Gadamer (2002): projetar, em um primeiro momento, um olhar de busca, ainda que fincado no solo da pré-compreensão, que define limites. Foi assim que se procurou depurar, de sua linguagem, seus principais movimentos de organização.

\footnotetext{
${ }^{84}$ Cf. item I.2.1.(Clarice Lispector), p.36-42.

${ }^{85}$ Cf. item I.4.4.(Guimarães Rosa), p.101-109.

${ }^{86}$ Cf. item I.1.8. (João Cabral de Melo Neto), p.31-32.

${ }^{87}$ Texto a respeito de Age de Carvalho datado de dezembro de 2005.
} 
Em seguida, ao mergulhar na abertura dada pela sua linguagem, buscou-se mostrar seu recurso de diálogo com a obra estudada; a prática dialógica que cria e recria, com base no texto-objeto, sua fonte metafórica de expressão.

Por último, ao deslocar-se para um salto no infinito do próprio horizonte-texto, a intenção foi a de ratificar que a hermenêutica de Benedito Nunes é feita mais de perguntas do que de respostas, na eterna releitura que a crítica promove; crítica esta que estabelece uma conversa com o leitor para, como toda boa conversa, provocar novos olhares; abrir para novas perspectivas, novos horizontes... 
“(...) as indagações finais desse trabalho inconclusivo, propostas a título de pretexto para discussão”.

(Benedito Nunes) 
Considerações Finais 
A leitura que procurei estabelecer com a vasta bibliografia de Benedito Nunes teve como principal enfoque alargar o sentido e a importância de sua produção. Isto é, demonstrar que seus escritos não se restringem à relação literatura e filosofia, mas são designativos de um universo que abrange um repensar sobre a estética, a música, o teatro, a religião etc.

Objetivei, assim, traçar um panorama de sua obra e discutir pontos-chave da sua escritura. Neste sentido, privilegiei destacar suas linhas de pesquisa, evidenciar seu método de trabalho crítico, o modo de construção da sua linguagem e a sua contribuição à história da crítica brasileira.

Diante de tal tarefa, dividi o estudo em três momentos. No primeiro, busquei ressaltar seus principais textos e temas. Não havia uma preocupação específica nem com a ordem cronológica das suas obras nem com a sua biografia. No entanto, ao longo das considerações, seu pensamento crítico, os fatos e as situações de sua vida correram em paralelo. Ao comentálos, sobressaíram-se lampejos da cultura e da história que marcaram Nunes, como a criação do Suplemento Literário da Folha do Norte, ou de outros Suplementos Literários, como o do Estado de S. Paulo, e do Jornal do Brasil.

Ao margear seu percurso crítico, rememorei seus primeiros contatos com a imprensa e a convivência com os "amigos do Norte", como Haroldo Maranhão, Prof. Francisco Paulo Mendes, Mário Faustino, Dalcídio Jurandir, Max Martins, entre outros.

Aliás, foi sobre o livro O estranho, de Max Martins, que Nunes se iniciou na crítica, em 1952, com um artigo intitulado "A estréia de um poeta". As comparações que teceu entre o trabalho poético do poeta paraense e o de Carlos Drummond de Andrade possibilitaram que eu discutisse os pontos da crítica que Nunes realizou tanto de um quanto de outro. De Drummond mostrei sua ponderação acerca do tema da morte e do resultado do humor que, no autor mineiro, apareceu consubstanciado à reflexão.

Dessa relação reflexiva, que aproxima transversalmente a poesia da filosofia, ressaltei a interpretação nuneana a respeito da poética de João Cabral de Melo Neto que, por ser racional e exterior, apresenta pontos em comum com a de Fernando Pessoa, pois ambas reportam-se sempre ao destinatário, ao Outro.

A relação transversal entre poesia e filosofia também permitiu que eu comentasse acerca da analítica de Nunes dos poetas Rainer Maria Rilke e T. S. Eliot. 
Sob este enfoque, meu objetivo era pôr em perspectiva sua leitura crítica dos escritores que ele elegeu como tema de estudo. Para isto, fixei-me nos seus principais ensaios a respeito de cada poeta.

Ainda nessa linha, destaquei que foi em decorrência de seu trabalho na imprensa que se iniciaram suas primeiras publicações em livro: O mundo de Clarice Lispector (1966) e outros dedicados à filosofia: Introdução à filosofia da arte (1966), A filosofia contemporânea (1967) e Farias Brito (1967).

Quando se comenta a fortuna crítica de Clarice Lispector, quase sempre se sobressai o nome de Benedito Nunes. Por isso, dediquei uma maior atenção às inúmeras reflexões produzidas pelo ensaísta paraense acerca dos escritos clariceanos. Ainda que, em um primeiro momento, Nunes tenha estudado sua obra como uma ilustração ao pensamento sartreano, soube, depois, reconhecer que se deve evitar o risco de reduzir o literário a um esquematismo filosófico.

Para ele, a investigação filosófica de uma obra literária compreendida como forma deve ser examinada por meio de três aspectos: a) a linguagem; b) as conexões da obra com as tendências do pensamento histórico-filosófico; e c) as idéias que são problemas do e para o pensamento.

Das suas produções na área de filosofia, procurei mostrar as relações com outros de seus escritos. Assim, da Introdução à filosofia da arte (1966), explanei o texto "Estética e correntes do Modernismo" (1975), que introduz a problemática da antropofagia oswaldiana, mais bem discutida em Oswald Canibal (1979). Por sua vez, os temas desses ensaios são encontrados em "Educação artística e filosofia da arte" (1976) e "O pensamento estético no Brasil" (1978).

Com exceção deste último, que retomei no segundo capítulo, os outros foram ao menos delineados nos aspectos de uma concepção estética que visa ao embate crítico e analítico com a arte.

Da Filosofia contemporânea, cuja última edição foi revista e atualizada em 2004, enfatizei o último capítulo dedicado à Fenomenologia e Hermenêutica de Ricoeur, com acentuado realce a respeito do processo de narrar e da experiência temporal, já discutida em $O$ tempo na narrativa (1988) e nos textos "Experiências do tempo" (1992) e "O tempo dividido; Cosmos e História" (1993). 
Após um breve comentário sobre o livro Farias Brito (1967), os laços da literatura e da filosofia foram revistos em $O$ dorso do tigre (1969), cuja importância para a crítica brasileira é notória, já que trouxe reflexões pontuais não só acerca da filosofia heideggeriana, mas também da marca do fazer crítico nuneano, movente na prática hemenêutica filosófica e literária, nos estudos de Clarice Lispector, Guimarães Rosa, Fernando Pessoa e João Cabral de Melo Neto.

Com base na filosofia, comentei também dois textos de raízes históricas - "Diretrizes da filosofia no Renascimento" e "O universo filosófico e ideológico do Barroco" -, bem como de investigação da Natureza e da Cultura: "Casa, praça, jardim e quintal" (1994); "A visão romântica" (1995) e "Um conceito de Cultura" (1973), a fim de acentuar que o interesse de Nunes não se limita à crítica literária.

Ao comentar a recepção à sua obra, presente nas dissertações calcadas em um livro seu em particular e nas resenhas críticas dos seus escritos, ressaltei seus prêmios: pelo livro Passagem para o poético: filosofia e poesia em Heidegger (1986), Prêmio Jabuti, em 1987 e Prêmio Multicultural Estadão, em 1998, mesmo ano do lançamento de Crivo de papel, resultado da união de ensaios de Filosofia e Literatura nos moldes de No tempo do niilismo e outros ensaios (1993). Em 1999, recebeu o Prêmio Ministério da Cultura/Funarte publicou Hermenêutica e poesia, que é a reunião de escritos organizados pela professora Maria José Campos, com base nas aulas ministradas por Nunes, de novembro a dezembro de 1994, na Faculdade de Filosofia e Ciências Humanas da Universidade Federal de Minas Gerais.

De cada livro resenhado, busquei extrair suas principais reflexões, discutir suas escolhas textuais e ressaltar o modo como constrói sua crítica.

Tais questões foram privilegiadas ao se examinar seu método de leitura hermenêutica, que apresenta afinidades com a maneira como Ricoeur (2000, p.106) entende o ato de interpretação:

\footnotetext{
(...) a interpretação é o processo pelo qual o desvelamento de novos modos de ser ou, se preferirmos Wittgenstein a Heidegger, de novas formas de vida - proporciona ao sujeito uma nova capacidade de a si mesmo se conhecer. Se a referência do texto é o projecto de um mundo, então, não é o leitor que primeiramente a si mesmo se projecta. O leitor é antes alargado na sua capacidade de autoprojecção, ao receber do próprio texto um novo modo de ser.
}

Para Benedito Nunes, o exercício hermenêutico é realizado quando se procura a "verdade da obra", no dizer de Benjamin (Cf. NUNES, 1993, p.198), impressa como ficção; quando se analisa seu modus operandi, o seu como, revelador dessa verdade. Nesse intento, a 
filosofia e literatura, como linguagens intercambiantes, são os campos em que se movimenta seu discurso crítico.

Como exemplo dessa perspectiva de leitura, comentei sobre os seus principais textos referentes à obra de Guimarães Rosa, estudados sob os mais variados enfoques, como a análise dos elementos épicos e míticos da linguagem, o tema do amor e "motivo da viagem", e o exame das várias possibilidades interpretativas que a leitura da herança literária roseana invoca.

Já no segundo capítulo, selecionei quatro características do seu corpus ensaístico: 1) a crítica definida como tensão entre a escrita dos escritores e a leitura dos críticos; 2) o confronto de idéias estéticas e poéticas; 3) o discurso teórico-crítico marcado por uma postura filosófica; e 4) o procedimento da historicização e o uso constante do ensaio.

Destaquei tais aspectos da mesma forma que o próprio Benedito Nunes faria: uma digressão de cada tema, um cuidado em apresentar as questões tanto no âmbito histórico quanto no filosófico. Em todo caminhar, acompanhei os passos de Nunes para melhor apreender suas ponderações.

Dessa forma, pude afirmar que seu discurso crítico se fundamenta entre o ressaltar do gênero poético, sem que sua própria escritura se transforme em poética, e um modo de pensar a respeito da obra, sem ser uma análise cientificista.

Ao estar consciente dos confrontos estético-poéticos em vigência na História e na crítica literárias, Nunes concebe uma crítica crítico-reflexiva em diálogo com eles. Diálogo este que permite que sua analítica seja uma leitura em ação, um movimento perpétuo, em que vozes de seu repertório filosófico são incorporadas e relidas.

Uma crítica que busca o modo pelo qual a historicidade foi internalizada no texto e que priorizou o fazer textual na forma do ensaio, cuja tensão com o exposto, com a renúncia de pensar pronto, qualifica uma reflexão que não quer se esgotar.

Por fim, centrei-me no modo como ele constrói a sua linguagem crítica. Nesse terceiro momento, tentei assinalar traços do seu processo de escritura. Sua linguagem, assim, foi apresentada como aquela que se equilibra entre a criação de imagens e o revelar das interrogações que são problemas do e para o pensamento.

A metáfora aparece como inscrita, por vezes, na sua crítica. Porém, antes se fez necessário pontuar a natureza multidisciplinar e epistemológica do metafórico. Após esse 
intento, em que se sublinhou a voz de Ricoeur, ao exemplificar a maneira como Nunes tece seus ensaios foi demonstrado que a sua concepção de metáfora se assemelha à do filósofo francês. Isto é, Nunes a entende como a abertura de um "ser como" ontológico, que se mostra no mundo do texto; a possibilidade de se ler, por meio do enunciado metafórico, a redescrição da realidade.

Também neste espaço, foi importante assinalar o quanto sua crítica apresenta afinidades com as reflexões de João Alexandre Barbosa. Em pelo menos dois aspectos essa aproximação procede: na concepção de crítica como releitura e da leitura como intervalo.

Tais noções resumem seu exercício crítico como um questionar constante do objeto de estudo em movimento especular: o crítico-leitor, ao compreender o texto, compreende-se a si próprio e deixa-se provocar pelo que leu e pelas incertezas da literatura.

Claro está que este trabalho privilegiou certo Benedito Nunes; aquele com o qual estabeleci uma interlocução. E não poderia ser diferente. Há, ainda, muito que se dizer acerca de um autor que começou a escrever muito cedo e bebeu em fontes de livros tão diversos; a quem o ofício de ensinar o levou a conhecer outras paragens, outras culturas e tradições.

Mesmo longe de se esgotar, esta pesquisa revelou a importância e o significado da obra e do pensamento de Benedito Nunes, ainda que, é preciso frisar, foi só um primeiro passo... 
Referências Bibliográficas 


\section{$\underline{\text { De Benedito Nunes }}^{88}$}

$\underline{\text { Livros }}$

NUNES, Benedito. O mundo de Clarice Lispector. Manaus: Ed. Governo do Estado do Amazonas, 1966.

. Introdução à filosofia da arte. São Paulo: DESA, 1967. (Coleção Buriti, vol. 7.)

A filosofia contemporânea: trajetos iniciais. Rio de Janeiro: Ao Livro Técnico, 1967. (Coleção Buriti, 18.)

. Farias Brito - trechos escolhidos. Rio de Janeiro: Agir, 1967. (Coleção

Nossos Clássicos, vol. 92.)

. O dorso do tigre. São Paulo: Perspectiva, 1969. (Coleção debates)

. L’Anthropophagisme: Un Aspect du Modernisme Brésilien. Paris, 1969.

. João Cabral de Melo Neto. Rio de Janeiro: Vozes, 1971. (Coleção Poetas

Modernos do Brasil, vol. 1.)

. Leitura de Clarice Lispector. São Paulo: Quiron, 1973. (Coleção escritores de hoje)

. João Cabral de Melo Neto. $2^{\mathrm{a}}$ ed. Rio de Janeiro: Vozes, 1974. (Coleção Poetas Modernos do Brasil, vol. 1.)

. O dorso do tigre. $2^{\mathrm{a}}$ ed. São Paulo: Perspectiva, 1976. (Coleção debates)

. Oswald Canibal. São Paulo: Perspectiva, 1979. (Elos, 26)

. Passagem para o poético - filosofia e poesia em Heidegger. São Paulo:

Ática, 1986. (Ensaios, 122)

. O tempo na narrativa. São Paulo: Ática, 1988.

.O drama da linguagem: uma leitura de Clarice Lispector. São Paulo: Ática, 1989.

Introdução à filosofia da arte. $2^{\mathrm{a}}$ ed. São Paulo: Ática, 1989. (Série Fundamentos, 38).

\footnotetext{
${ }^{88}$ Cronologicamente, pela ordem de publicação.
} 
A filosofia contemporânea: trajetos iniciais. 2a ed. São Paulo: Ática, 1990. (Série Fundamentos, 79.)

A filosofia contemporânea: trajetos iniciais. $3^{\mathrm{a}}$ ed., rev. ampl. São Paulo: Ática, 1991. (Série Fundamentos, 79.)

. Introdução à filosofia da arte. $3^{\mathrm{a}}$ ed. São Paulo: Ática, 1991.

Passagem para o poético - filosofia e poesia em Heidegger. $2^{\mathrm{a}}$ ed. São

Paulo: Ática, 1992. (Ensaios, 122)

No tempo do niilismo e outros ensaios. São Paulo: Ática, 1993. (Série

Temas, 35)

. O tempo na narrativa. $2^{\mathrm{a}}$ ed. São Paulo: Ática, 1995.

. O drama da linguagem: uma leitura de Clarice Lispector. $2^{\text {a }}$ ed. São Paulo: Ática, 1995.

. Crivo de papel. São Paulo: Ática, 1998. (Série temas, v. 67. Filosofia e Literatura)

. Crivo de papel. $2^{\mathrm{a}}$ ed. São Paulo: Ática, 1998. (Série temas, v. 67. Filosofia e Literatura)

. Hermenêutica e poesia - o pensamento poético. Belo Horizonte: Ed. UFMG, 1999.

. Introdução à Filosofia da Arte. 4ª ed. São Paulo: Ática, 1999.

. Crivo de papel. $3^{\mathrm{a}}$ ed. São Paulo: Ática, 1999.

. O Nietzsche de Heidegger. Rio de Janeiro: Pazulin, 2000. (Coleção Ágora)

. Dois ensaios e duas lembranças. Belém: SECULT/UNAMA, 2000.

. (org.) O amigo Chico fazedor de poetas. Belém: SECULT, 2001.

. Heidegger e Ser e Tempo. Rio de Janeiro: Zahar Editora, 2002.

. O tempo na narrativa. $2^{\text {a }}$ ed. São Paulo: Ática, 2003.

. Filosofia contemporânea. Edição Revista e Atualizada. Belém, EDUFFA, 2004. 
\& HATOUM, Milton. Crônica de duas cidades: Belém e Manaus. Belém: SECULT, 2006.

\& PERREIRA, Soraya R.R.; PERREIRA, Ruy P. (org.). Dalcídio Jurandir, romancista da amazônia - Literatura \& Memória. Belém: SECULT; Rio de Janeiro: Fundação Casa de Rui Barbosa/Instituto Dalcídio Jurandir, 2006.

\section{$\underline{\text { Artigos em jornais }}$}

NUNES, Benedito. Confissões de um solitário. In: Folha do Norte. Belém, 25 de agosto de 1946, Suplemento Arte e Literatura, p.4.

. O cotidiano e a morte em Ivan Ilitch. In: Folha do Norte. Belém, 22 de janeiro de 1950, Suplemento Arte e Literatura, p.4.

Fernando Pessoa: poeta metafísico. In: Jornal do Brasil, Rio de Janeiro, 9 de janeiro de 1956, Suplemento Dominical.

. O Homem e sua Hora. In: Jornal do Brasil. Rio de Janeiro, 5 de agosto de 1956, Suplemento Dominical, p 10.

. O Homem e sua Hora. In: Jornal do Brasil. Rio de Janeiro, 12 de agosto de 1956, Suplemento Dominical, p.6.

Análise de um poema. In: A Província do Pará. Belém, 19 de agosto de 1956, Rodapé de Crítica.

. Análise de um poema II. In: A Província do Pará. Belém, 19 de agosto de 1956, Rodapé de Crítica, p.9.

Os elementos do verbo. In: A Província do Pará. Belém, $1^{\circ}$ de setembro de 1956, Rodapé de Crítica, p.9.

. A criação das imagens. Introdução a "Four Quartets” II. In: A Província do Pará. Belém, 30 de setembro de 1956, Rodapé de Crítica, p.11-12.

À margem de Blake. In: A Província do Pará. Belém, 9 de setembro de 1956, Rodapé de Crítica, p.9.

A poética de Goethe. In: A Província do Pará. Belém, 16 setembro de 1956, Rodapé de Crítica, p.11. 
Introdução a "Four Quartets". In: A Província do Pará. Belém, 23 setembro de 1956, Rodapé de Crítica, p.11-12.

. Introdução a "Four Quartets” II. In: A Província do Pará. Belém, 30 de setembro de 1956, Rodapé de Crítica, p.11-12.

. Introdução a “Four Quartets” III. In: A Província do Pará. Belém, 07 de outubro de 1956, Rodapé de Crítica, p.11.

A estética do cinema I. In: A Província do Pará. Belém, 14 de outubro de 1956, Rodapé de Crítica, p.9-10.

A estética do cinema II (Conclusão). In: A Província do Pará. Belém, 21 de outubro de 1956, Rodapé de Crítica, p.11-12.

Saint-Exupéry e Nietzsche. In: Jornal do Brasil. Rio de Janeiro, 21 de outubro de 1956, Suplemento Dominical.

A arte de traduzir. In: A Província do Pará. Belém, 28 de outubro de 1956, Rodapé de Crítica, p.11-12.

- Duas reflexões sobre poesia. In: A Província do Pará. Belém, 5 de novembro de 1956, Rodapé de Crítica.

. Notas de estudo I. In: A Província do Pará. Belém, 18 de novembro de 1956, Rodapé de Crítica.

. Notas de estudo II. In: A Província do Pará. Belém, 25 de novembro de 1956, Rodapé de Crítica, p.11-12.

Notas de estudo III. In: A Província do Pará. Belém, 2 de dezembro de 1956, Rodapé de Crítica, p.11-12.

A função da crítica. In: A Província do Pará. Belém, 8 de dezembro de 1956, Rodapé de Crítica, p.1-2.

. Em torno de um poeta. In: A Província do Pará. Belém, 16 de dezembro de 1956, Rodapé de Crítica, p.1-2.

O valor da epopéia. In: A Província do Pará. Belém, 23 de dezembro de 1956, Rodapé de Crítica, p.1-2.

. Do trágico nos “Lusíadas”. In: A Província do Pará. Belém, 30 de dezembro de 1956, Rodapé de Crítica, p.1-2. 
O valor da epopéia. In: Jornal do Brasil. Rio de Janeiro, 13 de janeiro de 1957, Suplemento Dominical, p.1.

. O Cancioneiro de Garcia de Resende I. In: A Província do Pará. Belém, 13 de janeiro de 1957, Rodapé de Crítica, p. 1-2.

. O Cancioneiro de Garcia de Resende II. In: A Província do Pará. Belém, 20 de janeiro de 1957, Rodapé de Crítica, p. 1-2.

Do trágico nos “Lusíadas”. In: Jornal do Brasil. Rio de Janeiro, 27 de janeiro de 1957, Suplemento Dominical, p.3.

. Valores estéticos do cinema I. In: A Província do Pará. Belém, 27 de janeiro de 1957, Rodapé de Crítica, p.1-2.

Valores estéticos do cinema II. In: A Província do Pará. Belém, 3 de fevereiro de 1957, Rodapé de Crítica, p.1-2.

. Valores estéticos do cinema III. In: A Província do Pará. Belém, 10 de fevereiro de 1957, Rodapé de Crítica, p. 1-2.

. Duas reflexões sobre poesia. In: Jornal do Brasil. Rio de Janeiro, 3 de fevereiro de 1957, Suplemento Dominical.

. Primeira notícia sobre Grande Sertão Veredas. In: Jornal do Brasil. Rio de Janeiro, 10 de fevereiro de 1957, Suplemento Dominical.

. Fernando Pessoa - poeta metafísico (Introdução de um ensaio). In: $A$ Província do Pará. Belém, 24 de fevereiro de 1957, Rodapé de Crítica, p.2.

Humanismo de Saint-Exupéry. In: A Província do Pará. Belém, 3 de março de 1957, Rodapé de Crítica, p. 2.

Inventário e Planejamento. In: A Província do Pará. Belém, 10 de março de 1957, Rodapé de Crítica, p. 1-2.

Arte e moral I. In: Jornal do Brasil. Rio de Janeiro, 10 de março de 1957, Suplemento Dominical.

Arte e moral II. In: Jornal do Brasil. Rio de Janeiro, 24 de março de 1957, Suplemento Dominical, p.02.

Arte e moral III. In: Jornal do Brasil. Rio de Janeiro, 24 de março de 1957, Suplemento Dominical. 
Arte e moral I. In: A Província do Pará. Belém, 17 de março de 1957, Rodapé de Crítica, p.01.

. Arte e Moral II. In: A Província do Pará. Belém, 24 de março de 1957, Rodapé de Crítica, p. 2.

. Caeiro, o guardador de rebanhos. In: A Província do Pará. Belém, 31 de março de 1957, Rodapé de Crítica, p.1.

. Do fenômeno poético I. In: A Província do Pará. Belém, 14 de abril de 1957, Rodapé de Crítica, p. 1.

. Do fenômeno ao poético II. In: A Província do Pará. Belém, 28 de abril de 1957, Rodapé de Crítica, p. 1.

. Notas sobre o Cancioneiro de Garcia Resende. In: Jornal do Brasil. Rio de Janeiro, 21 de abril de 1957, Suplemento Dominical.

. O moderno Edgar Allan Poe I. In: A Província do Pará. Belém, 5 de maio de 1957, Rodapé de Crítica, p. 1.

. O moderno Edgar Allan Poe II. In: A Província do Pará. Belém, 12 de maio de 1957, Rodapé de Crítica, p. 1.

. O moderno Edgar Allan Poe III. In: A Província do Pará. Belém, 19 de maio de 1957, Rodapé de Crítica.

. O moderno Edgar Allan Poe IV. In: A Província do Pará. Belém, 26 de maio de 1957, Rodapé de Crítica, p. 1.

. O moderno Edgar Allan Poe V. In: A Província do Pará. Belém, 2 de junho de 1957, Rodapé de Crítica, p. 1.

. O moderno Edgar Allan Poe I. In: Jornal do Brasil. Rio de Janeiro, 2 de junho de 1957, Suplemento Dominical.

. As flores do mal. In: A Província do Pará. Belém, 7 de junho de 1957, Rodapé de Crítica.

. O moderno Edgar Allan Poe II. In: Jornal do Brasil. Rio de Janeiro, 9 de junho de 1957, Suplemento Dominical.

. O pensamento de Sócrates. In: A Província do Pará. Belém, 9 de junho de 1957, Rodapé de Crítica. 
. O pensamento de Sócrates I. In: Jornal do Brasil. Rio de Janeiro, 30 de junho de 1957, Suplemento Dominical.

. O pensamento de Sócrates II. In: Jornal do Brasil. Rio de Janeiro, 8 de julho de 1957, Suplemento Dominical.

. O pensamento de Sócrates III. In: Jornal do Brasil. Rio de Janeiro, 14 de julho de 1957, Suplemento Dominical.

. Panteísmo e Romantismo I. In: A Província do Pará. Belém, 14 de julho de 1957, Rodapé de Crítica.

. O pensamento de Sócrates IV. In: Jornal do Brasil. Rio de Janeiro, 21 de julho de 1957, Suplemento Dominical.

Panteísmo e Romantismo II. In: A Província do Pará. Belém, 21 de julho de 1957, Rodapé de Crítica.

. O pensamento de Sócrates V. In: Jornal do Brasil. Rio de Janeiro, 28 de julho de 1957, Suplemento Literário.

. Panteísmo e Romantismo III. In: A Província do Pará. Belém, 28 de julho de 1957, Rodapé de Crítica.

. Sócrates e a vida helênica. In: A Província do Pará. Belém, 18 de agosto de 1957, Rodapé de Crítica, p. 1.

As flores do mal I. In: Jornal do Brasil. Rio de Janeiro, 18 de agosto de 1957, Suplemento Dominical.

As flores do mal II. In: Jornal do Brasil. Rio de Janeiro, 25 de agosto de 1957, Suplemento Dominical.

A ontologia de Hartman I. In: A Província do Pará. Belém, 25 de agosto de 1957.

. Do fenômeno ao poético. In: Jornal do Brasil. Rio de Janeiro, 28 de agosto de 1957, Suplemento Dominical.

. Panteísmo e Romantismo I. In: Jornal do Brasil. Rio de Janeiro, 1- de setembro de 1957, Suplemento Dominical.

. O moderno Edgar Allan Poe. In: Jornal do Brasil. Rio de Janeiro, 20 de outubro de 1957, Suplemento Dominical, p.4. 
A ontologia de Hartman II. In: A Província do Pará. Belém, $1^{\circ}$ de setembro de 1957, Rodapé de Crítica.

. Panteísmo e Romantismo. In: Jornal do Brasil. Rio de Janeiro, $1^{\circ}$ de setembro de 1957, Suplemento Dominical.

. Panteísmo e Romantismo II. In: Jornal do Brasil. Rio de Janeiro, 8 de setembro de 1957, Suplemento Dominical.

- Panteísmo e Romantismo III. In: Jornal do Brasil. Rio de Janeiro, 15 de outubro de 1957, Suplemento Dominical.

- A filosofia e a metafísica I. In: A Província do Pará. Belém, 15 de setembro de 1957, Rodapé de Crítica.

. Filosofia e metafísica I. In: Jornal do Brasil. Rio de Janeiro, 29 de setembro de 1957, Suplemento Dominical.

. Filosofia e metafísica II. In: Jornal do Brasil. Rio de Janeiro, 6 de outubro de 1957, Suplemento Dominical.

. Filosofia e metafísica III. In: Jornal do Brasil. Rio de Janeiro, 13 de outubro de 1957, Suplemento Dominical.

. Platão e o conhecimento. In: Jornal do Brasil. Rio de Janeiro, 27 de outubro de 1957, Suplemento Dominical.

A crise da linguagem filosófica. In: Jornal do Brasil. Rio de Janeiro, 10 de novembro de 1957, Suplemento Dominical.

- Husserl e a Fenomenologia. In: Jornal do Brasil. Rio de Janeiro, 17 de novembro de 1957, Suplemento Dominical.

. Roteiro das meditações metafísicas de Descartes I. In: Jornal do Brasil. Rio de Janeiro, 17 de novembro de 1957, Suplemento Dominical.

. Roteiro das meditações metafísicas de Descartes II. In: Jornal do Brasil. Rio de Janeiro, 30 de novembro de 1957, Suplemento Dominical.

. A crítica do juízo estético. In: Jornal do Brasil. Rio de Janeiro, 30 de janeiro de 1958, Suplemento Dominical.

Platão e a poesia. In: Jornal do Brasil. Rio de Janeiro, 14 de fevereiro de 1958, Suplemento Dominical. 
. Jogo, forma e natureza. In: Jornal do Brasil. Rio de Janeiro, 6 de abril de 1958, Suplemento Dominical.

Apontamentos de estética. In: Jornal do Brasil. Rio de Janeiro, 6 de abril de 1958, Suplemento Dominical.

- A teoria do gênio em Kant e Schopenhauer. In: Jornal do Brasil. Rio de Janeiro, 27 de abril de 1958, Suplemento Dominical, p.6.

. Tempo e consciência histórica. In: Jornal do Brasil. Rio de Janeiro, 17 de agosto de 1958, Suplemento Dominical, p.4.

. Tempo e consciência histórica (Conclusão) In: Jornal do Brasil. Rio de Janeiro, 24 de agosto de 1958, Suplemento Dominical, p.4.

. Psicanálise e Arte I. In: Jornal do Brasil. Rio de Janeiro, 24 de agosto de 1958, Suplemento Dominical.

. Poesia e metafísica. In: Jornal do Brasil. Rio de Janeiro, 30 de agosto de 1958, Suplemento Dominical.

. Psicanálise e Arte II. In: Jornal do Brasil. Rio de Janeiro, 31 de agosto de 1958, Suplemento Dominical.

. Psicanálise e Arte III. In: Jornal do Brasil. Rio de Janeiro,7 de setembro de 1958, Suplemento Dominical.

. Imagem e idéia I. In: Jornal do Brasil. Rio de Janeiro, 30 de novembro de 1958, Suplemento Dominical.

Imagem e idéia II. In: Jornal do Brasil. Rio de Janeiro, 7 de dezembro de 1958, Suplemento Dominical.

. A origem da Tragédia e da Arte. In: Jornal do Brasil. Rio de Janeiro, 1958, Suplemento Dominical.

A ontologia de Hartman. In: Jornal do Brasil. Rio de Janeiro, 1958, Suplemento Dominical.

. Axiologia e moral; estudo sobre a ética de Hartman. In: Jornal do Brasil. Rio de Janeiro, 1958, Suplemento Dominical.

. O Drama da “Inteligência”. In: Jornal do Brasil. Rio de Janeiro, 7 de janeiro de 1959, Suplemento Dominical. 
A Previsão na História. In: Jornal do Brasil. Rio de Janeiro, 24 de janeiro de 1959, Suplemento Dominical.

. A Compreensão na história. In: Jornal do Brasil. Rio de Janeiro, 31 de janeiro de 1959, Suplemento Dominical.

. A Poética de Heidegger. In: Jornal do Brasil. Rio de Janeiro, 14 de fevereiro de 1959, Suplemento Dominical.

. Apontamentos de estética I. In: Jornal do Brasil. Rio de Janeiro, 14 de março de 1959, Suplemento Dominical.

. Apontamento de estética II. In: Jornal do Brasil. Rio de Janeiro, 28 de março de 1959, Suplemento Dominical.

. Notas de estudos sobre o Modernismo Brasileiro (ensaio). In: Jornal do Brasil. Rio de Janeiro, 1959, Suplemento Dominical.

. Panorama cultural: 1959. In: O Estado de S. Paulo. São Paulo, 31 de outubro de 1959, Suplemento Literário, p. 4.

. No caminho de Sófocles. In: O Estado de S. Paulo. São Paulo, 28 de novembro de 1959, Suplemento Literário, p. 4.

. Literatura Considerada como Filosofia. In: O Estado de S. Paulo. São Paulo, 21 janeiro de 1960, Suplemento Literário.

. Literatura Considerada como Filosofia. In: Folha do Norte. Belém, 23 de janeiro de 1960.

. Las Ciências Humanas y la Philosophia. In: O Estado de S. Paulo. São Paulo, 20 fevereiro de 1960, Suplemento Literário.

. Lucien Goldmann. In: O Estado de S. Paulo. São Paulo, 20 de fevereiro de 1960, Suplemento Literário.

. Ascese - Salvatores Dei. In: O Estado de S. Paulo. São Paulo, 05 de março de 1960, Suplemento Literário.

. O misticismo de Henry Miller. In: O Estado de S. Paulo. São Paulo, 21 de março de 1960, Suplemento Literário.

• “Les sequestré d’Altona”. In: O Estado de S. Paulo. São Paulo, 02 de abril de 1960, Suplemento Literário, p.5. 
. “Les sequestré d’Altona” II. In: O Estado de S. Paulo. São Paulo, 09 de abril de 1960, Suplemento Literário, p.5.

. Les sequestré d’Altona. In: Folha do Norte. Belém, 9 de abril de 1960.

. Crônica de Belém - Um capítulo da arqueologia amazônica. In: O Estado de S. Paulo. São Paulo, 30 de abril de 1960, Suplemento Literário, p.4.

. Imagem do sertão. In: O Estado de S. Paulo. São Paulo, 18 de junho de 1960, Suplemento Literário.

. Jean Paul Sartre - Critique de la raison dialectique. In: O Estado de S. Paulo. São Paulo, 25 de junho de 1960, Suplemento Literário.

. Le Rhinoceros. In: O Estado de S. Paulo. São Paulo, 30 de junho de 1960, Suplemento Literário.

. Reflexão sobre o teatro de Sartre. In: O Estado de S. Paulo. São Paulo, 03 de setembro de 1960, Suplemento Literário.

. George Lukács - La signification du Realisme Erotique. In: O Estado de S. Paulo. São Paulo, 10 de setembro de 1960.

. Crônica de Belém - Um novo retrato. In: O Estado de S. Paulo. São Paulo, 24 de dezembro de 1960, Suplemento Literário.

. Historicismo e Existencialismo. In: O Estado de S. Paulo. São Paulo, 1960, Suplemento Literário.

. Deux textes de Husserl sur le méthode et le science de la phenomenologie. In: $O$ Estado de S. Paulo. São Paulo, 28 de janeiro de 1961, Suplemento Literário.

. Uma concepção geográfica do mundo. In: O Estado de S. Paulo. São Paulo, 18 de fevereiro de 1961, Suplemento Literário, p.4.

. Leçons de philosophie de Simone Weil. In: O Estado de S. Paulo. São Paulo, 25 de fevereiro de 1961, Suplemento Literário.

. Crônica de Belém - "Belém do Grão Pará”. In: O Estado de S. Paulo, 25 de março de 1961, Suplemento Literário, p.4.

. A Crítica da razão dialética. In: Jornal do Brasil. Rio de Janeiro, 13 de maio de 1961, Suplemento Dominical, p. 4. 
A crítica da razão dialética I. In: Jornal do Brasil. Rio de Janeiro, 3 de junho de 1961, Suplemento Dominical, p. 1-2.

. A crítica da razão dialética II. In: Jornal do Brasil. Rio de Janeiro, 10 de junho de 1961, Suplemento Dominical, p. 3.

. A crítica da razão dialética III. In: Jornal do Brasil. Rio de Janeiro, 17 de junho de 1961, Suplemento Dominical, p. 6.

A crítica da razão dialética (final). In: Jornal do Brasil. Rio de Janeiro, 24 de junho de 1961, Suplemento Dominical, p. 2.

. Eduardo Nicole: Historicismo e Existencialismo. In: O Estado de S. Paulo. São Paulo, 1961, Suplemento Literário.

. Biedermann e os Incendiários - I . In: O Estado de S. Paulo. São Paulo, 19 de maio de 1962, Suplemento Literário, p.5.

. Biedermann e os Incendiários - II . In: O Estado de S. Paulo. São Paulo, 26 de maio de 1962, Suplemento Literário, p.5.

. A destruição da estética. In: O Estado de S. Paulo. São Paulo, 08 de dezembro de 1962, Suplemento Literário.

. Paul Nizan - Les Chiens de Garde. In: O Estado de S. Paulo. São Paulo, 1962, Suplemento Literário.

. La Philosophie en question - Pierre Fougeyrellas. In: O Estado de S. Paulo. São Paulo, 1962, Suplemento Literário.

. O misticismo de Kazantzakis. In: O Estado de S. Paulo. São Paulo, 1962, Suplemento Literário.

. A vida nos bastidores. In: O Estado de S. Paulo. São Paulo, 1962, Suplemento Literário.

. O Modernismo na História das Vanguardas. In: O Estado de S. Paulo. São Paulo, 1962, Suplemento Literário.

- Martin Heidegger - Approche de Hölderlin. In: O Estado de S. Paulo. São Paulo, 1962, Suplemento Literário.

O Menino. In: O Estado de S. Paulo. São Paulo, 2 de fevereiro de 1963, Suplemento Literário, p.4. 
Filosofia - La consciencia moral de Homero a Demócrito y Epicuro. In: $O$ Estado de S. Paulo. São Paulo, 3 de agosto de 1963, Suplemento Literário.

. A metafísica engraçada. In: O Estado de S. Paulo. São Paulo, 07 de setembro de 1963, Suplemento Literário, p. 4.

. A metafísica engraçada. In: O Estado de Minas. Belo Horizonte.

. Guimarães Rosa e a tradução. In: O Estado de S. Paulo. São Paulo, 14 de setembro de 1963, Suplemento Literário, p.3.

. Fernando Pessoa e a metafísica. In: O Estado de Minas. Belo Horizonte, 6 de outubro de 1963.

. Guimarães Rosa e a tradução. In: O Estado de Minas. Belo Horizonte, 27 de outubro de 1963.

A esperança na educação. In: O Estado de S. Paulo. São Paulo, 1963, Suplemento Literário.

. Sartre e a Crítica da razão dialética. In: O Estado de Minas. Belo Horizonte, 16 de janeiro de 1964, p.4.

. Platão e a poesia. In: O Estado de Minas. Belo Horizonte, 8 de março de 1964, p.4.

. Sob as ordens de mamãe. In: O Estado de S. Paulo. São Paulo, 16 de maio de 1964, Suplemento Literário, p.1.

A crise da filosofia messiânica. In: O Estado de S. Paulo. São Paulo, 24 de outubro de 1964, Suplemento Literário, p.6.

. O amor na obra de Guimarães Rosa. In: O Estado de S. Paulo. São Paulo, 27 março de 1965, Suplemento Literário, p.2.

. A náusea em Clarice Lispector. In: O Estado de S.Paulo. São Paulo, 24 de julho de1965, Suplemento Literário, p.3.

. A paixão segundo G. H. In: O Estado de S. Paulo. São Paulo, 04 de setembro de 1965, Suplemento Literário, p.1.

. O jogo da linguagem - I. In: O Estado de S. Paulo. São Paulo, 20 de novembro de1965, Suplemento Literário, p.6. 
. O jogo da linguagem II. In: O Estado de S.Paulo. São Paulo, 27 de novembro de 1965, Suplemento Literário, p.4.

. A vida nos bastidores. In: O Estado de S. Paulo. São Paulo, 12 de março de 1966, Suplemento Literário, p.5.

. Introdução ao fim. In: O Estado de S. Paulo. São Paulo, 9 julho de 1966, Suplemento Literário, p.2.

. A prosa de Fernando Pessoa. In: O Estado de S. Paulo. São Paulo, $1^{-}$-de outubro de 1966, Suplemento Literário, p.6.

. O ocultismo na poesia de Fernando Pessoa. In: O Estado de S. Paulo. São Paulo, 22 de outubro de 1966, Suplemento Literário, p.1.

. Paradoxo e verdade. In: O Estado de S. Paulo. São Paulo, 12 de novembro de 1966, Suplemento Literário, p.1.

. A máquina do poema. In: O Estado de S. Paulo. São Paulo, 3 de dezembro de 1966, Suplemento Literário, p.3.

. A Viagem. In: O Estado de S. Paulo. São Paulo, 24 dezembro de 1966, Suplemento Literário, p.6.

. Páginas íntimas de Pessoa. In: O Estado de S. Paulo. São Paulo, 11 de janeiro de 1967, Suplemento Literário.

. Psicologia da criação. In: O Estado de S. Paulo. São Paulo, 25 de fevereiro de 1967, Suplemento Literário, p.1.

. Um poeta solitário. In: O Estado de S. Paulo. São Paulo, 1- de abril de 1967, Suplemento Literário, p.3.

A marcha das utopias. In: O Estado de S. Paulo. São Paulo, 8 de abril de 1967, Suplemento Literário.

. A viagem. In: Jornal do Comércio. Rio de Janeiro, 21 de maio de 1967.

. A propósito de um triptico. In: O Estado de S. Paulo. São Paulo, 8 de julho de 1967, Suplemento Literário.

. A escola do Recife. In: O Estado de S. Paulo. São Paulo, 15 de julho de 1967, Suplemento Literário. 
A esperança na educação. In: $O$ Estado de Minas Gerais. Edição de Aniversário. Belo Horizonte, 2 de setembro de 1967, Suplemento Literário, p.4.

. De consolatione philosophiae. In: O Estado de S. Paulo. São Paulo, 7 de outubro de 1967, Suplemento Literário.

. Tutaméia. In: O Estado de S. Paulo. São Paulo, 1967, Suplemento Literário.

A Paixão de um romancista. In: O Estado de S. Paulo. São Paulo, 1967, Suplemento Literário.

. A Viagem do Grivo. In: O Estado de S. Paulo. São Paulo, 1967, Suplemento Literário.

À margem do Estruturalismo. In: O Estado de S. Paulo. São Paulo, 6 de janeiro de 1968, Suplemento Literário, p.1.

. A metáfora lancinante. In: O Estado de S. Paulo. São Paulo, 13 de janeiro de 1968, Suplemento Literário, p.1.

A superação da filosofia I. In: O Estado de S. Paulo. São Paulo, 24 de fevereiro de 1968, Suplemento Literário.

. A superação da filosofia II. In: O Estado de S. Paulo. São Paulo, 2 de março de 1968, Suplemento Literário, p.1.

- Vertentes. In: O Estado de S. Paulo. São Paulo, 23 de março de 1968, Suplemento Literário, p.1.

. A marcha das utopias. In: O Estado de Minas Gerais. Belo Horizonte, 13 de abril de 1968, Suplemento Literário, p.12.

. Das Utopias. In: O Estado de S. Paulo. São Paulo, 18 de maio de 1968, Suplemento Literário, p.3.

. Espacialismo e poesia concreta. In: O Estado de S. Paulo. São Paulo, 16 de junho de 1968, Suplemento Literário.

. Poética de Murilo. In: O Estado de Minas Gerais. Belo Horizonte, 29 de julho de 1968, Suplemento Literário.

. Textos filosóficos de Fernando Pessoa. In: O Estado de S. Paulo. São Paulo, 10 de agosto de 1968, Suplemento Literário, p.1. 
. Arqueologia da arqueologia I. In: O Estado de S. Paulo. São Paulo, 5 de outubro de 1968, Suplemento Literário.

Arqueologia da arqueologia II. In: O Estado de S. Paulo. São Paulo, 19 de outubro de 1968, Suplemento Literário.

. Arqueologia da arqueologia III. In: O Estado de S. Paulo. São Paulo, 26 de outubro de 1968, Suplemento Literário.

. Arqueologia da arqueologia (conclusão). In: O Estado de S. Paulo. São Paulo, 2 de novembro de 1968, Suplemento Literário.

. Guimarães Rosa em novembro. In: O Estado de Minas Gerais. Belo Horizonte, 26 de novembro de 1968, Suplemento Literário, p.1-2.

A Rosa o que é de Rosa. In: O Estado de S. Paulo. São Paulo, 22 de março de 1969, Suplemento Literário, p.1.

Anarquismo intelectual. In: O Estado de S. Paulo. São Paulo, 26 de abril de 1969, Suplemento Literário, p.3.

. O modernismo e as vanguardas (acerca do canibalismo literário) I. In: O Estado de Minas Gerais. Belo Horizonte, 26 de abril de 1969, Suplemento Literário, p.4.

. O modernismo e as vanguardas (acerca do canibalismo literário) II. In: O Estado de Minas Gerais. Belo Horizonte, 3 de maio de 1969, Suplemento Literário, p.7.

. O modernismo e as vanguardas (acerca do canibalismo literário) III. In: O Estado de Minas Gerais. Belo Horizonte, 10 de maio de 1969, Suplemento Literário, p.6-7.

. O modernismo e as vanguardas (acerca do canibalismo literário) IV. In: O Estado de Minas Gerais. Belo Horizonte, 17 de maio de 1969, Suplemento Literário, p.6-7.

. Gênese e estrutura. In: O Estado de S. Paulo. São Paulo, 20 de setembro de 1969, Suplemento Literário, p.1.

. Heidegger e a política - I. In: O Estado de S. Paulo. São Paulo, 04 de outubro de 1969, Suplemento Literário, p.1.

. Heidegger e a política - II. In: O Estado de S. Paulo. São Paulo, 11 de outubro de 1969, Suplemento Literário, p.1.

. Vertentes - I. In: O Estado de S. Paulo. São Paulo, 08 de novembro de 1969, Suplemento Literário, p.1. 
. Vertentes - II (Conclusão). In: O Estado de S. Paulo. São Paulo, 15 de novembro de 1969, Suplemento Literário, p.6.

- À margem de uma lembrança. In: O Estado de S. Paulo. São Paulo, 27 de dezembro de 1970, Suplemento Literário, p.3.

. Carlos Drummond de Andrade: a morte absoluta. In: O Estado de S. Paulo. São Paulo, 3 de janeiro de 1971, Suplemento Literário, p.5.

. Carlos Drummond de Andrade: a morte absoluta - 2. In: O Estado de S. Paulo. São Paulo, 10 de janeiro de 1971, Suplemento Literário, p.3.

- Apollinaire, Cendras e Oswald I. In: O Estado de S. Paulo. São Paulo, 7 de fevereiro de 1971, Suplemento Literário, p.1.

Apollinaire, Cendras e Oswald II. In: O Estado de S. Paulo. São Paulo, 14 de fevereiro de 1971, Suplemento Literário, p.1.

Atualidade da estética de Hegel. In: O Estado de S. Paulo. São Paulo, 21 de fevereiro de 1971, Suplemento Literário, p.3.

. O misticismo de Heidegger. In: O Estado de S. Paulo. São Paulo, 12 de setembro de 1971, Suplemento Literário, p.1.

. Homem de muita fé. In: O Estado de S. Paulo. São Paulo, 10 de outubro de 1971, Suplemento Literário, p.1.

. Ponta de Lança. O Estado de S. Paulo. São Paulo, 21 de novembro de 1971, Suplemento Literário, p.1.

O Modernismo na História das Vanguardas. In: O Estado de S. Paulo. São Paulo, 2 de dezembro de 1971, Suplemento Literário.

. A crise da filosofia messiânica. In: O Estado de S. Paulo. São Paulo, Suplemento Literário, p.6.

. O Retorno à Antropofagia. In: O Estado de S. Paulo. São Paulo, 26 de dezembro de 1971, Suplemento Literário.

Apresentação de Murilo Mendes. In: O Estado de Minas Gerais. Belo Horizonte, 29 de julho de 1972, Suplemento Literário, p.2.

. Mário Faustino revisitado. In: Folha de S. Paulo. São Paulo, 7 de novembro de 1972, Folhetim. 
Introdução à crise da cultura I. In: O Estado de Minas Gerais. Belo Horizonte, 11 de agosto de 1973, Suplemento Literário, p.2.

. Introdução à crise da cultura II. In: O Estado de Minas Gerais. Belo Horizonte, 18 de agosto de 1973, Suplemento Literário, p.4-5.

- Introdução à crise da cultura III. In: O Estado de Minas Gerais. Belo Horizonte, 25 de agosto de 1973, Suplemento Literário.

. Drummond - poeta anglo-francês. In: O Estado de S. Paulo. São Paulo, 2 de setembro de 1973, Suplemento Literário, p.1.

. A viagem do Grivo. In: O Estado de Minas Gerais. Belo Horizonte, 6 abril de 1974, Suplemento Literário, p. 4-5.

. Vertentes. In: O Estado de Minas Gerais. Belo Horizonte, 3 de agosto de 1974, Suplemento Literário, p.1-3.

. Cultura e ficção - a interiorização do carnaval na literatura moderna. In: $O$ Estado de S. Paulo. São Paulo, 22 de setembro de 1974, Suplemento Literário, p. 6.

. Comentário de “As projeções do ideológico”, de Luiz Costa Lima. In: $O$ Estado de S. Paulo. São Paulo, 17 de novembro de 1974, Suplemento Literário, p. 3.

. O mito Jean-Paul Sartre. In: Jornal Nanico - núcleo de apoio de notícias e idéias de comunicação. Belém, ano II, maio de 1980, p.5.

. Por que ler Hegel, hoje. In: O Estado de S. Paulo. São Paulo, 4 de novembro de 1981, Suplemento Cultura, p.12-14.

. Platão no Brasil. In: O Estado de S. Paulo. São Paulo, 7 de fevereiro de 1982, Suplemento Cultura, p.7.

. A paixão de Clarice Lispector. In: Diário Oficial. Belém-Pará, ano 1, n¹, 22 de fevereiro de 1982, Suplemento Cultural, p.1-8.

. Por que ler Heidegger hoje. In: O Estado de S. Paulo. São Paulo, 1982, Suplemento Cultura.

. O universo filosófico e ideológico do Barroco. In: O Liberal. Belém, 15 de novembro de $1983,3^{\circ}$ Caderno.

. Duas ou três coisas que ela sabe de João Cabral (resenha para o livro de Marta Peixoto). In: Folha de S. Paulo. São Paulo, 24 de junho de 1984. 
. Mário Faustino revisitado. In: Floretim. Teresina, junho-julho de 1984.

- Cancioneiro do Quilombo de Palmares (resenha para o livro de Domício Proença Filho). In: O Estado de S. Paulo. São Paulo, 16 de setembro de 1984.

. Nietzsche - Andarilho do conhecer. In: Folha de S. Paulo. São Paulo, 9 de fevereiro de 1985.

. O nazismo de Heidegger. In: Jornal do Brasil. Rio de Janeiro, fevereiro de 1989, Caderno B.

- Estorvo é o relato exemplar de uma falha (resenha para o livro de Chico Buarque). In: Folha de S. Paulo. São Paulo, 3 de agosto de 1991, Ilustrada.

A privatização do erário (co-autoria com Armando Mendes). In: O Liberal. Belém, 13 de junho de 1993.

Sócrates construtor. In: Folha de S. Paulo. São Paulo, 13 de setembro de 1996, Jornal de Resenhas, p.8.

. Leitura filosófica de Guimarães Rosa. In: O Estado de Minas Gerais - 30 anos de Guimarães Rosa - Arquivo. Belo Horizonte, novembro de 1996, n 19, Suplemento Belo Horizonte, Secretaria de Estado da Cultura de Minas Gerais, p.20-21-22.

. A voz inaudível de Deus. In: O Liberal. Belém, 30 de março de 1997, Cartaz, p.4.

. Poesia brasileira em exame. In: O Estado de Minas Gerais. Belo Horizonte, agosto de 1997, $\mathrm{n}^{\circ}$ 28, Suplemento Belo Horizonte, Secretaria de Estado da Cultura de Minas Gerais, p.21-22-23.

. Clarice Lispector ou os destroços da introspecção. In: O Liberal. Belém, 8 de janeiro de 1998, s./p.

. Barroco: crônica de uma sedução. In: O Estado de Minas Gerais. Belo Horizonte, fevereiro de 1998, Suplemento Literário, p.3-7.

. Creio que se possa unir socialismo e democracia. Entrevista. In: O Liberal. Belém, 19 de abril de 1998, Cartaz, p.4-5.

. Nós somos um diálogo. In: Folha de S. Paulo. São Paulo, 8 de agosto de 1998, Jornal de Resenhas, n.41, p.10.

. Mestre da palavra e o humanismo. In: O Liberal. Belém, 17 outubro de 1999, p.3. 
. Trágica dialética da lembrança. In: Folha de S. Paulo. São Paulo, 25 de julho de 1999, Caderno Mais!

. Três questões sobre Nietzsche. In: Folha de S. Paulo. São Paulo, 6 de agosto de 2000. Caderno Mais!

. Benedito Nunes diz: Nietzsche não passará. In: O Liberal. Belém, 21 agosto de 2000, Cartaz, p.5.

. UFPA relança A República. In: O Liberal. Belém, 5 setembro de 2000, Cartaz, p.1.

. Linhas da inquietação. In: Folha de S. Paulo. São Paulo, $1^{\circ}$ de setembro de 2002. Caderno Mais!, p.10-11.

A via-crúcis da estrela (resenha sobre a coletânea Outros escritos, de Teresa Montero e Lícia Manzo, e Clarice Lispector com a ponta dos dedos, de Vilma Arêas). In: Folha de S. Paulo. São Paulo, 16 de outubro de 2005, Caderno Mais!, p.7.

$\underline{\text { Textos em revistas diversas e periódicos acadêmicos no Brasil }}$

Nunes, Benedito. Poemas. In: Encontro. Belém, $2^{0}$ trimestre, nº $^{\circ} 1,1948$.

. Considerações sobre “A Peste”. In: Revista Norte. Belém, vol.1, n¹, fevereiro, 1952, p. 3-9.

. Hécuba. In: Revista Norte. Belém, vol.1, n 1, fevereiro, 1952, p.64-5.

Atualidade de São Tomaz. In: Revista Norte. Belém, Ano I, nº . 2, marçoabril, 1952.

As idéias do Existencialismo. In: Revista Norte. Belém, 1952.

O drama da inteligência. In: Revista da Faculdade de Direito do Pará.

Belém, 1959.

O espírito filosófico. In: Revista da Faculdade de Letras. Belém, 1960.

. A literatura no Pará. In: Anuário da literatura brasileira. Rio de Janeiro, Editora Gráfica do Livro, ano 2, n-2, 1961.

- Conceito de forma e estrutura literária. In: Revista de Estudos Universitários. Universidade Federal de Pernambuco, Recife, vol.1, julho-setembro, 1962. 
O projeto de Mário Faustino. In: Revista Invenção. São Paulo, 2 (3), junho, 1963, p. 20-26.

. A dialética de Sartre. In: Revista de Educação e Letras. Belém, junho, 1963.

. Existencialismo e Marxismo. In: Revista de Estudos Universitários. Universidade Federal de Pernambuco, Recife,1964.

. Farias Brito. In: Separata da Revista do Livro. Rio de Janeiro, ${ }^{\circ}{ }^{-25}$, março de 1964.

. O amor na obra de Guimarães Rosa. In: Revista do Livro. Rio de Janeiro, vol.7, $\mathrm{n}^{\circ}-26$, setembro, 1964, p. 39-62.

. Os cadernos de cultura. In: A marcha das utopias. Rio de Janeiro: MEC, 1966.

. Os outros de Fernando Pessoa. In: Comentário. Rio de Janeiro, vol. 7, $\mathrm{n}^{-}$2, abril-junho, 1966, p. 173-85.

A propósito de um tríptico. In: Revista Brasileira de Filosofia. São Paulo, 15 (67), julho-agosto-setembro de 1967, p.295-299.

Fernando Pessoa: páginas íntimas e de auto interpretação e páginas de estética e de teoria e crítica literária. In: Revista Brasileira de Filosofia. São Paulo, 17 (69), 1967.

. Os outros de Fernando Pessoa. In: Revista Comentário. Rio de Janeiro, 1967.

. A validade da Estética de Hegel. In: Revista Comentário. Rio de Janeiro, 1970.

Ernst Cassirer: Antropologia filosófica - introduccion a una filosofia de la cultura. In: Boletim Informativo da Biblioteca Central da Universidade Federal do Pará. Belém, 01 (01), agosto de 1971, p.28-30.

- Merleau Ponty - o visível e o invisível. In: Boletim Informativo da Biblioteca Central da Universidade Federal do Pará. Belém, (06), janeiro, 1973, p.80-82.

Jacques Derrida: A Escritura e a Diferença. In: Boletim Informativo da Biblioteca Central da Universidade Federal do Pará. Belém, 02 (02), abril, 1973, p.39-41. 
Um conceito de cultura. In: Revista da Universidade Federal do Pará. Belém, 3 (3), 1973, p.9-29.

. Fingir para compreender - filosofia e poesia na obra de Fernando Pessoa. In: Anais do XV Seminário de Verão - 50 anos de Literatura Portuguesa (1923-1973). Recife, Associação de Estudos Portugueses Jordão Emerenciano, 1974.

. Comentário a As projeções do ideológico. In: Caderno da PUC. I Encontro Nacional de Professores de Literatura, Rio de Janeiro, n-26, 1975, p.205-213.

. Música e literatura. In: Revista da Universidade Federal do Pará. Belém, ano $5, \mathrm{n}^{-} 5,1975$.

. Literatura e Fenomenologia. In: Boletim de Ariel. Rio de Janeiro, nº $^{-}$11, 1975. Uma interpretação de Sartre. In: Boletim de Ariel. Rio de Janeiro, n-12, 1975. . Literatura e Filosofia: análise de Grande Sertão Veredas, de João Guimarães Rosa. In: Cadernos da PUC. II Encontro Nacional de Professores de Literatura, Rio de Janeiro, $\mathrm{n}^{-}$28, 1976, p.7-24.

. O carro dos milagres. In: Revista José. Rio de Janeiro, $\mathrm{n}^{-}$4, p.27-8, outubro, 1976. . Educação Artística e Filosofia da Arte. In: MEC-FUNARTE-INAP/EAB. Série n.1. Rio de Janeiro, Projeto: “A função reativadora das artes plásticas na educação”, 1976. . Memórias de Ralfo. In: Revista José. Rio de Janeiro, n-7, 1977. A vontade de saber. In: Revista José. Rio de Janeiro, n-10, julho, 1978. . Publicação do debate acerca da Crítica e Poesia. In: Remate de Males. Campinas, IEL/UNICAMP, 1981.

As linhas do debate. In: Cadernos do CFCH. Revista do Centro Filosofia e Ciências Humanas da Universidade Federal do Pará. Belém, n ํㅜ 3, março, 1982, p.103-7.

. O discurso de Heidegger em Ser e Tempo e a Questão da Linguagem. In: Revista Filosófica Brasileira. Rio de Janeiro, n-1, dezembro de 1982.

. O universo ideológico e filosófico do Barroco. In: Revista Barroco. Belo Horizonte, $\mathrm{n}^{\circ} 12,1982 / 1983$. 
. Réquiem alemão para a filosofia. In: Tempo Brasileiro. Rio de Janeiro, $n^{\circ} 75$, outubro-dezembro, 1983.

. Publicação dos Anais do Seminário Novas Tecnologias da Comunicação e a Cultura. In: Fundação João Pinheiro. Belo Horizonte, 1984.

Filosofia: textos escolhidos. Coletânia organizada por Bendito Nunes, com colaboração dos Profs. do Curso de Filosofia da UFPA. Belém: Centro de Filosofia e Ciências Humanas, 1985.

. Conceito de formas e estrutura literária. In: Revista da Universidade Federal de Pernambuco. Recife, $\mathrm{n}^{\circ} 1$ e 2, janeiro-junho, 1985.

Personimagem. In: Revista de Estudos Portugueses e Africanos. Campinas, IEL/UNICAMP, $\mathrm{n}^{-}$- 8, 2-- sem., 1986.

Antropofagismo e Surrealismo. In: Revista Remate de Males. Campinas, IEL/UNICAMP, $\mathrm{n}^{\circ}$ 6, 1986.

A poética de Mario Faustino: criação e aprendizagem. In: Cadernos de Teresina. Teresina, vol. 1, $\mathrm{n}^{\circ}$ 1, abril, 1987, p.11-6.

Clarice Lispector ou o naufrágio da introspecção. In: Revista Remate de Males. Campinas, IEL/UNICAMP, $\mathrm{n}^{-}$9, edição organizada por Berta Waldman e Vilma Arêas; Departamento de Teoria Literária, maio de 1989.

Filosofia e memória. In: Revista de Cultura do Pará. Belém, vol. 10, n-1, p.710, Junho, 1989. Trabalho apresentado no Fórum de Ciência e Cultura sobre o tema "Cultura e Memória”, UFRJ, p.7-10.

- Machado de Assis e a Filosofia. In: Revista Travessia. Florianópolis, Universidade Federal de Santa Catarina, 1989.

. Encontro em Austin. In: Revista USP - Dossiê Razão e desrazão -. São Paulo, n⿳0 11 , setembro-outubro-novembro, 1991, p.150-3.

A recente poesia brasileira: expressão e forma. In: Novos Estudos CEBRAP. São Paulo, Centro Brasileiro de Análise e planejamento, n 31, outubro, 1991, p.171-83.

- Filosofia e Literatura. In: Revista da Associação brasileira de Literatura Comparada/ABRALIC, 1993. 
Filosofia e Tragédia: labirintos. In: Filosofia/Política - O trágico. Nㄱ, L\&PM Editores, 1993.

. Encontros com Alexandre Eulálio. In: Revista Remate de Males. Campinas, IEL/UNICAMP, junho, 1993.

. Recordando Max Boudin. In: Boletim do Museu Paraense Emílio Goeldi. Belém, Série Antropologia, vol.9, nำ 1, p, 1994, 145-150.

. Casa, Praça, Jardim e Quintal. In: Ciência e Trópico. Fundação Joaquim Nabuco, vol. 22, $\mathrm{n}^{\circ}$ 2, julho-dezembro, 1994.

. Ética e leitura. Leitura; Teoria e Prática. In: Mercado Aberto. Associação de leitura do Brasil, ano 15, n² 27, junho, 1996.

- Leitura filosófica de Guimarães Rosa. In: Arquivo Suplemento Literário de Minas Gerais - SEC, $\mathrm{n}^{\circ}$ 19, p. 20-2, novembro, 1996.

. Poesia de mão dupla. In: Exu Documento. Salvador: Fundação Casa de Jorge Amado, 1997.

. Os destroços da introspecção. In: ZILBERMAN, Regina et al. Clarice Lispector: a narração do indizível. Porto Alegre: Artes e Ofícios/Edipuc/Instituto Cultural Judaico Marc Chagall, 1998, p.35-48.

. O mito em Grande Sertão: Veredas. In: Scripta - Revista do Programa de Pós-Graduação em Letras e do Centro de Estudos Luso-afro-brasileiros da PUC/Minas. Belo Horizonte, vol. 2, $\mathrm{n}^{\circ}$ 3, $2^{\circ}$ sem., 1998, p.33-40.

. Ocaso da literatura ou falência da crítica? In: Revista Língua e Literatura. São Paulo, USP - Departamento de Letras, nº 24, 1999, p.11-21.

. Crítica literária no Brasil, ontem e hoje. In: Revista Cult. São Paulo, n 26, setembro, 1999, p.20-24.

História e ontologia (Da essência da técnica). In: Natureza Humana: Revista Internacional de Filosofia e Práticas Psicoterápicas/ Grupo de Pesquisa em Filosofia e Práticas e Psicoterápicas do Programa de Estudos Pós-Graduados em Psicologia Clínica da PUC-SP. São Paulo, vol. 1, n-1, 1999, p.15-31.

Heidegger e a poesia. In: Natureza Humana: Revista Internacional de Filosofia e Práticas Psicoterápicas/ Grupo de Pesquisa em Filosofia e Práticas e Psicoterápicas 
do Programa de Estudos Pós-Graduados em Psicologia Clínica da PUC-SP. São Paulo, vol. 2, $\mathrm{n}^{\circ}$ 1, 2000, p.103-127.

. Crítica literária no Brasil, ontem e hoje. In: MARTINS, Maria Helena (org.). Rumos da crítica. São Paulo: Editora SENAC/Itaú Cultural, 2000.

. Andarilho do conhecer. In: Tempo Brasileiro. Rio de Janeiro, $\mathrm{n}^{\mathbf{0}}$ 143, outubrodezembro, 2000, p.81-7.

. A questão do outro em Heidegger. In: Natureza Humana: Revista Internacional de Filosofia e Práticas Psicoterápicas/ Grupo de Pesquisa em Filosofia e Práticas e Psicoterápicas do Programa de Estudos Pós-Graduados em Psicologia Clínica da PUC-SP. São Paulo, vol.3, n-1, janeiro-junho de 2001, p.51-7.

Paris n’América. In: Asas da Palavra - Revista do Curso de Letras - Centro de Ciências Humanas e Educação - UNAMA - Universidade da Amazônia - vol. 6, $\mathrm{n}^{\circ}$ 12, julho de 2001, p. 38-49.

. História e ontologia. In: Humanitas. Revista do Centro de Filosofia e Ciências Humanas da Universidade Federal do Pará. Belém, vol. 17, nº 1/2, janeiro-dezembro, 2001, p.45-54.

. Max Martins, Mestre-Aprendiz. In: Asas da Palavra - Revista do Curso de Letras - Centro de Ciências Humanas e Educação - UNAMA - Universidade da Amazônia vol. 5, $\mathrm{n}^{\mathrm{0}}$ 11, julho, 2002, p.13-35.

. Haroldo Maranhão. In: Asas da Palavra - Revista do Curso de Letras - Centro de Ciências Humanas e Educação - UNAMA - Universidade da Amazônia - vol. 6, n-13, junho, 2002, p.11-13.

. Drummond, poeta anglo-francês. In: Asas da Palavra - Revista do Curso de Letras - Centro de Ciências Humanas e Educação - UNAMA - Universidade da Amazônia vol. 6, $\mathrm{n}^{\mathrm{o}}$ 14, dezembro, 2002, p.31-6.

. Carlos Drummond: a morte absoluta. In: Revista da Biblioteca Mário de Andrade - Carlos Drummond de Andrade - 100 anos. São Paulo, vols. 60/61, janeirodezembro, 2002/2003, p.18-29.

. O verso visionário de Mário Faustino. In: Revista Bravo!, nº 61, outubro de 2002, p.87-9. 
Dois mestres e uma só lembrança. In: Revista Cult. Pará, vol. 14, nº 1, janeiro, 2003, p.7-9.

Antropofagia e vanguarda - acerca do canibalismo literário. In: Revista Literatura e Sociedade - Departamento de Teoria Literária e Literatura Comparada da USP -, São Paulo, n 7 , 2003/2004.

. Dalcídio Jurandir: as oscilações de um ciclo romanesco. In: Asas da PalavraRevista do Curso de Letras - Centro de Ciências Humanas e Educação - UNAMA Universidade da Amazônia - vol. 8, n-17, junho, 2004, p.15-21.

. Physis Natura - Heidegger e Merleau-Ponty. In: Natureza Humana: Revista Internacional de Filosofia e Práticas Psicoterápicas/ Grupo de Pesquisa em Filosofia e Práticas e Psicoterápicas do Programa de Estudos Pós-Graduados em Psicologia Clínica da PUC-SP. São Paulo, vol.6, n-2, julho-dezembro, 2004, p.271-287.

. Encontro em Austin. In: MOTTA Leda Tenório (org.). Céu acima. São Paulo: Pespectiva/FAPESP, 2005.

Fábula e biografia de Dom Quixote e Sancho Pança. In: Asas da Palavra Revista do Curso de Letras - Centro de Ciências Humanas e Educação - UNAMA Universidade da Amazônia - vol. 9, n² 20, julho de 2005, p.24-7.

O niilismo e o pensamento poético. In: Revista PZZ - Arte, Política e Cultura. Belém-Pará, ano II, $\mathrm{n}^{\circ}$ 3, abril-maio, 2006, p.8-17.

$\underline{\text { Textos em revistas diversas e periódicos acadêmicos no exterior }}$

NUNES, Benedito. Consideraciones sobre la reduccion Sociológica. In: La reduccion Sociológica. RAMOS, Guerrero. 1. ed., n. 5, Universidade Nacional Autonoma do México, 1959.

Literatura Moderna no Brasil. In: Revista di Filosofia e di Cultura, AutAut. Laupugnani Nigri Editore, Milão, Itália, 1967.

. Literatura Moderna no Brasil. In: Revista di Filosofia e di Cultura, Aut-Aut. Laupugnani Nigri Editore, Milão, Itália, 1967.

La Marcha de Las Utopias. In: Revista de Cultura Brasileira. Madrid (26), p. 271-277, setembro, 1968. 
Aspetti della prosa brasiliana contemporanea. In: Revista di Filosofia e di Cultura, Aut Aut. Lampugnani Nigri Editore, Milão, Itália, $\mathrm{n}^{-}$109-110, p.116-123, janeiromarço, 1969.

. A Rosa o que é de Rosa. In: Etc. Lisboa, Portugal, 26 de janeiro de 1969, p. 1-8.

Pessoa, Textos filosóficos. In: Diário de Lisboa. Lisboa, Portugal, 13 de fevereiro de 1969, Suplemento Literário, p.3.

. Tutaméia. In: Revista de Letras. Porto Rico, p.304-310, junho, 1969.

Os outros de Fernando Pessoa. In: Bulletin de l'Institute d'Études Portugaises et brésiliennes de la Sorbonne. Paris, França, p.335-338, 1970.

Affonso Ávila: código de Minas \& Poesia Anterior. In: Colóquio/Letras, Lisboa, Portugal, nº 3 , p.89-90, setembro, 1971.

. Os condenados, de Oswald de Andrade. In: Colóquio/Letras, Lisboa, Portugal, $\mathrm{n}^{-}$4, dezembro, 1971.

- Aracy Amaral: Blaise Cendrars no Brasil e os Modernistas. In: Colóquio/Letras, Lisboa,Portugal, $\mathrm{n}^{\circ}$ 6, março, 1972.

. História e Ideologia. In: Colóquio/Letras, Lisboa, Portugal, n 7, maio, 1972.

. Saudades do Carnaval. In: Colóquio/Letras. Lisboa, Portugal, $\mathrm{n}^{-}$13, p.90-1, maio, 1973.

. Benedito Monteiro: Verde vagomundo. In: Colóquio/Letras. Lisboa, Portugal, $\mathrm{n}^{\circ}$ 14, p. 94-5, junho, 1973.

. Max Martins: H’era. In: Colóquio/Letras. Lisboa, Portugal, $\mathrm{n}^{\circ}$ 15, p. 92-3, setembro, 1973.

. A transgressão do texto. In: Colóquio/Letras. Lisboa, Portugal, n-15, p. 967, setembro, 1973.

Armando Freitas Filho: Marca registrada. In: Colóquio/Letras. Lisboa, Portugal, $\mathrm{n}^{-}$18, março, 1974.

. Água Viva, de Clarice Lispector. In: Colóquio/Letras. Lisboa, Portugal, $\mathrm{n}^{-}$ 19, maio, 1974. 
Poesia e filosofia na obra de Fernando Pessoa. In: Colóquio/Letras. Lisboa, Portugal, $\mathrm{n}^{0}$ 20, julho, 1974.

. Cidade Calabouço, de Rui Mourão. In: Colóquio/Letras. Lisboa, Portugal, nº 21, setembro, 1974.

. Um dia de ver as coisas, de Dora Ferreira da Silva. In: Colóquio/Letras. Lisboa, Portugal, n-23, p.92-3, janeiro, 1975.

. A metáfora do corpo no romance naturalista. In: Colóquio/Letras. Lisboa, Portugal, n- 23, p.100-1, janeiro. 1975.

. A metamorfose do silêncio, de Luiz Costa Lima. In: Colóquio/Letras. Lisboa, Portugal, nํㅡㄹ 24, março, 1975.

. O tempo e outros remorsos, de Alcides Villaça:. In: Colóquio/Letras. Lisboa, Portugal, $\mathrm{n}^{\circ}$ 26, p.96-97, julho, 1975.

. O Convidado, de Murilo Rubião. In: Colóquio/Letras. Lisboa, Portugal, $\mathrm{n}^{-}$ 28, novembro, 1975.

. Obra em Prosa de Fernando Pessoa. In: Colóquio/Letras. Lisboa, Portugal, $\mathrm{n}^{\circ}$ 35, janeiro, 1977.

- A estética de Lévi-Strauss, de José Guilherme Merquior. In: Colóquio/Letras. Lisboa, Portugal, nº 36, março, 1977.

Xadrez de estrelas, de Haroldo de Campos. In: Colóquio/Letras. Lisboa, Portugal, n-38, julho, 1977.

A hora da estrela, de Clarice Lispector. In: Colóquio/Letras, Lisboa, Portugal, $\mathrm{n}^{\circ}$ 46, p.104-5, novembro, 1978.

Signantia Quasi Coelum/Signância quase céu, de Haroldo de Campos. In:

Colóquio/Letras. Lisboa, Portugal, n-59, p.87-9, janeiro, 1981.

- Canto em si e outros cantos, de Reynaldo Valinho Alvarez. In: Colóquio/Letras. Lisboa, Portugal, nº61, maio, 1981.

- La politique culturelle du governement brésilien. In: Bicéphale. Europe/Amerique Latine, Paris, França, nํㅜ 3, printemps, 1981.

. Haroldo Maranhão: uma microscopia da prosa. In: Colóquio/Letras. Lisboa, Portugal, $\mathrm{n}^{\mathrm{o}}$ 65, janeiro, 1982. 
Impressão de Viagem, de Heloísa Buarque de Holanda. In: Colóquio/Letras. Lisboa, Portugal, $n^{0}$ 68, julho, 1982.

Em liberdade, de Silviano Santiago. In: Colóquio/Letras. Lisboa, Portugal, $\mathrm{n}^{0}$ 69, setembro, 1982.

- Clarice Lispector ou o Naufrágio da introspecção. In: Colóquio/Letras. Lisboa, Portugal, n70, novembro, 1982.

. La guerre de la fin de monde. In: Magazine Littéraire. Paris, França, julho/agosto, 1983.

- Manuel Bandeira, Pré-Modernista, de Joaquim-francisco Coelho. In: Colóquio/Letras. Lisboa, Portugal, nํํ75, setembro, 1983.

. Grande Sertão: Veredas, uma abordagem filosófica - A figura da Narração ou as ciladas do tempo no romance de Guimarães ROSA, In: Bulletin des Études Portugaises et Brésiliennes, tome 44-45. Paris, França: ADPF, 1983-1985. (Editions Recherche sur lês Civilisations), p.389-404.

Anthropophagisme et surréalisme. In: SOBRAL, Luis de Moura. Surréalisme périphérique. Actes du colloque - Portugal, Québec, Amérique Latine: un surréalism périphérique? Montreal: Université de Montreal, 1984.

- Clarice Lispector Passion. In: Brasilianische Literatur, Materielen. Herausgegeben von Mechtild Strausfeld, Suhrkamp Taschenbuch, 1984.

. O Tetraneto del Rei (O Torto: suas idas e venidas), de Haroldo Maranhão. In: Colóquio/Letras. Lisboa, Portugal, nํ77, janeiro, 1984.

. Dedo-duro, de João Antônio. In: Colóquio/Letras. Lisboa, Portugal, nº79, maio, 1984.

- Le Roman Régionaliste Brésilienne. In: Braise, Revue Bimestrelle d'information et de Culture Brésilienne. Paris, França, maio-junho, 1984.

. A transgressão do texto. In: Colóquio/Letras. Lisboa, Portugal, 1984.

Wilson Martins, história da inteligência brasileira, vols. VI e VII. In:

Colóquio/Letras. Lisboa, Portugal, 1984. 
Introdução e nota filológica. In: LISPECTOR, Clarice. A paixão segundo G.H. Edição crítica. Paris, Association Archives [...]; Brasília: CNPQ, 1988. (p. XXIVXXXVIII).

. Antropologia e Antropofagia. In: JACKSON, K. David (org.). One Hundred Years of Invention: Oswald de Andrade and the Modern Tradition in Latin merican Literature. University of Texas at Austin, Austin, janeiro, 1990.

- Historiografia Literária no Brasil. In: The Cambridge History of Latin American Literature. Cambridge Universitt Press, Cambridge, United Kingdom, 1992.

. The literary historiography of Brazil. In: ECHEVERRÍA, Roberto González; PUPO-WALKER, Enrique. The Cambridge History of Latin American Literature. Cambridge: Cambridge University Press, 1996. 3 v., v.3, p. 11-46.

. La pasión de Clarice Lispector. In: Revista Anthropos - Clarice Lispector, La escritura del cuerpo y el silencio. Ecce homo, Extraordinario 2, 12 de julio de 1997.

. João Cabral: filosofia e poesia. In: Colóquio/Letras. Lisboa, Portugal, $\mathrm{n}^{\mathrm{os}}$ 157/158, julho-dezembro, 2000, p.37-44.

Textos Críticos, Prefácios e Introduções.

NUNES, Benedito. Considerações sobre a redução Sociológica de Guerrero Ramos. In: A Redução Sociológica (em apêndice II). Rio de Janeiro: Tempo Brasileiro, 1961, p.200-210.

- Poesia de Mário Faustino (organização e introdução crítica). Rio de Janeiro: Civilização Brasileira, 1966, p.3-35.

. Curso de Lógica e Filosofia da Ciência. Belém, FIPAM-NAEA, 1966.

. Curso de Kant a Heidegger. Belém: UFPA, 1972.

. Verbete Filosofia da Arte para Enciclopédia Brasileira Globo, edição de 1972.

Antropofagia ao alcance de todos. In: ANDRADE, Oswald de. Do Pau Brasil à Antropofagia e Utopias. Rio de Janeiro: Civilização Brasileira, 1972.

Antropofagia ao alcance de todos. In: ANDRADE, Oswald de. Do Pau Brasil à Antropofagia e Utopias. Obras Completas, vol. VI. São Paulo: Perspectiva: 1973, p.39-53. 
. Curso de Lógica e Filosofia das Ciências. Belém: UFPA, 1974.

. Curso de Ética. Belém: UFPA, 1975.

. Estética e correntes do Modernismo. In: Ávila, Affonso (org.). O modernismo. São Paulo: Perspectiva, 1975, p.39-53.

. O pensamento estético no Brasil. Campinas: UNICAMP, 1977.

. Organização e Introdução. In: Mário Faustino: Poesia-Experiência. São Paulo: Perspectiva, 1977, Coleção Debates, n. 136 , p.7-24.

Prefácio. In: ALBERGARIA, Consuelo. O “bruxo” da linguagem no Grande Sertão. Rio de Janeiro: Tempo Brasileiro, 1977, p.13-15.

. O pensamento estético no Brasil. In: CRIPPA, Adolfo (coord.) As idéias filosóficas no Brasil - parte II. São Paulo: Convívio, 1978, p.85-142.

. Curso de Estética e Poesia. Belém: UFPA, 1978.

A visão romântica. In: GUINSBURG, J. O Romantismo. São Paulo: Perspectiva: 1978, p.1-42.

. Diretrizes da Filosofia no Renascimento. In: FRANCO, Afonso Arinos de Melo e outros. O Renascimento. Rio de Janeiro: Agir, Museu Nacional de Belas Artes, 1978, p.136.

Interdisciplinariedade nas ciências humanas. In: Série Seminários e Debates. Belém, Universidade Federal do Pará, Núcleo de Altos Estudos Amazônicos, Setor de Pesquisa, 1978.

. Prolegômenos a uma Crítica da Razão Estética. In: LIMA, Luiz Costa. Mimesis e Modernidade - formas e sombras. Rio de Janeiro: Paz e Terra, 1980, p.11-8.

Apresentação. In: Maranhão, Haroldo. O tetraneto Del-rei. Rio de Janeiro: Livraria Francisco Alves Ed., 1982.

Jogo Marcado. In: MARTINS, Max e CARVALHO, Age. A fala entre parêntesis. Belém: PMB/SEMEC/Edições Grapho, 1982.

A matéria vertente. In: Seminário de ficção mineira III -De Guimarães Rosa a nossos dias. Belo Horizonte: Conselho Estadual de Cultura de Minas Gerais, 1983, p.9-39. 
. O universo filosófico e ideológico do barroco. In: Separata de Barroco 12. Belo Horizonte, 1983.

. Reflexões sobre o moderno romance brasileiro. In: Ensaios da Bienal Nestlé de Literatura. São Paulo: 1983.

. Verbete (em regime de colaboração permanente) para Grande Dicionário de Literatura Portuguesa e de Teoria Literária, sob orientação de João José Cochofel. Iniciativas Editoriais de Lisboa.

- Introduções a Marginália Platônica, Teeteto e Crátilo, Parmênides e A República, Diálogos, Platão. Coleção Amazônica (Série Farias Brito). Belém: Universidade Federal do Pará.

Literatura e filosofia. In: LIMA, Luiz Costa. Teoria da Literatura em suas fontes. vol.1. 2. ed. Rio de Janeiro: Francisco Alves, 1983, p.188-207.

. Literatura e Filosofia. Rio de Janeiro: Civilização Brasileira, 1983.

. Apresentação. In: O livro do seminário. Bienal Nestlé de Literatura Brasileira. São Paulo: LR Editores, 1983, p.43-70.

. Saber, poder; ensaios. São Paulo: Tempo Brasileiro, 1983.

. O amor na obra de Guimarães Rosa. In: COUTINHO, Eduardo F. (org.). Guimarães Rosa. Rio de Janeiro: Civilização Brasileira, 1983.

. O Moderno Romance Brasileiro. 1- Bienal Nestlé de Literatura, São Paulo, 1984.

A visão romântica. In: GUINSBURG, J. O romantismo. 2- ed. São Paulo: Perspectiva, 1985, p.51-74.

. A poesia de Mário Faustino. In: Poesia completa. São Paulo: Max Limonad, 1985, p.19-46.

. Apresentação. Os melhores poemas de Mário Faustino. Ed. Global, 1985.

- (Org.). Filosofia: textos escolhidos. Belém: Centro de Filosofia e Ciências Humanas, 1985. 1v.

. A obra poética e a crítica de Mário Faustino; com um adendo comemorativo sobre o poeta. Belém: Conselho Estadual de Cultura, 1986. 
O trabalho da interpretação e a figura do intérprete na literatura. IN: PROENÇA FILHO, Domício (org). Literatura Brasileira - ensaios, criação, interpretação e leitura do texto literário. Vol.II. São Paulo, Norte, 1986, p.73-80.

. Introdução ao fim. In: CHAVES, Albeniza. Tradição e modernidade em Mário Faustino. Belém: UFPA, 1986.

. A Paixão de Clarice Lispector. In: NOVAES, Adauto (org.). Os sentidos da paixão. São Paulo: Companhia das Letras/Funarte, 1987, p.269-81.

Apresentação. In: CHAVES, Ernani. Foucault e a psicanálise. Rio de Janeiro: Forense-Universitária, 1988, p.XI-XIII.

Apresentação. Os melhores poemas de Mário Faustino. 2a ed. São Paulo: Global, 1988.

. (coord.). Edição crítica. In: LISPECTOR, Clarice. A paixão segundo G.H. Florianópolis: Ed. da UFSC, 1988. (Coleção Artigos).

. Narrativa histórica e narrativa ficcional. In: Bento Prado Júnior, José Américo Pessanha, Luiz Felipe Baeta Neves e outros. Narrativa: ficção e história. Rio de Janeiro: Imago, 1988.

Nota crítica. In: MOREIRA, Eidorfe. Obras Reunidas. Belém: Conselho Estadual de Cultura/SEDUC/CEJUP, 1989.

Apresentação. In: TORRES FILHO, Rubens Rodrigues. Poros. São Paulo: Duas Cidades, 1989.

. Comentário à exposição "Pluralismo e Teoria Social”, de Luiz Felipe Baeta Neves. In: A INTERPRETAÇÃO — $2^{\circ}$ Colóquio/UERJ. Rio de Janeiro: Imago, 1990, p.77-99. - Antropofagia ao alcance de todos. In: ANDRADE, Oswald. A utopia antropofágica. São Paulo: Globo/Secretaria do Estado de Cultura de São Paulo, 1990. (p. XXIV-XXXVIII).

. O amor na obra de Guimarães Rosa. In: COUTINHO, Eduardo F. (org.). Guimarães Rosa. 2. ed. Rio de Janeiro: Civilização Brasileira, 1991. p.144-169.

. Que isto de método...In: FONTES, Joaquim Brasil. Eros, tecelão de mitos - a poesia de safo de Lesbos.. São Paulo: Estação Liberdade, 1991. 
Apresentação. In: BEUTTEN-MÜLLER, Alberto. Katatruz e outros poemas. São Paulo: Massao Ohno/Roswitha Kempf Editores, 1991.

. Apresentação. In: Maranhão, Haroldo. Memorial do fim: a morte de Machado de Assis. São Paulo: Marco Zero, 1991.

. Max Martins, Mestre-Aprendiz. In: Martins, Max. Não para consolar - poesia completa. Belém: Edições CEJUP, 1992.

- Tempo. In: JOBIM, José Luis (org.). Palavras da Crítica: tendências e conceitos no estudo da literatura. Rio de Janeiro: Imago, 1992, p.343-366.

. Experiências do tempo. In: NOVAES, Adauto (org.). Tempo e história. São Paulo: Companhia das Letras, 1992, p.131-140.

. “O trágico” In: Filosofia e política. nº 7 Porto Alegre: L \& PM, 1993.

. Evolução da poesia brasileira. Salvador: Fundação Casa Jorge Amado, 1993.

. Trinta anos depois. In: 30 anos - Semana Nacional de Poesia de Vanguarda -

1963/1993. Prefeitura de Belo Horizonte/Secretaria Municipal de Cultura. Belo Horizonte, 1993.

. A morte da arte em Hegel. In: DUARTE, Rodrigo A. de Paiva. Anais do Colóquio Nacional "Morte da arte, hoje”. Belo Horizonte: Laboratório de Estética da FAFICH/UFMG, 1993, p.9-33.

. Casa, praça, jardim e quintal. In: Separata Ciência \& Trópico. Recife, v. 22, n.2, p.253-264, julho-dezembro, 1994.

. O tempo dividido: Cosmos e História. In: NUNES, Benedito (org.). A crise do pensamento: ciclo de preleções. Belém: UFPA/Núcleo de Arte Fundação Rômulo Maiorana, 1994, p.123-154.

. O amor na obra de Guimarães Rosa. In: ROSA, João Guimarães. Ficção Completa. Rio de Janeiro: Nova Aguilar, 1994. v.1, p.112-141.

. Poética do pensamento. In: NOVAES, Adauto. Artepensamento. São Paulo: Companhia das Letras, 1994. p.389-409.

. ALENCAR, José. Iracema: lenda do Ceará. 28. ed. São Paulo: Ática, 1995.

. O “fragmento" da juventude. In: BOSI, Alfredo (org.). Leituras de poesia.

São Paulo: Ática, 1996, p.171-190. 
. Brio: ascese da linguagem. In: FROTA, Lélia Coelho. Brio. São Paulo: Sete Letras, 1996.

. Leitura filosófica de Guimarães Rosa. In: BARROS, Maria Heloísa Noronha. Miguilim e Manuelzão: viagem para o ser. Belo Horizonte: Gráfica Valci Editora, 1996.

. À margem do livro. In: MENDES, Armando Dias. A casa e suas raízes. Belém: Cejup, 1997.

. Prefácio. In: Fontes, Joaquim Brasil. A musa adolescente. São Paulo: Iluminuras, 1998.

- Heidegger e Aristóteles. In: Aristotelismo antiaristotelismo - Ensino de Filosofia. Belém: Ed. Agora da Ilha, 1999.

Apresentação. In: PESSANHA, Juliano Garcia. Sabedoria do nunca. São Paulo: Ateliê Editorial, 1999, p.13-6.

. Um triunfo Barroco na selva Amazônica. Os Tristes, Brutos Índios de Vieira ou um Missionário Aturdido. In: GUTIERREZ, Ângela et al. O território do Barroco no século XXI. N 18. Ouro Preto/Belo Horizonte: Instituto Cultural Flávio Gutierrez, 2000, p.23-9.

O nativismo de Paes Loureiro. In: PAES LOUREIRO, João Jesus de. Obras reunidas. Volume 1. São Paulo: Escrituras Editora, 2000.

. Prefácio. In: BUENO, Wilson. Meu tio Roseno, a cavalo. São Paulo: Ed. 34, 2000.

. Devoção à poesia. In: (org.). O amigo Chico: fazedor de poetas. Belém: SECULT, 2001.

. Francisco Paulo Mendes, para além da crítica literária. In: (org.). $O$ amigo Chico: fazedor de poetas. Belém: SECULT, 2001.

. MAROJA, Ângela; MARTINS, Max. Poesias reunidas de Max Martins. Belém, 2001.

Apresentação. In: DANTAS, Francisco José C. Coivara da memória. Lisboa: Estação Liberdade, 2001.

. Apresentação. In: CECIM, Vicente Franz. Ó Serdespanto. Lisboa: Íman, 2001. 
. A poesia de meu amigo Mário. In: BOAVENTURA, Maria Eugênia (org.). Mário Faustino - O homem e sua hora e outros poemas. São Paulo: Companhia das Letras, 2002, p.45-66.

. Que isto de método... In: Fontes, Joaquim Brasil. Eros - tecelão de mitos - a poesia de safo de Lesbos. $2^{\text {a }}$ ed. São Paulo: Iluminuras, 2003.

- A morte de Haroldo Maranhão. In: Confluências. Para lembrar Haroldo Maranhão. Belém: IAP, 2004.

A narração desarvorada. In: Cadernos de Literatura Brasileira - Clarice Lispector. São Paulo: Instituto Moreira Salles, 2004, p.292-301.

. Prefácio. In: GONÇALVES, Maria Magaly Trindade \& BELLODI, Zina C. Teoria da literatura “revisitada”. Rio de Janeiro: Ed. Vozes, 2005, p.9-10.

A poesia confluente [Eliot]. In: NOVAES, Adauto (org.). Poetas que pensaram o mundo. São Paulo: Companhia das Letras, 2005, p.269-89.

. Meu caminho na Crítica. In: Estudos Avançados, vol.19, n55, setembrodezembro de 2005, p.289-305.

- Dalcídio Jurandir: as oscilações de um ciclo romanesco. In: \& PERREIRA, Soraya R.R.; PERREIRA, Ruy P. (org.). Dalcídio Jurandir, romancista da amazônia Literatura \& Memória. Belém: SECULT; Rio de Janeiro: Fundação Casa de Rui Barbosa/Instituto Dalcídio Jurandir, 2006, p.245-51.

. O autor quase de cor: remomerações filosóficase literárias. In: Cadernos de Literatura Brasileira -Guimarães Rosa. São Paulo: Instituto Moreira Salles, 2006, p.236-244. - A resposta de Clarice. In: Clarice Lispector: a hora da estrela. [curadoria de Ferreira Gullar e Julia Peregrino] São Paulo: Museu da Língua Portuguesa, 2007, p.54/55;56/57;58/59. [Catálogo da exposição realizada em São Paulo, de 24 de abril a 2 de setembro de 2007].

Trabalhos em Eventos (colóquios, comunicações, conferências congressos, cursos, palestras, seminários) no Brasil

NUNES, Benedito. Participante do "IV Congresso Nacional de Escritores", como representante do Estado do Pará. Porto Alegre, 1950. 
As idéias do existencialismo. Conferência realizada na Faculdade de Direito. Belém: Universidade federal do Pará, 1951.

. Lógica formal. Conferência realizada na Faculdade de Direito. Belém: Universidade federal do Pará, 1952.

A atualidade de São Tomás de Aquino. Conferência realizada na Sede da Ação Católica. Belém, 1952.

A filosofia do Direito. Conferência realizada na Faculdade de Direito. Belém: Universidade federal do Pará, 1953.

A natureza da poesia. Conferência realizada na Academia Paraense de Letras. Belém, 1958.

. Participante convidado do "II Congresso de Crítica e História Literária.” Assis, São Paulo, 1961.

A arte de vanguarda. Conferência realizada na Faculdade de Direito. Belém: Universidade federal do Pará, 1963.

- Participação da I Semana de Poesia de Vanguarda, patrocinada pela Reitoria da Universidade de Minas Gerais. Belo Horizonte, 1963.

A estética do cinema. Conferência realizada na Faculdade de Arquitetura. Belém: Universidade federal do Pará, 1964.

O estilo gótico. Conferência realizada na Faculdade de Arquitetura. Belém: Universidade federal do Pará, 1965.

Estilos dramáticos. Conferência realizada na Faculdade de Arquitetura. Belém: Universidade federal do Pará, 1965.

. Conferência sobre "Teatro Brasileiro". Manaus: Secretaria de Cultura do Estado do Amazonas, 1965.

. Membro convidado do I Seminário de Literatura das Américas (I Bienal do Livro e da Literatura). São Paulo, 1970.

A filosofia contemporânea. Conferência realizada no Centro de Estudos Universitários. Belém: Universidade federal do Pará, 1971.

A filosofia atual. Conferência realizada no Centro de Estudos Universitários. Belém: Universidade federal do Pará, 1972. 
. Participante convidado dos festejos do Cinqüentenário da Semana de Arte Moderna. São Paulo, 1972.

. Correntes e Estética do Modernismo. Curso ministrado durante o VI Festival de Inverno da Universidade Federal de Minas Gerais. Ouro Preto, julho de 1972.

. Guimarães Rosa. Conferência realizada durante o VII Festival de Inverno da Universidade Federal de Minas Gerais. Ouro preto, julho de 1973.

. Conceito de estrutura e Forma Literária. Conferência realizada durante o

I Seminário Brasileiro de Crítica e Teoria da Literatura do Instituto de Letras da Universidade federal de Pernambuco. Pernambuco, 1973.

- Fernando pessoa. Conferência realizada durante o XV Seminário de

Verão da Associação de Estudos Portugueses Jordão Emerenciano. Pernambuco: Universidade federal de Pernambuco, 1973.

. Comentário a "Projeções do ideológico", de Luiz Costa Lima. I Encontro

Nacional de Professores de Literatura, promovido pelo Departamento de Letras e Artes da Pontifícia Universidade Católica do Rio de Janeiro. Rio e Janeiro: Cadernos da PUC $\mathrm{n}^{\circ} 26$, Série Letras e Artes, 1975, p.205-214.

. Guimarães Rosa. Conferência realizada durante o IX Festival de Inverno da Universidade Federal de Minas Gerais. Ouro preto, julho, 1975.

. Grande Sertão: Veredas. Conferência realizada durante o II Encontro Nacional de Professores de Literatura, promovido pelo departamento de Letras e Artes da Pontifícia Universidade Católica do Rio de Janeiro. Rio de Janeiro, 1975.

Literatura e Filosofia. Conferência realizada na Pontifícia Universidade Católica do rio de Janeiro. Rio de Janeiro, 1975.

. Avaliador dos resultados do Simpósio de Crítica Literária, realizado por ocasião do IX Encontro Nacional de Escritores. Brasília, 1975.

. Um conceito de Cultura. Aula Magna. Belém: Universidade Federal do Pará, 1975.

- Debatedor no II Encontro Nacional de Professores de Literatura, promovido pelo Departamento de Letras e artes da Pontifícia Universidade Católica do Rio de Janeiro. Rio de Janeiro, 1976. 
Diretrizes da Filosofia no Renascimento. Conferência realizada no Museu de Belas Artes. Rio de Janeiro, 1976.

. Filosofia da Arte e Educação Artística. Conferência realizada durante o Encontro Nacional de Educação Artística. Rio de Janeiro, 1976.

. O pensamento estético. Conferência realizada no Curso "Filosofia no Brasil. São Paulo, 1976.

Participante convidado do II Congresso Regional de Lingüística e Literatura. Pernambuco: Universidade Católica de Pernambuco, 1977.

A paixão de Clarice Lispector. Conferência realizada no Conselho Estadual de Cultura. Belém, 1978.

. Crítica e filosofia. Conferência realizada na Universidade de São Paulo.

São Paulo, 1979.

. Participação na "I Semana de Filosofia”, patrocinada pelo Colegiado do Curso de Filosofia. Belém: Universidade federal do Pará, 1979.

- A paixão de Clarice Lispector. Conferência realizada no diretório de Estudantes da Faculdade de Letras da Universidade de São Paulo. São Paulo, 1980.

. Participante da Mesa-Redonda sobre “Crítica e Poesia”. Campinas: UNICAMP, 1981.

O universo filosófico e ideológico do Barroco. Conferência realizada durante o I Congresso do Barroco no Brasil, promovido pelo Instituto estadual do Patrimônio Histórico e Artístico (IEPHA-MG). Ouro Preto, 1981.

. O moderno romance brasileiro. Conferência realizada durante Seminário na I Bienal Nestlé de Literatura. São Paulo, 1982.

- Comentador no Seminário de “Avaliação do Romance Brasileiro nos últimos 60 anos”, realizado durante a I Bienal Nestlé de Literatura. São Paulo, 1982.

Participante convidado do “III Simpósio Nacional de Artes Plásticas”. Recife, Pernambuco, outubro de 1982.

. Expositor do tema “Guimarães Rosa” no Seminário de “Ficção Mineira II”, promovido pelo Conselho Estadual de Cultura. Belo Horizonte, Minas Gerais, novembro de 1982. 
O poeta-crítico Mário Faustino. Conferência realizada durante a homenagem prestada a Mário Faustino e Torquato Neto pela Secretaria de Estado de Cultura do Piauí. Piauí, novembro de 1982.

. Dialética e reflexão estética. Painel apresentado no "I Seminário de Filosofia do Nordeste”. João Pessoa: Universidade Federal da Paraíba, 1983.

- Reavaliação heideggeriana de Marx. Conferência realizada no "I Seminário de Filosofia do Nordeste”. João pessoa: Universidade Federal da Paraíba, 1983. . Fundamentação da Estética e Ciências Humanas. Curso ministrado no Instituto de Filosofia da Universidade Federal do Rio de Janeiro. Rio de Janeiro, setembro de 1983.

- Personimagem. Conferência realizada no Seminário de "Literatura Portuguesa Contemporânea”. São Paulo: Universidade de Campinas, outubro de 1983.

A matéria vertente. c no Seminário de “Ficção Mineira', promovido pelo Conselho Estadual de Cultura de Minas Gerais. Belo Horizonte, novembro de 1983.

O ensino de filosofia. Palestra patrocinada pelo Departamento de Filosofia e Metodologia. Belém: Universidade federal do Pará, 1983.

- Hermenêutica e Fenomenologia e A moral dos Cadernos de Sartre. Seminário patrocinado pelo Departamento de Filosofia e Metodologia. Belém: Universidade federal do Pará, 1983.

Novas tecnologias da comunicação e a cultura. Conferência realizada no Seminário “Sociedade, Cultura e Tecnologia”, promovido pela Fundação João Pinheiro. Belo Horizonte, agosto de 1984.

A interpretação do texto literário. Conferência realizada no Seminário de “Literatura Brasileira” da II Bienal Nestlé de Literatura Brasileira. São Paulo, setembro de 1984.

Expositor da Mesa-Redonda "Crise e Estética”, realizada no "II Simpósio de Filosofia do Nordeste e IV Semana de Filosofia no Maranhão”. São Luís, Maranhão, outubro de 1984. 
. Cultura tecnológica emergente ou crise da cultura? Conferência realizada no “II Simpósio de Filosofia do Nordeste e IV Semana de Filosofia no Maranhão”. São Luís, Maranhão, outubro de 1984.

Participante da Mesa-Redonda sobre "Modernismo e o Surrealismo", com Maria Eugênia Boaventura e Vera Chalmers, sob o patrocínio da Aliança Francesa. São Paulo, novembro de 1984.

. Fundamentos da Estética Moderna. Curso ministrado na Universidade Federal do Rio de Janeiro. Rio de Janeiro, 1985.

. A obra poética e a crítica de Mario Faustino. Conferência realizada no Conselho Estadual de Cultura do Pará. Belém, 28 de maio de 1985.

Grande sertão: veredas - uma abordagem filosófica. Conferência realizada no “Seminário sobre Guimarães Rosa”. Departamento de Letras da Universidade de Brasília. Brasília, outubro de 1985.

Participante da Mesa-Redonda “O papel da Universidade na formação do professor de filosofia”, realizado no I Encontro Estadual de Professores de Filosofia promovido pela Associação Filosófica do Estado de São Paulo (AFESP) e Núcleo Regional da Sociedade de Estudos e Atividades Filosóficas (SEAF). Santos, São Paulo, 1985.

Participante da Mesa-Redonda "Surrealisme et Antropophagisme”, realizada durante a “Semana Surrealista da Aliança Francesa”. São Paulo: novembro de 1985. . Participante da Mesa-Redonda “Modernismo e Surrealismo”, realizada na Semana Surrealista do IEL”. São Paulo: Universidade de Campinas, 1985.

Participação do Simpósio “Tecnologia e Universidade”, organizado pelo MEC. Belém: Universidade federal do Pará, 1985.

. Palestrante do "Colóquio em Comunicação do Centenário da morte de Fernando Pessoa”, organizado pelo Núcleo de Estudos de Cultura de Expressão Portuguesa (NECEPO) e Departamento de Teoria Literária do IEL. São Paulo: Universidade de Campinas, 1985.

Participação do Painel “Democracia e Universidade”, realizado durante o Ciclo de Debates “A questão democrática - subsídios para a Constituinte Universitária” da V Semana de Ciências Sociais e I Encontro do Centro Socioeconômico. Belém: Universidade federal do Pará, 1986. 
Participação da Mesa-Redonda “Socialismo Francês”, organizada pela

ARNI. Belém: Universidade federal do Pará, 1986.

Ética e Teoria dos Valores. Palestra ministrada durante o Curso de Extensão sobre Temas Especiais de Filosofia Jurídica. Departamento de Propedêutica Jurídica e Direito Comercial. Belém: Universidade federal do Pará, 1986.

- Problemas Fundamentais da Estética. A Estética de Hegel.

Fenomenologia e Pensamento existencial em Heidegger e Poesia e Filosofia em Heidegger.

Palestras realizadas durante a Semana de Estudos do Centro de Filosofia e Ciências Humanas. Belém: Universidade federal do Pará, 1986.

A obra de Mário Faustino. Conferência realizada na Semana Mário Faustino. Teresina, Piauí: Fundação Cultural do Piauí, 1986.

A paixão de Clarice. Conferência realizada no Seminário “Os sentidos da paixão”. Rio de Janeiro, São Paulo, Brasília e Curitiba: FUNARTE, 1986.

. Participante da Mesa-Redonda “Arte e Modernidade”, realizada no “III Encontro Nacional de Filosofia. Associação Nacional de Pós-Graduação em Filosofia (ANPOF). São Paulo: Universidade de São Paulo, setembro de 1986.

Fundamentação da Estética e Ciências Humanas. Conferência realizada na “XIII Semana de Filosofia da Universidade de Brasília”. Brasília, outubro de 1986.

Filosofia e Memória. Comunicação apresentada na Mesa-Redonda “filosofia e Memória”, realizada no "I Congresso Internacional de Teoria da memória. Fórum de Ciência e Cultura. Rio de Janeiro: Universidade federal do Rio de Janeiro, setembro de 1987.

. Uma experiência do ensino de filosofia no $2^{\circ}$ Grau. Palestra ministrada durante a “XIV Semana de Filosofia da Universidade e Brasília”. Brasília, outubro de 1987. - Narrativa histórica e narrativa ficcional. Conferência realizada no Colóquio “A Narrativa: história e Ficção”. Instituto de Letras e Centro de Produção da Universidade Estadual do Rio de Janeiro. Rio de Janeiro, novembro de 1987.

. Filosofia hoje: posições e ilusões. Conferência realizada durante a III Semana de Filosofia do Departamento de Filosofia. Belém: Universidade federal do Pará, novembro de 1987. 
Psicanálise e arte. Mesa-redonda realizada no Encontro "Psicanálise e Arte”. Belém: Colégio Freudiano de Belém, junho de 1988.

. Participação do Ciclo de Conferências "Problemas da Filosofia Alemã Contemporânea”. Departamento de Filosofia. Belém: Universidade federal do Pará, setembro de 1988.

- Interpretação e Teoria Social. Conferência realizada no Colóquio “A interpretação”. Rio de Janeiro: Universidade Estadual do Rio de Janeiro, outubro de 1988.

. Temporalidade e Historicidade. Curso na Pós-Graduação em Filosofia. João Pessoa, Paraíba: Universidade Federal da Paraíba, 1988.

. Filosofia de Bachelard. Palestra ministrada no Curso de especialização para Bibliotecários de Instituições de Ensino (IES). Biblioteca Central. Belém: Universidade Federal do Pará, janeiro de 1989.

Arte e Filosofia em Heidegger. Conferência realizada durante a "XVI Semana de Filosofia”. Brasília: Universidade de Brasília, agosto de 1989.

A Revolução Francesa e a Filosofia. Conferência realizada na Academia Paraense de Letras e promovida pela Faculdade Estadual de Educação em comemoração ao “II Centenário da Revolução Francesa”. Belém, agosto de 1989.

Leituras de Machado de Assis. Conferência realizada durante o "I Encontro de Professores de Literatura Brasileira", sob o tema "Machado de Assis - texto e contexto". Rio de Janeiro: Faculdade de Letras da Universidade Federal do Rio de Janeiro, setembro de 1989.

Participação da Mesa-redonda "Freud e a Cultura", realizada durante o “Encontro com Freud”, por ocasião das comemorações do $50^{\circ}$ aniversário de morte de Freud. Belém, Colégio Freudiano de Belém, setembro de 1989.

. Participante do Seminário “Texto Memória”, quando do lançamento dos primeiros volumes da Coleção Arquivos (Mário de Andrade e Clarice Lispector). Santa Catarina: Universidade Federal de Santa Catarina, outubro de 1989.

A musa na filosofia. Conferência realizada durante o Simpósio Heidegger em comemoração ao centenário do nascimento de Martin Heidegger. Rio Grande do Sul: Universidad do Rio Grande do Sul, novembro de 1989. 
Anotações críticas do Curso "Sobre a Modernidade na Alemanha e no Brasil”, do Prof. Willi Bolle. Belém: Casa dos estudos germânicos, novembro de 1990.

Participação no debate “O conceito de Modernidade em Walter Benjamin”.

Belém: Casa de Estudos Germânicos, 1990.

Participante da Mesa-Redonda "Poesia Brasileira Contemporânea - A visão dos críticos”, realizada durante a $43^{\mathrm{a}}$ Reunião Anual da Sociedade Brasileira para o Progresso da Ciência. Rio de janeiro: Universidade federal do Rio de Janeiro, julho de 1991.

. No tempo do niilismo e Hermenêutica e poesia. Conferências realizadas na “Semana Heidegger” do Curso de Mestrado em Letras. Niterói, Rio de janeiro: Universidade Federal Fluminense, março de 1992.

A musa na filosofia. Palestra ministrada durante o Ciclo de Conferências “Evolução do Pensamento Filosófico e Científico”, no Curso de Biblioteconomia. Belém: Universidade Federal do Pará, maio de 1992.

- O riso modernista. Conferência realizada durante o Ciclo de palestras “Semana de Arte Moderna - 70 anos”. Belém: Casa da Linguagem da Fundação Curro Velho, maio de 1992.

. O tempo dividido: cosmo e história. Conferência realizada durante o Ciclo de Preleções “A Crise do Pensamento”, no Núcleo de Arte da UFPA. Belém: Universidade Federal do Pará, junho de 1993.

. A morte da arte em Hegel. In: Colóquio Nacional "Morte da arte, hoje”. Belo Horizonte, 1993.

O Princípio Responsabilidade de Hans Jonas: uma contribuição para a

bioética. Conferência realizada durante o Seminário "Filosofia e Ciência”, promovido pelo Centro Acadêmico de Filosofia. Belém: Universidade Federal do Pará, 7 de julho de 1994.

. Universidade e Regionalismo - Aula Inaugural do ano de 1999. In: Impresso da Universidade Federal do Pará, abril de 1999.

e FIGUEIREDO, Aldrin Moura de. Luzes e sombras do iluminismo paraense. Conferência realizada no Ciclo de Estudos “A Amazônia na época de Landi”, promovido pelo Museu do Estado do Pará, em setembro de 2000 e posteriormente proferida no "II Encontro Regional de História”, em novembro de 2000. 
. Autonomia em Preto e Branco (sobre Evaldo Coutinho). Palestra ministrada na $3^{\mathrm{a}}$ Feira Internacional do Livro de Pernambuco. Pernambuco: Centro de Convenções de Pernambuco, 21 de outubro de 2001.

. O Império da História. In: Seminário Landi e o Século XVIII na Amazônia. Belém, 2003, Anais Eletrônicos. In: www.landi.inf.br/anais.

Dalcídio Jurandir: as oscilações de um ciclo romanesco. Palestra ministrada na Fundação Casa de Rui Barbosa, quando da inauguração do Instituto Dalcídio Jurandir. Rio de Janeiro, julho de 2003.

. Estética da articulação: a palavra, condição da intersubjetividade. Palestra ministradaa no VI Colóquio Filosofia e Literatura na UNISINOS. Rio Grande do Sul, $1^{\circ}$ de outubro de 2003.

. Um conceito de cultura. Reimpressão da Palestra publicada em 1973. Belém: Conselho Estadual de Cultura, setembro de 2004.

. A linguagem em Heidegger. (Texto inédito) In: Colóquio Heidegger. São Paulo: Pontifícia Universidade Católica.. Dia 13 de outubro de 2004.

- A resposta de Clarice. In: III FLIP - Festa Literária Internacional de Parati. Parati, 07 de julho de 2005.

Do romance à crítica da razão dialética. (Texto inédito) Brasília: Centro Cultural Banco do Brasil. Projeto “Sartre - as razões da liberdade”. Palestra: Caminhos da filosofia: literatura e história. Dia 21 de setembro de 2005.

Do romance à crítica da razão dialética. (Texto inédito) São Paulo: Centro Cultural Banco do Brasil. Projeto "Sartre - as razões da liberdade”. Palestra: Os poderes da palavra: Filosofia, Literatura e Ética. Dia 05 de outubro de 2005.

. Heidegger e Sartre - em torno da História. (Texto inédito) In: Colóquio Heidegger. São Paulo: Pontifícia Universidade Católica.. Dia 7 de outubro de 2005.

- Guimarães Rosa quase de cor. São Paulo: Universidade de São Paulo. Evento: “Homenagens a Guimarães Rosa”. Dia 17 de maio de 2006. Guimarães Rosa quase de cor. (Texto inédito) Belém: X PAN Amazônica (Feira de livros). Dia 21 de setembro de 2006. 
Gênio, Mania e Folia. (Texto inédito) Belém: Estação da Docas. Dia 29 de junho de 2006.

. Belém de Max Martins. (Texto inédito) Belém: X PAN Amazônica (Feira de livros). Dia 17 de setembro de 2006.

- Eidorfe Moreira - concepção geográfica da vida. (Texto inédito)

Belém: X PAN Amazônica (Feira de livros). Dia 20 de setembro de 2006.

Meu caminho na crítica. Palestra de Abertura da Série Colóquio Rumos da Literatura - 2007-2008. São Paulo: Instituto Itaú Cultural. Dia 14 de março de 2007.

História da Literatura: Leitores de Homero. Curso de História da Literatura. Belém: Centro de Cultura e Formação Cristão (CCFC). Dias 26 e 27 de maio de 2007.

Trabalhos em Eventos (colóquios, comunicações, conferências congressos, cursos, palestras, seminários) no exterior

NUNES, Benedito. Política Cultural do Governo Brasileiro (Cultural Policy of the Brazilian Government). Comunicação apresentada no Seminário “O papel do Estado Brasileiro no Desenvolvimento Contemporâneo" ("The Tinker Conference on the Roles of the Brazilian state in Contemporary Development”). Texas, EUA: Universidade de Austin, novembro de 1980.

Mário de Andrade: as enfribaturas do Modernismo. Conferência realizada no Simpósio sobre "Poesia Brasileira Contemporânea e Tradução Poética”. The Institute of Latin American Studies e The Department of Spanish and Portuguese. Texas, EUA: Universidade de Austin, novembro de 1980.

Clarice Lispector ou O naufrágio da introspecção. Conferência realizada no Department of Spanish and Portuguese. EUA: Universidade de Stanford, novembro de 1980.

As Enfibraturas do Modernismo. Conferência realizada no Centre d'Etudes Portuguaises, Brésiliennes et de L’Afrique Lusophose. Rennes, França: Universidade de Haute Bretagne, 1981. 
Antropophagisme et Surrealisme. Conferência realizada durante o

“Colloque sur le Surréalisme”. Canadá: Universidade de Montreal, setembro de 1983.

. Participante do Seminário sobre Literatura Latino-Americana. Paris, França: Casa do México, 1983/84.

. Oswald and Cultural Cannibalism. Conferência realizada durante as

Comemorações do Centenário do Nascimento de Oswald de Andrade. Texas, EUA: Universidade de Austin, janeiro de 1990.

. Participante da Mesa-Redonda “Do Moderno ao Modernismo” por ocasião das Comemorações do Centenário do Nascimento de Oswald de Andrade. Texas, EUA: Universidade de Austin, janeiro de 1990.

Antropologia e Antropofagia. Conferência realizada durante as

Comemorações do Centenário do Nascimento de Oswald de Andrade. Texas, EUA: Universidade de Austin, janeiro de 1990.

- Os originais de Clarice Lispector. Conferência realizada durante o

Colóquio “New Perspectives on Clarice Lispector: Gender, Narrative, Post-Structuralism”. New Haven, EUA: Universidade Yale, março de 1990.

Clarice Lispector: A paixão segundo G.H. Conferência realizada soob o patrocínio do The Departement of Spanish and Portuguese e do The center for Latin American and Iberian Studies da Universidade Vanderbilt. Nashville, EUA, abril de 1990.

. Poesia do pensamento. Conferência realizada durante Homenagem a Haroldo de Campos. Salto Oriental, Uruguay: Centro Cultural Internacional, junho de 1991.

\section{$\underline{\text { Outros }}$}

NUNES, Benedito. Homenagem a Dom Quixote. Recital de Canto e Piano. Theatro da Paz. Festival de Ópera, 2005. Texto “Notas do Programa” em página da Internet. Belém, julho de 2005.

Entrevista. In: NOBRE, Marcos e REGO, José Marcio. Conversas com filósofos brasileiros. São Paulo: Ed.34, 2000, p.69-89. 
$\underline{\text { Fontes eletrônicas }}$

http:/master.prossiga.br/pacc/estudos_culturais/index.html

\section{$\underline{\text { Traduções }}$}

Crônica/Chronique de PERSE, Saint-John. Tradução por Benedito Nunes e Michel Riaudel. Belém: CEJUP, 1992.

Poema Baudelaire, de Rilke. In: Suplemento Belo Horizont. Belo Horizonte, julho de 1995, Secretaria do estado da Cultura de Minas Gerais. n 3, p.24.

\section{Distinções, Prêmios e Homenagens}

- $\quad$ Bolsa da Guggenheim Foundation, 1970.

- $\quad$ Prêmio Jabuti (Câmara Brasileira do Livro), 1987.

- $\quad$ Título de Professor Emérito da Universidade Federal do Pará, 1996.

- $\quad$ Prêmio Multicultural Estadão, 1998.

- $\quad$ Prêmio Ministério da Cultura/FUNARTE, 1999.

- $\quad$ Comenda Ordem do Cruzeiro do Sul, Ministério do Exterior, 2003.

- $\quad$ Ordem do Mérito Cultural, Minc, 2004.

- $\quad$ Prêmio APCA (pelo percurso e produção como crítico de arte), 2005. Cerimônia de entrega, 17 de maio de 2006.

\section{Sobre Benedito Nunes}

ANDRADE, Abrahão Costa. Filosofia e literatura. In: Angústia da concisão - ensaio de filosofia e crítica literária. São Paulo: Escrituras Editora, 2003.

ANDRADE, Andréa Costa de. Diálogos filosóficos com Benedito Nunes. Dissertação de mestrado. UFAM/AM, 2006.

BENEDICTUS. Encarte por ocasião da titulação de Benedito Nunes como Professor Emérito da Universidade federal do Pará. Belém, Pará, novembro de 1998. 
CASTRO, José Carlos. Benedito Nunes: 70 anos. O Liberal, O Cartaz, Belém, 19 dez. 1999, p. 12-13.

CASTRO, José Guilherme de Oliveira. Alguns aspectos da crítica literária de Benedito Nunes. Dissertação de mestrado.PUC/RS, 1976.

CHAVES, Ermani. Filosofia e Literatura em Benedito Nunes. O Liberal, O Cartaz, Belém, 16 mar. 2000, p. 5.

DIAS, Maurício Santana. No limite da transcendência. In: Folha de S.Paulo. São Paulo, Caderno Mais! O9 de março de 2003.

LEOPOLDO E SÍLVA, Franklin. O trabalho da hermenêutica. In: Folha de S.Paulo. São Paulo, Jornal de Resenhas, n 60, 11 de março de 2000, p.6.

LUCAS, Fábio. Clarice segundo Benedito Nunes. In: Crítica sem dogma. Belo Horizonte: Imprensa Oficial, 1983, p.47-51.

. Clarice Lispector (1973). In: Colóquio/Letras. Lisboa, Portugal, n² 24, p. 867, março, 1975.

MONTEIRO, Maria Neuza. A filosofia da arte para Benedito Nunes. Dissertação de mestrado. PUC/RJ, 1978.

NORDMANN, Jean-François. Benedito Nunes 1998: Crivo de papel. In: Natureza Humana: Revista Internacional de Filosofia e Práticas Psicoterápicas/ Grupo de Pesquisa em Filosofia e Práticas e Psicoterápicas do Programa de Estudos Pós-Graduados em Psicologia Clínica da PUC-SP. São Paulo, vol.1, n² 2, 1999.

PEREIRA, Nilo Carlos. Filosofia e ficção: o ser em o Drama da linguagem, de Benedito Nunes. Dissertação de mestrado. UFSC/SC, 2003.

OLIVEIRA, Fátima Aparecida Chaguri. Perspectivas e possibilidades de aproximação da filosofia e literatura no pensamento de Benedito Nunes. Dissertação de mestrado. UNICAMP/Campinas, 2003.

\section{Outros Autores}

ANDRADE, Abrahão Costa. Filosofia e literatura. In: Angústia da concisão - ensaio de filosofia e crítica literária. São Paulo: Escrituras Editora, 2003. 
ARARIPE JÚNIOR, Tristão de Alencar. Araripe Júnior: teoria, crítica e história literária. Seleção e apresentação de Alfredo Bosi. Rio de Janeiro: Livros Técnicos e Científicos; São Paulo: Editora da Universidade de São Paulo, 1978.

ARISTÓTELES. Tópicos. In: Os pensadores - vol I. Trad. Leonel Vallandro e Gerd Bornheim. São Paulo: Nova Cultural, 1991, p.2-152.

. Poética. In: Os pensadores - vol II. Trad. Eudoro de Souza. São Paulo: Nova Cultural, 1991a, p.197-260.

. Retórica. In: Obras Completas - vol. VIII, Tomo I. Trad. Manuel Alexandre Júnior, Paulo Farmhouse Alberto e Abel do Nascimento Pena. Lisboa: Centro de Filosofia da Universidade de Lisboa/Imprensa Nacional-Casa da Moeda, 2005.

ATHAYDE, Tristão. Teoria, crítica e história literária. Seleção e apresentação de Gilberto Mendonça Teles. Rio de Janeiro: Livros Técnicos e Científicos Editora/INL, 1980.

AUSTIN, J.L. How to do things with words. Cambridge: Harvard University Press, 1975.

ADORNO, Theodor. O ensaio como forma. In: Notas de literatura I. Trad. Jorge de Almeida. São Paulo: Duas Cidades/Ed.34, 2003.

. Teoria estética. Trad. Artur Morão. São Paulo: Martins Fontes, 1982. e HORKHEIMER, M. Dialética do esclarecimento. Trad. Guido de Almeida. Rio de Janeiro: Zahar, 1985.

BARBOSA, João Alexandre. Augusto Meyer ensaísta. In: Revista Cult - ano V, n54, janeiro de 2002, p.14-7.

A biblioteca imaginária. São Paulo: Ateliê Editorial, 1996.

A leitura do intervalo - ensaios de crítica. São Paulo:

Iluminuras, 1990.

. As Ilusões da modernidade. São Paulo: Perspectiva, 1986.

. Opus 60 - ensaios de crítica. São Paulo: Duas Cidades, 1980.

. A metáfora crítica. São Paulo: Perspectiva, 1974.

A tradição do impasse. Linguagem da crítica e crítica da linguagem em José Veríssimo. São Paulo: Ática, 1974. 
BARTHES, Roland. Crítica e verdade. $3^{\mathrm{a}}$ ed. Trad. Leyla Perrone-Moisés. São Paulo: Perspectiva, 2003.

. Da história ao real. In: O rumor da língua. Trad. Mario Laranjeira. São Paulo: Ed. Brasiliense, 1988, p.144-171. . Le degré zéro de l'éscriture. Paris: Du Seuil, 1972. . O grau zero da escritura. Trad. Anne Arnichand e Álvaro Lorencini. São Paulo : Cultrix, 1971. . Introdução à análise estruturalda narrativa. In: BARTHES, R. et al. Análise estrutural da narrativa. Trad. Maria Zélia B. Pinto. Rio de Janeiro: Vozes, 1971, p.18-58.

. Critique et vérité. Paris, Seuil, 1966.

Essais critiques. Paris, Seuil, 1964.

BEAINI, Thais. Heidegger: arte como cultivo do inaparente. São Paulo: Nova Stella - Edusp, 1986.

À escuta do silêncio. São Paulo: Cortez, 1981.

BENJAMIN, Walter. O conceito de crítica da arte no romantismo alemão. Trad. Márcio Seligmann-Silva. São Paulo: Iluminuras, 1993.

. Obras escolhidas. Vol. I. $3^{\mathrm{a}}$ ed. Trad. Sérgio Paulo Rouanet. São Paulo: Brasiliense, 1987.

Obras escolhidas. Vol. II. Trad. Rubens R.Torres Filho e José Carlos M. Barbosa. São Paulo: Brasiliense, 1987. . Origem do drama barroco alemão. Trad., apresentação e notas de Sérgio Paulo Rouanet. São Paulo: Brasiliense, 1984. . "Les affinités électives" de Goethe. In : Oeuvres I - Mythe et violence. Paris: Les Lettres Nouvelles, Denoël, 1971.

BENJAMIN, Andrew e OSBORNE, Peter (orgs.). A filosofia de Walter Benjamin: destruição e experiência. Trad. Maria Luiza X. de A. Borges. Rio de Janeiro: Jorge Zahar Editor, 1997.

BENVENISTE, E. Problèmes de linguistique générale. Paris: Gallimard, 1976. 
BERNARDINI, Aurora Fornoni. Formalismo Russo, uma revisitação. In: Revista Literatura e Sociedade. Departamento de Teoria Literária e Literatura Comparada/Faculdade de Filosofia, Letras e Ciências Humanas/Universidade de São Paulo $-\mathrm{N}^{\circ}$ 5. São Paulo: USP/FFLCH/DTLLC, 2000, p.30-42.

BORDINI, Maria da Glória. Fenomenologia e teoria literária. São Paulo: Edusp, 1990.

BORNHEIM, Gerd. As dimensões da crítica. In: MARTINS, Maria Helena (org.). Rumos da crítica. São Paulo: Editora SENAC/Itaú Cultural, 2000, p.33-45.

Gênese e metamorfose da crítica. In: DUARTE, Rodrigo A.P. (org.). Anais do colóquio nacional A morte da arte hoje. Belo Horizonte: Laboratório de Estética/FAFICH-UFMG,1993, p.46-55.

. Filosofia do romantismo. In: GUINSBURG, J. (org.). O Romantismo. São Paulo: Ed. Perspectiva, 1985, p.75-111.

BOSANQUET, Bernard. Historia de la estética. Buenos Aires: Nueva Visíon, 1970.

BOSI, Alfredo. Introdução. In: ARARIPE, Jr. Teoria, crítica e história literária. São Paulo: Edusp, 1978.

. Uma leitura de Vico. In: O ser e o tempo da poesia. São Paulo: Cultrix/ Editora da Universidade de São Paulo, 1977, p.193-220.

BRANDÃO, Roberto de Oliveira. A tradição sempre nova. São Paulo: Ática, 1976.

CAMPOS, Augusto de. O anticrítico. São Paulo: Companhia das Letras, 1986.

CAMPOS, Haroldo de. Metalinguagem \& outras metas. São Paulo: Perspectiva, 1992. A arte no horizonte do provável. São Paulo: Perspectiva, 1977. . Metalinguagem. Rio de Janeiro: Vozes, 1970.

CANDIDO, Antonio. O ato crítico. In: A educação pela noite \& outros ensaios. $3^{\mathrm{a}}$ ed. São Paulo: Ática, 2003, p.122-137.

. Literatura e Sociedade. ${ }^{\text {a }}$ ed. São Paulo: T. A . Queiroz Editor, 2000. . Tese e antítese - ensaios. 4. ed. São Paulo: T.A.Queiroz, 2000. . Vários escritos. São Paulo: Duas Cidades, 1995. . O discurso e a cidade. São Paulo: Duas Cidades, 1993. 
O método crítico de Sílvio Romero. São Paulo: Editora da Universidade de São Paulo, 1988.

Formação da Literatura Brasileira. Vol.I e Vol. II $6{ }^{\text {a }}$ ed. São Paulo:

Itatiaia, 1981.

Introdução. In: ROMERO, Sílvio. Teoria, crítica e história literária.

São Paulo: Edusp, 1978.

CARA, Salete de Almeida. A recepção crítica. São Paulo: Ática, 1983.

CARONE, Modesto. Metáfora e montagem. São Paulo: Perspectiva, 1974.

CASSIRER, Ernst. Linguagem e mito. $3^{\text {a }}$ ed. Trad. J. Guinsburg e Miriam Schnaiderman. São Paulo: Perspectiva, 1971.

CASTRO, Manuel Antônio de. Crítica e história literária. In: PORTELLA, Eduardo et al. Teoria literária. Biblioteca Tempo Universitário, n 42, Rio de Janeiro, 1991, p.19-39.

CHAUI, Marilena. Convite à filosofia. São Paulo: Ática, 2001.

CHAVES, Lilia Silvestre Mário Faustino: uma biografia. Belém: Secult; IAP; APL, 2004.

COELHO, Marcelo. Jornalismo e crítica. In: MARTINS, Maria Helena (org.). Rumos da crítica. São Paulo: Editora SENAC/Itaú Cultural, 2000, p.83-8.

COLERIDGE, S.T. Biographia literaria or biographical sketches of my literary life and opinions. London, New York: J.M.Dent, 1956.

COUTINHO, Afrânio. Introdução à literatura no Brasil. 13ª edição. Rio de Janeiro: Berthand Brasil S.A.,1988.

Da crítica e da nova crítica. Rio de Janeiro: Editora Civilização Brasileira S.A., 1957.

COSTA LIMA, Luiz. História. Fiç̧ão. Literatura. São Paulo: Companhia das Letras, 2006. Mimese e modernidade - Formas das sobras. $2^{\mathrm{a}}$ ed. São Paulo: Paz e Terra, 2003.

- Hermenêutica e abordagem literária. In: Teoria da Literatura em suas fontes. $1^{\circ}$ vol. $3^{\mathrm{a}}$ ed. Rio de Janeiro: Civilização Brasileira, 2002.

Mimeses: desafio ao pensamento. Rio de Janeiro: Civilização Brasileira, 2000. 
. Vida e mímesis. São Paulo: Ed.34, 1995.

. Limites da voz: Montaigne, Schlegel e Kafka. 2 vols. Rio de Janeiro:

Rocco, 1993.

. Metáfora: do ornato ao transtorno. In: A aguarrás do tempo - estudos sobre a narrativa. Rio de Janeiro: Rocco, 1989, p.123-186.

. O fingidor e o censor: no Ancien Régime, no Iluminismo e hoje. Rio de Janeiro: Forense Universitária, 1988.

- Questionamento da crítica literária. In: DIAS, Ângela et al. Função da crítica. Revista Tempo Brasileiro, n 60, Rio de Janeiro, janeiro-março de 1980, p.105-114.

CROCE, Benedetto. Breviário de estética e Aesthetica in nuce. Trad. Rodolfo Ilari Jr. São Paulo: Ática, 1997.

O que é vivo e o que é morto na filosofia de Hegel. Trad. Vittorino Nemésio. Portugal/Coimbra: Imprensa da Universidade, 1933.

DARTIGUES, André. O que é fenomenologia. Trad. Maria José J.G. de Almeida. São Paulo: Centauro Editora, s/d.

DERRIDA, Jacques. Gramatologia. $2^{\mathrm{a}}$ ed. Trad. Miriam Schnaiderman e Renato Janine Ribeiro. São Paulo: Perspectiva, 2004.

. A escritura e a diferença. $2^{\mathrm{a}}$ ed. Trad. Maria Beatriz M.N. da Silva. São Paulo: Perspectiva, 1995.

. La mythologie blanche. In: Marges de la philosophie. Paris: Éditions de Minuit, 1972.

A mitologia branca. In: Margens da filosofia. Trad. Joaquim Torres Costa e Antônio M. Magalhães. Portugual: Rés Editora Ltda, s/d. . L'écriture et la différence. Paris: Seuil, 1967.

DUBOI, J. et al. Rhétorique générale. Paris : Larousse, 1970.

- Retórica Geral. Trad. Carlos Felipe Moisés, Elenir de Barros e Dúlio Colombini. São Paulo: Ed. Cultrix, 1970.

EAGLETON, Terry. Teoria da literatura: uma introdução. $4^{\mathrm{a}}$ ed. Trad. Waltensir Dutra. São Paulo: Martins Fontes, 2001. 
ECO, Umberto. Interpretação e superinterpretação. Trad. MF. São Paulo: Martins Fontes, 2001.

. Os limites da interpretação. Trad. Pérola de Carvalho. São Paulo: Perspectiva, 2000.

A definição da arte. Trad. José Mendes Ferreira. Rio de Janeiro/Lisboa: Elfos/Edições 70, 1995.

Semiótica e filosofia da linguagm. Trad. Mariarosaria Fabris e José Luiz Fiorin. São Paulo: Ática, 1991.

FAUSTINO, Mário. Poesia-experiência. São Paulo: Perspectiva, 1977.

FILIPAK, Francisco. Teoria da metáfora. Curitiba: Livros HDV, 1983.

FLUSSER, Vilém. Língua e realidade. 3ª ed. São Paulo: Annablume, 2007.

FOUCAULT, Michel. Nietzsche, Freud, Marx. In: Cadernos de Teoria e Conhecimento I. Portugal: Ed. Rés Limitada, 1975.

Nietzsche, Freud, Marx. In: Cahiers de Royaumont. Paris: Les Editions de Minuit, 1967.

Les mots et les choses. Paris: Gallimard, 1966.

FRANCHETTI, Paulo. Crítica e saber universitário. In: SANTOS, Alcides Cardoso (org.). Estados da crítica. São Paulo: Ateliê Editorial/Editora da Universidade Federal do Paraná, 2006.

FREGE, G. Écrits logiques et philosophiques. Paris: Seuil, 1971.

GADAMER, Hans-G. Verdade e Método. $4^{\mathrm{a}}$ ed. Trad. Flávio Paulo Meurer. Rio de Janeiro: Vozes, 2002.

Verdade e método II. $2^{\text {a }}$ ed. Trad. Enio Paulo Giachini. Rio de Janeiro:

Vozes, 2004.

GAGNEBIN, Jeanne Marie. Do conceito de mímesis no pensamento de Adorno e Benjamin. In: Sete aulas sobre linguagem, memória e história. Rio de Janeiro: Imago, 1997, p.81-106.

GMEINER, Conceição Neves. A morada do ser - uma abordagem filosófica da linguagem na leitura de Martin Heidegger. São Paulo: Edições Loyola/Editora Leopoldianum,1998. 
HABERMAS, Jürgen. Mudança estrutural da esfera pública: investigações quanto a uma categoria da sociedade burguesa. Trad. Flávio R. Kothe. Rio de Janeiro: Tempo Brasileiro, 1984.

HANSEN, João Adolfo. Alegoria - construção e interpretação da metáfora. São Paulo: Atual, 1986.

HEGEL, G.W.F. Estética. In: Os pensadores. Trad. Orlando Vitorino. São Paulo: Nova Cultural, 1996.

HEIDEGGER, Martin. A caminho da linguagem. Trad. Márcia Sá Cavalcante Schuback. Petrópolis, Rio de Janeiro: Vozes; Bragança Paulista, São Paulo: Editora Universitária São Francisco, 2003.

Ser e Tempo. Parte I. $12^{a}$ ed. Trad. Márcia Sá Cavalcante Schuback. Petrópolis, Rio de Janeiro: Vozes, 2002.

- Ser e Tempo. Parte II. 12a ed. Trad. Márcia Sá Cavalcante Schuback. Petrópolis, Rio de Janeiro: Vozes, 2004.

Introdução à metafísica. Trad. Emmanuel Carneiro Leão. $4^{\mathrm{a}}$.ed. Rio de Janeiro: Tempo Brasileiro, 1999.

A origem da obra de arte. Trad. Maria da Coceição Costa. Lisboa: Edições 70, 1992.

. Conferências e escritos filosóficos. In: Os Pensadores. Trad. Ernildo Stein. São Paulo: Nova Cultural, 1991.

. Hölderlin y la esencia de la poesía. Barcelona : Antropos, 1989.

Sobre o humanismo. Trad. Emmanuel Carneiro Leão. Rio de Janeiro:

Tempo Brasileiro, 1967.

JAKOBSON, Roman. Lingüística e comunicação. Trad. Izidoro Blikstein e José Paulo Paes. São Paulo: Cultrix, 1975.

. Lingüística. Poética. Cinema. Trad. Haroldo de Campos et al. São Paulo: Perspectiva, 1970.

JAUSS, Hans Robert. A literatura como provocação (história da literatura como provocação literária). 2a ed. Trad. Tereza Cruz. Lisboa: Passagens, 2003. 
JAUSS, Hans Robert et al. A literatura e o leitor. Textos de Estética da Recepção. $2^{\text {a }}$ ed. Seleção, tradução e introdução de Luiz Costa Lima. Rio de Janeiro: Paz e Terra, 2001.

JOHNS, Per. Dionísio crucificado. Rio de Janeiro: Topbooks, 2005.

JOLLES, André. Formas simples. Trad. Álvaro Cabral. São Paulo: Cultrix, 1976.

KANT, Immanuel. Crítica da faculdade do juízo. 2a ed. Trad. Valério Rohden e António Marques. Rio de Janeiro: Forense-Universitária, 2005.

KOTHE, Flávio. O cânone cultural. Brasília: UNB, 1997. (org.). Walter Benjamin. Trad. Flávio Kothe. São Paulo: Ática, 1985. . Para ler Benjamin. Rio de Janeiro: Francisco Alves, 1976.

LAFETÁ, João Luiz. 1930: a crítica e o Modernismo. São Paulo: Ed. 34, 2000.

LEÃO, Emmanuel Carneiro. Aprendendo a pensar. Rio de Janeiro: Vozes, 1977.

LEENHARDT, Jacques. A literatura: uma entrada na história. Trad. Maria Luiza B. B. Vasconcelos. In: TURCHI, Maria Zaira e SILVA, Vera Maria Tietzmann. Leitor formado, leitor em formação - leitura literária em questão. São Paulo: Cultura Acadêmica/ANEP, 2006.

LEOPOLDO E SÍLVA, Franklin. O trabalho da hermenêutica. In: Jornal de Resenhas - Folha de S.Paulo. São Paulo, nº 60, 11 de março de 2000, p.6.

LOPES, Edward (1987). Metáfora - da retórica à semiótica. São Paulo: Atual, 1987.

LUCAS, Fábio. Fronteiras imaginárias. Rio de Janeiro: Cátedra/MEC, 1971.

LUCCHESI, Ivo. Walter Benjamin e as questões da arte sob o olhar da hipermodernidade. In: Revista Comum. Rio de Janeiro, vol.11, n²5, dezembro de 2005, p.57 a 91.

MAN, Paul de. Alegorias da leitura: Linguagem figurativa em Rousseau, Nietzsche, Rilke e Proust. Trad. Lenita R. Esteves. Rio de Janeiro: Imago, 1996.

The resistanca to theory. Minneapolos, Minnesota: University of Minnesota Press, 1989.

A resistência à teoria. Trad. Teresa Louro Pérez. Portugal: Edições 70, 1989.

A epistemologia da metáfora. In: SACKS, Sheldon (org.). Da metáfora. Trad. Thelma M. Nóbrega. São Paulo: Educ/Pontes, 1992, p.19-34. 
Blindness and insight: essays in the rhetoric of contemporary criticism. $2^{\mathrm{a}}$ ed. Minneapolis: University of Minnesota Press, 1988.

Allegories of reading: figural language in Rosseuau, Nietzsche, Rilke and Proust. New Haven: Yale University Press, 1979.

MARQUES, Oswaldino. Teoria da metáfora \& renscença da poesia americana. Rio de Janeiro: Livraria São José, 1956.

MARTINS, Wilson. A crítica literária no Brasil. Vols 1 e 2. $3^{\mathrm{a}}$ ed. Rio de Janeiro: Francisco Alves/Imprensa Oficial do Paraná, 2002.

MARTON, Scarlett. Nietzsche: a transvaloração dos valores. São Paulo: Ed. Moderna, 1993. Nietzsche - das forças cósmicas aos valores humanos. São Paulo:

Brasiliense, 1990.

MERLEAU-PONTY, Maurice. Textos selecionados. In: Os pensadores. Trad. Marilena de Souza Chauí. São Paulo: Nova Cultural, 1989.

Phénoménologie de la perception. Paris: Gallimard, 1945.

MEYER, Augusto. Textos críticos. Seleção e introdução de João Alexandre Barbosa. São Paulo: Perspectiva; Brasília: INL, Fundação Nacional Pró-Memória, 1986.

MOISÉS, Massaud. Dicionário de termos literários. São Paulo: Cultrix, 1974.

MONTEIRO, Adolfo Casais. Clareza e mistério da crítica. Rio de Janeiro: Fundo de Cultura, 1961.

NASCIMENTO, Evando. Literatura e filosofia: ensaio de reflexão. In: NASCIMENTO, Evando \& OLIVEIRA, Maria Clara Castellões de (orgs.). Literatura e filosofia: diálogos. Juiz de Fora: UFJF/ São Paulo: Imprensa Oficial do Estado de São Paulo, 2004.

. Derrida e a literatura. Niterói: EDUFF, 1999.

NIETZSCHE, Friedrich. Obras incompletas. In: Os pensadores. Vols. I e II. $5^{\mathrm{a}}$ ed. Trad. Rubens Rodrigues Torres. São Paulo: Nova Cultural, 1991.

. O livro do filófoso. Trad. Ana Lobo. Introd. Rosa Maria Branco.

Porto: Rés, 1984.

NORDMANN, Jean-François. Benedito Nunes 1998: Crivo de papel. In: Natureza Humana: Revista Internacional de Filosofia e Práticas Psicoterápicas/ Grupo de Pesquisa em Filosofia e 
Práticas e Psicoterápicas do Programa de Estudos Pós-Graduados em Psicologia Clínica da PUC-SP. São Paulo, vol.1, nº 2, 1999.

NUNES, Benedito ${ }^{89}$.

. \& HATOUM, Milton. Crônica de duas cidades: Belém e Manaus. Belém, Ed. Secult, 2006.

. Meu caminho na Crítica. In: Estudos Avançados, vol.19, n55, setembrodezembro de 2005, p.289-305.

- A poesia confluente [Eliot]. In: NOVAES, Adauto (org.). Poetas que pensaram o mundo. São Paulo: Companhia das Letras, 2005a, p.269-89.

A filosofia contemporânea. Edição Revista e Atualizada. Belém, EDUFFA, 2004.

Dalcídio Jurandir: as oscilações de um ciclo romanesco. In: Asas da Palavra

- Revista do Curso de Letras - Centro de Ciências Humanas e Educação - UNAMA Universidade da Amazônia - vol. 8, n-17, p.15-21, junho, 2004a.

- A narração desarvorada. In: Cadernos de Literatura Brasileira - Clarice Lispector. São Paulo: Instituto Moreira Salles, 2004b, p.292-301.

Physis Natura - Heidegger e Merleau-Ponty. In: Natureza Humana: Revista Internacional de Filosofia e Práticas Psicoterápicas/ Grupo de Pesquisa em Filosofia e Práticas e Psicoterápicas do Programa de Estudos Pós-Graduados em Psicologia Clínica da PUC-SP. São Paulo, vol.6, nำ julho-dezembro, 2004c, p.271-287.

. Um conceito de cultura. Reimpressão da Palestra publicada em1973. Belém: Conselho Estadual de Cultura, setembro de 2004d.

. Que isto de método... In: Fontes, Joaquim Brasil. Eros - tecelão de mitos - a poesia de safo de Lesbos. $2^{\text {a }}$ ed. São Paulo: Iluminuras, 2003.

. Heidegger e Ser e Tempo. Rio de Janeiro: Zahar Editora, 2002.

. Literatura e filosofia. In: LIMA, Luiz Costa. Teoria da Literatura em suas fontes. vol.1. 3a . ed. Rio de Janeiro: Civilização Brasileira, 2002a, p.199-219.

\footnotetext{
${ }^{89}$ Textos citados no corpo do trabalho.
} 
A poesia de meu amigo Mário. In: BOAVENTURA, Maria Eugênia (org.). Mário Faustino - O homem e sua hora e outros poemas. São Paulo: Companhia das Letras, 2002b, p.45-66.

. Max Martins, Mestre-Aprendiz. In: Asas da Palavra - Revista do Curso de Letras - Centro de Ciências Humanas e Educação - UNAMA - Universidade da Amazônia vol. 5, $\mathrm{n}^{\mathrm{o}}$ 11, p.13-35, julho, 2002c.

. Drummond, poeta anglo-francês. In: Asas da Palavra - Revista do Curso de Letras - Centro de Ciências Humanas e Educação - UNAMA - Universidade da Amazônia vol. 6, $\mathrm{n}^{-}$14, dezembro, 2002d, p.31-6.

. Carlos Drummond: a morte absoluta. In: Revista da Biblioteca Mário de Andrade - Carlos Drummond de Andrade - 100 anos. São Paulo, vols. 60/61, p.141 janeirodezembro, 2002/2003.

. Crítica literária no Brasil, ontem e hoje. In: MARTINS, Maria Helena (org.). Rumos da crítica. São Paulo: Editora SENAC/Itaú Cultural, 2000, p.51-79.

Entrevista. In: NOBRE, Marcos e REGO, José Marcio. Conversas com filósofos brasileiros. São Paulo: Ed.34, 2000a, p.69-89.

. Dois ensaios e duas lembranças. Belém: SECULT/UNAMA, $2000 \mathrm{~b}$.

. O Nietzsche de Heidegger. Rio de Janeiro: Pazulin, 2000c. (Coleção Ágora)

- Heidegger e a poesia. In: Natureza Humana: Revista Internacional de Filosofia e Práticas Psicoterápicas/ Grupo de Pesquisa em Filosofia e Práticas e Psicoterápicas do Programa de Estudos Pós-Graduados em Psicologia Clínica da PUC-SP. São Paulo, vol. 2, $\mathrm{n}^{-}$1, 2000d, p.103-127.

. Um triunfo Barroco na selva Amazônica. Os Tristes, Brutos Índios de Vieira ou um Missionário Aturdido. In: GUTIERREZ, Ângela et al. O território do Barroco no século XXI. N 18. Ouro Preto/Belo Horizonte: Instituto Cultural Flávio Gutierrez, 2000e, p.23-9.

. João Cabral: Filosofia e poesia. In: Revista Colóquio Letras. Nº 157/158, jul/dez de $2000 f$.

. Dois mestres e uma só lembrança. In: Revista Cult. Pará, vol. 14, nº 1, janeiro, 2003. 
. Hermenêutica e poesia - o pensamento poético. Belo Horizonte: Ed. UFMG, 1999.

. Ocaso da literatura ou falência da crítica? In: Revista Língua e Literatura. São Paulo, USP - Departamento de Letras, nº 24, 1999a, p.11-21.

. Universidade e Regionalismo - Aula Inaugural do ano de 1999. In: Impresso da Universidade Federal do Pará, 1999b.

Apresentação. In: PESSANHA, Juliano Garcia. Sabedoria do nunca. São Paulo: Ateliê Editorial, 1999c, p.13-6.

. Crivo de papel. São Paulo: Ática, 1998. (Série temas, v. 67. Filosofia e Literatura)

. O mito em Grande Sertão: Veredas. In: Scripta - Revista do Programa de PósGraduação em Letras e do Centro de Estudos Luso-afro-brasileiros da PUC/Minas. Belo Horizonte, vol. 2, $\mathrm{n}^{-}$3, p.33-40, $2^{\circ}$ sem., $1998 \mathrm{a}$.

- Os destroços da introspecção. In: ZILBERMAN, Regina et al. Clarice Lispector: a narração do indizível. Porto Alegre: Artes e Ofícios/Edipuc/Instituto Cultural Judaico Marc Chagall, 1998b, p.35-48.

. O tempo na narrativa. 2. ed. São Paulo: Ática, 1995.

. Casa, praça, jardim e quintal. In: Separata Ciência \& Trópico. Recife, v. 22, n.2, p.253-264, julho-dezembro, 1994.

. No tempo do niilismo e outros ensaios. São Paulo: Ática, 1993. (Série Temas, 35)

A morte da arte em Hegel. In: DUARTE, Rodrigo A.P. (org.). Anais do colóquio nacional A morte da arte hoje. Belo Horizonte: Laboratório de Estética/FAFICHUFMG,1993a, p.9-33.

. Passagem para o poético - filosofia e poesia em Heidegger. 2. ed. São Paulo: Ática, 1992. (Ensaios, 122)

- Introdução à filosofia da arte. $2^{\mathrm{a}}$ ed. São Paulo: Ática, 1989. (Série Fundamentos, 38).

. A Paixão de Clarice Lispector. In: NOVAES, Adauto (org.). Os sentidos da paixão. São Paulo: Companhia das Letras/Funarte, 1987, p.269-81. 
O trabalho da interpretação e a figura do intérprete na literatura. IN: PROENÇA FILHO, Domício (org). Literatura Brasileira - ensaios, criação, interpretação e leitura do texto literário. Vol.II. São Paulo, Norte, 1986, p.73-80.

- A obra poética e a crítica de Mário Faustino; com um adendo comemorativo sobre o poeta. Belém: Conselho Estadual de Cultura, 1986a.

A visão romântica. In: GUINSBURG, J. O romantismo. 2- ed. São Paulo: Perspectiva, 1985, p.51-74.

. Oswald Canibal. São Paulo: Perspectiva, 1979. (Elos, 26)

. O pensamento estético no Brasil. In: CRIPPA, Adolfo (coord.) As idéias filosóficas no Brasil - parte II. São Paulo: Convívio, 1978, p.85-141.

. A paixão de Clarice Lispector. Conferência realizada no Conselho Estadual de Cultura. Belém, 1978a.

. Diretrizes da Filosofia no Renascimento. In: FRANCO, Afonso Arinos de Melo e outros. O Renascimento. Rio de Janeiro: Agir, Museu Nacional de Belas Artes, 1978b, p.136.

Estética e correntes do Modernismo. In: Ávila, Affonso (org.). O modernismo. São Paulo: Perspectiva, 1975, p.39-53.

. Comentário a "Projeções do ideológico", de Luiz Costa Lima. I Encontro Nacional de Professores de Literatura, promovido pelo Departamento de Letras e Artes da Pontifícia Universidade Católica do Rio de Janeiro. Rio e Janeiro: Cadernos da PUC $\mathrm{n}^{\circ}$ 26, Série Letras e Artes, 1975a, p.205-214.

. Um conceito de Cultura. Aula Magna. Belém: Universidade Federal do Pará, 1975b.

. O dorso do tigre. $2^{\text {a }}$ ed. São Paulo: Perspectiva, 1976. (Coleção debates)

- Educação Artística e Filosofia da Arte. Conferência realizada durante o Encontro Nacional de Educação Artística. Rio de Janeiro, 1976a.

. Estética e correntes do Modernismo. In: Ávila, Affonso (org.). O modernismo. São Paulo: Perspectiva, 1975, p.39-53.

. Comentário a As projeções do ideológico. In: Caderno da PUC. I Encontro Nacional de Professores de Literatura, Rio de Janeiro, nº-26, 1975a, p.205-213. 
. João Cabral de Melo Neto. $2^{\text {a }}$ ed. Rio de Janeiro: Vozes, 1974. (Coleção Poetas Modernos do Brasil, vol. 1.)

Poesia e filosofia na obra de Fernando Pessoa. In: Revista Colóquio Letras. $\mathrm{N}^{\circ} 20$, julho de 1974a.

. Farias Brito - trechos escolhidos. Rio de Janeiro: Agir, 1967. (Coleção Nossos Clássicos, vol. 92.)

NUNES, Jordão Horta. As teorias da metáfora e o interacionismosimbólico: uma reconstrução metodológica. São Paulo: USP - Tese de doutorado, 2000.

OLIVEIRA, Valdevino Soares. Metáfora. In: Poesia e pintura - um diálogo em três dimensões. São Paulo: Ed. UNESP, 1999, p.117-158.

PALMER, Richard. Hermenêutica. Trad. Maria Luísa Ribeiro. Lisboa: Edições, 70, 2006.

PERNIOLA, Mario. Expansão e fragmentação do horizonte estético. In: Revista Diacrítica. Série Filosofia e Cultura, n 20/2. Trad. Vítor Moura. Braga: Universidade do Minho - Centro de Estudos Humanísticos, 2006, p.107-118.

- A estética do século XX. Trad. Teresa Antunes Cardoso. Lisboa:

Estampa, 1998.

PERRONE-MOISÉS, Leyla. Texto. Crítica.Escritura. São Paulo: Martins Fontes, 2005.

. Que fim levou a crítica literária? In: Inútil poesia. São Paulo: Companhia das Letras, 2000, p.335-344.

. Altas literaturas. São Paulo: Companhia das Letras, 1998.

. Situação crítica. In: Flores da escrivaninha. São Paulo: Companhia das Letras, 1990, p. 84-90.

Falência da crítica. São Paulo: Perspectiva, 1973.

PLATÃO. Fedro. Trad. e notas de Pinharanda Gomes. Portugal: Guimarães editores, Ltda, 1989.

PLEBE, Armando. Breve história da retórica antiga. Trad. Gilda N.M. de Barros. São Paulo: EPU: Ed. da Universidadede São Paulo, 1978.

PORTELLA, Eduardo. Teoria da comunicação literária. Rio de Janeiro: Tempo Brasileiro, 1976. 
Fundamento da investigação literária. Rio de Janeiro: Tempo

Brasileiro, 1974.

POUND, Erza. ABC of reading. London: Faber and Faber, 1961.

RAMOS, Maria Luiza. Fenomenologia da obra literária. Rio de Janeiro: Forense, 1969.

RICOEUR, Paul. Teoria da Interpretação. O discurso e o excesso de significação. Trad. Artur Morão. Lisboa, Edições 70, 2000.

. Interpretação e ideologias. Trad. Hilton Japiassu. Rio de Janeiro: Francisco

Alves, 1990.

. Uma retomada da Poética de Aristóteles. In: Leituras 2 - a região dos filósofos. Trad. Marcelo Perine e Nicolas N. Campanário. São Paulo: Ed. Loyola, 1996. Du texte à l' action: essais d'herméneutique II. Paris: Seuil,1986. . Temps et récit. 3 vol. Paris : Éditions du Seuil, 1983. Métaphore vive. Paris: Ed. du Seuil, 1975.

ROGER, Jérôme. A crítica literária. Trad. Rejane Janowitzer. Rio de Janeiro: DIFEL, 2002. ROSA, João Guimarães. Grande Sertão: veredas. Rio de Janeiro: Nova Fronteira, 1986. SANTAELLA, Lúcia. Qualidade metafórica. In: Matrizes da linguagem e pensamento sonora, visual, verbal. São Paulo: Iluminuras, 2001, p.303-305.

\& NÖTH, Winfried. Imagem - cognição, semiótica, mídia. São Paulo:

Iluminuras, 1998.

SANTIAGO, Silviano. Uma literatura nos trópicos. 2.ed. Rio de Janeiro: Rocco, 2000. (supervisão geral). Glossário de Derrida. Rio de Janeiro: Francisco Alves, 1976.

SANTOS, Alcides Cardoso (org.). Estados da crítica. São Paulo: Ateliê Editorial/Editora da Universidade Federal do Paraná, 2006.

SARTRE, Jean-Paul. Que é a literatura? 2 ${ }^{\mathrm{a}}$ ed. Trad. Carlos Felipe Moisés. São Paulo: Ática, 1993.

. Textos selecionados. In: Os pensadores. Trad.Rita C. Guedes, Luiz Roberto Sallinas Forte, Bento Prado Júnior. São Paulo: Nova Cultural, 1987. 
. L’imaginaire. Paris: Gallimard, 1986.

. Qu’ est-ce que la littérature ? Paris : Gallimard, 1985.

. La nausée. Paris; Gallimard, 1948.

SCHNAIDERMAN, Boris. João Ribeiro Atual. In: Revista do IEB, n ${ }^{\circ}$. São Paulo: Instituto de Estudos Brasileiros da Universidade de São Paulo, 1971.

SEARLE, J.R. Speech-acts, an essay in the philosophy of language. Cambridge:Cambridge V.P., 1970.

STEIN, Ernildo. A destruição da Estética como conseqüência da destruição da metafísica. In: DUARTE, Rodrigo A.P. (org.). Anais do colóquio nacional A morte da arte hoje. Belo Horizonte: Laboratório de Estética/FAFICH-UFMG,1993, p.34-45.

SÜSSEKIND, Flora. Rodapés, tratados e ensaios. In: Papéis colados. 2.ed. Rio de Janeiro: Editora UFRJ, 2002.

TADIÉ, Jean-Yves. A crítica literária no século XX. Trad. Wilma Freitas R. de Carvalho. Rio de Janeiro: Ed. Bertrand Brasil S. A.,1992.

TELES, Gilberto Mendonça. Introdução à crítica literária. In: In: DIAS, Ângela et al. Função da crítica. Revista Tempo Brasileiro, n 60, Rio de Janeiro, janeiro-março de 1980, p.23-51.

TINIANOV, Iuri. O problema da linguagem poética II - o sentido da palavra poética. Trad. Maria José Azevedo Pereira e Caterina Barone. Rio de Janeiro: Tempo Brasileiro, 1975.

VALÉRY, Paul. Variedades. Org. e introd. João Alexandre Barbosa. Trad. Maiza M. Siqueira. São Paulo: Iluminuras, 1999.

VALLEJO, Américo \& MAGALHÃES, Lígia C. Metáfora. In: Lacan: operadores da leitura. São Paulo: Perspectiva, 1991, p.83-91.

VATTIMO, Gianni. La fine della modernità. Italy: Garzanti Editore, 1999.

A filosofia e o declínio no Ocidente. In: MARTINS, Francisco M. e SILVA, Juremir Machado da (orgs.). Para navegar no século 21: tecnologias do imaginário e cibercultura. Porto Alegre: Sulina/Edipucrs, 2000, p.55-70.

WELLEK, René \& WARREN, Austin. Teoria da literatura e metodologia dos estudos literários. Trad. Luis Carlos Borges. São Paulo: Martins Fontes, 2003. 
WELLBER, David. New retórica e desconstrução. Luiz Costa Lima (org). Rio de Janeiro: Ed. UFRJ, 1990. 